ORNL/TM-2014/317

Weatherization Beyond the Numbers: Case Studies of Fifteen High-Performing Weatherization Agencies - Conducted May 2011 through July 2012

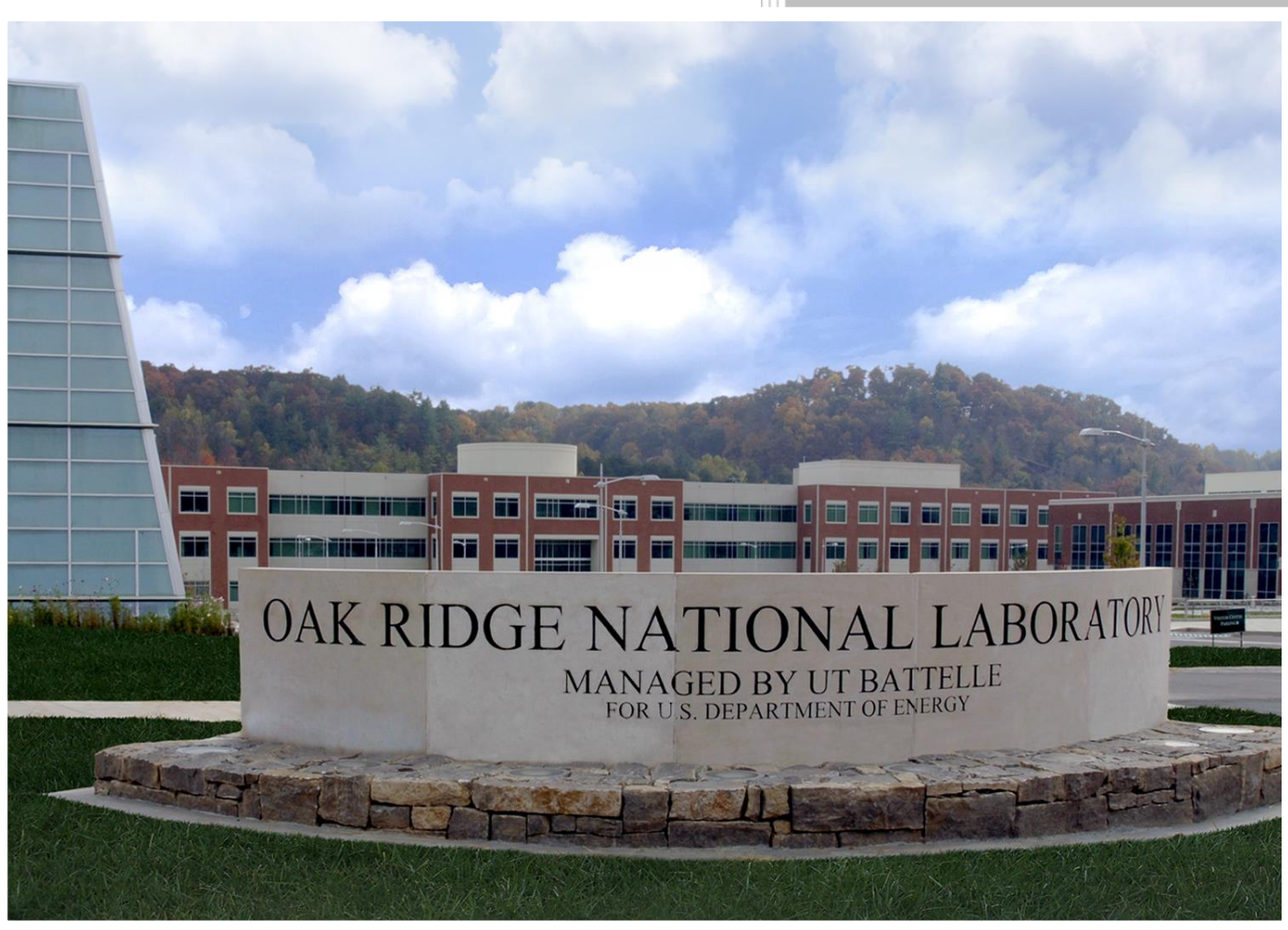

Bruce Tonn Erin Rose Beth Hawkins

September 2014 


\section{DOCUMENT AVAILABILITY}

Reports produced after January 1, 1996, are generally available free via US Department of Energy (DOE) SciTech Connect.

Website http://www.osti.gov/scitech/

Reports produced before January 1, 1996, may be purchased by members of the public from the following source:

National Technical Information Service

5285 Port Royal Road

Springfield, VA 22161

Telephone 703-605-6000 (1-800-553-6847)

TDD 703-487-4639

Fax 703-605-6900

E-mail info@ntis.gov

Website http://www.ntis.gov/help/ordermethods.aspx

Reports are available to DOE employees, DOE contractors, Energy Technology Data Exchange representatives, and International Nuclear Information System representatives from the following source:

Office of Scientific and Technical Information

PO Box 62

Oak Ridge, TN 37831

Telephone 865-576-8401

Fax 865-576-5728

E-mail reports@osti.gov

Website http://www.osti.gov/contact.html

This report was prepared as an account of work sponsored by an agency of the United States Government. Neither the United States Government nor any agency thereof, nor any of their employees, makes any warranty, express or implied, or assumes any legal liability or responsibility for the accuracy, completeness, or usefulness of any information, apparatus, product, or process disclosed, or represents that its use would not infringe privately owned rights. Reference herein to any specific commercial product, process, or service by trade name, trademark, manufacturer, or otherwise, does not necessarily constitute or imply its endorsement, recommendation, or favoring by the United States Government or any agency thereof. The views and opinions of authors expressed herein do not necessarily state or reflect those of the United States Government or any agency thereof. 
Environmental Sciences Division

\title{
WEATHERIZATION BEYOND THE NUMBERS: CASE STUDIES OF FIFTEEN HIGH-PERFORMING WEATHERIZATION AGENCIES - CONDUCTED MAY 2011 THROUGH JULY 2012
}

\author{
Bruce Tonn \\ Erin Rose \\ Beth Hawkins
}

September 2014

\author{
Prepared by \\ OAK RIDGE NATIONAL LABORATORY \\ Oak Ridge, Tennessee 37831-6283 \\ managed by \\ UT-BATTELLE, LLC \\ for the \\ US DEPARTMENT OF ENERGY \\ under contract DE-AC05-00OR22725
}





\section{CONTENTS}

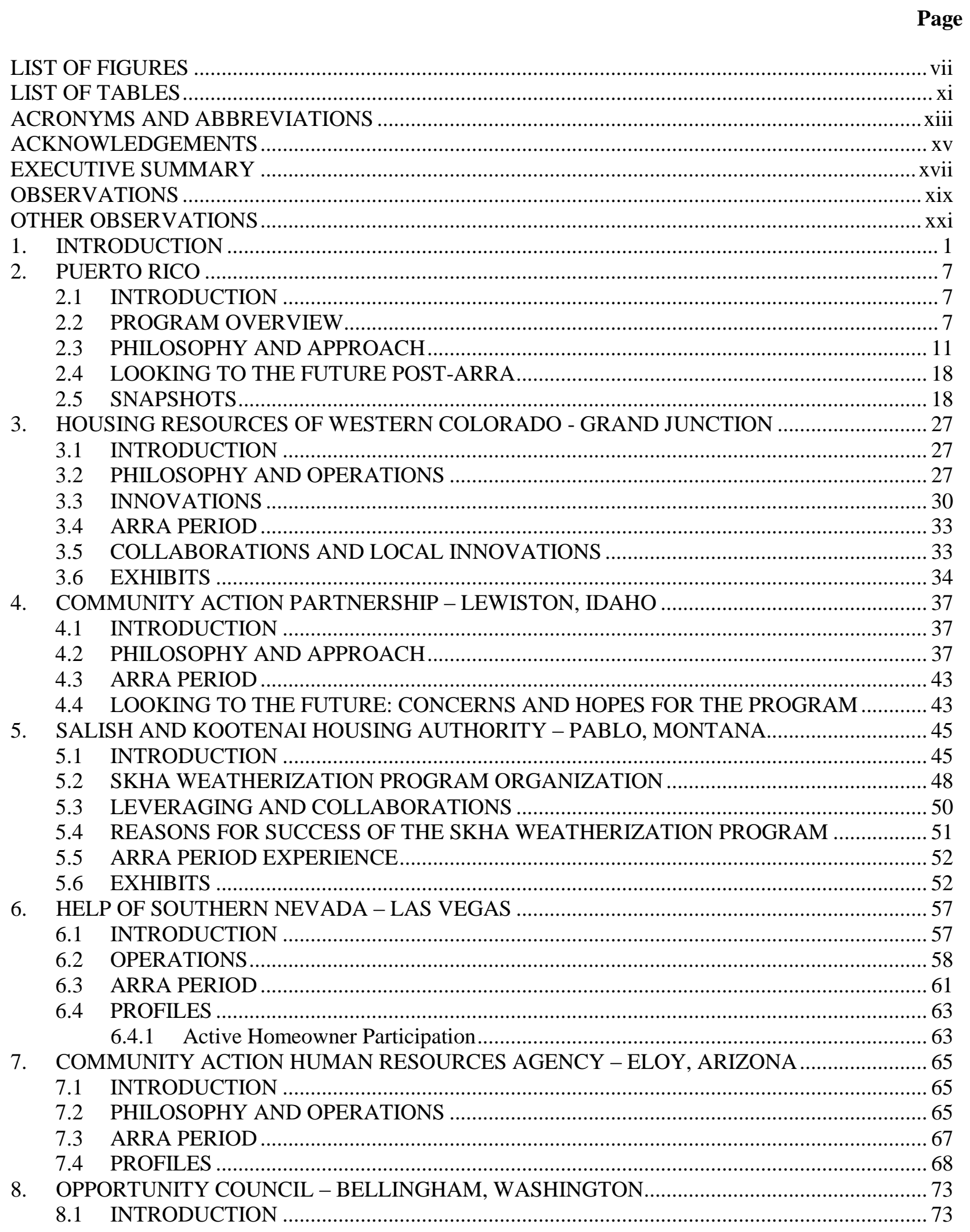




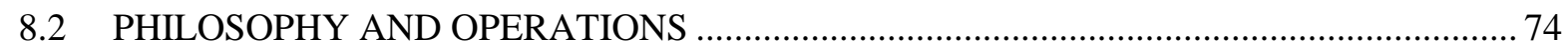

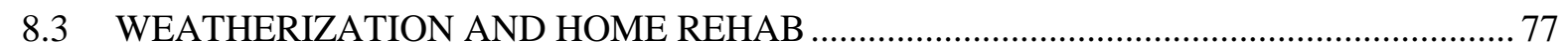

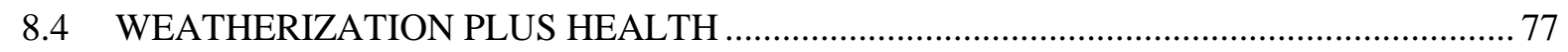

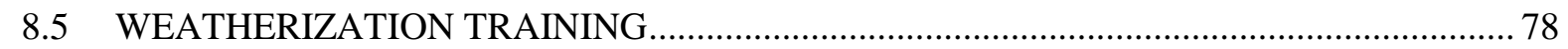

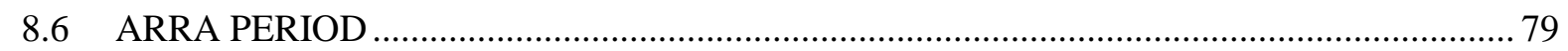

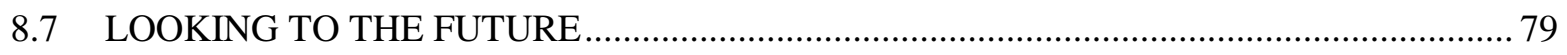

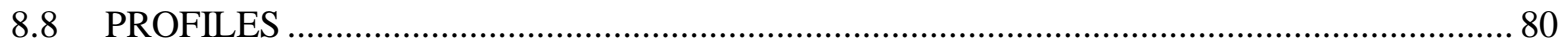

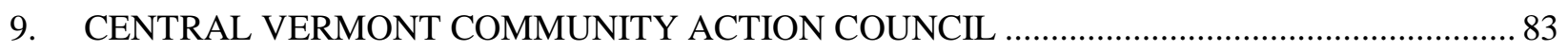

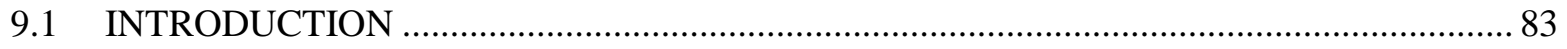

9.2 OVERVIEW OF CVCAC'S PROGRAMS AND SERVICES …...................................... 83

9.3 CVCAC AND THE WEATHERIZATION ASSISTANCE PROGRAM .............................. 85

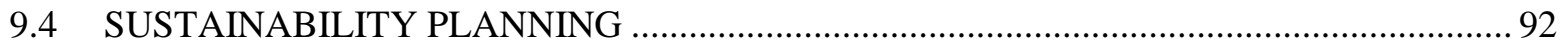

10. CORPORATION FOR OHIO APPALACHIAN DEVELOPMENT - ATHENS............................. 95

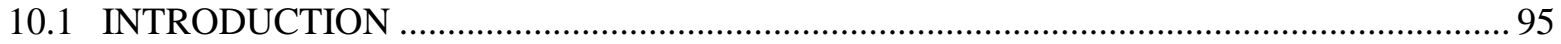

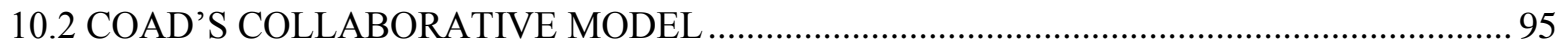

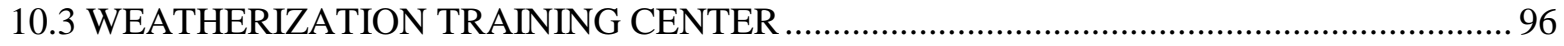

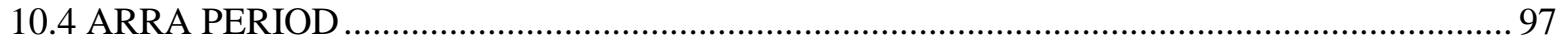

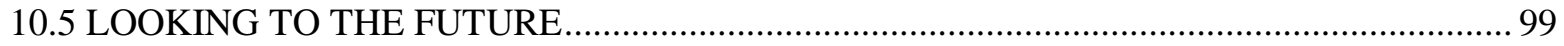

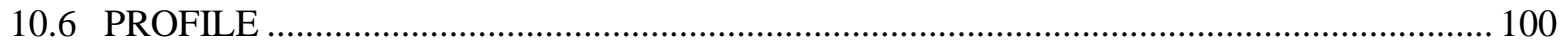

11. ST. JOHNS HOUSING PARTNERSHIP - ST. AUGUSTINE, FLORIDA …............................. 103

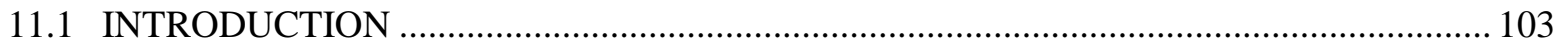

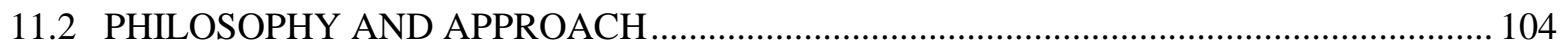

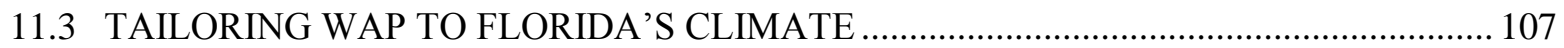

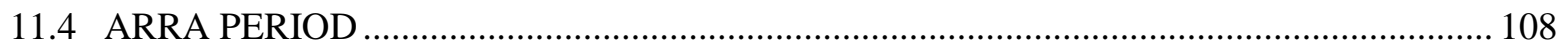

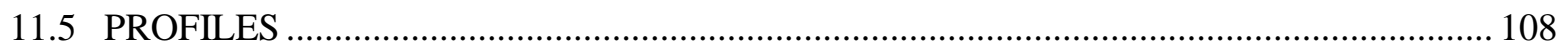

12. SOCIAL DEVELOPMENT COMMISSION - MILWAUKEE, WISCONSIN …....................... 115

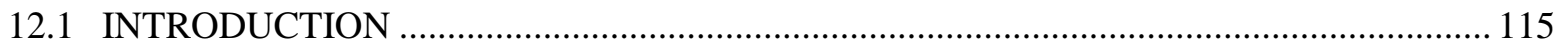

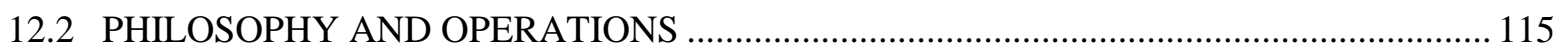

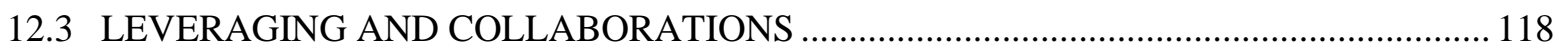

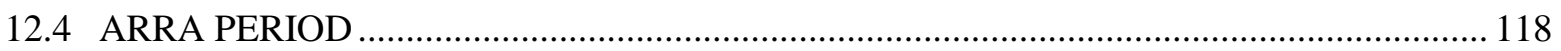

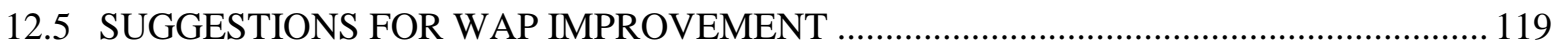

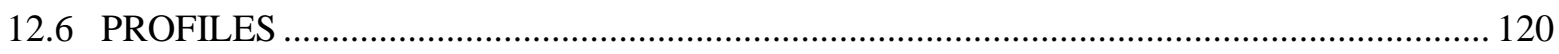

13. ASSOCIATION FOR ENERGY AFFORDABILITY - BRONX, NEW YORK ........................... 123

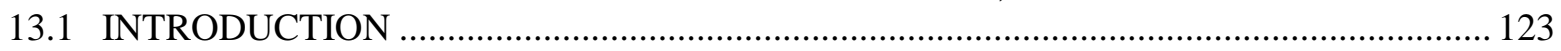

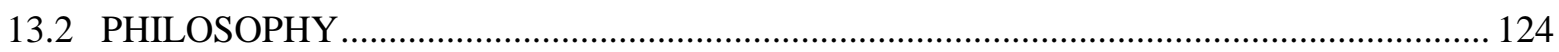

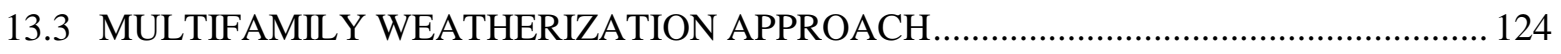

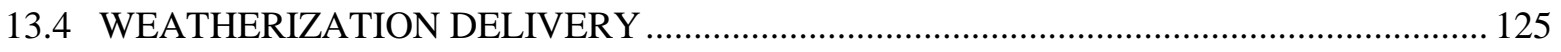

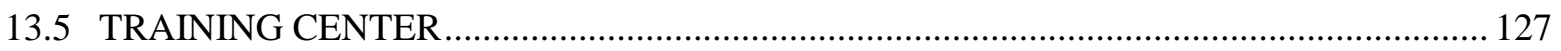

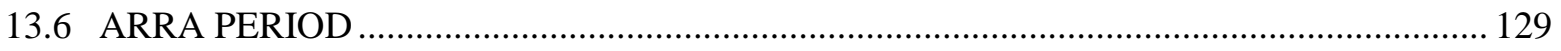

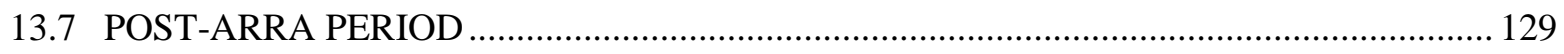

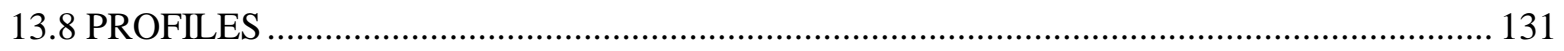

14. NORTHERN MANHATTAN IMPROVEMENT CORPORATION, NEW YORK ........................ 133

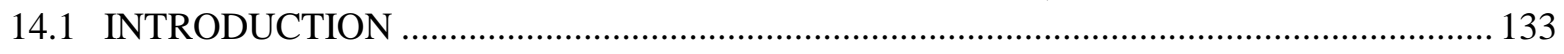

14.2 OVERVIEW OF NORTHERN MANHATTAN IMPROVEMENT CORPORATION ........ 134

14.3 WEATHERIZATION AND THE MULTIFAMILY HOUSING SECTOR ......................... 136

14.4 BARRIERS TO WEATHERIZING THE MULTIFAMILY HOUSING SECTOR IN

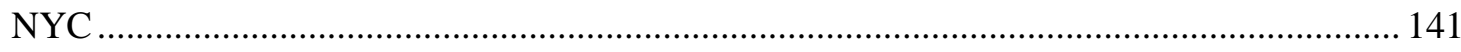

14.5 THE AMERICAN RECOVERY AND REINVESTMENT ACT (ARRA) AND WAP........ 141

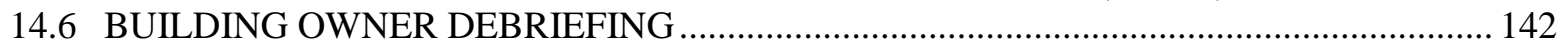

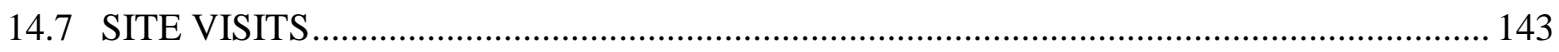

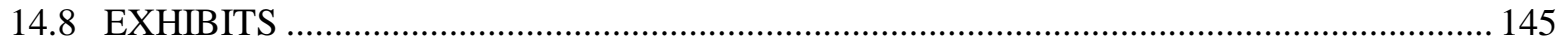




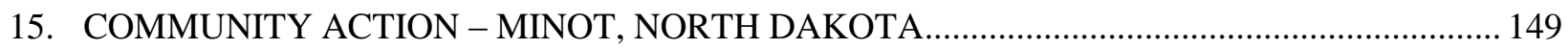

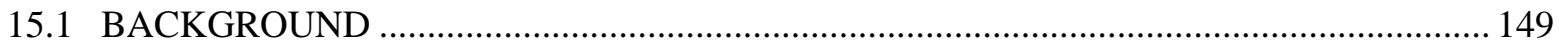

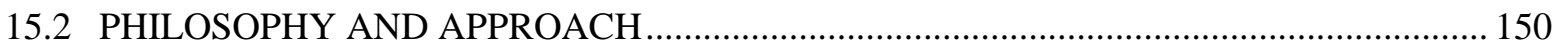

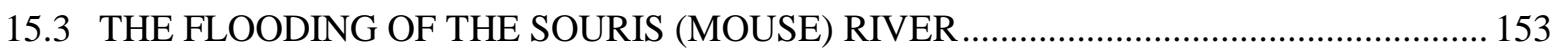

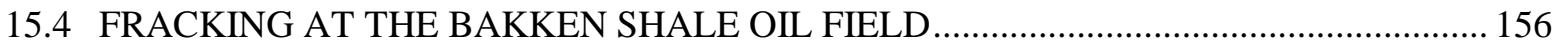

15.5 SUGGESTIONS FOR WAP IMPROVEMENT FROM CREW AND CREW

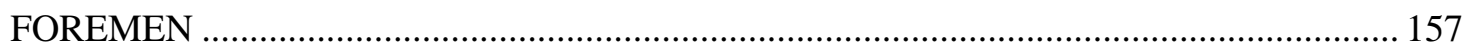

15.6 INTERVIEW WITH CAP-MINOT REGION EXECUTIVE DIRECTOR WILLY

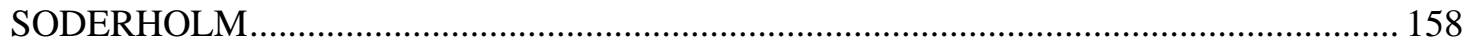

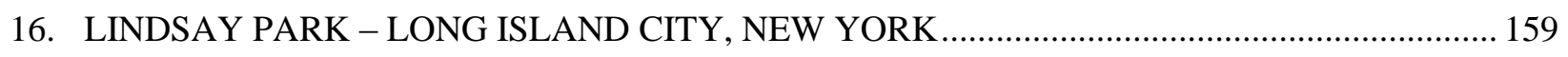

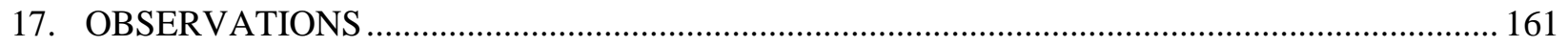

17.1 LOCAL WEATHERIZATION OPERATIONAL PHILOSOPHIES ................................... 161

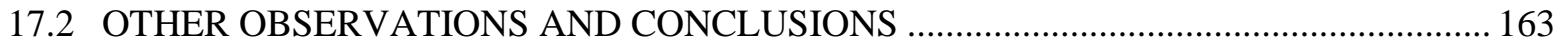

APPENDIX A. PARTNERSHIP AGREEMENT SIGNED BY ALL CAHRA

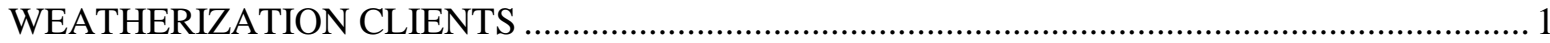





\section{LIST OF FIGURES}

Figure $\quad$ Page

Fig. 2.1. Puerto Rico's Weatherization Assistance Program Organizational Structure (under AFI)........... 8

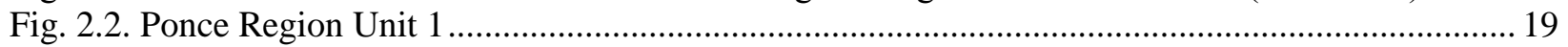

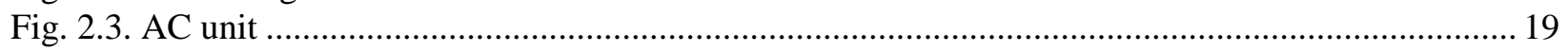

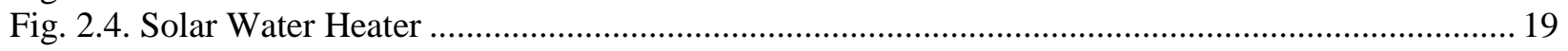

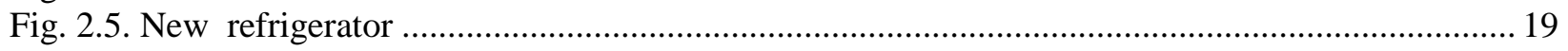

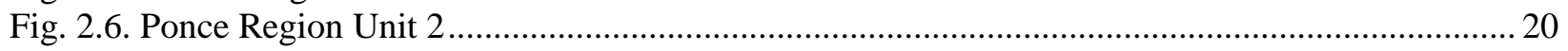

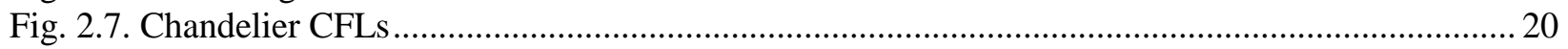

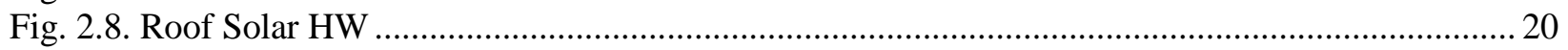

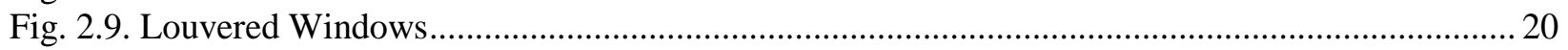

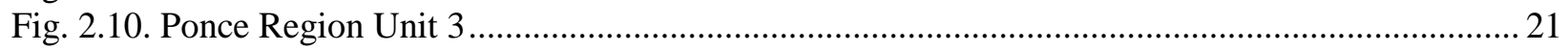

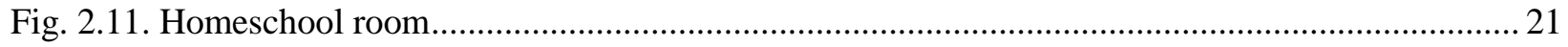

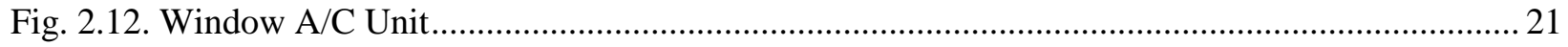

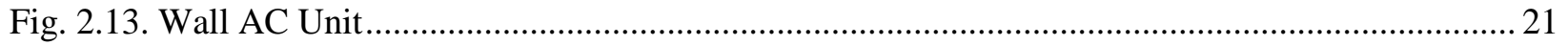

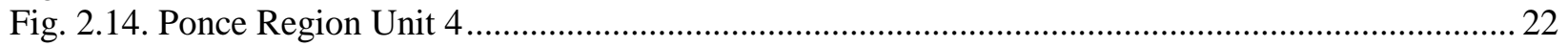

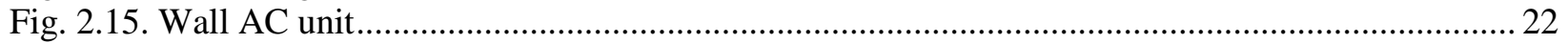

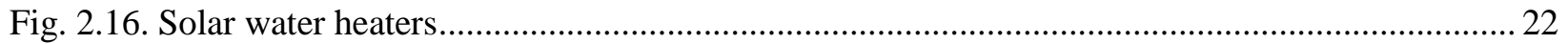

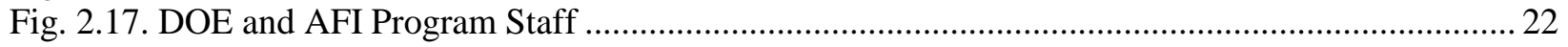

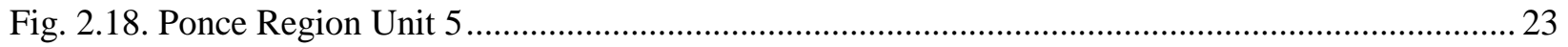

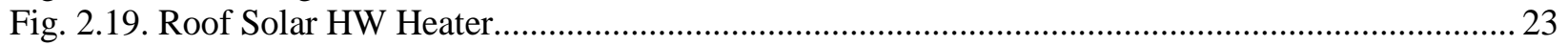

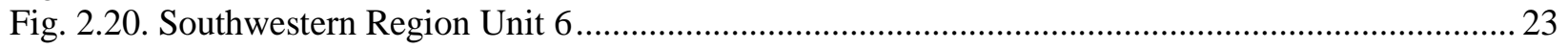

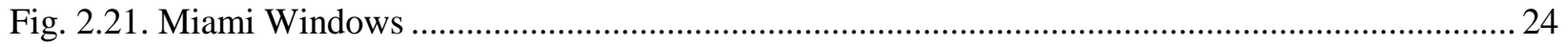

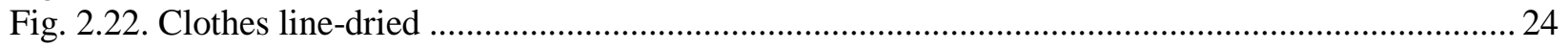

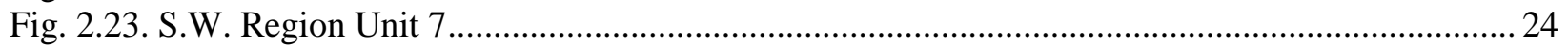

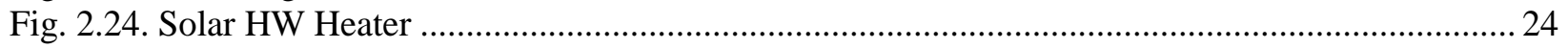

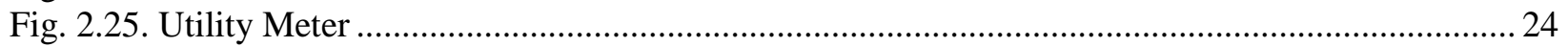

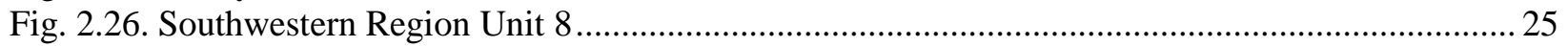

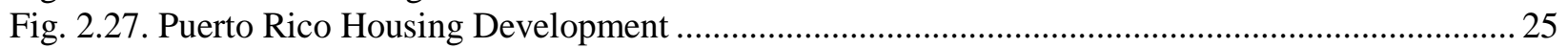

Fig. 2.28. Southwestern Region Unit 9 mango tree ...................................................................... 25

Fig. 2.29. Southwestern housing development with several rooftop solar HW heaters............................. 25

Fig. 3.1. Hot, Dry Climate - Landscape near Grand Junction, CO ...................................................... 27

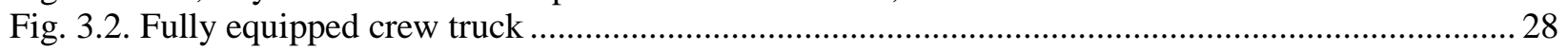

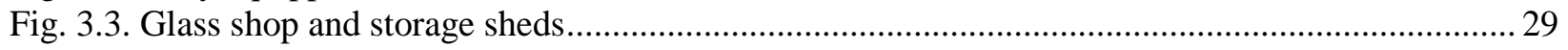

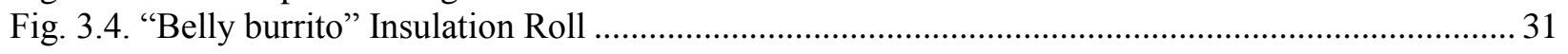

Fig. 3.5 Burrito insulation viewed from side of mobile home. ........................................................ 31

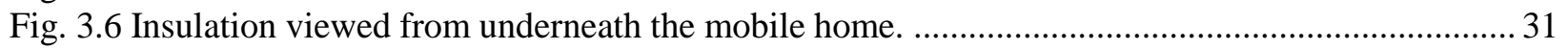

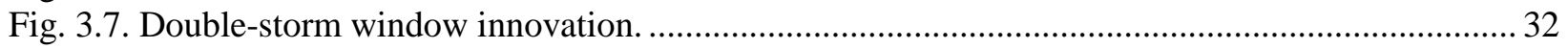

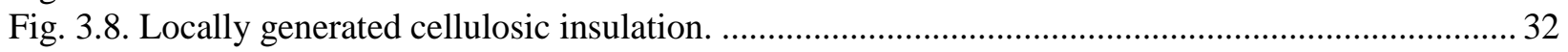

Fig. 3.9. (Pre-weatherization) Grate for sole heat source in residence. Open flames were visible

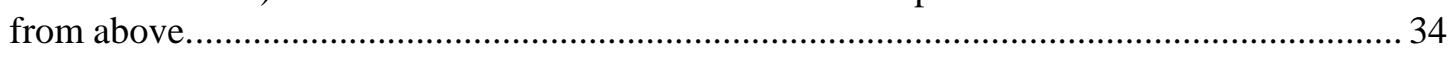

Fig. 3.10. New energy-efficient furnace installed in crawl space with new duct work. .......................... 34

Fig. 3.11. Frank Moreno, Inspector/ Project Coordinator ................................................................. 35

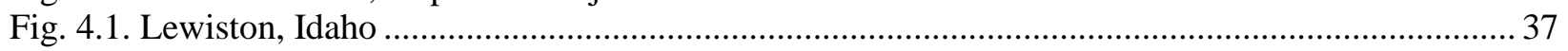

Fig. 4.2. Lewiston Community Action Partnership Mission Statement................................................. 38

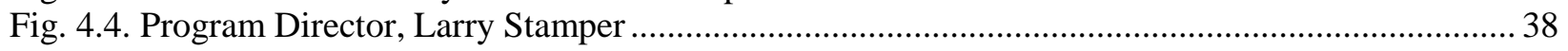

Fig. 4.3. Lewiston CAP Crew Chiefs and Program Director ................................................................ 38

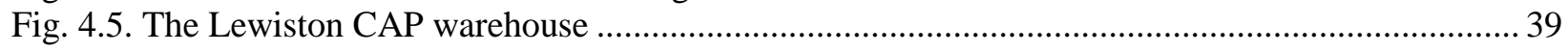




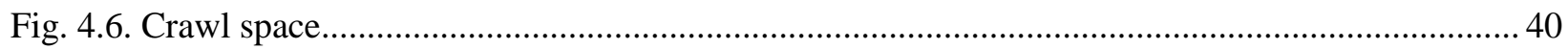

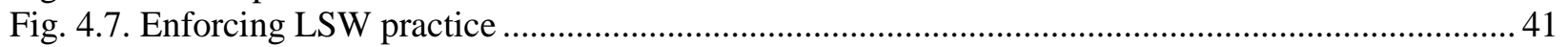

Fig. 4.8. Window replacement crew in full lead protection kit...................................................... 41

Fig. 4.9. Lead-Safe window replacement with plastic garden barrier.................................................. 41

Fig. 4.10. Community Education Specialist, Maria Lacey with energy meter ........................................ 42

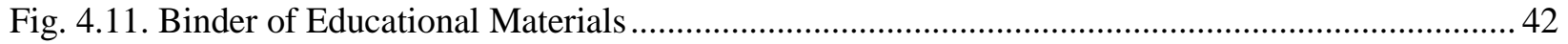

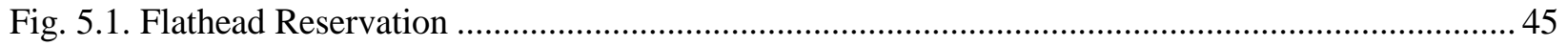

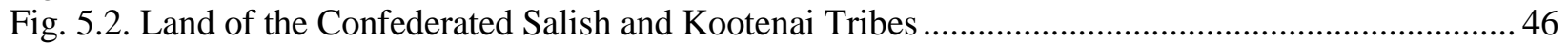

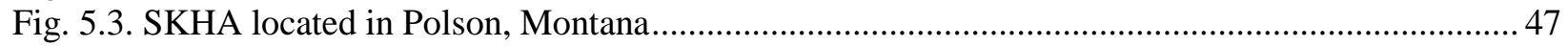

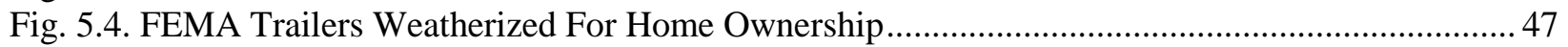

Fig. 5.5. Weatherized mobile home in SKHA's 80-lot trailer park ........................................................ 47

Fig. 5.6. Doreena "Dee" Plant (1966-2011) describing SKHA's weatherization process.......................... 53

Fig. 5.7. Flashing around the perimeter of a mobile home …............................................................... 54

Fig. 5.8. Flashing above a window and around the perimeter of a mobile home .................................. 54

Fig. 6.1. Multifamily building complex weatherized by HELP ............................................................5 57

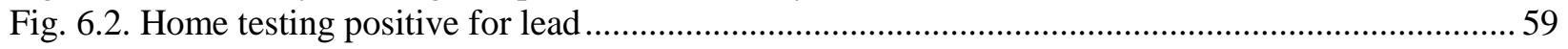

Fig. 6.3. Multifamily unit with solar screens installed (top); close-up of solar screens (bottom)............... 60

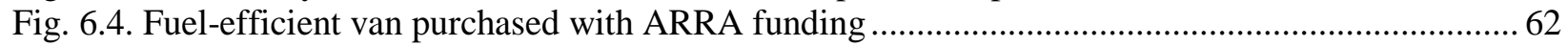

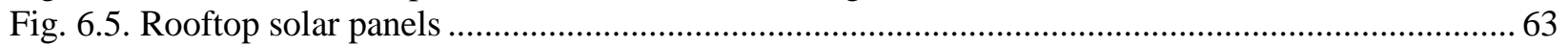

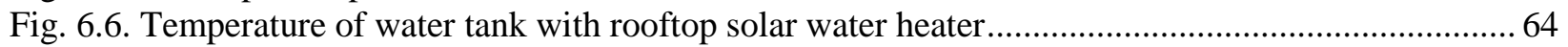

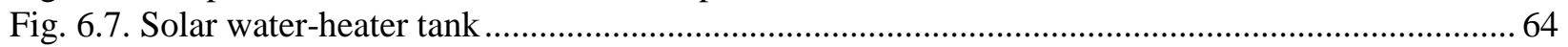

Fig. 7.1. Multifamily unit weatherized by CAHRA; only shade tree in the complex............................... 65

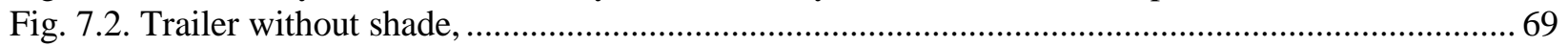

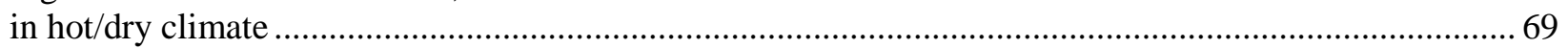

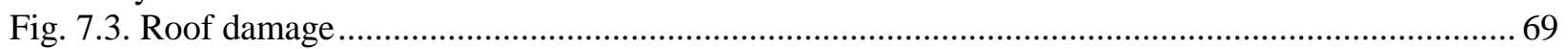

Fig. 7.4. Expansion of doorway for accessibility (after repair) .......................................................... 70

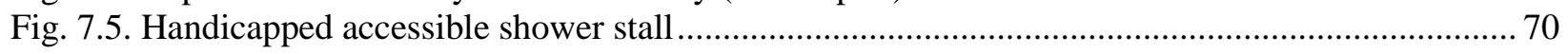

Fig. 7.6. Women's and Children's Shelter, room for donated supplies ................................................ 71

Fig. 7.7. Solar panel for Hot water heater on roof of Women's and children's Shelter ........................... 71

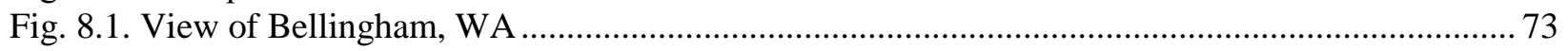

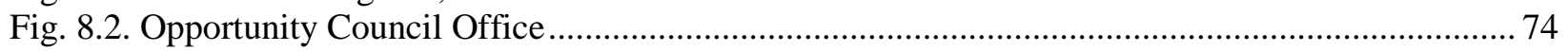

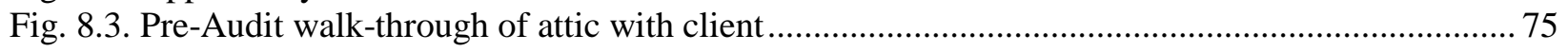

Fig. 8.4. Energy Assistant completing the pre-audit check-list ........................................................ 75

Fig. 8.5. Building Performance Center, the OC's weatherization training facility .................................. 78

Fig. 8.6. Building Performance Center, the OC's weatherization training facility .................................. 78

Fig. 8.7. Education Specialist discussing energy efficiency options ................................................... 80

Fig. 8.8. Kitchen table wrap-up with three recommended energy saving actions ................................... 81

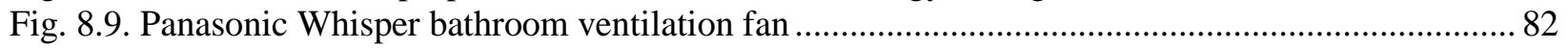

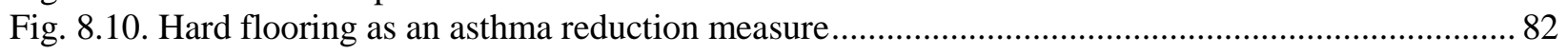

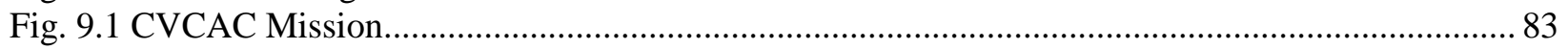

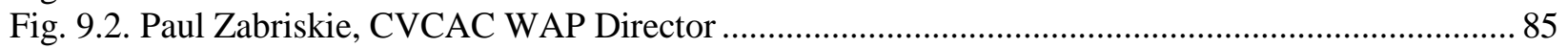

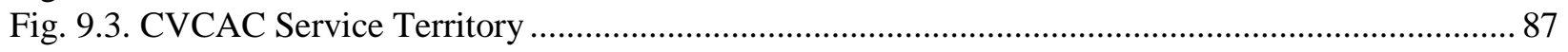

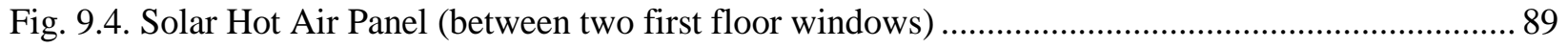

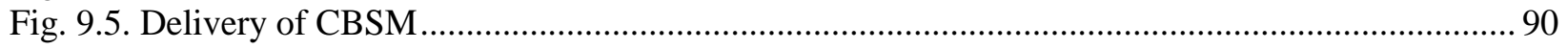

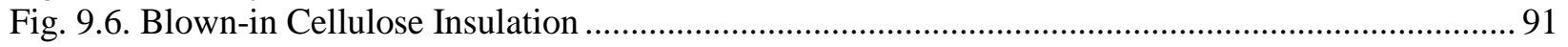

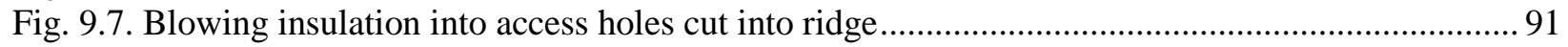

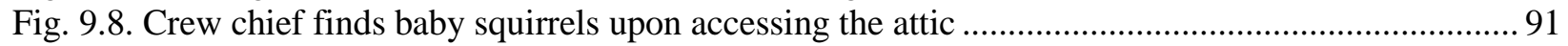

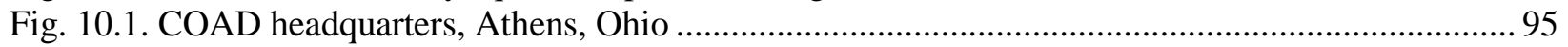

Fig. 10.2. Trainees at Ohio Weatherization Training Center ............................................................ 96

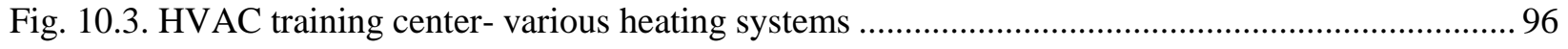

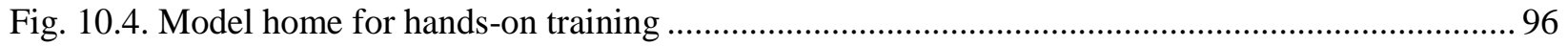




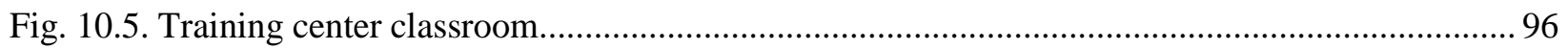

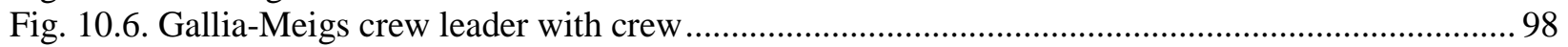

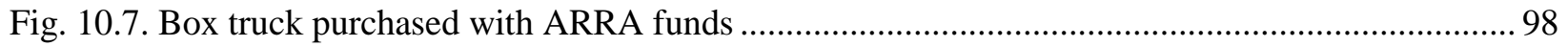

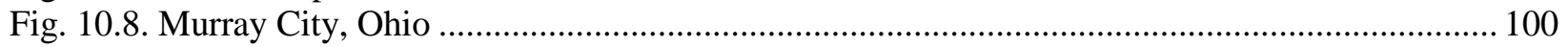

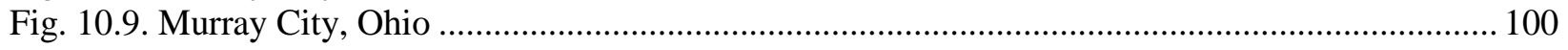

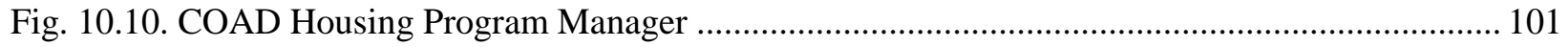

Fig. 10.11. Single-family residence in Murray City; renovated from 1800's theatre.............................. 101

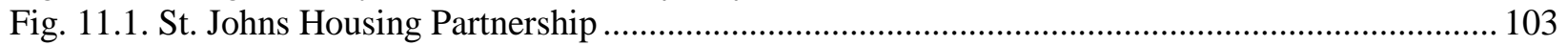

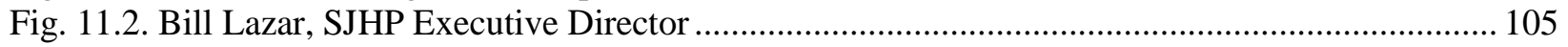

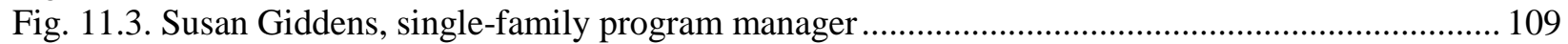

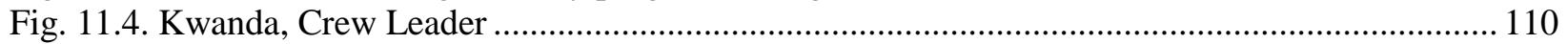

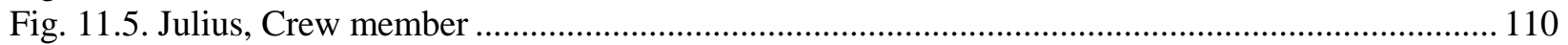

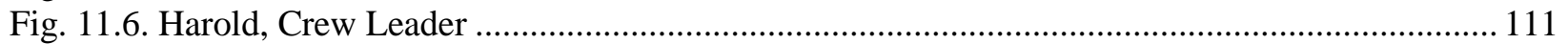

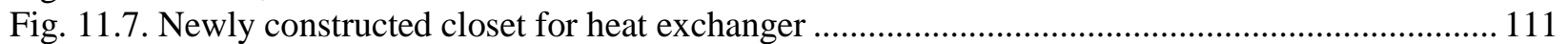

Fig. 11.8. Miss Johnson's home after finishing touches completed by family members. ...................... 112

Fig. 11.9. Miss Johnson's home after complete rehab and weatherization........................................... 112

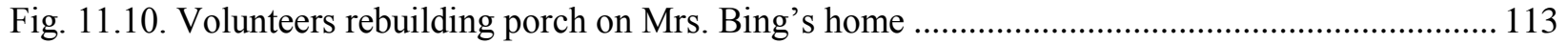

Fig. 11.11. Multifamily apartment house with inverted mini-split unit outside. .................................. 113

Fig. 12.1. Insulation in the attic protects the living space from cold................................................ 121

Fig. 12.2. The lady of the house laughs while displaying newspaper ad featuring the repair and

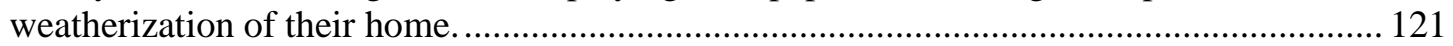

Fig. 13.1. Association for Energy Affordability, Bronx office ........................................................... 123

Fig. 13.2. AEA staff reviewing eligibility documentation with potential program client. ...................... 125

Fig. 13.3. AEA management and staff in a boiler room during site visit ........................................... 127

Fig. 13.4. Training station at AEA's training facility ......................................................................... 128

Fig. 13.5. At AEA's training facility, kitchen mock-up for $\mathrm{CO}$ testing on gas range and fridge

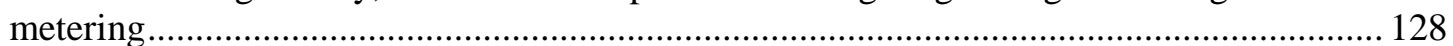

Fig. 13.6. At AEA's training facility, a training station for hands-on work ....................................... 128

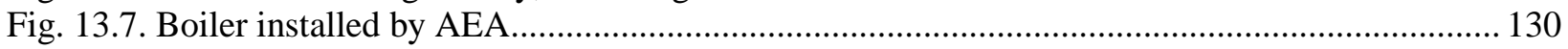

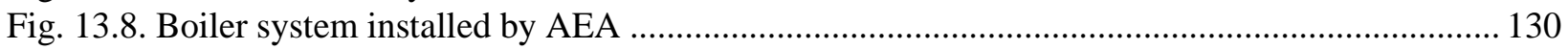

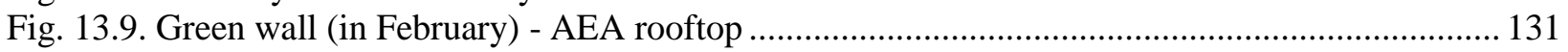

Fig. 13.10. Animated demonstration for distance and in-class instruction ............................................ 132

Fig. 13.11. Senior Citizen home weatherized by AEA. (Note: Upper-floor windows are closed, which is indicative of uncomfortable heat distribution. Uneven heat distribution is a

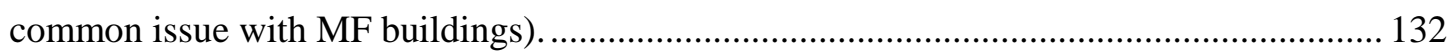

Fig. 14.1. Dan Rieber, NMIC Weatherization Director ....................................................................... 133

Fig. 14.2. View of sky from courtyard of multifamily residence recently weatherized by NMIC ........... 133

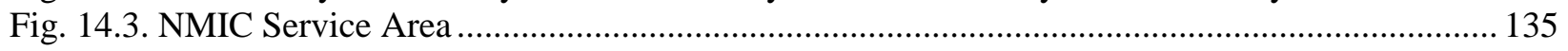

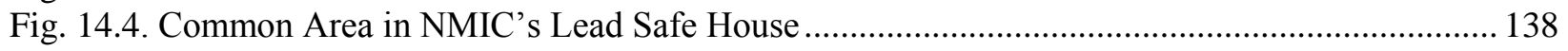

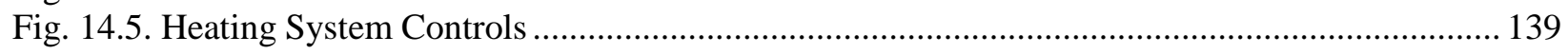

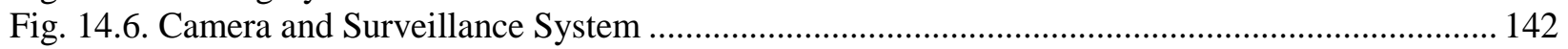

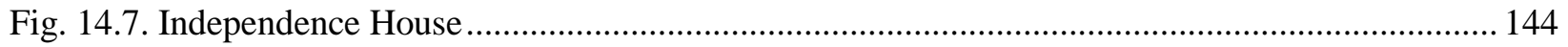

Fig. 14.8. C. Virginia Fields Manhattan Lead Safe House ….............................................................. 144

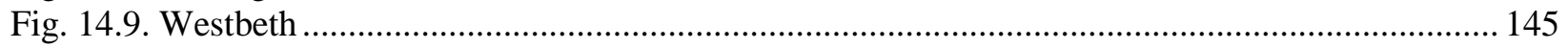

Fig. 15.1. CAP-Minot Region Weatherization Staff......................................................................... 149

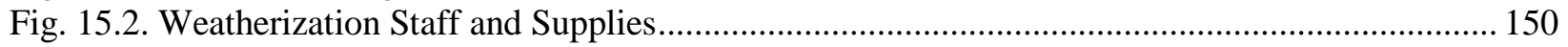

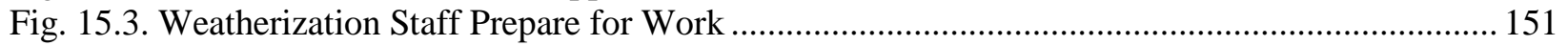

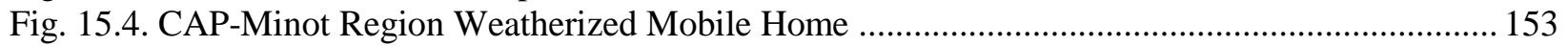

Fig. 15.5. The Flooding of the Souris River in Minot

Fig. 15.6. Weatherization Staff Preparing for the Flood.................................................................. 154 
Fig. 15.7. Operating the Program from off site

Fig. 15.8. CAP-Minot Region Office Post Flood.

Fig. 15.9. Weatherization Warehouse Flooded.

Fig. 15.10. Weatherization Staff Clean Up.....

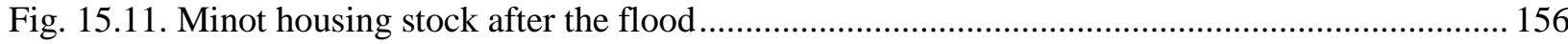

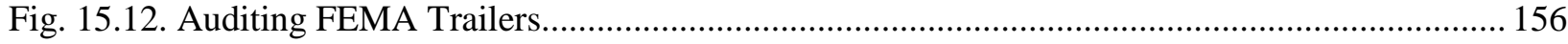

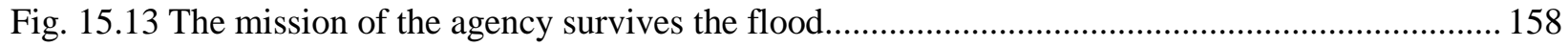

Fig. 16.1. Rendering of Lindsay Park Housing Corporation .............................................................. 159

Fig. 16.2. Board of Directors with Cora Dix-Austin in the center and Thelma Arceo of the

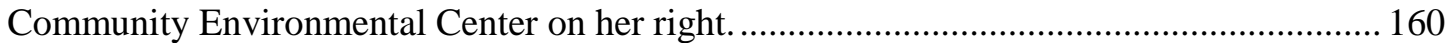

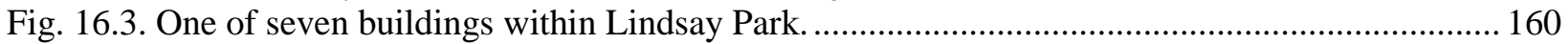




\section{LIST OF TABLES}

Table

Table 1. Decision Matrix for Selection of Case Studies ..................................................................... 3

Table 9.2. CVCAC Home Energy Programs and Funding Sources ....................................................... 93 



\section{ACRONYMS AND ABBREVIATIONS}

\begin{tabular}{|c|c|}
\hline ABWS & Apartment Building Work Scope \\
\hline ACMH & Assistance for Case Management and Housing \\
\hline AEA & Association for Energy Affordability \\
\hline AEE & Energy Affairs Administration \\
\hline AEP & American Electric Power \\
\hline AFI & Infrastructure Financing Authority \\
\hline APS & Arizona Public Service \\
\hline ARRA & American Recovery and Reinvestment Act \\
\hline ASHRAE & American Society of Heating, Refrigeration, and Air-Conditioning Engineers \\
\hline BIA & Bureau of Indian Affairs \\
\hline BPC & Building Performance Center \\
\hline BPI & Building Performance Institute \\
\hline BWR & Building Weatherization Report \\
\hline CAA & Community Action Agency \\
\hline CACs & Community Action Councils \\
\hline CAHRA & Community Action Human Resources Agency \\
\hline CAP & Community Action Program \\
\hline CAP & Community Action Partnership \\
\hline CAZ & Combustion Appliance Zone \\
\hline CDBG & Community Development Block Grant \\
\hline CEC & Community Environmental Center \\
\hline CFLs & Compact Fluorescent Lamps \\
\hline $\mathrm{CO}$ & Carbon Monoxide \\
\hline COAD & Corporation for Ohio Appalachian Development \\
\hline CBSM & Community Based Social Marketing \\
\hline CSG & Conservation Services Group \\
\hline CSKT & Confederated Salish and Kootenai Tribes \\
\hline CVCAC & Central Vermont Community Action Council \\
\hline CVI & Core Values Index \\
\hline DEO & Department of Economic Opportunity \\
\hline DOE & Department of Energy \\
\hline EISA & Energy and Independence Security Act \\
\hline ECMS & Energy Conservation Measures \\
\hline ED & Executive Director \\
\hline FEMA & Federal Emergency Management Association \\
\hline GPL & General Priority List \\
\hline HAP & Hocking-Athens-Perry \\
\hline HELP & Housing, Emergency Services, Life Skills, and Prevention \\
\hline HEPA & High-efficiency Particulate Air \\
\hline HERS & Home Energy Rating Score \\
\hline HIP & Housing Improvement Program \\
\hline HPwES & Home Performance with Energy Star Program \\
\hline HR & Housing Resources \\
\hline HSS & Health and Human Services \\
\hline HUD & Housing and Urban Development \\
\hline HVAC & Heating, Ventilation and Air Conditioning \\
\hline ICDBG & Indian Community Development Block Grant \\
\hline
\end{tabular}




$\begin{array}{ll}\text { LIHEAP } & \text { Low-income Home Energy Assistance Program } \\ \text { LIHTC } & \text { Low-income Housing Tax Credit } \\ \text { LMF } & \text { Large Multifamily } \\ \text { LRRP } & \text { Lead Renovation, Repair and Painting } \\ \text { LSW } & \text { Lead-safe Weatherization } \\ \text { MF } & \text { Multifamily } \\ \text { MOU } & \text { Memorandum of Understanding } \\ \text { MPP } & \text { Multifamily Performance Program } \\ \text { NCR } & \text { National Church Residences } \\ \text { NEAT } & \text { National Energy Audit Tool } \\ \text { NETL } & \text { National Energy Technology Laboratory } \\ \text { NIP } & \text { Neighborhood Improvement Project } \\ \text { NMIC } & \text { Northern Manhattan Improvement Corporation } \\ \text { NSP } & \text { National Stabilization Program } \\ \text { NYSERDA } & \text { New York State Energy Research and Development Authority } \\ \text { OC } & \text { Opportunity Council } \\ \text { OJT } & \text { On-the-Job Training } \\ \text { O\&M } & \text { Operations and Management } \\ \text { ORNL } & \text { Oak Ridge National Laboratory } \\ \text { OWTC } & \text { Ohio Weatherization Training Center } \\ \text { PAGE } & \text { Performance and Accountability for Grants in Energy } \\ \text { PIPP } & \text { Percentage of Income Payment Plan } \\ \text { PLAT } & \text { Priority List Assessment and Testing Form } \\ \text { PREAT } & \text { Puerto Rico Energy Audit Tool } \\ \text { PREPA } & \text { Puerto Rico Electric Power Authority } \\ \text { PY } & \text { Program Year } \\ \text { QA } & \text { Quality Assurance } \\ \text { REM } & \text { Residential Energy Modeling } \\ \text { RESNET } & \text { Residential Energy Services Network } \\ \text { RFP } & \text { Request for Proposal } \\ \text { RGGI } & \text { Regional Greenhouse Gas Initiative } \\ \text { SDC } & \text { Social Development Commission } \\ \text { SERC } & \text { Sustainable Energy Resources for Consumers } \\ \text { SES } & \text { Socio-economic Status } \\ \text { SHIP } & \text { State Housing Initiative Partnership } \\ \text { SIR } & \text { Savings-to-Investment Ratio } \\ \text { SJHP } & \text { St. Johns Housing Partnership } \\ \text { SKHA } & \text { Salish and Kootenai Housing Authority } \\ \text { SMS } & \text { Simonson Management Services } \\ \text { SWH } & \text { Solar Water Heating } \\ \text { T\&TA } & \text { Training and Technical Assistance } \\ \text { ULEEP } & \text { Utility Low-income Electric Efficiency Program } \\ \text { URRD } & \text { Utility Repair Replacement Deposit } \\ \text { VOC } & \text { Volatile Organic Compounds } \\ \text { WAP } & \text { Weatherization Assistance Program } \\ \text { W2 } & \text { Wisconsin Works } \\ & \end{array}$




\section{ACKNOWLEDGEMENTS}

The work presented in this report was funded by the U.S. Department of Energy's (DOE) Office of Weatherization and Intergovernmental Program (OWIP).

Many individuals contributed to this endeavor. We wish to thank everyone from the local agencies who spent time with the case study team and who were kind enough to review drafts of their cases for accuracy and fairness. We wish to thank Cynthia Simonson and the staff of SMS for their suggestions on high-performing and innovative agencies and their review of a draft version of this report. We also thank Tim Lenahan and Russ Shaber for their comments on the draft version. We greatly appreciate the editorial services provided by Em Turner Chitty. 



\section{EXECUTIVE SUMMARY}

The U.S. Department of Energy (DOE) administers the Weatherization Assistance Program (hereinafter referred to as WAP or the Program) in order to provide grants to states, territories, tribes, and the government of Washington, DC; these Grantees then fund local agencies (known as Subgrantees) to weatherize the homes of low-income American householders. Home weatherization includes such measures as adding wall or attic insulation, sealing air leaks, baseload measures (i.e. replacing refrigerators with more energy-efficient ones) or replacing furnaces. With weatherization measures installed, homeowners can significantly reduce their energy costs.

This report is one of approximately two dozen reports coming out of two evaluations of WAP being conducted by Oak Ridge National Laboratory (ORNL) at the direction of DOE. The first evaluation, known as the Retrospective Evaluation, focuses on the 2008 WAP Program Year (PY). The second evaluation, called the American Recovery and Reinvestment Act of 2009 (ARRA) Period Evaluation, focuses on WAP PY 2010. Both PY 2008 and PY 2010 were chosen as the subjects of the evaluations because they represent two distinct phases in the history of the Program: During PY 2008, the Program supported the weatherization of approximately 100,000 households using Federal appropriations of approximately $\$ 250$ million. This can be regarded as a baseline level of expenditure. PY 2010, however, fell in the middle of the ARRA period, when the program experienced a dramatic jump of $\$ 5$ billion in funding, with the expectation that between 600,000 and 1,000,000 homes would be weatherized in a three- to four-year period. The two efforts evaluate what are essentially two very different programs; the comparison will yield very useful information for program-management purposes.

The weatherization process itself is straightforward: income-eligible households enter the program, energy audits are performed on the homes, energy efficiency measures that meet a savings-to-investment ratio test, along with appropriate health and safety measures, are installed in the homes, and final inspections are conducted. Sometimes agencies need to defer weatherization if homes are in extremely poor physical condition or present health and safety risks to their personnel. Within this general program space a very active, diverse, and innovative national weatherization network has evolved. This document reports on 14 successful, but very diverse local weatherization programs from around the United States and its territories. ${ }^{1}$ Its purpose is to show, both in narrative and illustrations, how weatherization efforts under the program actually work on the ground in different contexts. The programs were chosen to represent a wide range of local weatherization programs that are notable for the following characteristics:

- Climate. Because "weatherization" means different things in different climates, agencies in very different climate areas of the country were chosen to illustrate the different weatherization solutions necessary in such a very large and diverse country as the United States.

- Outstanding Management and Leadership Style. As with most business and non-profit entities, management and leadership styles are keys to establishing how entities function. The innovative management styles of agencies in Idaho, Washington, Vermont, Ohio, Florida, and New York State can help show the way to possible future models for the management of weatherization agencies.

- High Energy Savings. Some agencies achieved unusually high energy savings. Agencies in Vermont, Colorado, Ohio, Florida, and North Dakota are profiled to show how this key goal can be achieved.

\footnotetext{
${ }^{1}$ A fifteenth case describes the extraordinary story of Lindsay Park.
} 
- Innovation and Efficiency. Some agencies were remarkable for their innovativeness and efficiency. Agencies in Colorado, Idaho, Arizona, Washington, and Vermont were chosen as models for these qualities.

- Specialists in Multifamily (MF) Housing. Because multifamily weatherization carries many important benefits, not the least of which is cost-effectiveness, agencies in Nevada and New York that do outstanding work on MF units were included.

- Specialists in Urban Weatherization. Operating in an urban environment poses challenges with rundown housing stock and cultural barriers to weatherization. Several agencies in Nevada, Wisconsin, and New York that specialize in urban weatherization were chosen.

- Specialists in Rural Weatherization. Rural operations pose different, but equally great challenges to weatherization. Agencies in Montana, Arizona, Washington, Ohio and Vermont were chosen to illustrate solutions in rural settings.

- Success at Leveraging External Funding. DOE provides funds needed for weatherization, but some agencies have proven to be extraordinarily resourceful in using DOE funds to leverage external dollars - whether from private or public sources - to help weatherize even more homes and bear the often considerable costs of home repairs and other needs.

- One-Stop Shops. Some agencies developed a "one-stop shop" approach. In other words, agencies that offer multiple social services, including weatherization, are pursuing innovations to cross-link their programs to make accessing these programs by their clients more user-friendly.

- Non-State Programs. ARRA funding was extended to Native American Tribes and to Puerto Rico, a United States territory. Profiles of the Salish-Kootenai and of Puerto Rico show how these programs work.

- In-House Crew Model. Some agencies use in-house crews to install weatherization materials rather than using external contractors. Agencies in Colorado, Washington, Florida, and North Dakota show how this works.

- External Contractor Model. In contrast, some agencies lean heavily on private contract crews. Agencies in Puerto Rico and Wisconsin illustrate this model.

- Agencies Operating Weatherization Training Centers. Some weatherization agencies operate fully fledged Training Centers that attract trainees from all over their state or region; agencies in Washington, Ohio, and New York show how they contribute to economic development and skills enrichment in this way. 


\section{OBSERVATIONS}

\section{Effective Management of Local Weatherization Programs}

The case studies presented below describe the philosophies, operational models, and other important characteristics of a very diverse set of local weatherization agencies. It is shown that there is no one best model (e.g., all in-house crews versus all contracting). It is also shown that models need to fit the context: for example, a very small program may not be able to support an in-house crew year round. Diversity is also found with respect to auditing tools used (computer versus priority lists), housing stock addressed (single-family and mobile homes versus large multi-family), and typical measures installed (wall and ceiling insulation in Colorado versus rooftop solar hot water in Puerto Rico).

There are also many commonalities amongst the programs in how they are envisioned and implemented. These commonalities provide the foundation upon which successful programs flourish regardless of their distinct characteristics. The observations presented here are organized around the Principles and Practices discussed by Peter Drucker in his seminal book, Managing the Nonprofit Organization ${ }^{2}$. Drucker outlines several general categories in which successful nonprofit organizations excel. Our observations fall into these general categories: mission; commitment; respect; quality; innovation; and resilience:

- Mission - All of the agencies visited have a strong sense of mission. There is no confusion about what the agencies need to accomplish. This focus, the shared common understanding, infuses all other aspects of their organizations.

- Commitment - In agency after agency, we observed weatherization staff deeply committed to their jobs and agencies deeply committed to their staff. One observation made across agencies supports both of these points: a substantial majority of the core weatherization staff has decades of tenure at their agencies. The agencies are deeply committed to their communities as well.

- $\quad$ Respect - Organizational culture and pride in the weatherization work are evident in the respect that the weatherization staff gives to their clients. The agencies also respect their staff. This is exemplified by the empowerment of staff in decision-making and other responsibilities.

- Quality - The focus on mission, commitment to weatherization, and respect given their employers combine to create conditions for high quality of work. We witnessed a great deal of pride in the quality of their work amongst the long-time weatherization auditors, crew chiefs and crew. Quality is also supported by a plethora of training opportunities.

- Innovation - The agencies need to be both innovative and creative, technically and organizationally. Almost daily, auditors and crews encounter novel and extraordinary home construction situations. Organizational innovation and creativity can be expressed in numerous fashions. For example, creative approaches are often required to "braid" (combine) leveraged funds to maximize services delivered to clients.

- Resilience - The agencies we visited are quite resilient. They somehow survive year-after-year to pursue their missions despite tight and uncertain budgets, uncertainty regarding when monies will be available for expenditure, and fairly restrictive regulatory requirements. Their resilience and fortitude were tested during the ARRA period.

\footnotetext{
${ }^{2}$ Drucker, Peter F. (1990). Managing the Nonprofit Organization: Principles and Practices. HarperCollins: New York, NY.
} 


\section{OTHER OBSERVATIONS}

Many local conditions prevent a one-size-fits-all approach for the implementation of weatherization programs. For example, programs that weatherize relatively few units per year cannot afford full-time, year round in-house crews. Some local economic situations are more conducive to using contractors than others. The typical suite of measures installed may also lead a program to choose an in-house model, a contracting model or a hybrid model.

Another observation is that the national weatherization network does not get the credit it deserves for dealing with the diversity of conditions it faces in the field. It was mentioned above that the local programs can adjust to different climates, housing stock, fuel types, and demographics. The network also can adapt to their particular leveraging opportunities, be they related to healthy homes or weatherizing entire communities.

Energy education was seen to be quite effective as it relates to its impact on energy consumption at a household level. The best models witnessed included having a separate energy educator who either accompanied the auditor or visited the home pre-audit. Client agreements also seem to work well. Auditors and crew members can provide energy education if given the time, although this time was in short supply during the ARRA period. The intense focus on production limited the amount of time any agency staff could spend with households.

After witnessing how programs ramped up and then down again during the ARRA period and listening to their travails during this period of time, one can conclude that more appreciation is due the national weatherization network for how it dealt with the ARRA funding and Davis-Bacon regulations, which mandated the levels at which local contractors and local agency staff had to be recompensed.

Even with the added ARRA funding, the number of homes eligible for weatherization is far greater than available resources can serve. Many agencies have long waiting lists; many others do not advertise their programs in an attempt to keep waiting lists manageable. When asked, most estimated that it would take many decades to serve the number of eligible homes given current funding.

It was observed that increased funding during the ARRA period allowed DOE to pass more money down to the states and agencies for training and technical assistance (T\&TA). This additional money afforded by a larger program actually led to better training and better quality assurance in the field.

The larger program allowed DOE to experiment with the installation of renewable energy and energy efficient measures not currently allowed by standard program rules. The several agencies visited that received Sustainable Energy Resources for Consumers (SERC) grants had no problems incorporating these new measures into their programs; most clients reported they were thrilled to be recipients of these measures.

A larger and more integrated program could help more households in number and households not currently served by the program. Falling into the latter category are households that agencies walk-away from (i.e., decline to weatherize) because they are in such bad shape or due to the presence of lead or asbestos. It is an ironic observation that many of the truly worse-off households cannot be served by WAP for these reasons. A program integrated with home repair and renovation resources from other federal agencies could accommodate more of these households. 



\section{INTRODUCTION}

The U.S. Department of Energy (DOE) administers the Weatherization Assistance Program (hereinafter referred to as WAP or the Program) in order to provide grants to states, territories, tribes, and the government of Washington, DC; these Grantees then fund local agencies (known as Subgrantees) to weatherize the homes of low-income American householders. Home weatherization includes such measures as adding wall and attic insulation, sealing air leaks, replacing refrigerators, or replacing furnaces. With weatherization measures installed, homeowners can significantly reduce their energy costs. On a national level, WAP works towards the nation's more general goal of energy independence by reducing home energy use. Under the weatherization assistance program, income-eligible households in a wide variety of settings, from Puerto Rico's hot and humid environment to North Dakota's frigid High Plains, have been able to get their homes weatherized at no cost to them.

This report is one of approximately two dozen reports coming out of two evaluations of WAP being conducted by Oak Ridge National Laboratory (ORNL) at the direction of DOE. The first evaluation, known as the Retrospective Evaluation, focuses on the 2008 WAP Program Year (PY). The second evaluation, called the American Recovery and Reinvestment Act of 2009 (ARRA) Period Evaluation, focuses on WAP Program Year 2010. These Program Years were chosen as the subjects of the evaluations because they represent two distinct phases in the history of the Program: During PY 2008, the Program supported the weatherization of approximately 100,000 households using Federal appropriations of approximately $\$ 250$ million. This can be regarded as a baseline level of expenditure. PY 2010, however, fell in the middle of the ARRA period, when the program experienced a dramatic jump of $\$ 5$ billion in funding, with the expectation that between 600,000 and 1,000,000 homes would be weatherized in a three- to four-year period. The two efforts evaluate what are essentially two very different programs; the comparison will yield very useful information for program-design purposes.

To get a clear picture of both phases, a great deal of information had to be gathered. Natural gas and electric billing histories were collected from utility companies to estimate program energy savings. Grantees and Subgrantees were asked to complete exhaustive surveys about how they implemented their weatherization programs and how much their programs cost. In addition, weatherization staff and occupants who received weatherization services were surveyed to learn about their experiences with the Program.

The weatherization process itself is simply described: income-eligible households enter the program, energy audits are performed on the homes, energy efficiency measures that meet a savings-to-ratio test, along with appropriate health and safety measures, are installed in the homes, and final inspections are conducted. Sometimes agencies need to defer weatherization if homes are in extremely poor physical condition or present health and safety risks to their personnel. Within this general program space a very active, diverse, and innovative national weatherization network has evolved. The present document reports on 14 successful, but very diverse local weatherization programs from around the United States and its territories. ${ }^{3}$ Its purpose is to show, both in narrative and illustrations, how weatherization efforts under the program actually work on the ground in different contexts.

The programs were chosen to represent a wide range of local weatherization programs. Table 1 displays, in a detailed grid form, the considerations that went into choosing the agencies for the present report.

\footnotetext{
${ }^{3}$ A fifteenth case describes the extraordinary story of Lindsay Park.
} 
1) Climate. Because "weatherization" means different things in different climates, agencies in very different climate areas of the country were chosen to illustrate the different weatherization solutions necessary in such a very large and diverse country as the United States.

2) Outstanding Management and Leadership Style. As with most business and non-profit entities, management and leadership styles are keys to establishing how entities function. The innovative management styles of agencies in Idaho, Washington, Vermont, Ohio, Florida, and New York State can help show the way to possible future models for the management of weatherization agencies.

3) High Energy Savings. Some agencies achieved unusually high energy savings. Agencies in Vermont, Colorado, Ohio, Florida, and North Dakota are profiled to show how this key goal can be achieved.

4) Innovation and Efficiency. Some agencies were remarkable for their innovativeness and efficiency. Agencies in Colorado, Idaho, Arizona, Washington, and Vermont were chosen to illustrate models for these qualities.

5) Specialists in Multifamily (MF) Housing. Because multifamily weatherization carries many important benefits, not the least of which is cost-effectiveness, agencies in Nevada and New York that do outstanding work on MF units were included.

6) Specialists in Urban Weatherization. Operating in an urban environment poses challenges with rundown housing stock and cultural barriers to weatherization. Several agencies in Nevada, Wisconsin, and New York that specialize in urban weatherization were chosen.

7) Specialists in Rural Weatherization. Rural operations pose different, but equally great challenges to weatherization. Agencies in Montana, Arizona, Washington, Ohio and Vermont were chosen to illustrate solutions in rural settings.

8) Success at Leveraging External Funding. DOE can provide some of the funds needed for weatherization, but some agencies have proven to be extraordinarily resourceful in leveraging external dollars - whether from private or public sources - to help weatherize even more homes and bear the often considerable costs of home repairs and other needs.

9) One-Stop Shops. Some agencies developed a "one-stop shop" approach. In other words, agencies that offer multiple social services, including weatherization, are pursuing innovations to cross-link their programs to make accessing these programs by their clients more user-friendly.

10) Non-State Programs. ARRA funding was extended to Native American Tribes and to Puerto Rico, a United States territory. Profiles of the Salish-Kootenai and of Puerto Rico show how these programs work.

11) In-House Crew Model. Some agencies use in-house crews to do weatherization. Agencies in Colorado, Washington, Florida, and North Dakota show how this works.

12) External Contractor Model. In contrast, some agencies lean heavily on private contract crews. Agencies in Puerto Rico and Wisconsin illustrate this model.

13) Agencies Operating Weatherization Training Centers. Some weatherization agencies operate fully fledged Training Centers that attract trainees from all over their state or region; agencies in Washington, Ohio, and New York show how they contribute to economic development and skills enrichment in this way. 
Table 1. Decision Matrix for Selection of Case Studies

\begin{tabular}{|c|c|c|c|c|c|c|c|c|c|c|c|}
\hline $\begin{array}{l}\text { Selection } \\
\text { Criteria }\end{array}$ & Climate & $\begin{array}{l}\text { Outstanding } \\
\text { Mgmt. Style }\end{array}$ & $\begin{array}{l}\text { High } \\
\text { Energy } \\
\text { Savings }\end{array}$ & $\begin{array}{l}\text { Innovation } \\
\text { and } \\
\text { Efficiency }\end{array}$ & $\begin{array}{l}\text { Multi- } \\
\text { Family }\end{array}$ & $\begin{array}{l}\text { Urban/ } \\
\text { Rural } \\
\text { Model }\end{array}$ & $\begin{array}{l}\text { Leveraging } \\
\text { of External } \\
\text { Funds }\end{array}$ & $\begin{array}{l}\text { One- } \\
\text { Stop } \\
\text { Shop* }\end{array}$ & $\begin{array}{l}\text { Territory } \\
\text { or Tribe }\end{array}$ & $\begin{array}{l}\text { In-house vs. } \\
\text { Contract } \\
\text { Crews } \\
\end{array}$ & $\begin{array}{l}\text { Training } \\
\text { Center }\end{array}$ \\
\hline \multicolumn{12}{|l|}{ Agencies } \\
\hline $\begin{array}{l}\text { AFI, Puerto } \\
\text { Rico }\end{array}$ & $\begin{array}{l}\text { Hot and } \\
\text { Humid }\end{array}$ & $X$ & & $X$ & & $\mathrm{U}, \mathrm{R}$ & & & $X$ & $\mathrm{C}$ & \\
\hline $\begin{array}{l}\text { Housing } \\
\text { Resources } \\
\text { of W. CO }\end{array}$ & Cold & $X$ & $\mathrm{X}$ & $X$ & & $\mathrm{R}$ & & & & $\mathrm{IH}$ & \\
\hline $\begin{array}{l}\text { Lewiston, } \\
\text { ID CAP }\end{array}$ & $\begin{array}{l}\text { Very } \\
\text { Cold }\end{array}$ & $X$ & & $X$ & & $\mathrm{R}$ & & $X$ & & $\mathrm{IH}$ & \\
\hline SKHA, MT & $\begin{array}{l}\text { Very } \\
\text { Cold }\end{array}$ & & & & & $\mathrm{R}$ & $\mathrm{X}$ & $\mathrm{X}$ & $X$ & $\mathrm{C}$ & \\
\hline $\begin{array}{l}\text { HELP of } \mathrm{S} \text {. } \\
\mathrm{NV}\end{array}$ & $\begin{array}{l}\text { Hot and } \\
\text { Dry }\end{array}$ & $X$ & & & $X$ & $\mathrm{U}$ & & & & $\mathrm{C}$ & \\
\hline $\begin{array}{l}\text { CAHRA, } \\
\text { AZ }\end{array}$ & $\begin{array}{l}\text { Hot and } \\
\text { Dry }\end{array}$ & $\mathrm{X}$ & & $X$ & & $\mathrm{R}$ & $\mathrm{X}$ & $X$ & & IH,C & \\
\hline $\begin{array}{l}\text { Opp Co, } \\
\text { WA }\end{array}$ & Mod. & $X$ & & $X$ & & $\mathrm{U}, \mathrm{R}$ & $X$ & $X$ & & $\mathrm{IH}$ & $X$ \\
\hline $\begin{array}{l}\text { CVCAC, } \\
\text { VT }\end{array}$ & $\begin{array}{l}\text { Very } \\
\text { Cold }\end{array}$ & $X$ & $X$ & $X$ & & $\mathrm{R}$ & $X$ & & & $\mathrm{IH}$ & \\
\hline $\mathrm{COAD}, \mathrm{OH}$ & Cold & $\mathrm{X}$ & $X$ & $X$ & & $\mathrm{R}$ & $X$ & & & $\mathrm{IH}$ & $X$ \\
\hline SJHP, FL & $\begin{array}{l}\text { Hot and } \\
\text { Humid }\end{array}$ & $\mathrm{X}$ & $\mathrm{X}$ & $\mathrm{X}$ & $X$ & $\mathrm{U}$ & $\mathrm{X}$ & $\mathrm{X}$ & & $\mathrm{IH}$ & \\
\hline
\end{tabular}




\begin{tabular}{|c|c|c|c|c|c|c|c|c|c|c|c|}
\hline $\begin{array}{l}\text { Selection } \\
\text { Criteria }\end{array}$ & Climate & $\begin{array}{l}\text { Outstanding } \\
\text { Mgmt. Style }\end{array}$ & $\begin{array}{l}\text { High } \\
\text { Energy } \\
\text { Savings }\end{array}$ & $\begin{array}{l}\text { Innovation } \\
\text { and } \\
\text { Efficiency }\end{array}$ & $\begin{array}{l}\text { Multi- } \\
\text { Family }\end{array}$ & $\begin{array}{l}\text { Urban/ } \\
\text { Rural } \\
\text { Model }\end{array}$ & $\begin{array}{l}\text { Leveraging } \\
\text { of External } \\
\text { Funds }\end{array}$ & $\begin{array}{l}\text { One- } \\
\text { Stop } \\
\text { Shop* }\end{array}$ & $\begin{array}{l}\text { Territory } \\
\text { or Tribe }\end{array}$ & $\begin{array}{l}\text { In-house vs. } \\
\text { Contract } \\
\text { Crews }\end{array}$ & $\begin{array}{l}\text { Training } \\
\text { Center }\end{array}$ \\
\hline \multicolumn{12}{|l|}{ Agencies } \\
\hline SDC, WI & $\begin{array}{l}\text { Very } \\
\text { Cold }\end{array}$ & $X$ & & $X$ & & $\mathrm{U}$ & $X$ & & & $\mathrm{C}$ & \\
\hline AEA, NY & Cold & $X$ & $X$ & $X$ & $\mathrm{X}$ & $\mathrm{U}$ & $X$ & & & $\mathrm{IH}$ & $X$ \\
\hline NMIC, NY & Cold & $\mathrm{X}$ & $\mathrm{X}$ & $X$ & $\mathrm{X}$ & $\mathrm{U}$ & $X$ & & & $\mathrm{C}$ & \\
\hline $\begin{array}{l}\text { Lindsay } \\
\text { Park, NY }\end{array}$ & Cold & $X$ & & $\mathrm{X}$ & $X$ & $\mathrm{U}$ & & & & N/A & \\
\hline $\begin{array}{l}\text { Minot, ND } \\
\text { CAP }\end{array}$ & $\begin{array}{l}\text { Very } \\
\text { Cold }\end{array}$ & $X$ & $X$ & $X$ & & $\mathrm{R}$ & & & & $\mathrm{IH}$ & \\
\hline
\end{tabular}

*One-stop-shop may include weatherization plus health and/or housing rehabilitation 


\section{The Human Story}

An ancillary purpose of this report is to get at the human stories behind the numbers and statistics of the WAP. Each local agency expresses its philosophy about weatherization in how it carries out its activities on a day-to-day basis. Presented in the order in which the site visits were conducted (between May 2011 and July 2012), the case studies show the challenges of operating weatherization programs in many states and territories, the difficulties of ramping up (and down) production during and after the ARRA period; the dedication and imagination of hundreds of WAP employees; the safety and comfort of newly weatherized buildings; and the ways in which WAP employees work to improve their clients' lives in more than just weatherization. In addition, the studies describe how agencies cope with Federal regulatory requirements, particularly the Davis-Bacon Act rules put in place during ARRA, which set worker pay scales at prevailing local levels, and the ventilation rule known as ASHRAE 62.2 that has recently become a requirement in the Program.

The work of the weatherization assistance programs profiled in this report has implications for the nation at national, state, county, community, and personal levels. On the national scale, saving energy translates into less reliance on fossil fuels and lower emissions of air and water pollutants. At the state level, WAPs are able to help each other with state-specific weatherization solutions and innovative ideas. At the community level, as neighbors on the weatherization crews help their neighbors, communities build the interpersonal ties that keep them healthy, independent, and in less need of government assistance. Finally, on a personal level, American citizens whose lives are lived "on the edge" of financial stability and physical safety find themselves warmer, more comfortable, less ill, and physically safer as a result of weatherization assistance provided by WAP. Children and older people with respiratory vulnerabilities such as asthma or allergies have to go to emergency rooms less frequently, saving taxpayer dollars. Lastly, crews and contractor staff learn state-of-the-art skills that can improve their lives. 



\section{PUERTO RICO}

\subsection{INTRODUCTION}

The series of case studies begins with Puerto Rico, which is atypical of the other cases in that Puerto Rico is distinct politically, environmentally, socially, and culturally from the other states and territories contained in this report. Yet at the same time, Puerto Rico's weatherization program, which began only in the ARRA period, embodies many of the same challenges that were faced by other programs as they were organized and implemented.

The island of Puerto Rico is an unincorporated territorial possession of the United States. Located in the northeastern Caribbean Sea, Puerto Rico is home to nearly 4 million people and has a hot, humid tropical climate with an average temperature of about 85 degrees Fahrenheit (28 degrees Celsius) and an average rainfall of about 66 inches or $168 \mathrm{~cm}$. Puerto Rico's climate makes weatherization practice quite different from that in colder-weather states: not air sealing (or any shell measures as they are not cost-effective), but air ventilation - getting as much air through the house as possible during the day - is the priority in the hot, rainy climate.

The people of the densely populated island have an average annual income of between $\$ 18,000$ and $\$ 19,000$, making many eligible for low-income assistance of various sorts.

The Weatherization Assistance Program, as noted, was introduced in Puerto Rico at the beginning of the ARRA period; until that time Puerto Rico had not had a strong tradition of environmentally sustainable home energy use. Recycling was rare, and there were few solar water heaters or energy-efficient appliances available.

\section{Case Study Description}

In March 2009, The Department of Energy's (DOE's) definition of "state" was modified in a Final Rule in the Federal Register to include the Commonwealth of Puerto Rico along with the other four U.S. Territories (Guam, the U.S. Virgin Islands, the Commonwealth of the Northern Marianas Islands, and American Samoa). The inclusion of the territories is consistent with modifications made to Section 411(c) of the Energy Independence and Security Act (EISA) of 2007. The final rule extended federal regulations and guidance of the Weatherization Assistance Program (WAP) to these U.S. territories under both regular and ARRA program years, with the principal exception being that of the applicability of DavisBacon Act rules, which provide for worker pay scales at prevailing local levels and which were deemed inapplicable to U.S. Territory programs.

\subsection{PROGRAM OVERVIEW}

Starting a program of the magnitude of Puerto Rico's necessarily involves a number of challenges, but offices of the Department of Energy (DOE), the National Energy Technology Laboratory (NETL), and Simonson Management Services (SMS) provided ongoing technical support by arranging on-site visits and phone conferences among the Grantee, the Subgrantee, DOE administrative staff, Project Officers, and Technical Assistance team members. This support continues to help in overcoming obstacles to program implementation.

\section{Organizational Structure}

After eligibility for DOE's weatherization program was established in 2009, the government of Puerto Rico had to develop an organizational process for program management and delivery. As a natural 
resources agency, the territorial office of the Energy Affairs Administration (AAE in Spanish) was designated as the primary Grantee, but at the time of the case study, Grantee status was slated to move to Puerto Rico's Department of Economic Development. Although WAP Subgrantees are often selected based on Community Action Agency (CAA) status, the Infrastructure Financing Authority (La Autoridad para el Financiamiento de la Infrastructura, also known as AFI) was designated as the Subgrantee to oversee all of Puerto Rico's ARRA-funded projects. Thus, AFI is the sole Subgrantee, but it is also a state agency. Law \#8 was passed by the Puerto Rican government and signed by the governor in 2009 designating AFI as the sole Subgrantee; administrative funding was split with AAE.

Although AFI is designated as the Subgrantee, all positions are contracted out, even that of the weatherization director. Thus, 16 contract technical coordinators report to the weatherization director and manage all of the weatherization field activities. Like the technical coordinators, all auditors, weatherization measure installers, and inspectors are also contractors. At the time of the site visit interviews during May 2011, 70 to 80 percent of the AFI contract professionals were employed full-time by the WAP. Figure 2.1 shows the organizational structure of the WAP program in Puerto Rico.

It should be noted that with the assistance of the Department of Energy, NETL, and SMS, both Puerto Rico's Energy Affairs Administration (AAE) and the infrastructure financing authority (AFI), developed their own models for program philosophy and delivery, relying neither on the infrastructure nor the delivery-system models employed by other U.S. WAP agencies. Time had to be spent on developing the local model, but because Puerto Rico has a tropical marine climate unlike that of other states, there were not many models to replicate, so the support teams at AAE and AFI had to develop a program attuned to the technical needs of the island's housing stock and culture.

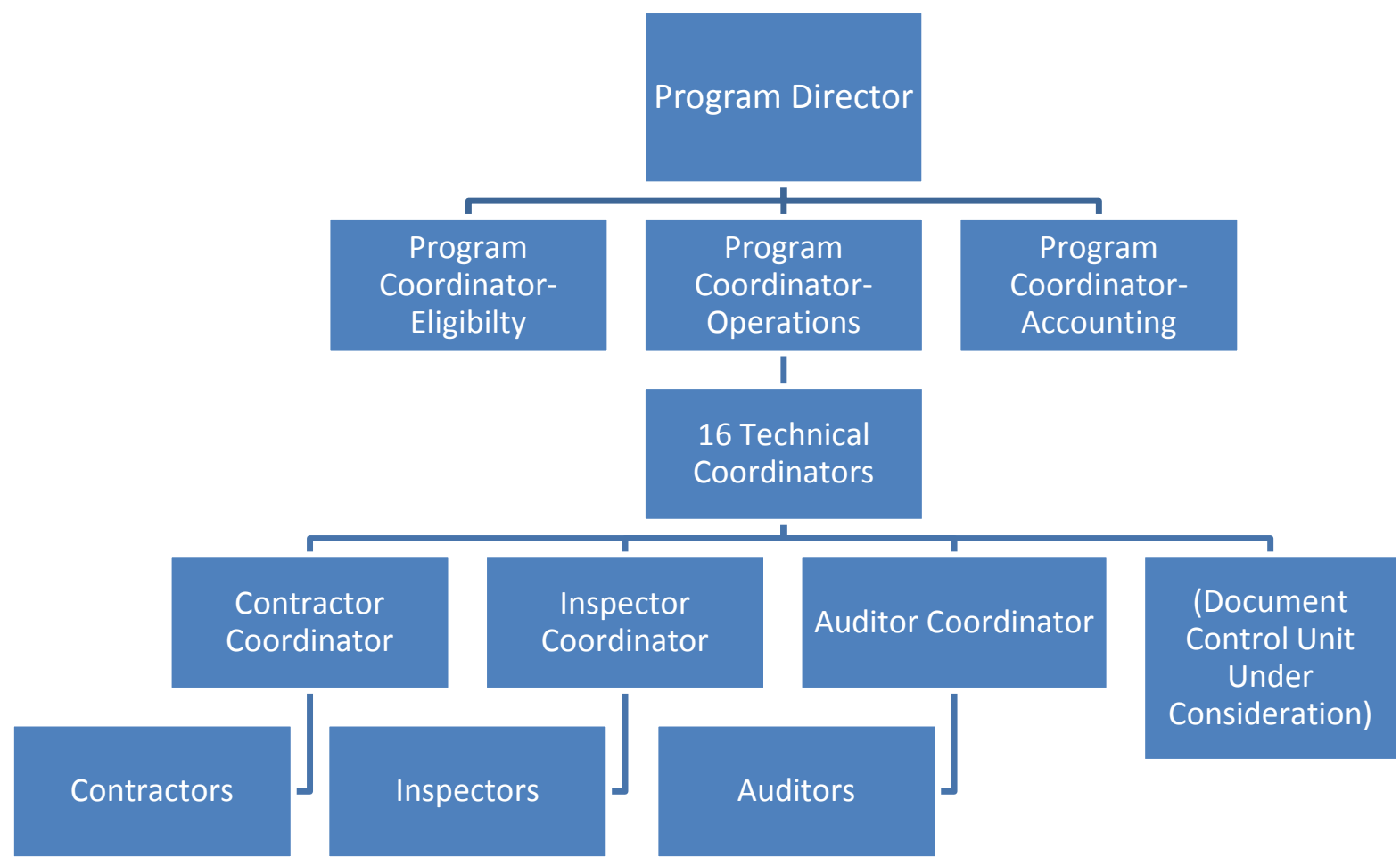

Fig. 2.1. Puerto Rico's Weatherization Assistance Program Organizational Structure (under AFI). 
A state the size of Puerto Rico, with a population of almost four million people, would normally have five to ten Subgrantees geographically dispersed state-wide to deliver a program of this size, as local Subgrantees would be more accessible to potential clients, and weatherization workers would also live in the community, cutting down on travel times and costs.

There were several compelling arguments, informed by consultation with professionals within the weatherization network, to give the Puerto Rico work to a single Subgrantee. First, prior to the WAP program's startup in 2009-2010, there had been no existing network of potential non-profits capable of providing weatherization services on the island. Secondly, AAE wished to develop a program that could be consistently implemented island-wide. It was anticipated that because vigorous debate is a cultural norm in Puerto Rico, it might be a significant challenge to quickly build consensus about program delivery if there were multiple Subgrantees. A third factor was that having AFI as the sole Subgrantee was relatively easy to expedite since AFI already existed, was already part of the state government, and could coordinate professional services quickly. ORNL staff observed on-site the efficiency and streamlined qualities of program delivery and was able to confirm the wisdom of this approach in conversations with the DOE Project Officer.

\section{Challenges with Puerto Rico's Startup of WAP}

One major challenge that AFI faced was in determining the resources necessary for program delivery. Because no one had been involved in weatherization prior to the American Recovery and Reinvestment Act of 2009, it took time to determine how many people at both the Grantee and Subgrantee levels would be needed to manage the program. Key production time was lost during the first year as a framework for the program was established. The first unit was started on Earth Day, April 22, 2010. As production increased and experience was gained, the number of technical coordinators grew from 6 to 10 to the current 16. One of the coordinators now manages the rest of the coordination team.

Another challenge was acquiring the right mix of specialized and general weatherization contractors, particularly in each of the four specialized measure categories:

- Refrigeration (as of the site visit, there was one contractor in this category, but AFI anticipated an
Primary WAP Start-Up and Production Challenges in Puerto Rico

- No weatherization program existed resulting in program creation from scratch. Additionally, there was no one on staff at DOE or in Puerto Rico who had been involved with starting a new WAP program. The new program required special attention from DOE consisting mostly of strategic planning and technical assistance.

- First year was spent establishing framework for the program cutting into key production time. First unit was started on Earth Day, April 22, 2010.

- Administrative costs were split between the Grantee and Subgrantee posing budgeting challenges.

- It was difficult to determine number of staff needed at both Grantee and Subgrantee levels, as well as how many specialized and general contractors should be secured.

- Determining number of projected units was a challenge as a result of initial funding allocation formula error as it did not include regular program year funding.

- The Subgrantee had to provide evidence of funding to the specialized contractors to motivate them to increase inventories.

- Solar Hot Water Heaters had OG100 certifications not OG300 certification required per WAP guidance. A waiver was necessary until the OG300 certification could be obtained.

- Addressing Refrigerator contractor non-compliance with timely invoicing resulting in new contract with new contractor. In addition the recycling documents for the removed refrigerators were not what they should have been with the first contractor.

- Additional training on WAP guidance was required on the installation of allowable measures (e.g., repairs not justified by energy savings, such as extensive electrical work). Additional training on WAP guidance was completed. 
increase to three by July 2011);

- Air conditioning (as of site visit, there was one contractor in this category but AFI had issued a Request for Proposal (RFP) to add more);

- Solar water heating (SWH) (as of the site visit, there were two contractors in this category)

- General Contractors (Installation of compact fluorescent lamps (CFLs) and low-flow showerheads, as well as some health-and-safety electrical work).

A third challenge had to do with introducing the concept of weatherization to the island. As has been stated, Puerto Rico was not very environmentally "green" at the beginning of the ARRA period. Recycling rates were low and few homes had energy-efficient appliances or solar water heaters.

Consequently, when AFI began to determine that thousands of income-eligible homes would need solar water heaters and Energy Star-rated refrigerators and air conditioners, the desired units were not locally available for purchase. Suppliers of these appliances were skeptical at first, so AFI had to produce evidence that it was funded and ready to sign contracts before appliance suppliers would increase their inventories.

Additionally, budgeting challenges existed because administrative costs had to be split between the Grantee and Subgrantee, and an error in the initial funding allocation formula created difficulty in determining the number of projected units, as regular program year funding was not included.

Puerto Rican Household Energy Consumption:

- Most elderly people native to Puerto Rico do not use hot water for bathing, as they lived many years without access to hot water technology.

- Some schools operate in shifts, so some children are at home during the morning/early afternoon before starting their school shift in the later afternoon. This may lead to increased energy consumption during the day.

- Wall unit air conditioners are primarily used in bedrooms and at night only to allow for comfort while sleeping.

- "Miami" or French style windows are opened during the day to allow for maximum airflow through the home (see photos under Unit Summaries).

- Ice is retrieved from the freezer throughout the day to combat the heat with ice-cold beverages.

- Clothing is usually line-dried, both inside and outside homes, especially in the drier regions of the island regardless of whether the family has a working electric clothes dryer.

- Long, covered patios provide cool spaces for occupants to spend time outdoors.

With all these organizational and administrative challenges, there were also minor issues that created opportunities for "lessons learned":

- The solar water heaters available had OG100 (rating only for the collector) certifications, not the OG300 (rating for complete turn-key system) certification required per WAP guidance. A waiver was necessary until the OG300 certification could be obtained.

- Because the refrigerator contractor did not provide timely invoicing or proper recycling documentation, a new contractor had to be signed up.

Additional training was needed on how to determine when repairs necessary to install measures, such as extensive electrical work, would be allowed. 


\subsection{PHILOSOPHY AND APPROACH}

As every particular place has its own particular weather, every locale poses unique challenges for weatherization. Households in hot climates typically use much less energy than the average U.S. household, but electricity can cost much more on islands, resulting in a nearly comparable home-energy cost burden. One of the missions of WAP in Puerto Rico (and of the program in general) is to help program-eligible residents permanently lower their energy bills by making the existing housing stock more energyefficient. Interestingly, initial state level statements pertaining to the development of WAP in Puerto Rico described a mission targeting not the extremely poor (i.e. unemployed poor) but the working poor. Perhaps this was due to that sector's increased energy consumption behavior or as a strategy to prevent deferrals or "walk-aways" resulting from structural issues associated with housing stock of those living at a greater level of poverty. Additionally, those living in extreme poverty may also be more transient, so they may not be living in the home when the auditor or crew arrives to complete the weatherization work.
Weatherization in Tropical Marine Climates: What Makes It Different?

- Ample sunlight and wind mean that many housing units in the territories could be fitted with renewable energy technologies. SMS provided technical assistance addressing this issue.

- Moving air through the home is a high priority, so air sealing and insulation are not recommended. Therefore, opportunities to save energy mostly involve replacement of inefficient incandescent lighting, air conditioners and refrigerators; and improved baseload measures, which involves the installation of low flow plumbing fixtures and more efficient domestic water heaters, especially solar water heaters when appropriate.

In a hot climate, energy use naturally focuses on base-load electric measures dealing with household appliances and cooling systems, both of which tend to be less costly than heating system replacements or installations. For example, approximately 24 percent of home energy use in Puerto Rico is attributed to air conditioning. However, the philosophy of the Puerto Rico program is that if there is no existing working AC unit of appropriate WAP standard size, the unit will not be serviced or replaced, nor will a new one be installed. The thought is that an AC-less home is already saving energy without the use of this technology and the program does not want to increase energy consumption in any way, even if the increase could be offset through the installation of other energy-saving measures.

Again because of the climate, heating system expenditures are not allowable in Puerto Rico's program, as there is only an average 20-degree variation in temperature throughout the year and installment, servicing, or replacement of heating systems is not cost-efficient. As a result, the per-unit cost of retrofits in the tropical and sub-tropical marine climate zones of this U.S. territory has been lower than initial projections, allowing for an increased number of local residential units to be weatherized.

Similarly, insulation is not generally a priority in Puerto Rico because, as noted above, the goal is to move air in and out of a house rather than keep it in or out. Because of the louvered windows and worries about mold and humidity build-up, tight air sealing is neither possible nor advisable. Thus, auditors in Puerto Rico do not conduct blower door tests, and insulation is rarely installed.

Because air sealing is not an issue, audits take less time and auditors need less extensive training since they do not have to understand the science behind building construction. The weatherization process is different, too, requiring much less time to be spent by traditional weatherization crews in each home. Indeed, the general contractors receive only about $\$ 350$ per home to install the various energy-efficiency measures (e.g., CFLs and low-flow showerheads).

In Puerto Rico, services are not delivered through a single weatherization crew but through separate contractors. The technical coordinators have a goal to close out a job in 90 days, but this goal is not 
frequently met because of the need to coordinate up to six different weatherization-related visits: an initial visit with the auditor as well as visits from the general contractor, the solar water heater contractor, the refrigerator replacement contractor, the AC servicing contractor, and then a final visit from the inspector. A major challenge for the technical coordinators is to schedule the deliveries of the various weatherization components. This is in stark contrast to the more common crew-based programs that have specialists inhouse.

\section{Weatherization Delivery}

Out of the island's total population of approximately 4,000,000 people, between 500,000 and 700,000 households are income-eligible for weatherization assistance. Although the program application process was on a first-come, firstserve basis, a large percentage of households fell into highpriority categories, especially the elderly, as reported in DOE's Performance and Accountability for Grants in Energy (PAGE) reporting system.

To date, applications for weatherization services through WAP have been opened in two phases. Approximation phase was initiated when, due to an initial formula error, $\mathrm{AE} / \mathrm{AFI}$ received additional funding for low-income weatherization, increasing WAP ARRA funds from $\$ 48.9$ million to $\$ 65.3$ million, enough to service an additional 8,000 eligible units. The average cost of weatherizing a housing unit is currently around $\$ 4,500$. Although the WAP goal for units to be completed currently rests at 8,600 , the Governor of Puerto Rico has announced a goal of 10,000. It should be noted that at the time of the site visit, few renteroccupied homes and no multifamily units had been weatherized.

A system was established to set up the distribution of the program around the island. Call centers in seven regions asked pre-qualifying questions of potential weatherization client households. If a household was pre-qualified, then an interview was set up with the householder to accept WAP services. The first phase of application collection was set up by each municipality, with a minimum of 100 recipients per municipality. However, if only 80 eligible households applied, the remaining 20 slots were shifted to other municipalities within that region.

AFI did some initial advertising of the program through the use of public awareness campaigns, but after a few homes were successfully weatherized, word quickly spread throughout the island about the program. Neighbors told neighbors, relatives told relatives, and workers told their peers about the program. Ultimately, AFI received thousands more inquiries than could be accepted.

\section{Puerto Rico's Weatherization} Wish List:

The wish list generated for this section is a compilation of responses sought from program recipients, staff and professionals from within the weatherization network in Puerto Rico, DOE and SMS staff, and from the literature published by the government of Puerto Rico providing suggestions for future WAP allowable costs.

- Cool Roofs: to reduce solar gain

- Refrigerators with Through the Door Ice Dispensers: to address household resistance to refrigerator replacements without this technology

- Power Strips: to reduce the phantom load for baseload appliances

- Fuel Switch: from electric to gas cooking stoves

- Using a Combination of Renewable Technologies

- Partnering with Other Community Resources in the Industry: for a more comprehensive retrofit

- Reduce the \# number of Contractors: less time in homes, fewer contracts to monitor, better coordination, more cost effective. This will be difficult as it will entail a change in the infrastructure currently in place.

- Only Install 8,10,12, kBTU AC Units

- More Time to Reach Production Goals: funds extending steady funding over a longer time period

- Annual Training Conferences: include tropical marine climate topics

- Evaluation of PREAT as an Effective Auditing Tool: At the time of the Case Study PREAT was not an approved DOE auditing tool

- AC Metering Electric consumption evaluation: As an evaluation to assist with program guidance design 
ORNL interviews with program recipients in the field confirmed the success of informal social networks in promoting the program. AFI staff also noted that programs that do not receive this stamp of approval from within the social networks are often not embraced by the public. An AFI staff member believes the most successful strategy for engaging the public and receiving applications was simply the implementation of the program itself. "Once members within the social network received word that the program was legitimate, they then began to trust in the program," the staff member reported. To meet the increased demand for services, AFI efficiently implemented intake procedures in the seven regional offices located around the island.

At present, households are ineligible if they have already utilized the program. This rule is adhered to despite the unpredictable tropical marine climate, which is prone to flooding and other damage from hurricanes and tropical storms. Although the program is new and this issue had yet to be of concern, the question was raised within the program's administration whether or not waivers could be granted and homes re-weatherized in case of future natural disasters.

\section{Training}

An initial one-week training session was conducted by an Energy Coordinating Agency team from Philadelphia. As the majority of the workforce for AFI has been trained, after this session, weatherization trainings were offered on an as-needed basis as refreshers in certain areas. The primary surprise observed in the field, but that was not addressed in the trainings, was electrical wiring and breaker problems that could lead to home fires. During our discussions, various staff also suggested that trainings incorporate flood and other water issues created by hurricanes and tropical storms and the training curriculum could be better tailored to these climate issues.

\section{Weatherization Audit}

In other weatherization assistance programs, home-energy audits are often performed by trained professionals using computerized audit tools such as the National Energy Audit Tool (NEAT), which are capable of evaluating an individual home, describing its physical characteristics and energy-using components, and generating a prioritized list of recommended measures. Upon determining that the unit meets health and safety standards, the audit is conducted and is further documented using digital images; it includes guidance and instructions for the contractors installing the measures. For example, the auditor will estimate the amount of copper needed for the solar water installation and direct where to put the piping and the roof unit. A questionnaire is also administered to the occupant to gather information on how the household uses energy as well as any health and safety needs.

AAE quickly realized that conventional computer audit tools such as NEAT were not suited for Puerto Rico's tropical climate, so AAE developed its own tool, PREAT (for Puerto Rico Energy Audit Tool), which, like NEAT, is a computerized audit tool that helps auditors identify measures that can be installed to meet the savings-to-investment ratio (SIR) requirement. ${ }^{4}$

At the time of the field observations there appeared to be continuing confusion as to whether or not PREAT had been approved for use. Although the DOE Project Officer was aware of the use of PREAT it not approved for use by DOE. However, AAE and AFI continued using the PREAT auditing tool while DOE reviewed the audit's accuracy. However, the confusion did not appear to deter either AAE or AFI from using the PREAT auditing tool. They reported that if they used the priority list from NEAT, they

\footnotetext{
${ }^{4}$ The SIR is the present value of the expected energy cost savings of a measure divided by the cost of the measure. Only measures that have a SIR of 1.0 or greater are allowed to be installed in homes.
} 
would be bound to install measures that were unnecessary, in AAE's view, in Puerto Rico; for example, they would have to replace unused or broken air-conditioning units.

\section{Weatherization Measures}

On its site visit to Puerto Rico, the ORNL team visited nine homes in the field and found that the difference in climate resulted in a Puerto-Rico-specific pattern of weatherization measures installed. Weatherization measures for Puerto Rico fell into the following six categories:

- Solar water heaters with OG 300 Certification

- Wall air conditioners (either replacement or servicing of)

- Refrigerators (either replacement or servicing of)

- Measures to reduce baseload electricity use, including CFL light bulbs

- Low-flow showerheads

- Electrical health and safety (raising outlets above flood level, replacing frayed cords, etc.)

Although additional measures, such as reflective window films and power strips, were described in Puerto Rico's State Plan, it was not observed that these measures were actually deployed. The team's guides explained that reflective films do not work with the louvered window style of Miami and French windows and that the use of power strips was not allowable.

Approximately 70 percent of weatherized units receive either a flat plate collector or evacuated tube solar water heating system. Every home visited as part of the case study had had a new solar water heater installed on the roof. They were only installed on homes with concrete roofs, however, because AFI was not able to verify that other types of roofs (e.g., wood or metal) were structurally sound enough to support both solar water heaters and the workers on the roofs doing the installation; however, most of the singlefamily detached homes seen on the site visit had been built with concrete construction, to withstand hurricanes. It should be noted that on DOE monitoring trips and technical assistance visits completed by SMS, some concrete homes were deemed structurally unsound because the concrete was eroding and exposing interior rebar.

Decisions about whether to install air conditioner units were somewhat more complex. Unused air conditioners were not replaced, as their installation would not save any energy even if the replacement could be considered a Health and Safety issue (See Unit 9). Also, only air conditioners of 8,000 to 12,000 BTUs in size were replaced with Energy Star rated units, per Puerto Rico's state plan. The AAE and AFI staff said that this size limitation turned out to be a problem, as they found numerous homes with bigger $\mathrm{AC}$ units that could have been replaced, and that the size of the units in these homes was appropriate. They planned to raise the limits on this specification in a future plan. 
Post-weatherization inspections are completed by a trained professional, but never by the same person who audited the unit in the first place. At first, inspectors reported that contractors were incorrectly orienting the solar HW units or inadequately anchoring the solar HW units to roofs. However, with further contractor training, this problem has now been largely resolved.

Initial DOE/SMS inspections highlighted concerns with electrical issues, improper installation of through-the-wall A/C units, and showerheads. During more recent reviews, DOE/SMS inspectors were not observing problems with solar installations. Occasionally, however, a client reports an issue that turns out to be a problem with education, not installation. For example, one householder complained of running out of hot water. The problem turned out to be that the electric backup was not hooked up. It was suggested that this issue could be a good client education topic and contractors should at least tell households that the hook-up is available to get more hot water. Additional education topics could include time of use for optimal availability and storage capacity of the systems. Another early problem was the installation of the wrong CFL bulbs outdoors where there was no protective covering to keep them from getting wet.

\section{Health and Safety}

AFI keeps expenditures to a strict limit of $\$ 600$ per home for health and safety measures, such as replacing frayed electrical cords, fixing electrical outlets or ground interruptions, or addressing the use of extension cords used with heavy appliances such as refrigerators. At times, unsafe light fixtures are also replaced.

AFI teams are conscious of home construction dates (especially prior to 1978) as they pertain to the presence of lead in homes. As a rule, AFI does not do any work that might disturb lead in a home. For example, windows are not replaced in homes that are assumed to contain lead based on the age of the home, and holes are not drilled in walls or ceilings. Window or wall AC units are only replaced if no work is needed to increase the size of the hole in the wall for the unit. Households are always informed about any potential lead risk.

\section{Client Education}

The site visit guides informed the team that client education about energy consumption behavior is done at each phase of weatherization, therefore being reinforced multiple times. The auditor has the main responsibility for explaining how the Program works, what the benefits of saving energy are, how the audit is conducted, its results, potential measures to be installed, and other ways that clients can save energy. Auditors leave several informational brochures for clients to read after their visit, including 
information about dealing with mold, disposing safely of CFL bulbs, and how changing energy consumption behavior can improve their quality of life. The post-weatherization inspector also reinforces the information given by the auditor. Between those two points in time, contractors who install new solar water heaters, air-conditioning units, and refrigerators also explain the energy-efficiency features of these new appliances and how to use and maintain them. All the clients we interviewed reported satisfactory client education experiences. Beyond the standard information about weatherization, the auditors, inspectors, and contractors tailor their advice to the tropical environment of the households, helping householders understand how to achieve persistent energy savings by actions like the following:

- Opening bedroom doors in the early evening to allow for air flow before turning on the $\mathrm{A} / \mathrm{C}$ unit and closing up the room

- Not placing the refrigerator next to the stove

- Washing full rather than partial loads of laundry

- Unplugging appliances when not in use

- Monitoring the refrigerator thermostat

- Using natural light and air during the day

- Purchasing outlet strips to reduce phantom $\operatorname{load}^{5}$

\section{Walk-aways and Deferrals}

With respect to WAP-provided services, occasionally the projected work cannot be completed because of a problem on the client's side. These situations are called "walk-aways" and "deferrals." AFI makes a distinction between the two. In a deferral, something in the home may need to be repaired before the home can be weatherized; once they are enrolled in the Program, householders are allowed 30 to 60 days to fix problems. Although deferrals occur primarily because a house is structurally unsound and cannot be weatherized "as is," "walk-aways" occur when the auditor finds one of any number of unacceptable conditions in or relating to the home. These include for-sale signs in front (indicating that the householder is taking advantage of the WAP to improve the value of the home before selling), excessive mold, illegal electricity connections, very bad electrical wiring, or a roof in poor condition. Examples of "walkaway" conditions that DOE observed on monitoring trips included crumbling concrete with exposed rebar and "live" wired light fixtures in the middle of a roof leak.

Because there was no clear protocol in Puerto Rico for determining walk-aways and deferrals, SMS assisted with writing policy on these issues, as there appeared to be a high number of both deferrals and walk-aways.

Additionally, it was a problem for auditors when they would have to drive an hour to a unit, but the householder would then refuse services so the auditors would not get paid for their time. DOE and AFI worked out a solution establishing a set fee for deferral homes.

AFI also added a screening process to the telephone application, helping to cut down on wasted time spent visiting homes that could be quickly screened for deferral or walk-away issues.

\footnotetext{
${ }^{5}$ Phantom loads are those that draw electricity while not in use.
} 


\section{Client Concerns}

The DOE team reviewed the history of complaints with the Program, the majority of which concerned program recipients calling to check on their status and wondering why the process was taking so long, especially if a neighbor or acquaintance's home had already been weatherized. Other complaints involved a perception of faulty equipment (such as leaky solar water heaters-leaks which often were simply part of the overflow system), and requests for items or services not allowable under WAP guidance or regulations, such as side-by-side refrigerators with through-the-door ice dispensers. However, only a few households have exchanged both a fridge and freezer or multiple refrigerators for a bigger unit, so this was not seen as a significant source of complaint.

A more significant issue with the Program is that clients may not see immediate savings because of the method by which their bills are calculated. There is only one utility company on the island, the Puerto Rico Electric Power Authority (PREPA). A public corporation founded in 1941, it is heavily dependent on oil for electricity generation. Electric bills are calculated by means of frequent estimates (estimados) as opposed to meter reading (lectura) of actual energy consumption. Estimation cannot catch changes in home due to weatherization, so customers call to complain when they do not see any reduction in bills. One customer was accused by PREPA of tampering with the electric meter and stealing electricity because the company didn't believe the significant reduction in energy savings. PREPA replaced the meter twice before accepting the client's explanation that weatherization had so significantly reduced energy use.

Inaccurate estimation appears to be a problem and households often have to appeal to the PREPA to read the meter after their homes have been weatherized to receive the benefit of energy cost savings.

This issue will need to be addressed for billing analysis purposes as well to accurately document energy savings attributed to WAP in Puerto Rico.

\section{Monitoring and Verification}

AFI's client files have been inspected by both DOE and AAE and were found to be complete, with photo documentation of everything related to projects. Indeed, it had been noted during earlier DOE monitoring trips that AAE and AFI were told that they were collecting too much documentation to support billing invoices and that information in files was duplicated, thus interfering with production goals and representing a time-management issue. However, it was reported to the ORNL team that suggestions made on these previous monitoring visits had been heard and responded to by both AAE and AFI, with the result that subsequent monitoring visits saw satisfactory production levels. Although, as noted, it took a year for AAE and AFI to establish their framework for WAP, both agencies were commended by SMS staff for having the foresight to establish a good program before attempting implementation.

The ORNL team accompanied the DOE Program Officer to visit nine units: client files were checked, and no discrepancies were found between the files and what had actually been installed.

\section{Integration of Services with Other Agencies}

The WAP program in Puerto Rico is not tied to a larger social services network, and there is no clear policy about referrals to other social-service agencies when, for example, a house weatherization must be deferred for health-and-safety issues in households with children or elderly people (e.g. vulnerable populations). There seems to be less of a governmental network in Puerto Rico than in the mainland states, where community action agencies generally operate a myriad of programs or where weatherization programs are in communication with other community or social services agencies that can deal with 
issues of concern but that are outside the scope of WAP. One AFI staff member reported, however, that homes observed to have a serious safety hazard are referred to the local offices for Puerto Rico's Department of Housing and Urban Development.

\section{Leveraging and Collaborations}

The current Program in Puerto Rico does not receive any leveraging money from utilities or other sources. Thus, weatherization activities for income-eligible households are likely to be much curtailed after ARRA.

\subsection{LOOKING TO THE FUTURE POST-ARRA}

Discussions about post-ARRA strategies for Puerto Rico's WAP yielded few options for redressing the significant funding reduction. While ramping down the Program will certainly be an issue for AAE and AFI, current production activities have moved this topic to a lower priority. Both AAE and AFI expressed a desire to get the ARRA period extended to allow them to expend their ARRA funds in the most efficient manner.

As the Program ramps down, there will be job losses; however, this prospect did not appear to generate anxiety among the professional staff within the weatherization network, as the staff's educational levels and the availability of funds in other government projects allow the professional staff to move from one job in their field to the next without much trouble. AFI staff reported no preparation for ramp-down at their level and said that no retraining is offered, other than standard weatherization training.

\section{Post-ARRA Leveraging}

Prospects for post-ARRA leveraging do not seem bright. No one who was interviewed believed that the Puerto Rico Electric Power Authority could be convinced to provide leveraged resources; weatherization and other energy-efficiency efforts do not benefit a power company's bottom line, and in Puerto Rico, there are no established public resource funds for weatherization services such as exist in other states.

\section{Role of WAP and ARRA in the Future of Energy Efficiency Efforts in Puerto Rico}

During Puerto Rico's most recent gubernatorial election (2008), candidates spoke of a need to focus on energy efficiency and to move away from dependence on fossil fuels; some attempted to promote renewable energy systems. Until WAP, energy efficiency had been a topic of concern at both the government and household level-householders in Puerto Rico had wanted to do something about home energy consumption, both to reduce the percentage of income used for energy and to deal with the increase in public utility rates for electricity — but the number of householders that wanted to weatherize far outmatched the resources available at the time. WAP and ARRA funds have considerably reduced the discrepancy between the numbers of people who wanted to weatherize their homes and the number who actually could do so. WAP staff at the AAE and AFI agreed that the Program has offered people what they were seeking, as was also evidenced by the volume of applications received at call centers in both phases of the Program.

\subsection{SNAPSHOTS}

\section{Nine Weatherized Homes in Puerto Rico}

Unit 1: This occupant-owned home is of typical Puerto Rican concrete construction. (See Figures 2.2-5). One side of the home has an open patio, where the occupant spends much time. Washer and dryer are 
outside, the home has louvered Miami-style windows and is all-electric. This unit received standard WAP measures for Puerto Rico's program: a solar water heater, a new refrigerator, a window AC replacement in the bedroom, a low-flow showerhead, and new CFL bulbs. The observed utility bill showed about 20 percent $\mathrm{kWh}$ savings but no cost savings due to significantly heightened electricity rates.

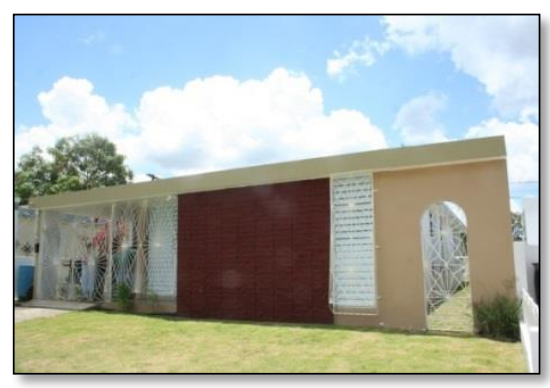

Fig. 2.2. Ponce Region Unit 1

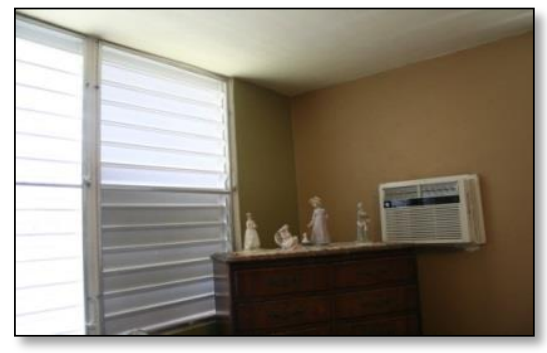

Fig. 2.3. AC unit

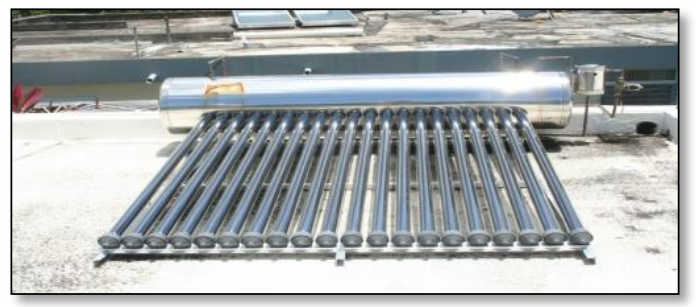

Fig. 2.4. Solar Water Heater

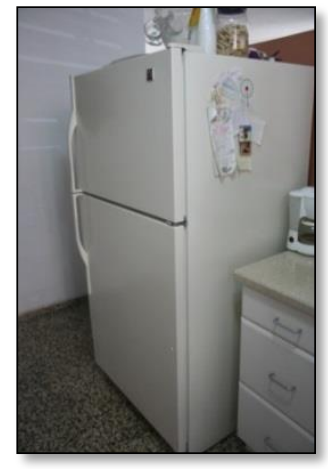

Fig. 2.5. New refrigerator 
Unit 2. This home, occupied by an elderly couple, was an example of the practice of utility estimation (rather than meter-reading) being a problem (the electric meter did not actually work). Contractors installed an energy efficient ceiling fan to assist with air-flow through the home during the day. The home had French style glass windows instead of aluminum Miami windows. Unit 2 received the following standard WAP measures for Puerto Rico's program: a solar water heater, a refrigerator replacement, a window AC unit in the bedroom, a low-flow showerhead, and new chandelier with CFL bulbs (See Figures 2.6-9).

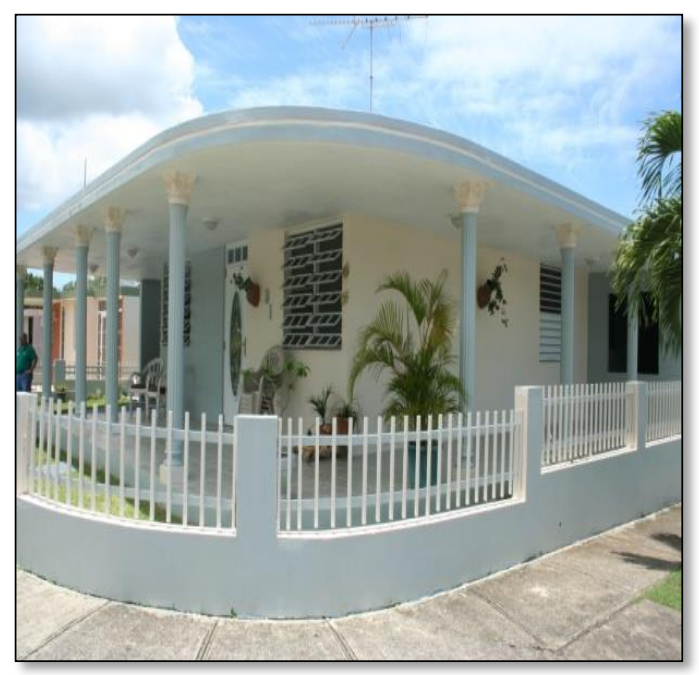

Fig. 2.6. Ponce Region Unit 2

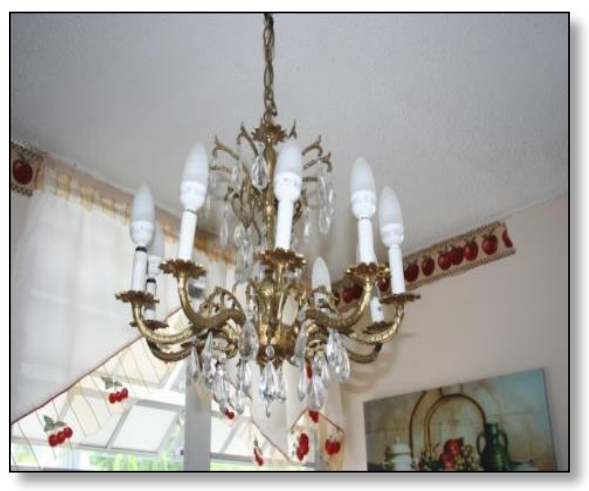

Fig. 2.7. Chandelier CFLs

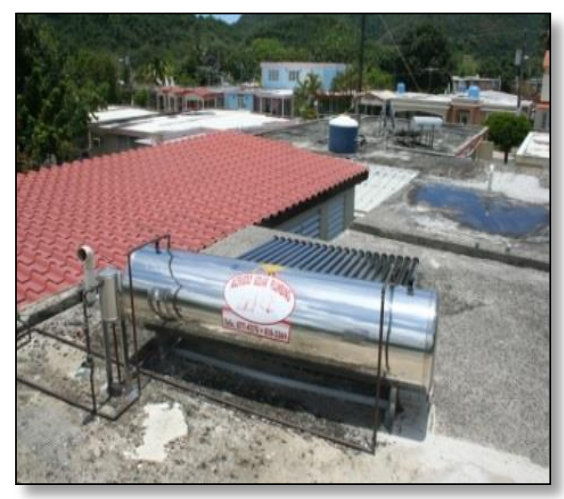

Fig. 2.8. Roof Solar HW

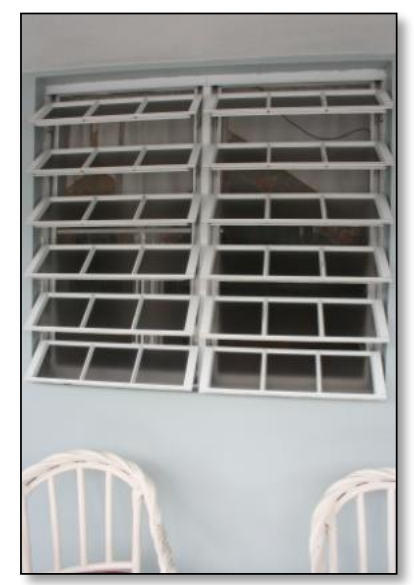

Fig. 2.9. Louvered Windows 
Unit 3. The occupants of this unit are a couple with two small children. The father is a high-school teacher and the mother home-schools the children, one of whom, 7 years old, was present for the audit and has taken a great interest in recycling and energy issues. The mother heard about the Program from a friend; she then spread the word to her own friends. Unit 3 received the following standard WAP measures for Puerto Rico's program: a solar hot- water heater, AC servicing, low-flow showerheads, and new CFLs (See Figures 2.10-13). Note: No new refrigerator was installed as the family had recently installed a new one.

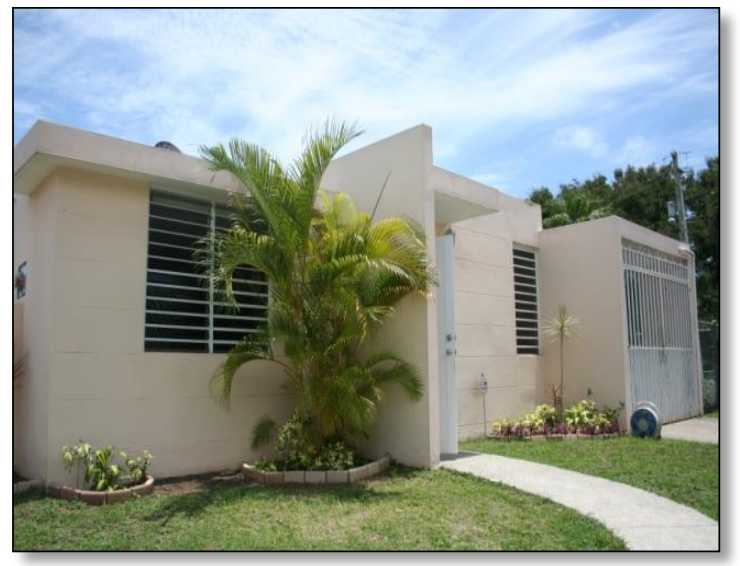

Fig. 2.10. Ponce Region Unit 3

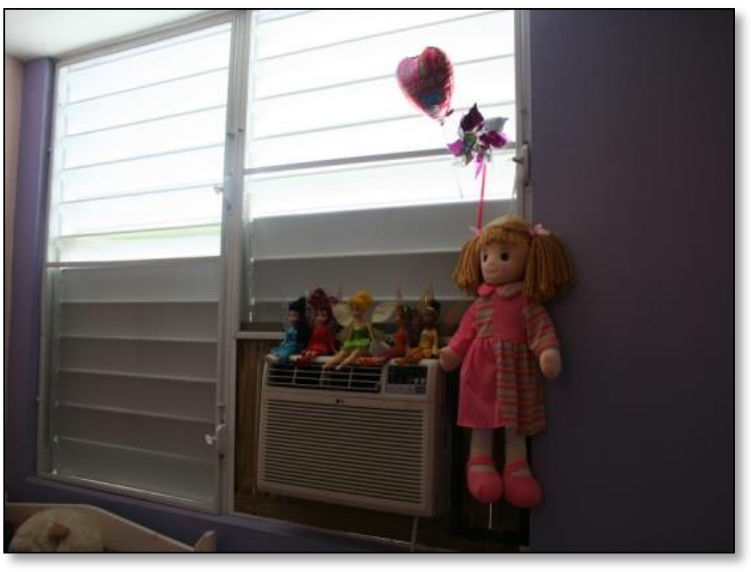

Fig. 2.12. Window A/C Unit

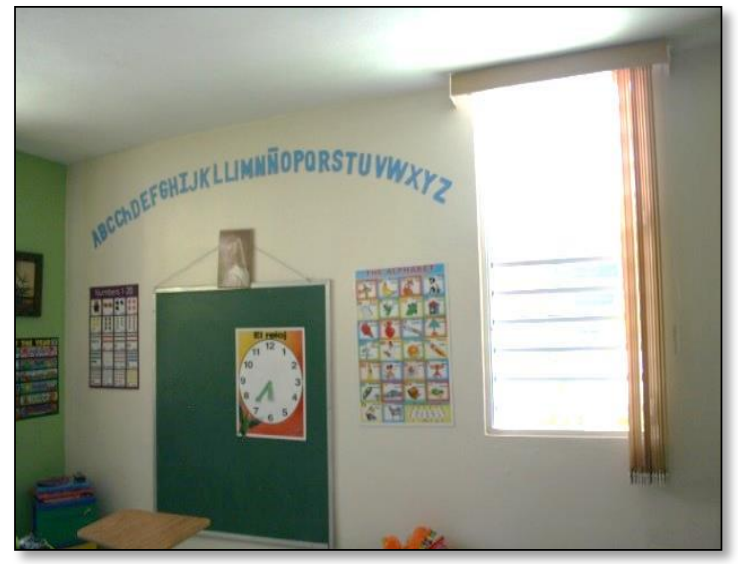

Fig. 2.11. Homeschool room

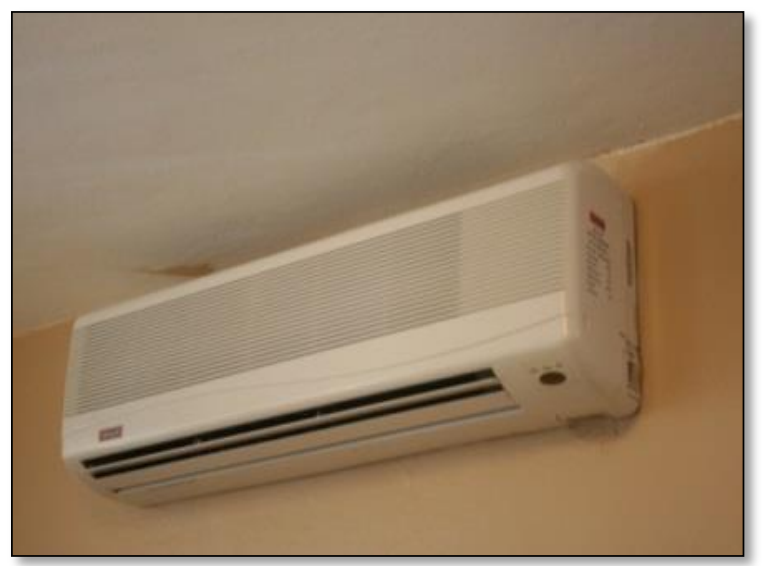

Fig. 2.13. Wall AC Unit

Unit 4: Occupants were a couple with two children. No one is home during the day. Upon arrival for the site visit, the female head of household was just arriving home. The indoor temperature was 87 degrees $\mathrm{F}$. Unit 4 received the following standard WAP measures for Puerto Rico's program: a solar water heater (OG100 Certified), new CFLs, and AC servicing (See Figures 2.14-17). 


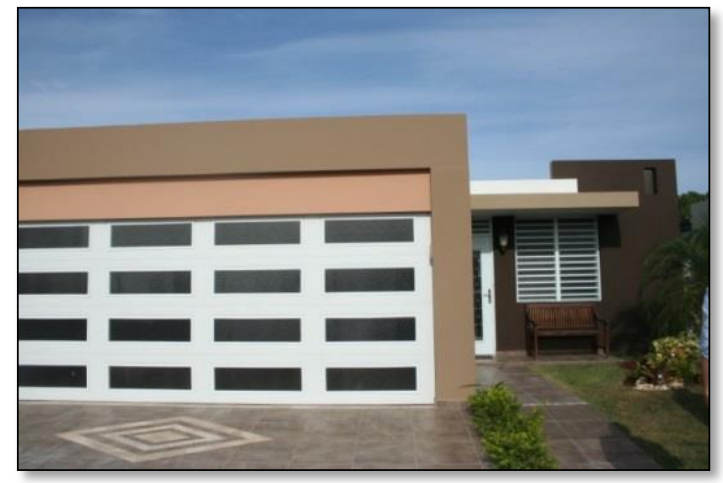

Fig. 2.14. Ponce Region Unit 4

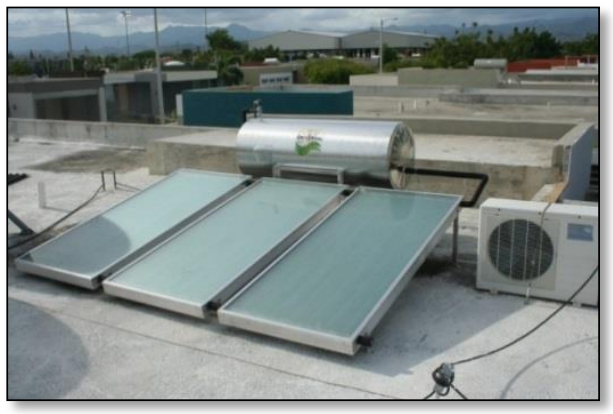

Fig. 2.16. Solar water heaters

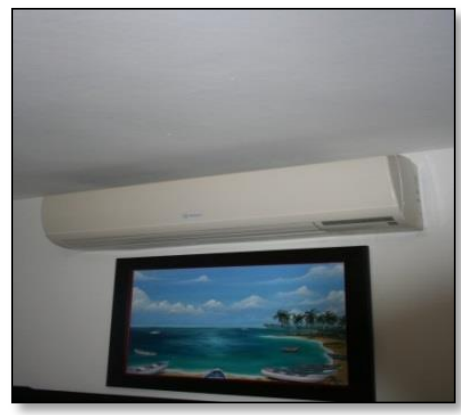

Fig. 2.15. Wall AC unit

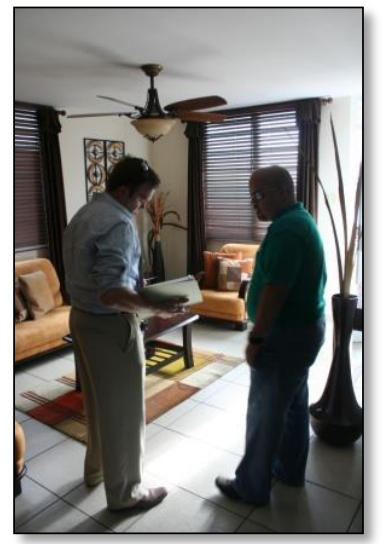

Fig. 2.17. DOE and AFI Program Staff

Unit 5. The occupants of Unit 5 are a mother and child. The home has a mini-split AC with fans on the roof and Miami windows. The family has a propane-fueled washing machine for which fuel is delivered about once every four months. The home has a natural sunlight skylight in the ceiling. Unit 5 received the following standard WAP measures for Puerto Rico's program: a solar water heater, new CFLs, AC servicing and cleaning, and cleaning of refrigerator coils (See Figures 2.18-19). 


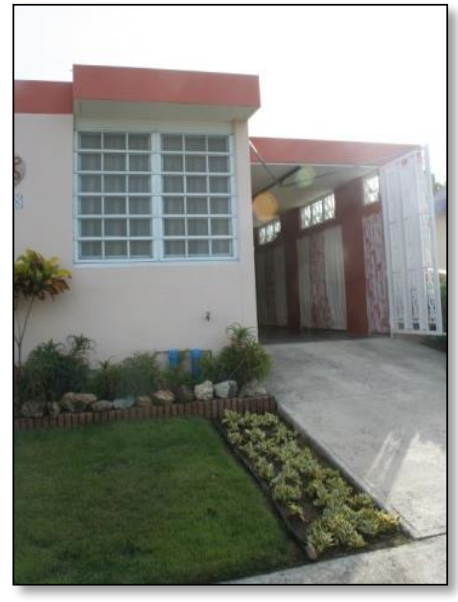

Fig. 2.18. Ponce Region Unit 5

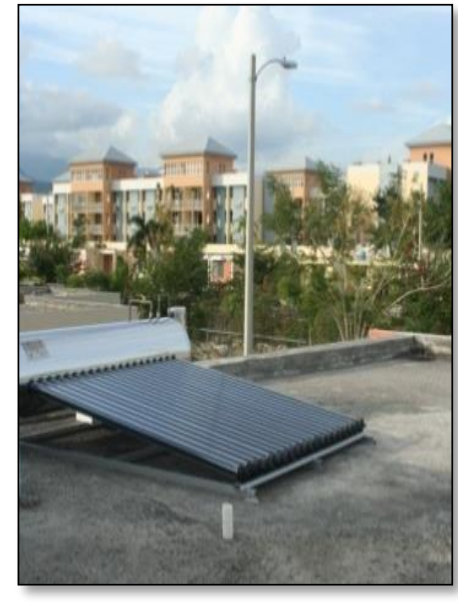

Fig. 2.19. Roof Solar HW Heater

Unit 6. The house is occupied by a family with many children. The family had already installed CFLs prior to weatherization. The AC unit was not working at the time of the audit, so was not replaced. After weatherization, the occupant reported a decrease in her utility bills from $\$ 300$ to $\$ 140$. She reported that her neighbor was not eligible for the program but had installed some of the same measures on his own, based on this household's positive report. Line-drying of clothes was evidenced here even though the family possessed an electric dryer (See Figures 2.20-22).

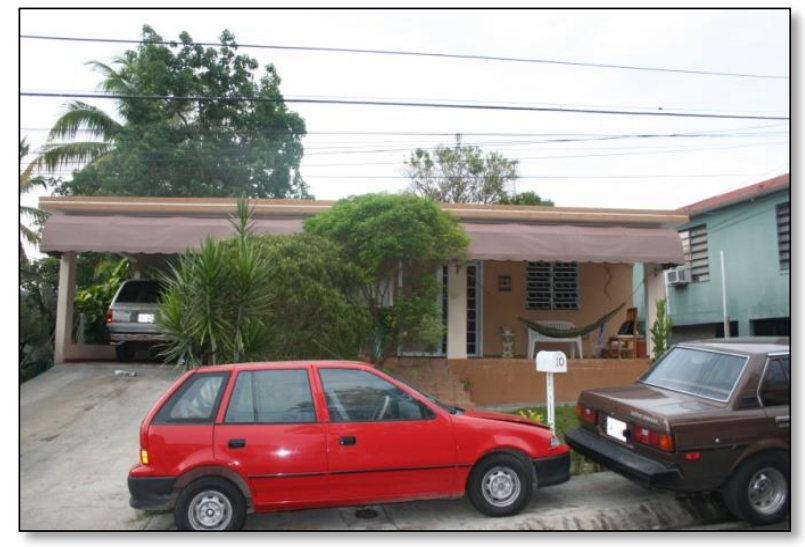

Fig. 2.20. Southwestern Region Unit 6 


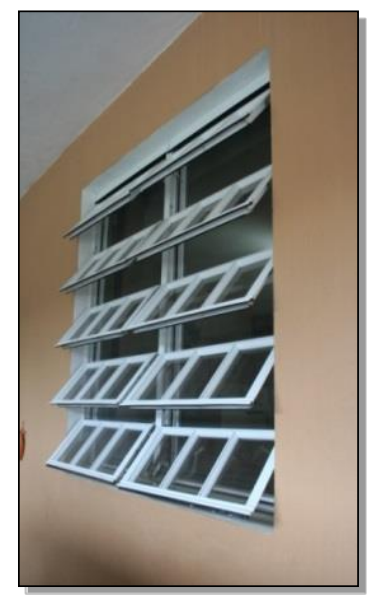

Fig. 2.21. Miami Windows

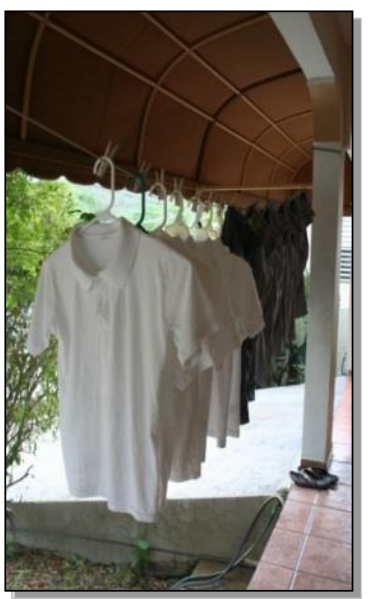

Fig. 2.22. Clothes line-dried

Unit 7. The home is a two-story building with two separate units on each story. Only the bottom unit received weatherization services. After weatherization, the family at first reported no change in their electric bill but then realized the bill was still being estimated rather than metered by the utility company. The electric company did not at first believe the amount of the reduction; they came out a second time for a reading to make sure it was accurate. Unit 7 received the following standard WAP measures for Puerto Rico's program: a solar water heater and a new refrigerator (See Figures 2.23-25).

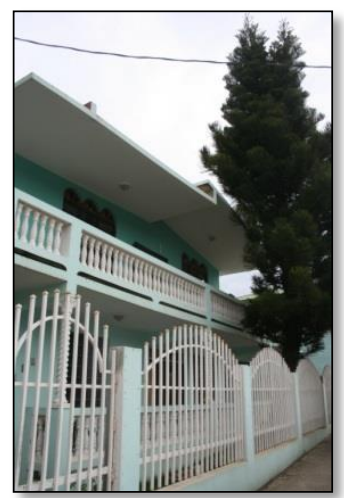

Fig. 2.23. S.W. Region Unit 7

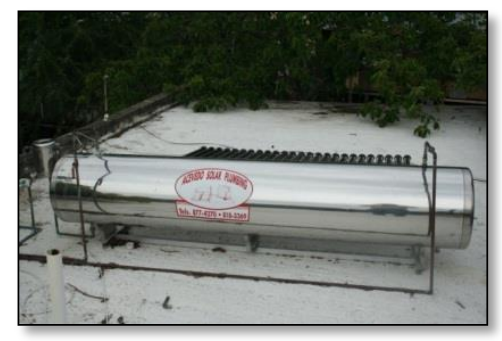

Fig. 2.24. Solar HW Heater

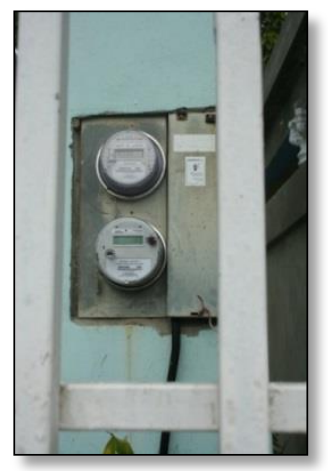

Fig. 2.25. Utility Meter

Unit 8. The home (See Figures 2.26-2.27) is located in a 3-year-old subdivision with solar water heaters on every roof. It has a long patio on the side. The householder reported that the Program had been recommended by friends from work and that her meter was read, not estimated. Unit 8 received the following standard WAP measures for Puerto Rico's program: a new refrigerator and new CFLs. 


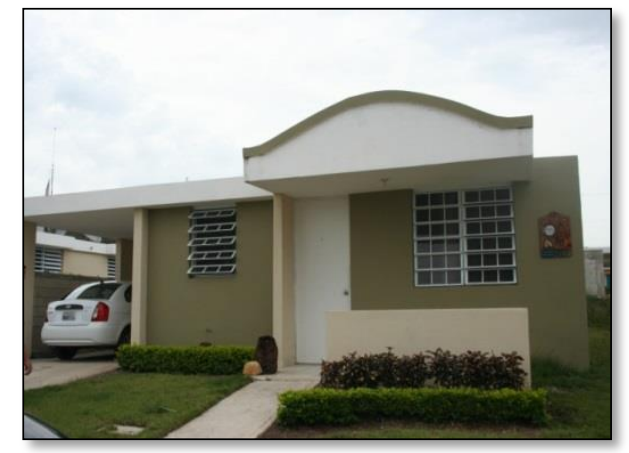

Fig. 2.26. Southwestern Region Unit 8

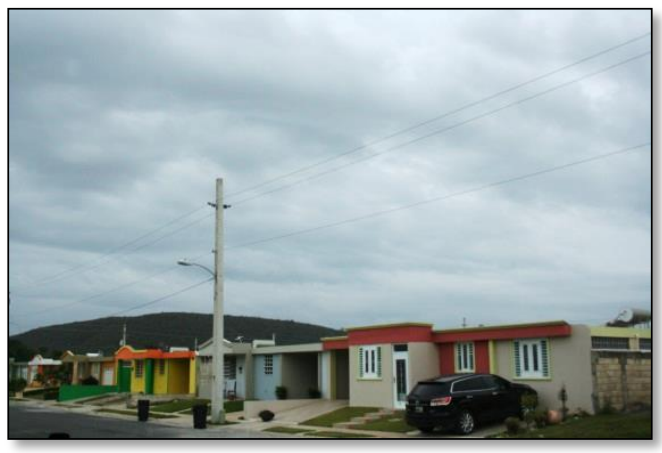

Fig. 2.27. Puerto Rico Housing Development

Unit 9. This home (See Figures 2.28-2.29) did not have AC, so the cooling system was not replaced. However, the female head of household reported having asthma triggered by the pollen outside coming into the home through open windows. Homeowners reported overall satisfaction with the solar water heater and client education, also reporting a decrease in energy bills from $\$ 100$ down to $\$ 64$. The householder reported having replaced the new low-flow showerhead with her old one, which she preferred. Unit 9 received the following standard WAP measures for Puerto Rico's program: a solar water heater, a new refrigerator, new CFLs, and a low-flow showerhead.

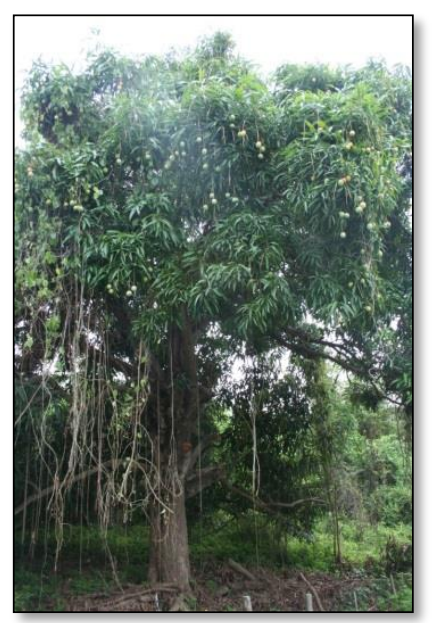

Fig. 2.28. Southwestern Region Unit 9 mango tree

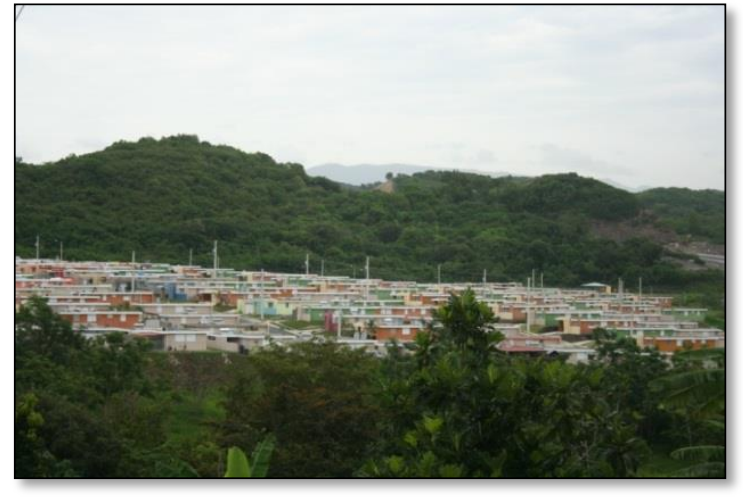

Fig. 2.29. Southwestern housing development with several rooftop solar HW heaters 



\section{HOUSING RESOURCES OF WESTERN COLORADO - GRAND JUNCTION}

\subsection{INTRODUCTION}

Housing Resources of Western Colorado (HR) provides weatherization and other services and programs to seven counties in its area. ${ }^{6}$ Its main office is located in Grand Junction, Mesa County, Colorado, ${ }^{7}$ and a satellite office is located 60 miles away in Montrose County. This non-profit, originally known as the Grand Junction Public Energy Information Office, was founded in 1977. It was awarded its first weatherization contract in 1988. Approximately 56 percent of the agency's weatherization jobs are done in Mesa County, with the rest spread out among the other six counties.

About 40 percent of HR's weatherization jobs are on mobile homes, and most of the remaining weatherization work is on single-family detached homes, but Housing Resources does weatherize multifamily buildings if the units are individually heated.

Housing Resources is widely regarded as a highly efficient and innovative agency; these factors inspired its selection for this report.

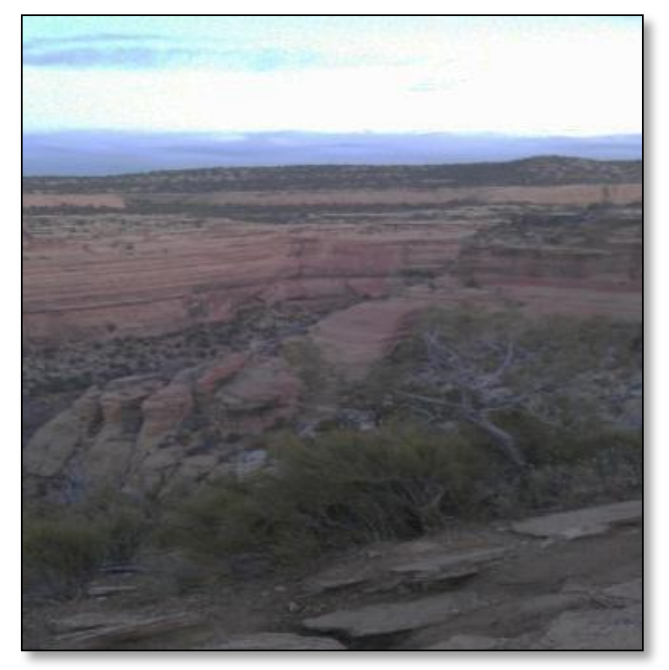

Fig. 3.1. Hot, Dry Climate -

Landscape near Grand Junction, CO

\subsection{PHILOSOPHY AND OPERATIONS}

Housing Resource's guiding philosophy, in theory and in practice, is "people first." Its approach to weatherization is based on making the process as easy and efficient as possible, both for clients' sake and to maximize the funds available for weatherization. The agency takes care to reduce the time and hassle associated with weatherization from the first step: the intake process. For example, if a client is already income-eligible for assistance from the State of Colorado's Low-Income Energy Assistance Program (LEAP), he or she is also pre-qualified for weatherization assistance. Intake for weatherization is accomplished with a simple phone call, and an office visit is not necessary. Confirmation of the

\footnotetext{
${ }_{7}^{6}$ See http://www.housingresourceswc.org/

${ }^{7}$ At 11.6 percent, Mesa County has the second highest rate of poverty within the coverage area; the population is relatively young, with 19.6 percent of the residents under the age of 14. U.S. Census Bureau, 2009
} 
householder's identity is collected when Housing Resources staff members visit the home after intake. In this way, Housing Resources minimizes paperwork and inconvenience, reducing the chances of losing clients and keeping the business sustainable. Non-LEAP recipients, however, must visit a Housing Resources office and bring documentation to support income qualification. The waiting list for weatherization services currently averages about 300 clients, a substantial increase over the pre-ARRA waiting list. It should be noted that HR completed around 200 weatherization jobs per year before ARRA and around 500 per year during the ARRA period.

Housing Resources uses in-house crews, taking care to hire employees dedicated to public service, capable of interacting with a wide range of clients sensitively, and able to handle the physical rigors of home weatherization. Important responsibilities are delegated to crew chiefs and crews, promoting employee engagement and welfare.

Housing Resources' marketing is mostly word-of-mouth, although it gets some business from mailings included in Social Security and pension correspondence. Some statewide marketing efforts with advertisements on radio and TV have also brought in clients.

\section{Intake}

To the extent possible, Housing Resources staff uses the intake process to gather information that will guide each household's weatherization. Prospective clients are asked standard questions about issues such as their housing type, heating fuel(s), allergies, and the type of refrigerator they may have (in case, for example, the crew may be able to bring an appropriate replacement refrigerator with them). Once in the house, Housing Resources gathers additional information. Staff may meter a refrigerator if additional information is needed to determine whether its replacement is cost-efficient.

Housing Resources merges the audit and initial weatherization processes. Typically, the agency sends a three-person crew in a fully stocked and outfitted 16' truck (See Figure 3.2) to most jobs. After a modest amount of paperwork is completed with the client, the crew chief conducts an audit using a priority list (pre-ARRA), determines what needs to be done in the home, and then with the approval of the client, immediately puts the crew to work. The same process is followed today with the exception of the added computer-aided audit system.

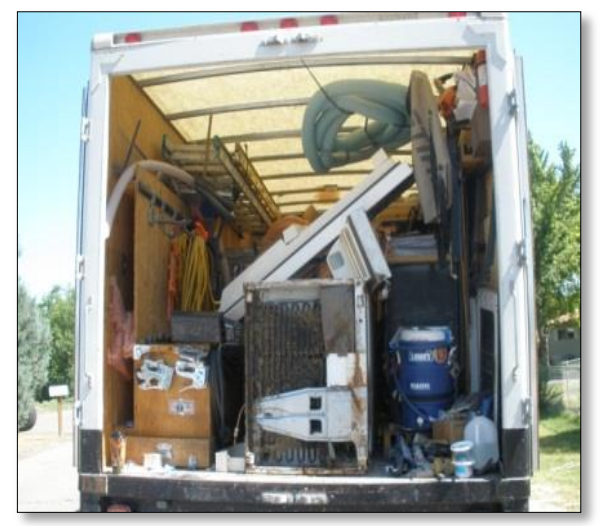

Fig. 3.2. Fully equipped crew truck 
The crews are responsible for all aspects of weatherization, such as blowing insulation and installing storm windows, and are given substantial decision authority at the site. The crew can bring a new refrigerator, install it, and haul out the old one. Two crews specialize in furnace replacement, typically installing 95\% energy-efficient condensing furnaces for $\$ 1100-\$ 1200$, one-third to one-fourth of the price a private contractor would charge. Crews install about 200 furnaces in homes a year, amounting to 34 percent of their weatherization projects.

Housing Resources has its own glass shop and storage sheds (See Figure 3.3). Normally, a crew arrives at a house with everything it needs, including insulation, windows, appliances, and tools. If needed, storm and replacement windows are built in the shop, quickly and inexpensively. The crew picks up new

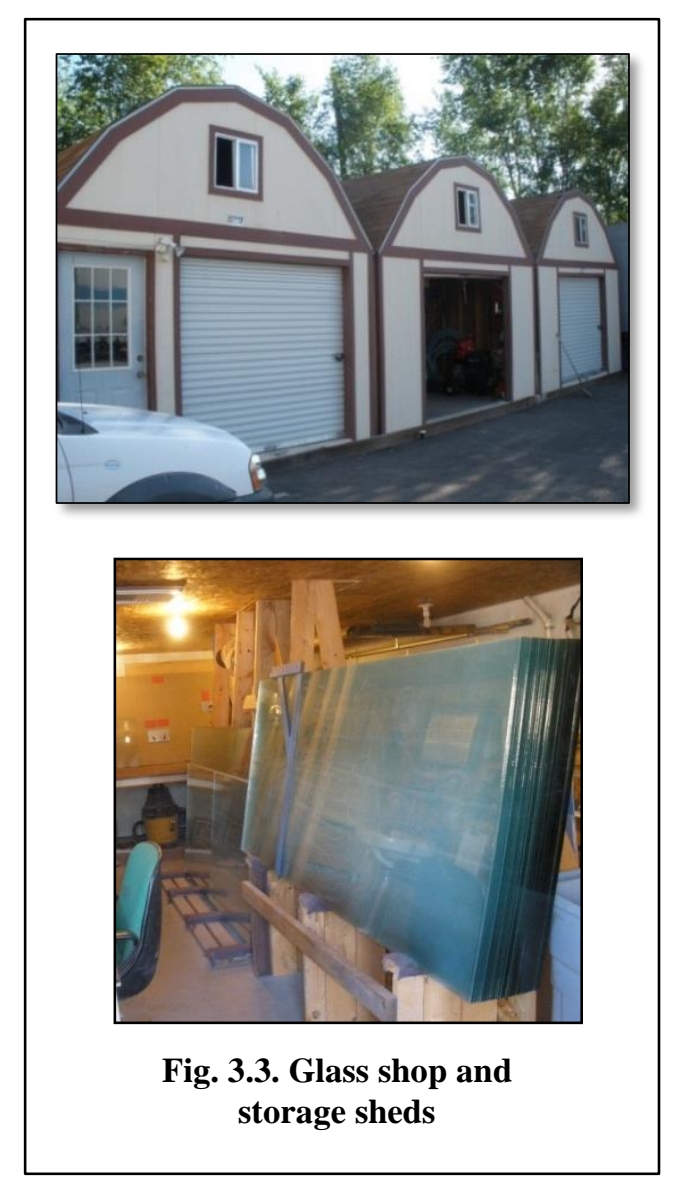

refrigerators and furnaces from local retailers en route to the homes. The inspector is called a couple of hours before the job ends and corrections are made while the crew is still there. Most jobs last one to five consecutive days. By combining the audit and weatherization processes and by relying on in-house crews, except for electrical wiring, HR saves time and money.

"Rather than saying what we are going to do and then the next time doing it, we just do it," according to the weatherization director. This greatly increases efficiency as well as minimizes the number of times the client needs to be home. 


\section{Deferrals and Walk-aways}

Deferrals generally occur only when roof or structural damage is present, and in those cases work is only deferred until repairs are made. Housing Resources is able to leverage other services in this situation by drawing on resources from its Housing Rehabilitation program. In this program, a loan is required and is dependent on the amount of equity the homeowner has in the house. This process can cause some delays while approvals are pending. However, weatherization funds may be applied if the repairs are costeffective, such as fixing a simple roof leak. Otherwise, the landlord or owner must assume financial responsibility for those structural repairs before weatherization services can begin.

"Walk-aways" may occur when weatherization work cannot be performed because there is a health-andsafety concern related to excessive clutter, or when cleanliness or hostile clients are an issue. However, these situations have been rare.

\section{Client Education}

Client education is part of the job description for weatherization crews. In addition to giving informative brochures to clients, the crews routinely answer questions as they work, making a point of explaining their work to clients and offering energy-saving tips as appropriate. For example, they may talk about the costs of running an extra refrigerator or freezer, or they may advise clients to close vents and doors to unused rooms and to turn down heat at night and when out of the home. Approximately 60 percent of the clients are estimated to be receptive to such information.

\section{Leveraging}

In cases where a house needs repair that cannot be addressed under WAP, and the repair is beyond the Housing Rehab program's capabilities, Housing Resources also searches for funds from other sources, such as Housing and Urban Development (HUD) or Mesa County, or non-profits like local churches. If the damage to the house is a health-and-safety concern, then the repairs need not be run through the costeffective guidelines and WAP funds can be used. Housing Resources investigates how each individual case can be managed to take advantage of available programs in order to avoid a walk-away.

Beyond these limited cases, however, Housing Resources does not have access to a significant amount of leveraged resources. For example, they do not receive any re-directed LIHEAP funds from the State of Colorado. Utility funds are available in some areas, in the form of rebates for specific weatherization measures. These funds complement weatherization activities and can be used to enable some measures to meet the SIR test by reducing the cost.

\subsection{INNOVATIONS}

Housing Resources takes pride in its innovativeness. One such innovation is perimeter insulation, using the "belly burrito" (See Figure 3.4). Developed by field crews in Grand Junction, the belly burrito is an improved technique for insulating the bottoms of mobile homes. The conventional approach to weatherizing the bottom area of a mobile home is to blow fiberglass insulation into the belly cavity of the unit. This approach can result in damaged caused by leaky pipes that produce ice during the winter season even after weatherization had been completed. In homes with typical blown belly insulation, ice under the floor can be a major energy and comfort problem. In addition, plumbing repairs often require cutting open the belly and removing the blown-in insulation. Voiding the belly below the plumbing leaks does not seem to work well, as water is wicked into the surrounding insulation, saturating it with water. The "burrito" is a long batt of fiberglass insulation wrapped with vapor-guard plastic and applied around the inside perimeter of the skirting under the mobile home. Many crews install more easily managed 25' 
sections. For installation, either the skirting is removed or the insulation must be folded to fit through the access. The batt is then placed adjacent to and attached to the perimeter framing under the mobile home (See Figures 3.5 and 3.6).

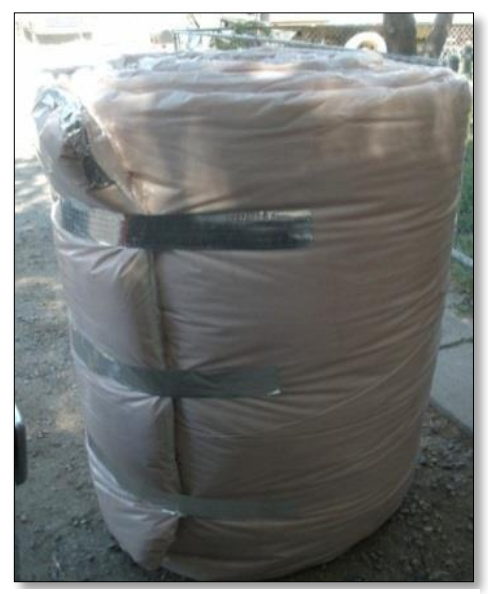

Fig. 3.4. "Belly burrito" Insulation Roll

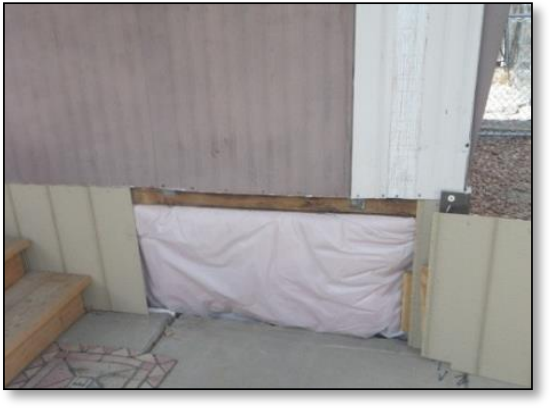

Fig. 3.5 Burrito insulation viewed from side of mobile home.

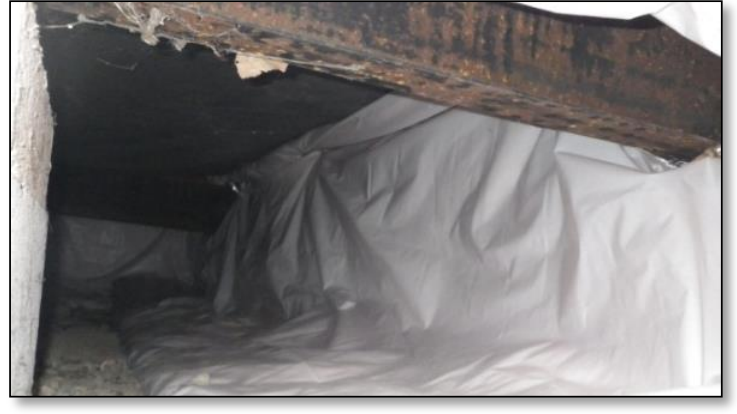

Fig. 3.6 Insulation viewed from underneath the mobile home.

Before this innovation, the average unit expenditure was less than $\$ 3000$ per home, and belly insulation was the most expensive weatherization component installed. The budget could not normally accommodate both belly insulation and a furnace replacement. Large-scale evaluation results in Colorado and in other states, where belly insulation energy savings were not as great as anticipated, indicated that the use of belly blown insulation might not be either cost-effective or durable. State monitors had found flooded belly cavities where plumbing leaks had damaged insulation after the weatherization process had been completed and older jobs where belly patches and insulation had been removed. Due to these issues Housing Resources was requested to pilot an alternative technique to the traditional method. The cost for the belly burrito was found to be about half that of blown insulation referred to as the "belly blow." Clients whose houses received belly burrito insulation stated that their floor is much warmer and that the pipes don't freeze any more. Billing analysis over the following year confirmed energy savings that were comparable to savings for blown-in belly insulation. Other agencies quickly adopted the measure and installers overwhelmingly approved. Therefore the belly burrito technique was included, with a conservative energy savings estimate, in the Colorado state weatherization plan. Agencies outside the state of Colorado are expressing interest in trying the method as well; however there are climate considerations and this technique may not work well in wet climates. 
Other cost-effective methods have been pioneered by this agency as well. Housing Resources employs a novel technique to weatherize window openings, installing less expensive built-in-house storm windows rather than buying expensive replacement windows. By installing a pin-on storm window panel on the inside of the operable window sash and another on the outside of the fixed window sash, Housing Resources saves the time and expense by preserving the existing window (See Figure 3.7).

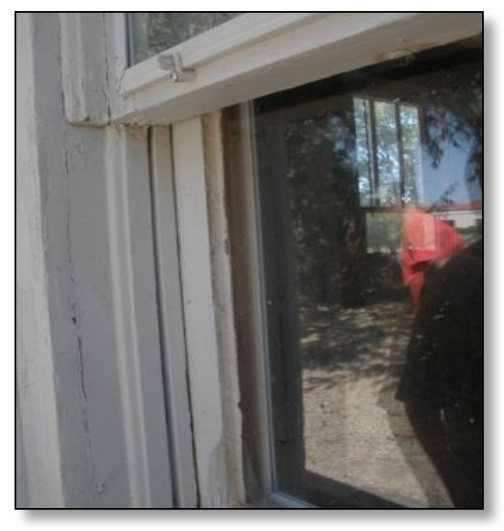

Fig. 3.7. Double-storm window innovation.

These "double-storms" can be fabricated for around $\$ 10$ in-house, depending on the size of the window. For large windows, an "H-channel" can be constructed to split the window in half so storm windows can be built; this still leaves one side able to slide open. Installing storm windows instead of replacing existing windows also reduces the need for Housing Resources' crews to deal with potential lead contamination around the window.

In another cost-effective innovation, Housing Resources uses insulation produced from recycled local newspapers. Every year, a Salt Lake City company picks up old newspapers from Grand Junction and loads them into a tractor trailer; the newspapers are recycled into cellulosic insulation in Salt Lake City before being reloaded into the tractor-trailer as 700 or so bales of insulation--between 20 and 30 tractor-trailers full (See Figure 3.8). These are then delivered on-site to Housing Resources before the tractor-trailer is put back on the road to collect more newspapers. The system reduces the amount of newspapers being dumped into Grand Junction's landfills, saves energy in the production of Housing Resource's insulation, and reduces purchasing costs.

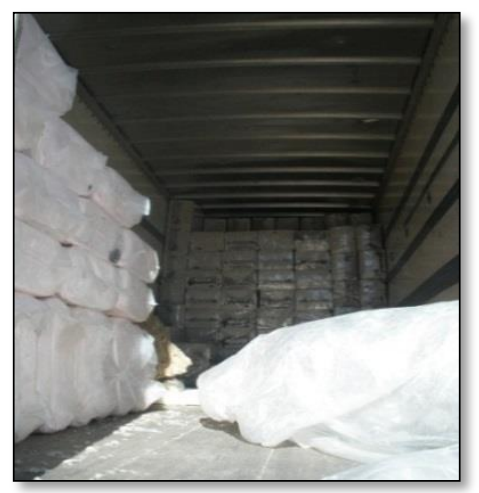

Fig. 3.8. Locally generated cellulosic insulation. 


\subsection{ARRA PERIOD}

The ARRA period challenged Housing Resources in many ways, as both demand and productivity doubled. The agency increased production from about 200 weatherized homes per year to over 500 by increasing staff (installation crews have doubled from three to six), and fielding two furnace crews instead of one. Additional vehicles, blower doors, etc., have been added. More weatherization measures are being installed in homes, but the average weatherization costs per home are running substantially below the ARRA-period \$6,500 threshold, and, as expected, the SIRs for the added measures are lower than those typically installed pre-ARRA.

\section{Davis-Bacon Act}

As for most agencies, the Davis-Bacon provision in ARRA has been a hindrance to HR's smooth operations. In their words, " $70 \%$ of the inconvenience is the weekly payroll reporting." Several potential business partners have declined to become involved in Housing Resources' activities because of DavisBacon reporting requirements. It has been especially inconvenient on the rare occasions when a specialized contractor partner does only one job for Housing Resources and Davis-Bacon required that Housing Resource do weekly payroll reporting for the rest of the year. However, other than delaying the expenditure of ARRA funds, the Davis-Bacon prevailing wage requirement has not been an issue for Housing Resources because the wages paid to their contract employees already exceed the prevailing wages determined by the Department of Labor for weatherization jobs.

\subsection{COLLABORATIONS AND LOCAL INNOVATIONS}

While Housing Resources offers other services in addition to weatherization, including housing rehabilitation and home rental assistance, a fourth program, Self-Help, uses volunteer labor to build new homes somewhat in the model of Habitat for Humanity. However, the Self-Help program differs from Habitat for Humanity's in that Housing Resources buys a large parcel of land that is subdivided into housing plots. The prospective owners of the new homes work together to build all of their homes simultaneously. No one can move in until all the homes are completed. Prospective home-owners may work over 30 hours a week for as much as six months to complete the subdivision. In addition to encouraging homeowners to contribute "sweat equity" and build a sense of community, Self-Help program workers gain valuable and marketable experience; exemplary workers have been hired into Housing Resources' weatherization program (See Exhibit 3.2).

Housing Resources has been a pioneer institutionally as well as technically, being the first to work with the LEAP to promote the weatherization program and setting up a model program for the state of Colorado in working with and hiring youth from the local youth corps. Housing Resources received a state funded grant to provide refrigerators, furnace replacements and low cost-weatherization measures in previously weatherized homes where these replacements had not been completed the first time around. When the budget crisis hit, the state asked for the return of this funding. However, Housing Resources thought of using the Youth Conservation Corps in the WAP at the time the Youth Corps was delivering and installing CFL light bulbs and low-flow showerheads for non-WAP clients. A representative from Housing Resources talked with the local youth corps and proposed that instead of giving money back to the state, that they allow Housing Resources to donate the money to the local youth corps to do more than they were already doing. Since they were already at the house, the young people could also install swamp cooler covers, set-back thermostats, clotheslines for solar clothes drying, adjust fridge temperatures, clean refrigerator coils, and perform mini-audits to capture necessary information. The young people were able to identify furnaces and fridges that needed replacement, document model numbers, collect signatures and the information that was required for appliance delivery. The plan worked so well that the state used this 
model in their next grant cycle. Some of these young people ultimately became weatherization employees for Housing Resources.

\subsection{EXHIBITS}

\subsection{Exemplary Weatherization Job}

Housing Resources gives substantial responsibilities to crew leaders, allowing crews a good deal of flexibility in dealing with unusual situations. For example, Housing Resources was contacted by a retired woman who had recently moved to Grand Junction and lived in a 100-year-old ranch home in Grand Junction. The client's heating bills were quite high, yet the home was still cold. She had heard about Housing Resources' by word-of-mouth and had requested weatherization services.

The weatherization crew found an old, inefficient and potentially unsafe heating system in the home. The old furnace was located under the floor between the living and dining rooms (See Figure 3.9) and was visible through a grate. When the furnace was in operation, the client could see its flames through the grate. The grate was the only heat vent into the house, which left the bedrooms and other outer rooms virtually unheated, but the grate itself was too hot to touch when the furnace was on, even her cats had learned not to step on the grate.

The crew chief proposed and received permission to solve this dangerous and inefficient heating problem by installing a new furnace (See Figure 3.10) and constructing a new heating delivery duct system. The crew cut holes in all the rooms of the house for the new heat registers and then designed and built the duct system in a very tight crawlspace. The crew also installed a set-back thermostat, which the crew chief set for the client; installed a cover on the evaporative "swamp" cooler; installed storm windows; and blew in wall and attic insulation. The entire cost for this job was less than $\$ 6,500$ and the client was extremely pleased.

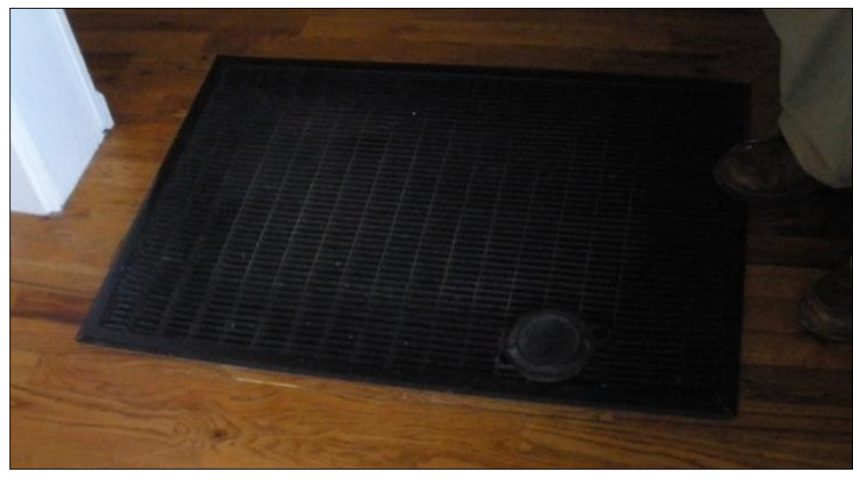

Fig. 3.9. (Pre-weatherization) Grate for sole heat source in residence. Open flames were visible from above.

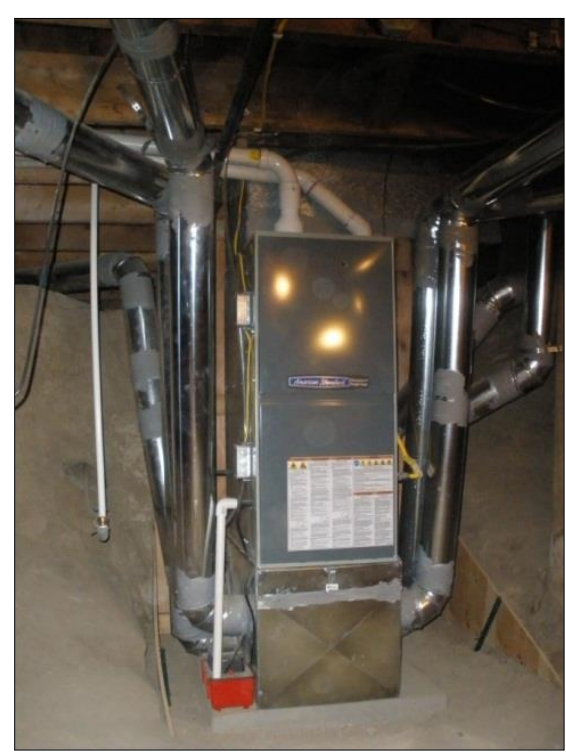

Fig. 3.10. New energy-efficient furnace installed in crawl space with new duct work. 


\subsection{A Self-Help Success Story}

One of the most popular programs offered by Housing Resources of Western Colorado is its Self-Help Program. Self-Help purchases land for subdivisions and then contracts with volunteers to build homes within the divisions. In return, the volunteers can become home owners. A unique aspect of this program is that all volunteers work on all the homes in the subdivision, and no one is allowed to move in until all the homes are finished. Although this program is unrelated to the WAP program, an ambitious volunteer, Frank Moreno for the Self-Help Program, was recruited as a crew leader for the WAP program

(Fig. 3.11).

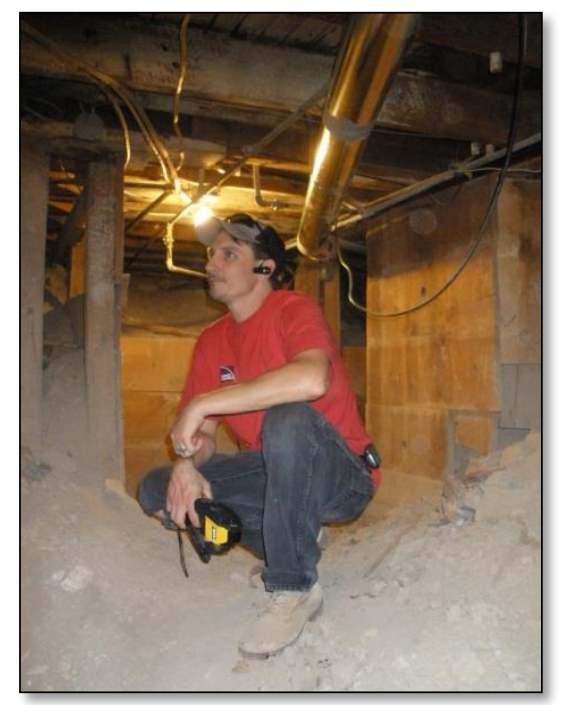

Fig. 3.11. Frank Moreno, Inspector/ Project Coordinator

Frank Moreno of Grand Junction initially saw the Self-Help program as a good way for him and his pregnant wife to become homeowners. Moreno spent more than 30 hours per week over a nine-month period on this endeavor. Developing new skills, he became a volunteer crew leader. After much hard work and patience, he and his family now live in a new Self-Help home in a 30-home subdivision.

Noting the quality of Moreno's work, Housing Resources offered him a job in its weatherization program, where he has worked his way up to become one of Housing Resources' weatherization job inspectors, also helping to coordinate crews and client schedules. Like many Housing Resources crew members, he regularly checks on several elderly clients to make sure their thermostats are set and their evaporative "swamp" cooler covers are either on or off, depending on the season. 



\section{COMMUNITY ACTION PARTNERSHIP - LEWISTON, IDAHO}

\subsection{INTRODUCTION}

Lewiston, Idaho is a small community of a little over 30,000, located at the confluence of the Clearwater and Snake Rivers in western Idaho. Its sister city, Clarkston, lies just across the Snake River in Washington State. A plateau rises from the river valley along Lewiston's eastern border, allowing a breathtaking view of Lewiston (See Figure 4.1).

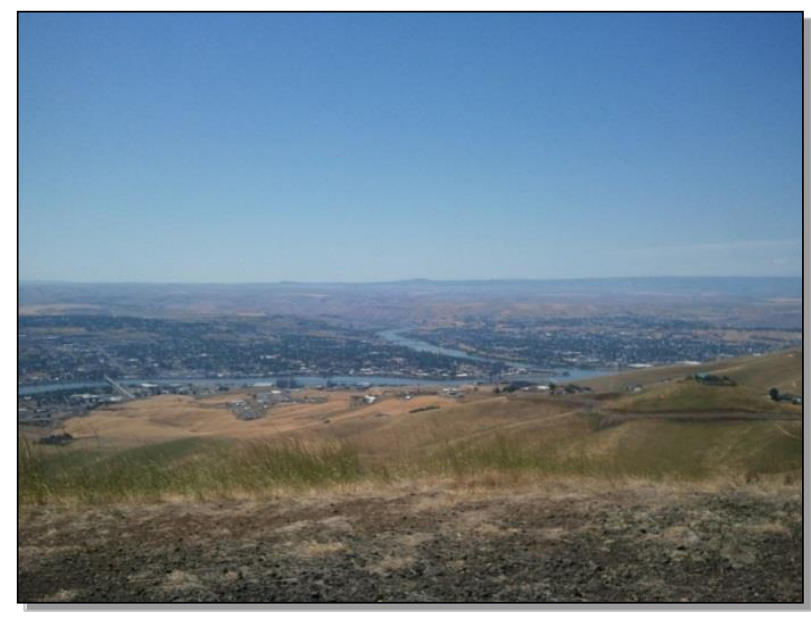

Fig. 4.1. Lewiston, Idaho

The Community Action Partnership (CAP) of Lewiston serves the 10 northernmost counties in Idaho, also providing weatherization services to Asotin County, Washington, on the southeastern flank of that state and far from other weatherization agencies. The Program's service area runs more than 300 miles north to the Canadian border and 100 miles south from Lewiston.

The Lewiston CAP, like many others, was founded during the 1960s when legislation passed by the Johnson Administration established the agencies across the country and funded them through community block grants. The Lewiston CAP offers a wide range of programs to its communities, serving as an Area Agency on Aging, and providing child-care resources and referrals on housing, weatherization, energy assistance, telephone assistance, nutrition, and general community needs. The Idaho weatherization program was started in 1984.

\subsection{PHILOSOPHY AND APPROACH}

The CAP's motivating philosophy has two components. At the strategic level, the Lewiston CAP's primary focus is on the health and safety of its clients and is succinctly expressed by its mission statement, which appears on the back of the CAP trucks (See Figure 4.2). The mission statement's goals, in practice, are "Overall client needs come first, followed by a focus on energy savings."

At the implementation level, the philosophy is simple: to get the job done without complaints. As a result, the weatherization program is run very efficiently by a veteran staff who takes pride in their jobs and in helping households in need. Although the Lewiston CAP is a non-profit, it is run like a private-sector business, continually working to keep both federal and leveraged funds for weatherization in the pipeline. This program is also administratively thrifty, keeping its overhead costs for program operations around 35 
percent of total costs and spending most of its money on the installation of weatherization measures. One result of this two-pronged philosophy (addressing client needs and excellent service) is that this weatherization program rarely if ever has to "walk-away" from a home. If an auditor encounters a difficult client, this CAP brings in a social worker to work with the client and ensure that the weatherization process moves smoothly. The CAP also has the capability to work with disabled and hearing-impaired clients. Other resources are regularly tapped to repair roofs and deal with various issues in the home, prior to weatherization.

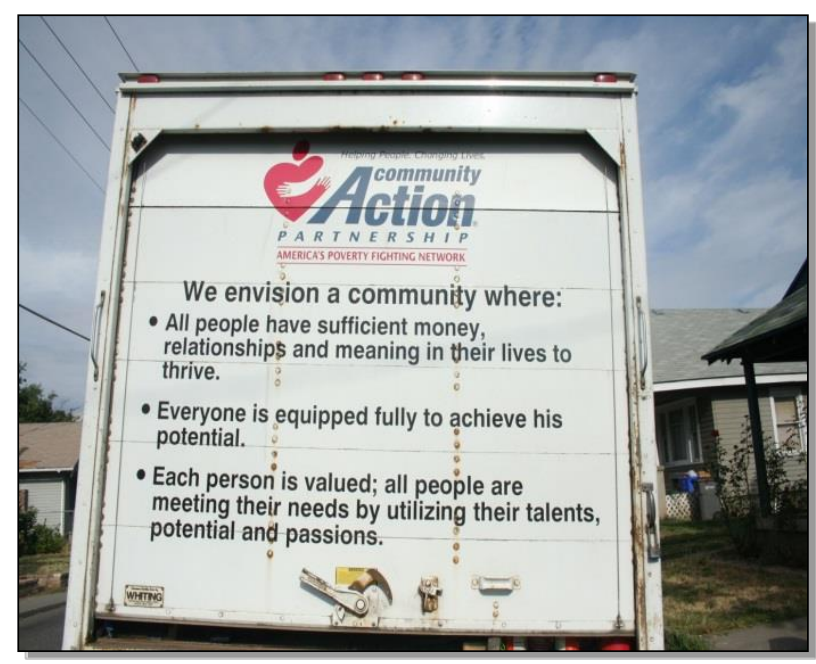

Fig. 4.2. Lewiston Community Action Partnership Mission Statement

\section{Crews, Materials and Implementation}

Like many local weatherization programs around the country, the Lewiston WAP agency is primarily crew-based, but it hires specialized contractors when necessary-to replace furnaces, for example. As noted above, the weatherization program's staff is very experienced, so the program manager trusts the crew to work with a certain degree of independence (See Figure 4.3 and 4.4).

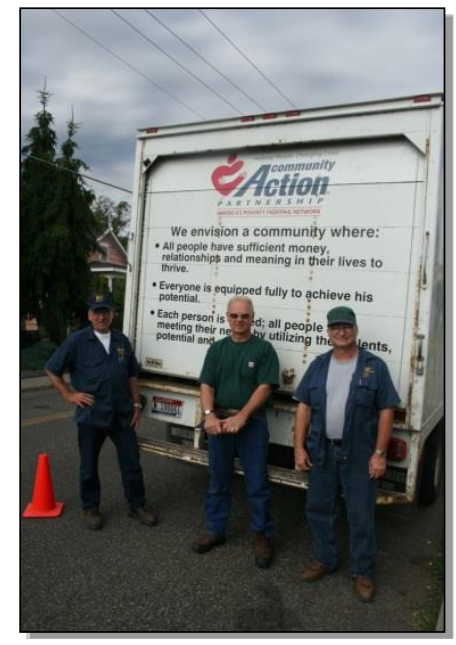

Fig. 4.3. Lewiston CAP Crew Chiefs and Program Director

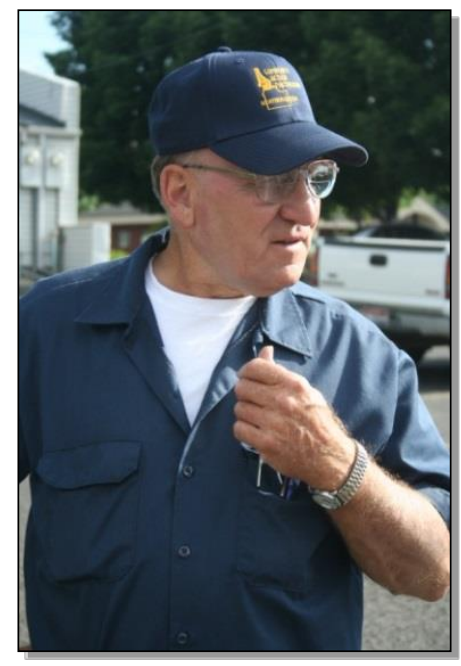

Fig. 4.4. Program Director, Larry Stamper 
Crew chiefs are given responsibility and authority to adjust jobs when conditions that were unnoticed during the audit phase are discovered. This on-site flexibility is a major advantage of the in-house crew model for this agency.

Because the service territory is so large, crews are typically rotated weekly to work either on jobs in or near Lewiston or on jobs away from Lewiston that require overnight stays in hotels. The program experimented with moving to four ten-hour days per week to reduce "away" time, but after careful review, it was decided that the traditional five eight-hour days per week led to higher production rates and quality, so the schedule reverted.

The weatherization program uses the EA5 computer auditing tool, which is provided by the state of Idaho. Once the audit has been completed, the customized set of allowable measures, from insulation to air sealing, is installed. Furnace replacements are installed in about 15 to 20 percent of homes. All jobs are inspected post-weatherization, and clients are asked to sign off that work has been done to their satisfaction.

The weatherization program keeps a large, clean, and well-ordered materials warehouse in Lewiston (See Figure 4.5). A routine and comprehensive process is followed for checking materials out to crews for loading onto their trucks at the beginning of the week, and, at the end, checking materials back in when the crews return to the warehouse.

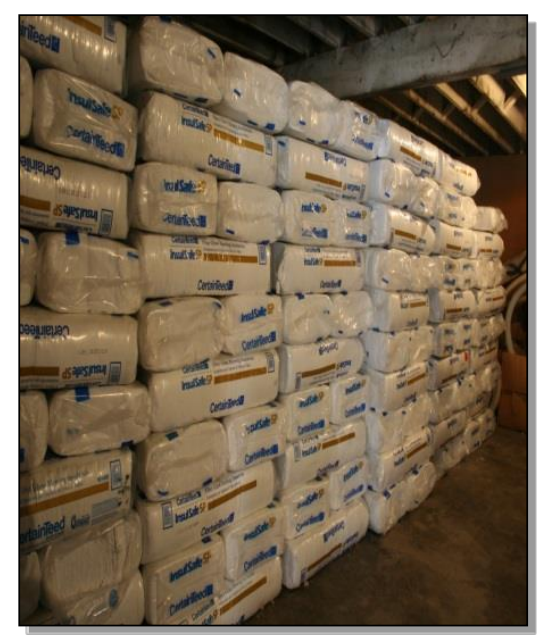

Fig. 4.5. The Lewiston CAP warehouse

The weatherization program has evolved considerably since the 1980s. It has increased annual staff training. It also employs more diagnostic tools. For example, blower doors and duct blasters are routinely used as part of the auditing process.

\section{Impact}

Most WAP clients are referred to weatherization through the CAP's energy assistance program, which provides energy help to over 30,000 households in its ten-county service area. Recipients must qualify annually, and almost 60 percent of the households are headed by females. The service territory contains few minorities, non-tribal reservation households. The weatherization program's portfolio is about 60 percent mobile homes and 40 percent single-family houses; only a few small multifamily dwellings with 
individually heated units are weatherized by the Program. Most homes are heated with electricity or natural gas, and rarely with bulk fuels such as propane.

The Lewiston weatherization program typically has a long waiting list. According to Federal guidance, designated priority households are placed higher on the waiting list than non-priority households, but at times, the list is so long that the CAP can only deliver prompt service in homes experiencing emergency situations, such as a broken furnace in winter. The weatherization program re-assesses applications that have been on the waiting list for more than a year.

\section{Combustion and Radon Safety}

Natural gas is commonly used in the Lewiston area for heating and cooking. This program emphasizes combustion testing and safety. While the crews do not test for radon, 6-millimeter plastic vapor barriers, as required by state law, are regularly installed. Even very narrow or confined crawlspaces receive these vapor barriers, as well as insulation (See Figure 4.6).

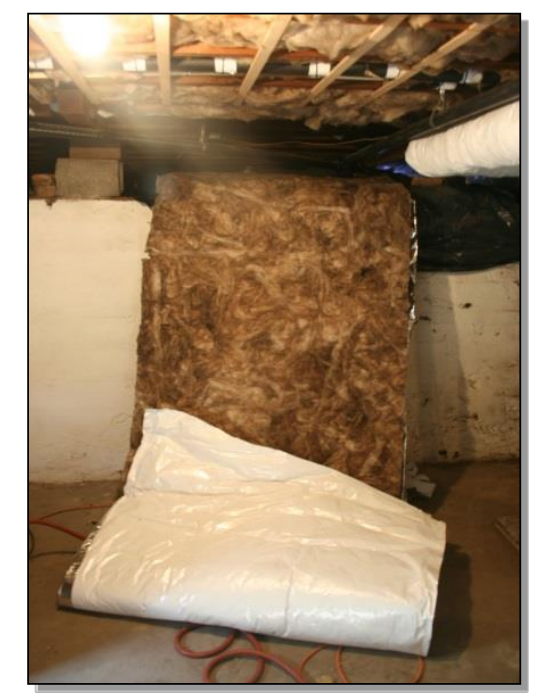

Fig. 4.6. Crawl space

\section{Lead-safe weatherization}

Homes built before 1978 are assumed to have issues with lead contamination; all crews are trained in lead-safe weatherization (LSW). The case study team witnessed LSW on a small 80-year-old home in Lewiston. Figure 4.7 and 4.8 shows the fully protected lead abatement crew replacing old windows on a home. Figure 4.9 shows how crew protects a healthy stand of garden corn from lead dust contamination as the windows are replaced. 


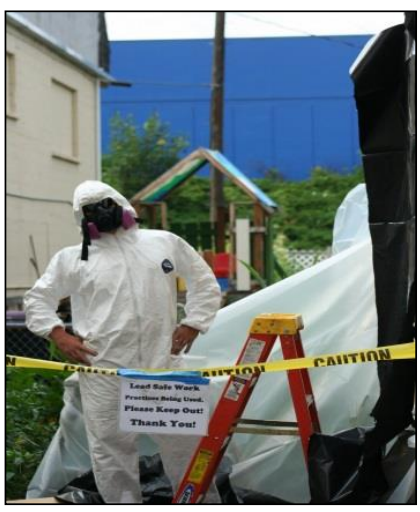

Fig. 4.7. Enforcing LSW practice

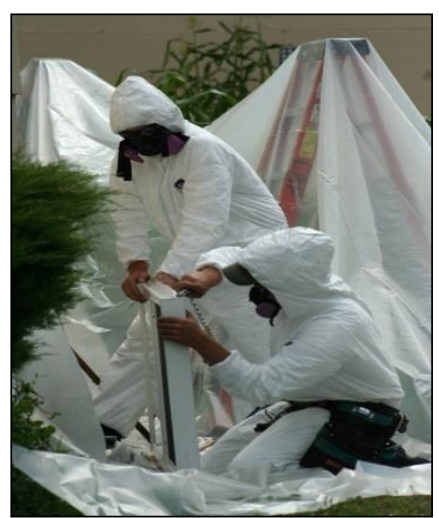

Fig. 4.8. Window replacement crew in full lead protection kit

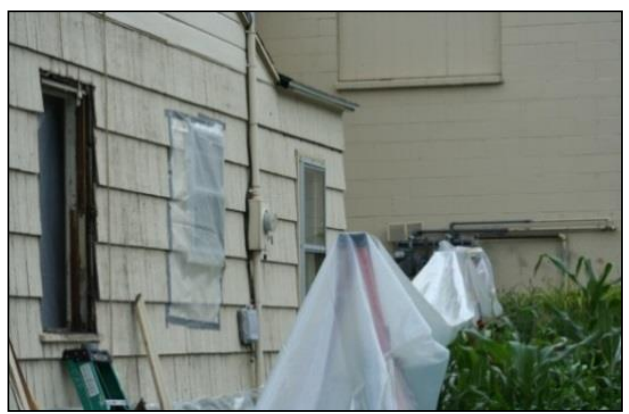

Fig. 4.9. Lead-Safe window replacement with plastic garden barrier

\section{Client Education}

\section{Profile 4.1: Full-Time Home Energy Educator}

In past years, the Lewiston weatherization program employed a common process to client education. Auditors spent some time discussing the weatherization process with clients and provided educational materials. Crew chiefs, crews, and inspectors answered clients' questions during the weatherization process. However, it was judged that insufficient time was given to really educating clients about all aspects of energy use in their homes. As a response, the Lewiston weatherization program now has a staff member whose sole responsibility is energy education. This position is supported mostly from Avista Utilities funds. The current energy educator, Maria Lacey, accompanies auditors to homes as often as possible, and educates the clients while the auditors do their work. She directly interacts with clients between 30 minutes and four hours, depending on the length of the audit process and how open they are to discussion.

Lacey first explains the audit process, including why a blower door test is being done and the types of health and safety issues the auditor is concerned about. Most clients have a pretty good idea of what is going to happen, but some clients, especially the elderly, are not very familiar with the issues or the procedure; in addition, they may be reluctant to accept help from the government. In such situations, Lacey explains that the source of the funding for the program is taxpayers and that they had been taxpayers for many, many years. They are simply receiving a return on the taxes they have paid.

Lacey's favorite teaching tool is an energy meter (See Figure 4.10). She plugs it into a wall socket. Then she screws in a conventional incandescent light. After a few minutes, the meter will estimate annual energy costs for keeping this particular bulb lit. Then she replaces this bulb with a CFL. The meter then estimates weekly, monthly and annual energy costs for this bulb, which of course are a lot lower. Because many clients have misgivings about CFLs, she has a third bulb, a clear halogen bulb with a visible filament, which she screws in to show that there are even more alternatives. For those clients concerned about mercury in the CFLs, she makes a dot with a pen on the bulb to indicate how much mercury is actually in a CFL (not much but they still need proper disposal). She will leave light bulbs with the clients for the crews to eventually install.

Lacey uses a binder that she has prepared to show clients, one page at a time, to educate them on energy efficiency (See Figure 4.11). She is careful to discuss the issue of phantom loads and highly recommends power strips to homeowners. If she can spend more than an hour in the home, she will move on to other topics, such as aeration, showerheads, and programmable thermostats. Lacey finds that most homes have 
Energy Star consumer electronics, but far fewer have large Energy Star appliances such as washing machines.
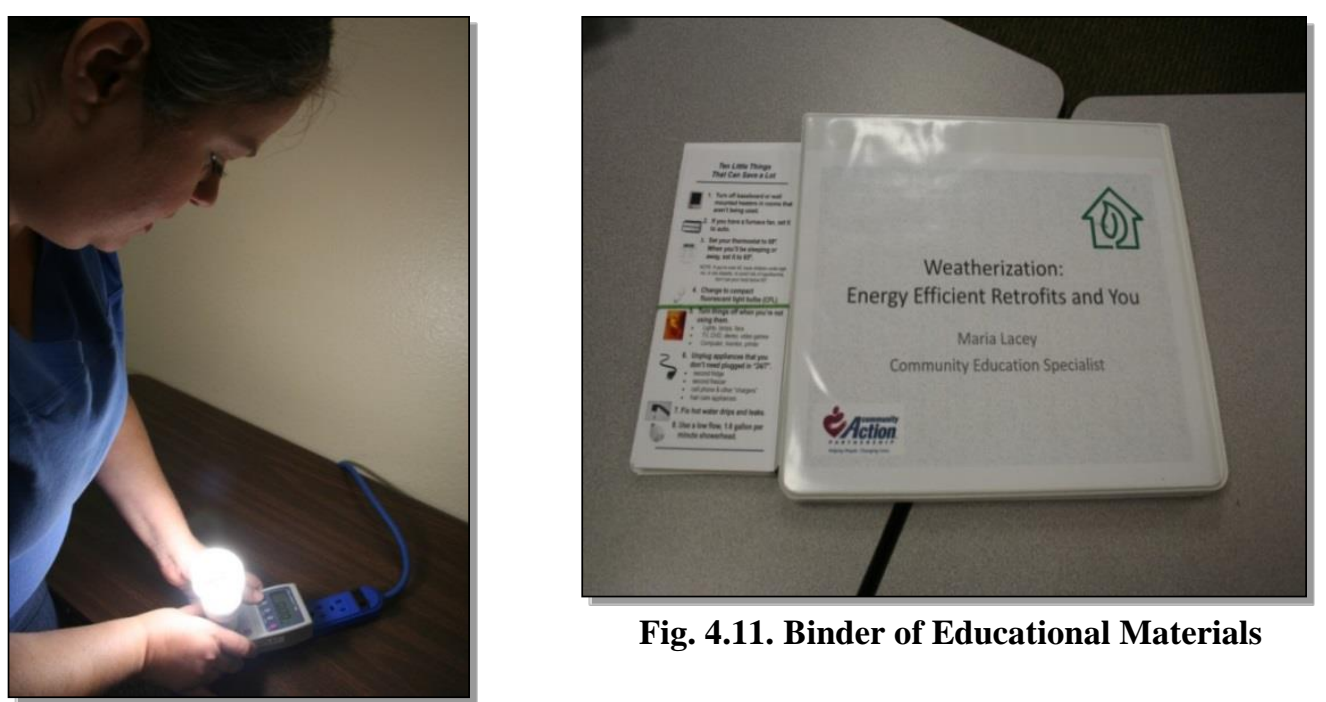

Fig. 4.11. Binder of Educational Materials

Fig. 4.10. Community Education Specialist, Maria Lacey with energy meter

To monitor the effectiveness of her client education, she asks clients at the end to complete a short survey about what they learned. Clients average a $65 \%$ positive rate to these three simple questions:

- I learned something new today about energy conservation.

- What was it?

- I will use what I learned today to save energy at home.

\section{Leveraging}

The Lewiston program has been very successful at leveraging with federal weatherization funds to get additional supplementary funding. Its most important partner is Avista Utilities, which provides natural gas and electricity services to five western states. Avista funding supplements WAP funding, providing $\$ 1$ million in 2010. Reportedly, the utility also contributes more money to CAP-Lewiston's low-income weatherization program as it increases utility rates, thus blunting to some extent the impact of rate increases on its poorer customers.

The Lewiston program's policies dictate that all energy-related measures installed with Avista Utilities funds must meet the Department of Energy's weatherization SIR, but there is no cap on the average amount of Avista funds that can be spent on weatherizing a home. Avista funds are also available to supplement DOE funds on health and safety measures as well as supporting the full-time home energy educator. The program has found this direct relationship between their agency and Avista to be both useful and important in its work.

Another example of leveraging is the agency's association with the Bonneville Power Administration, which also provides about $\$ 200,000$ in funding to the Lewiston Program per year. 


\subsection{ARRA PERIOD}

Before the ARRA period, the Lewiston program was able to weatherize between 270 and 280 units per year. With the addition of $\$ 7$ million in ARRA funding, the program completed 1026 units during the ARRA period. To help increase production rates and reduce administrative costs, a temporary office was opened in the northern part of the area, in Coeur d'Alene, Idaho. Four crews were based in this new office, and the number of crews based in the Lewiston office was increased from two to four. New weatherization staff, most of whom were assigned to the new office, was recruited via an employment agency. Highly skilled and experienced workers were available because the recession that started in 2007 had produced high levels of unemployment. The Lewiston program was able to buy 19 new trucks with ARRA money, replacing many old ones that had been costly to maintain. As ARRA wound down, the Coeur d'Alene office was closed during the late summer of 2011. The program plans to sell off several vehicles and maintain a post-ARRA fleet of about ten.

\section{Impact of Davis-Bacon Act prevailing wages provisions}

As with most weatherization agencies around the country, the prevailing wages provisions of the DavisBacon Act delayed the start of ARRA work by several months to around October 2010. Because of Davis-Bacon, the Lewiston crews received raises from around $\$ 9$ per hour to around $\$ 13$ per hour, but the Program does not foresee being able to maintain these labor rates post-ARRA. The office and salaried staff did not get raises. Because Davis-Bacon prevailing wages are set county by county, some rural weatherization agencies that work in multiple counties, like the Lewiston program, had difficulty managing all the different wage rates. The Lewiston weatherization program dealt with this by setting its labor rates to those of the highest rates paid in its Idaho counties, the rates in Kootenai County. Separate prevailing wage rates were needed for the agency's work in its Washington State county. It was reported that these rates were set by the state of Washington and were considerably higher than the Davis-Bacon rates determined by the U.S. Department of Labor.

The Davis-Bacon weekly labor time paperwork was particularly burdensome on the Lewiston program, which is small, but the agency discovered that some of its contractors already knew how to comply with the Davis-Bacon requirements. Still, all contractors knew they would not get paid unless they complied with the Act's requirements.

\subsection{LOOKING TO THE FUTURE: CONCERNS AND HOPES FOR THE PROGRAM}

The Lewiston weatherization program staff expressed hopes and concerns about the future of the program. First, they hope that the average level of investment in a home will remain at the $\$ 6500$ level set during the ARRA period since this level of investment allows some flexibility in addressing conditions found in homes and in dealing with any changes in the program that might substantially raise costs. The $\$ 6500$-per-home level also allows the Lewiston program to comply with state mandates concerning health-and-safety measures (e.g., smoke detectors). In fact, they would like to see the percentage of funding that could be allocated to health and safety raised.

They are also concerned about the incremental costs of the new ASHRAE 62.2 guidelines on home ventilation. The fans required under the new guidelines may cost between $\$ 500$ and $\$ 600$ initially per fan and may cost $\$ 15$ per year more in electricity costs to run. Because the fans will need to run 24 hours a day, 7 days a week, it is certain that they will break down, as all mechanical systems eventually do; in this case it is likely this demographic will not be able to afford this financial investment. 
The Lewiston program also has views on the eligibility threshold. During the ARRA period, the eligibility threshold for the federal weatherization program was raised from 150 percent of the poverty level to 200 percent. The Lewiston weatherization program would prefer for this threshold to be restored to the 150 percent level. Because LIHEAP eligibility is between 150 percent and 200 percent, almost all of their clients come through LIHEAP, so they do not have to do their own income eligibility check for those would-be clients who are not eligible for LIHEAP but might be eligible for the Weatherization Assistance Program. 


\section{SALISH AND KOOTENAI HOUSING AUTHORITY - PABLO, MONTANA}

\subsection{INTRODUCTION}

The Confederated Salish and Kootenai Tribes (CSKT) live on the Flathead Reservation directly north of Missoula, Montana (See Figure 5.1). ${ }^{8}$ The landscape is dominated by the Mission Mountains and Flathead Lake. The Flathead Reservation is extensive, encompassing almost 2,000 square miles (See Fig. 5.1). Lands primarily still owned by the Tribes circle the outside of the Reservation and are interspersed throughout the central areas.

According to the 2010 Census, just over 28,000 people reside on the Flathead Reservation with just over about 5,000 being tribal members and 2,000 members of other tribes. The Flathead Reservation has among the most diverse population of any Native American reservation in the United States. This diversity is, in part, the result of a period between 1910 and about 1930, when the U.S. Government passed legislation to allow non-Natives to homestead on the Reservation, and in part the result of the attraction of the well regarded Salish and Kootenai College.

The Confederated Salish and Kootenai Tribes' weatherization program operated by the Salish and Kootenai Housing Authority (SKHA) (See Figure 5.3), is located in Polson. The CSKT contracts with SKHA to serve registered tribal members from federally recognized tribes.

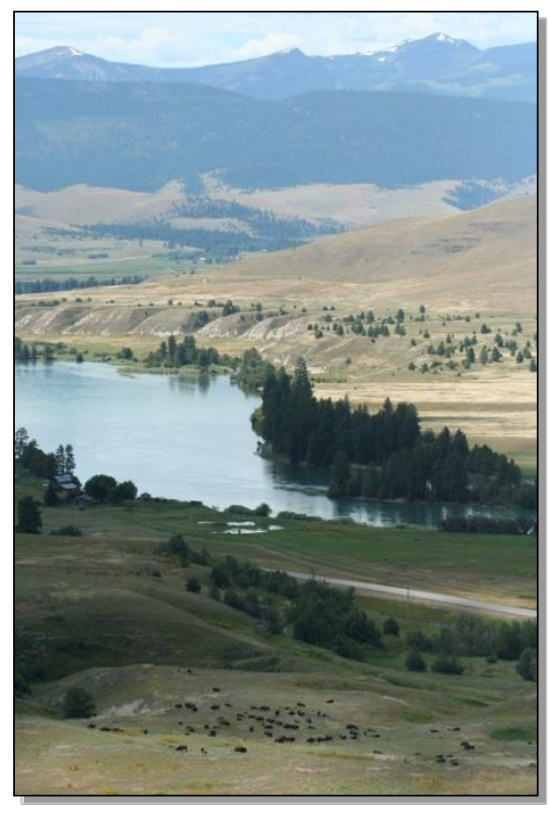

Fig. 5.1. Flathead Reservation

\footnotetext{
${ }^{8}$ See http://www.cskt.org/
} 


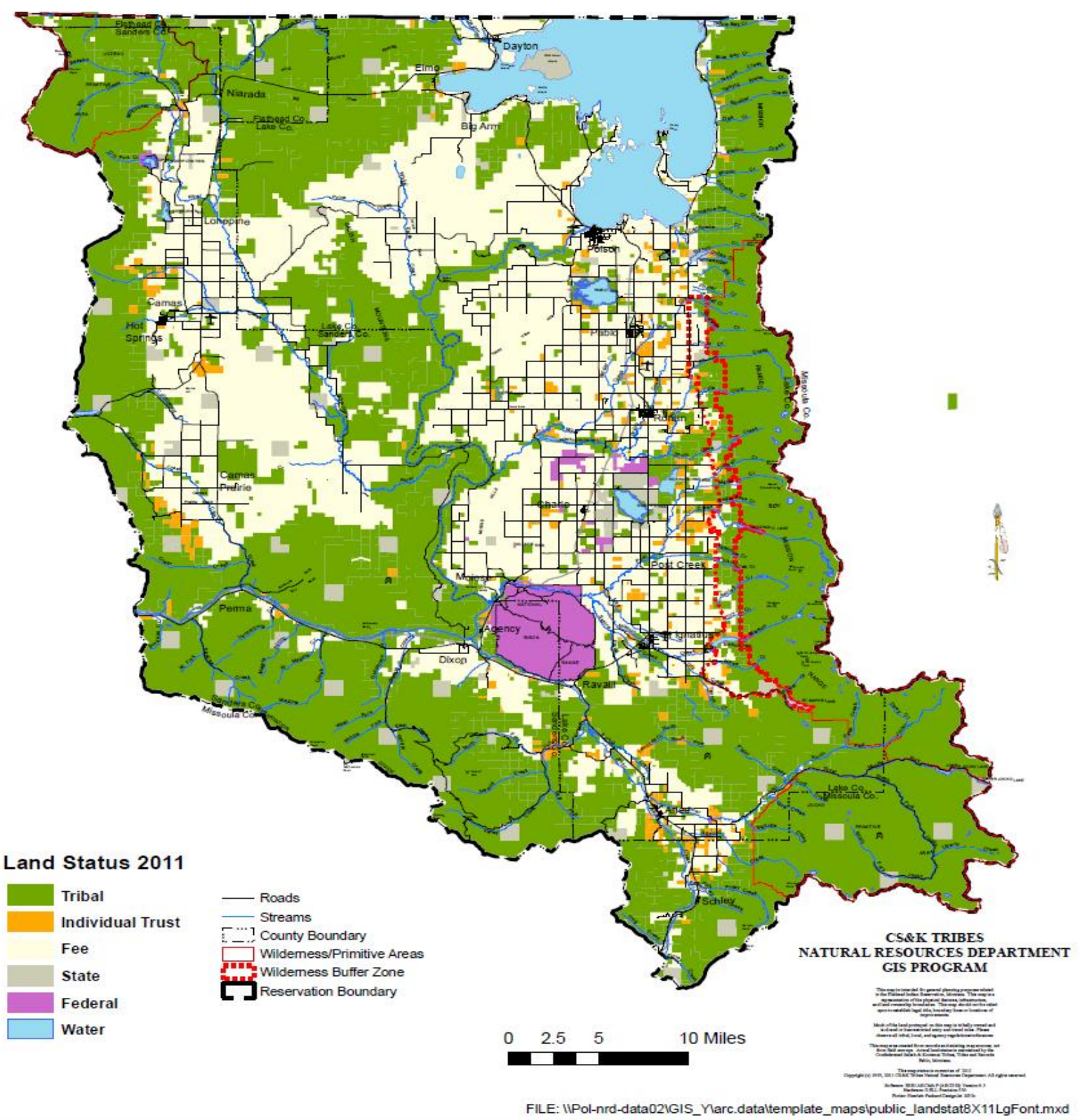

Fig. 5.2. Land of the Confederated Salish and Kootenai Tribes 


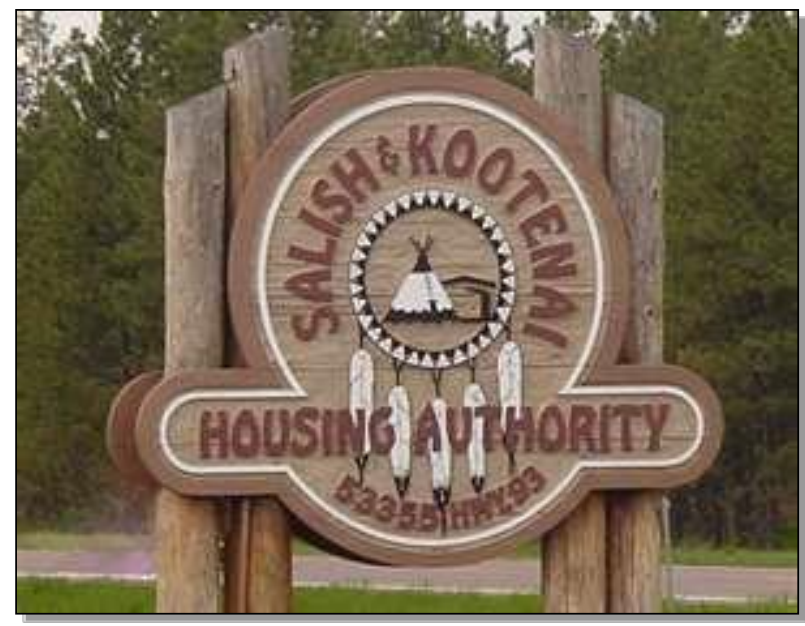

Fig. 5.3. SKHA located in Polson, Montana

\begin{abstract}
About 70 percent of SKHA's low-income clients are Salish-Kootenai tribe members. Its remaining clients are registered with other tribes. The SKHA weatherization program serves only registered tribal members from federally recognized tribes. Non-Native Americans seeking weatherization assistance must apply to local weatherization organizations that serve the four counties that intersect with the Reservation; Lake, Sanders, Missoula and Flathead.
\end{abstract}

The SKHA, established in 1963 by the Tribal Council and reorganized in 1985, offers a wide array of housing programs in addition to its weatherization program. ${ }^{9}$ It owns approximately 700 homes, manages a home mortgage program, conducts extensive home renovations, and has an emergency home repair program. SKHA is also able to obtain low-income tax credits and to sell them to a syndicate in order to raise money for new housing. In addition, SKHA has begun buying Federal Emergency Management Association (FEMA) trailers (See Figure 5.4 and 5.5) in Texas for transportation to the Reservation for resale to tribal members after the trailers are retrofitted to withstand the area's cold climate.

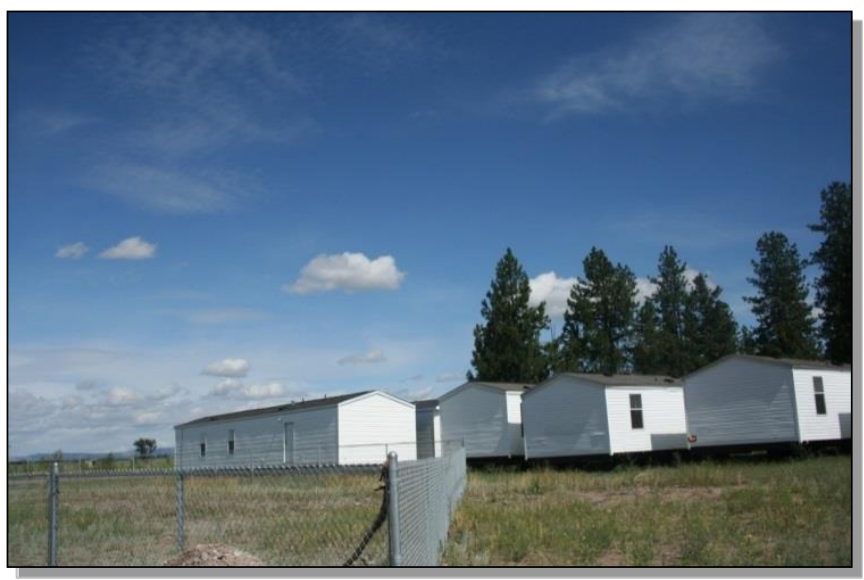

Fig. 5.4. FEMA Trailers Weatherized For Home Ownership

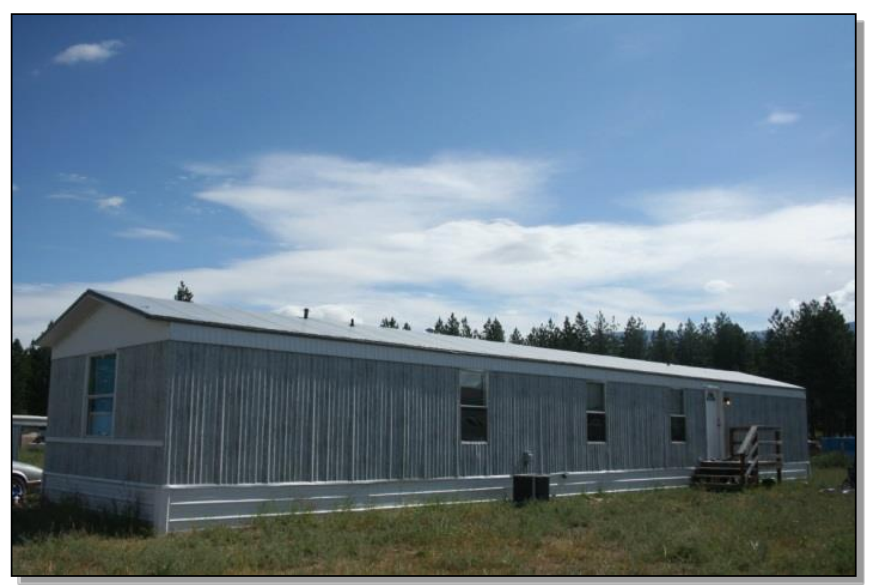

Fig. 5.5. Weatherized mobile home in SKHA's 80-lot trailer park

\footnotetext{
${ }^{9}$ See http://www.skha.org/
} 
SKHA reports that as a result of these and other initiatives encouraging home ownership, approximately 80 percent of tribal housing is owner-occupied. SKHA is particularly proud when SKHA clients move into "stick-built" homes, which can carry mortgages, rather than mobile homes, which cannot. Mobile home purchases are often financed through consumer credit at high and often predatory lending rates. Tribal members that make their income based rent payments to SKHA consistently on time, are identified as candidates for these home-ownership programs.

\subsection{SKHA WEATHERIZATION PROGRAM ORGANIZATION}

\section{Philosophy}

The SKHA's website states:

The mission of the Salish and Kootenai Housing Authority is to provide the highest quality, affordable housing to the people of the Flathead Reservation, utilizing all resources to insure that services are provided in an efficient, economical, and timely manner.

The SKHA weatherization program is small. In a normal non-ARRA year, it completes about 50 weatherization jobs per year. SKHA opted to be a Subgrantee to the State of Montana as opposed to the Program being operated as a Grantee through the CSKT. This is allowable because SKHA is not a formal entity of the Confederated Salish and Kootenai Tribes but is a separate non-profit organization. The State of Montana determines funding allocations for the Subgrantee in the state and therefore determines the projected number of units to be completed. The SKHA program service area includes four counties, all within the reservation's boundaries.

\section{Intake}

Although most clients already receive energy assistance through the Tribal LIHEAP, they apply for weatherization separately because the Tribe itself runs the former program and SKHA runs the weatherization program. However, tribal members are often referred through the energy assistance program, as well as through the Tribal Elders program. Typically, clients hear about weatherization and other assistance programs through what the Program Manager referred to as the "moccasin telegraph," or word of mouth. Applicants must travel to the SKHA office in Polson to apply and to prove their income eligibility. A priority ranking form is used to schedule home audits and then jobs (See Exhibit 5.2). Between 80 and 100 homes are usually on the waiting list.

\section{Process}

SKHA's Program Coordinator sets up the audit. SKHA has one auditor who visits the home and completes an in-house form. Information on the home is then entered into a computer audit tool developed by Northrup-Grumman and provided to SKHA (and other Subgrantee) by the State of Montana as the state's approved home-energy auditing tool. The audit software develops a list of measures that meet SIR requirements. Then the auditor develops a work order. Energy conservation measures (ECMs) that do not meet the SIR can lead to negotiations between SKHA and the contractors on the cost of measures to be installed. However, if costs do not meet investment limits, SKHA will attempt to utilize funds from other programs under the SKHA umbrella, such as the Elders Program or the Emergency Home Repairs Program, to pay for the measures on the work order. 


\section{Crews and Training}

The SKHA weatherization program is completely contractor-based, so when weatherization jobs are available, position descriptions are posted twice a week in the SKHA building in Polson for contractors to see. Contractors visit the building periodically to view new postings. To do weatherization work in Montana, contractors need to be certified as Level III, meaning that they have the requisite training, skills and work record to take on weatherization work, from blowing insulation to furnace replacement. However, they must have completed a certain number of Level 1 jobs (i.e., cleaning, painting, minor repairs) to be able to secure Level II and III (e.g. weatherization or "deep" rehab) jobs. SKHA owns over 700 units and has high renter turnover, creating a constant need for Level 1 workers.

The SKHA procurement officer arranges for "bid views," which are an opportunity for contractors to visit homes that are to be weatherized. Contractors are given the job descriptions, tour the homes, and then prepare their bids. The bid views help to improve the accuracy of job estimates.

Lower bids are usually accepted. However, contractors that are certified as an Indian Preference Contractor can win a bid if their bids are within 10 percent of the lowest bid, in compliance with the Indian Preference Laws. However, if the Native American contractor accepts the job, it has to be completed at the lowest bid price. Approximately half of the primary contractors for weatherization are certified as Indian Preference Contractors.

The contractors are responsible for doing all of the weatherization work in the homes, although they commonly hire their own subcontractors for specialty jobs such as furnace installation and repairs. The SKHA auditor/inspector is responsible for checking on the job while it is in process, and for final inspections and job closeouts.

Because many of the homes in the SKHA housing stock and on the reservation pre-date 1978, work requiring lead-safe weatherization practices are contracted out to experienced Level III contractors. SKHA offers training at its facility and has paid for its contractors to attend the trainings.

\section{Client Education}

At the time of the field visit, the SKHA was preparing to hire an Indian Community Development Block Grant (ICDBG) Home Maintenance Advocate to serve as a client-education specialist. Many households, when offered low-flow showerheads or faucet aerators, are reluctant to get them because they do not fully understand the benefits of water conservation as explained in the informational pamphlets handed out by the auditor.

\section{Innovations}

The Salish-Kootenai Housing Authority's WAP, like many weatherization programs, usually has a waiting list of potential clients. To decide fairly which jobs should have priority, the Tribe uses a Priority Points System (See Exhibit 5.2). The elderly, the handicapped, and households with large families, especially those with young children, receive priority points. The time that the household has already been on the waiting list is also weighed. The purpose is to make sure that the most vulnerable in the community receive help most promptly.

\section{Programmatic Issues}

Some from within both the tribal government and SKHA, have argued that it would be better for the Tribe to approach DOE directly to gain Grantee status and then contract with SKHA for weatherization 
services, instead of the agency's maintaining separate Subgrantee status under the State of Montana. At present, the Tribal government contracts with the SKHA for housing-related services. Because SKHA is a separate, non-profit entity, it can also contract directly with organizations other than the Tribe. While SKHA does benefit from technical assistance and program quality assurance services provided by the state weatherization program, the agency has found the paperwork and other state-mandated requirements burdensome. In addition, the state retains a substantial portion of training and technical assistance money. However, the Tribe has limited experience as a Grantee, and it is feared that direct DOE scrutiny might prove even more onerous. Working with the state as a Subgrantee also allows SKHA to benefit from any money provided by ExxonMobil Corporation to Montana. In the past, this money has been funneled directly into the weatherization programs.

Another issue that has been hard to resolve is whether to keep the contractor-based model or move to an in-house crew model. From an administrative perspective, the contractor model is quite expensive, as it requires SHKA to draft job descriptions and contracts, post job opportunities, answer contractor questions, vet potential contractors, travel to homes for bid views, oversee contractors on-site, deal with change orders, and negotiate with contractors to remedy any deficiencies. Having an in-house crew could reduce overhead while potentially increasing work quality. When funding is abundant, as during the ARRA period, having an in-house crew would be beneficial because the contractor base could work on larger, more lucrative jobs. However, the amount of weatherization work is not normally sufficient to keep an in-house crew employed full-time. Thus, SKHA has found that the contractor model provides staffing flexibility that a crew model does not. It appears that SKHA will retain the contractor model unless it gets a stable flow of increased weatherization funding that would justify an in-house crew model.

SKHA has had to consider, with the heightened administrative costs, whether participating in the WAP program is worth the expense. An external audit has suggested that more of these costs need to be charged to the WAP grant received by the State of Montana. So far, SKHA has maintained its weatherization program in adherence to its mission statement to utilize all resources available to help its constituents.

Some programmatic changes could make WAP more appealing to SKHA. For example, SKHA would like to install doors, refrigerators, and measures that may be deemed to be cosmetic but in reality benefit homeowners. SKHA would like to explore using priority lists to cut down on the time needed to input data into the audit software as required by the state. It might also help if they better understood how Montana allocates weatherization funding to its Subgrantee in general and to SKHA in particular. It could be that SKHA is eligible for more funding. If they were alerted to further funding possibilities from the WAP grant, they might be more likely to continue with the WAP program.

Other issues that were mentioned in the visit to SKHA included an expressed interest in adopting measures to reduce exposure to $1^{\text {st }}, 2^{\text {nd }}$, and $3^{\text {rd }}$ hand tobacco smoke impacting indoor air quality, in particular in their duplex or multifamily buildings. Also mentioned was a Montana State University program where 125 homes on the Flathead Reservation received radon testing kits and intensive education on indoor air quality. Partnering with MSU in promoting healthy housing and workforce development training on building science and home performance aligns with the direction DOE is moving the Program.

\subsection{LEVERAGING AND COLLABORATIONS}

SKHA regularly obtains funds from sources other than Montana WAP to invest in homes. Even during the intake process, the program coordinator will assess a household's eligibility for funding from all available housing programs. The main source of leveraged funds is the ICDBG from the U.S. Department of Housing and Urban Development (HUD). Leveraging WAP funds, SKHA obtains ICDBG funds (in 2010, SKHA received \$763,000 in ICDBG funds). ICD Block-Grant funds allow for some flexibility, to 
fund home renovations that go far beyond normal weatherization and DOE-allowable health-and-safety measures. However, at the time of the interviews conducted with SKHA, the ICDBG home rehab program had not been funded for over a year. Although the shortfall in funding makes it difficult to do comprehensive retrofits, SKHA focuses on working with what it has, while also trying diligently to secure additional funding. For example, in response to the reduction in funding from federal sources, SKHA adopted a Low Income Housing Tax Credit Program. However, only five out of 85 eligible tax credit units have applied for weatherization.

SKHA also receives approximately $\$ 80,000$ per year from the Bonneville Power Administration to subsidize measures to reduce electricity demand (e.g., new, more energy-efficient washing machines and replacement or new microwave ovens).

Other leveraged sources of funding for SKHA:

- $\$ 200,000$ in 2010 from the Bureau of Indian Affairs (BIA) for the Housing Improvement Program (HIP). The BIA funds were designated for the home rehab program and allowed up to $\$ 45,000$ in costs per unit;

- Small grants from LIHEAP for the installation of new windows;

- Mission Valley Power, which provides CFLs and clotheslines, with rebates for new windows and insulation;

- Ground source heat pumps in six SKHA-owned duplexes from the Bonneville Power Administration.

Although these projects are not partnered specifically with WAP, they demonstrate the level of regional and community consciousness on the issue of energy and water conservation that SKHA works to encourage.

SKHA programmatic and administrative staff seems acutely aware of the need to maintain relationships with leveraging sources during the ARRA WAP period. Although they lost some small funders, such as WARM Montana, they said they intended to continue on as usual with their primary funding sources to ensure the sustainability of their WAP and home-rehab programs. In fact, WAP is less attractive to the housing authority as a funding source than is ICDBG, as WAP offers limited dollars but requires a great deal of paperwork.

\subsection{REASONS FOR SUCCESS OF THE SKHA WEATHERIZATION PROGRAM}

The Confederated Salish and Kootenai Tribe is one of seven major tribes in Montana, but it is the only one with a weatherization program. Similarly, only three of twenty-nine tribes next door in the State of Washington operate weatherization programs. The factors contributing to SKHA's success are multiple. One reason may be that home ownership is a major goal of the Tribe and of the SKHA. Since the 1960s, when a tribal initiative established the Tribal Credit Program, and the 1980s, when SKHA was reorganized, programs have been operated to facilitate home ownership, a side effect of which is greater participation in and success of weatherization efforts. As a result the Tribe's efforts, the Salish-Kootenai confederation has a high home-ownership rate, around 80 percent, and programs like WAP work best in owner-occupied homes. Indeed, until recently, people living in HUD-owned or assisted rental housing were not eligible for WAP. 
A second reason for SKHA's success is its technical capacity; because SKHA is also involved in home renovation, it has been easy to develop the skills to successfully run the weatherization program. To help keep the contractors' skills sharp, SKHA has an established relationship with Montana State University, which runs workforce development and training courses.

Thirdly, because SKHA's mission explicitly states that it will use all resources available to it to help improve housing for the Tribe, the WAP weatherization program has been able to be successfully integrated into those efforts.

\subsection{ARRA PERIOD EXPERIENCE}

In two years, the SKHA weatherized 125 units with ARRA funding. Because SKHA uses a more flexible contracting model rather than in-house crews, ramping up production under ARRA was relatively straightforward. Only a second auditor needed to be hired. Local construction contractors were eager for the extra work because of the economic downturn.

The state provided SKHA with ample T\&TA funds during this period. SKHA took the opportunity to train its contractor base in several areas, including lead-safe weatherization and furnace repair and replacement.

\section{Davis-Bacon Act Compliance Issues}

As with most of the national weatherization network, the SKHA had difficulties at first with following the ARRA period Davis-Bacon guidelines. Wage rates were not the issue, though, because the prevailing wages set in the counties where most jobs are done, Lake and Sanders Counties, were set just above minimum wage. The contractors were already paying more than Davis-Bacon required. Random checks by SKHA staff at job sites confirmed this belief. Instead, the weekly payroll reporting requirement was the biggest burden.

\subsection{EXHIBITS}

\section{One Woman Army}

Doreena "Dee" Plant described herself as a one woman army. At the time of the case study visit to SKHA, Dee was the weatherization program's only auditor and inspector (See Figure 5.6). Sadly, Dee passed away unexpectedly from an infection in her lungs one month after our visit.

Dee's path to her job at SKHA was circuitous. In 1988, she left the Flathead Reservation and joined the Navy, where she worked on HVAC equipment as a machinist mate. After leaving the Navy, she lived in Florida, Georgia and North Carolina, where among other jobs she delivered mail, before returning to the reservation. Hired by SKHA during the ARRA period, she apprenticed under a seasoned auditor/inspector. When this person moved on, she inherited the job.

Carolina, where among other jobs she delivered mail, before returning to the reservation. Hired by SKHA during the ARRA period, she apprenticed under a seasoned auditor/inspector. When this person moved on, she inherited the job.

As described herein, the SKHA weatherization program is small and completely contractor based. Dee's main responsibilities were to conduct audits and inspections. Her goal was to conduct about three audits per week, which could take place anywhere within the immense Flathead Reservation. After each audit, she entered her findings into the auditing software, which would then inform her which measures meet 


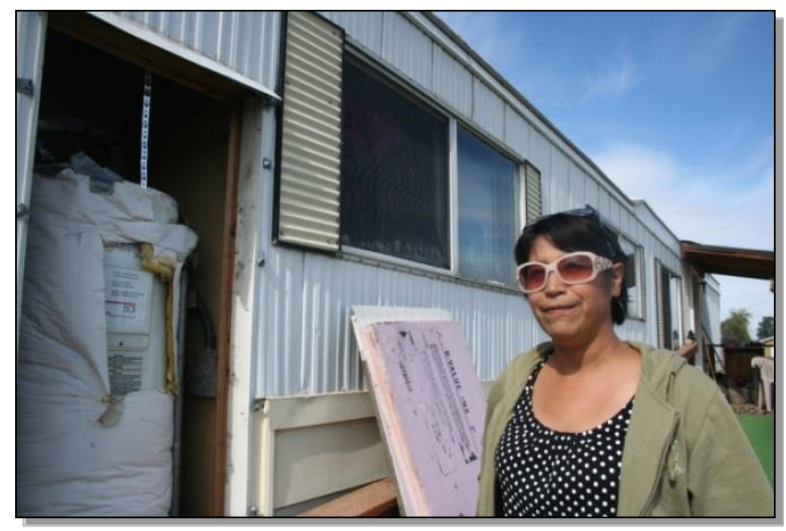

Fig. 5.6. Doreena "Dee" Plant (1966-2011) describing SKHA's weatherization process

the SIR. Then, she prepared a job description for the contractors to consider. She was proud that she had gotten the former process down to about an hour and a half and the latter down to an hour. She attended all the bid reviews; SKHA allowed/required interested contractors to view the homes with the job descriptions in hand in order to better inform their job cost estimates. She frequently visited homes during the jobs to 'ride herd' on the contractors. During inspections, she would call contractors to come back to fix things; if they didn't they would get written up. She would have between 10-30 open jobs at any one time.

Her interactions with the clients could be quite intense. While touring their homes she inquired about their health and well-being. Sometimes clients' answers would lead her to investigate the presence of mold or malfunctioning systems emitting dangerous levels of carbon monoxide (CO) into the homes. She always asked the clients what they would like to have done in their homes, energy-wise, while also reminding them that final decisions depend on cost-effectiveness considerations. In addition to energy efficiency, she always looked for major mold and repair issues and would refer clients to other SKHA programs as appropriate, such as their senior and home renovation programs. She carried applications for these other programs with her. She hated to walk-away from a home but did so with serious mold issues. Dee spent a good deal of time discussing many ways to save energy in the home, from turning off lights to switching off power to major systems when not in use. She also trained clients how to change furnace filters and clean refrigerator coils.

Dee knew that women are a minority in the weatherization field and never hesitated to take the opportunity to prove herself. She figured she would eventually earn the respect from the male-dominated contractor crews because she enjoyed crawling through crawlspaces and climbing into attics. She also said it helped to be something of a 'techy' (e.g., she always had her laser ready to measure the dimensions of mobile homes). She knew her trade but was interested in professional growth and improvement. For instance, she had begun using a new roof sealant for mobile homes and worked to improve her methods for installing flashings around windows and doors and in the corners of the perimeters of mobile homes (See Figure 5.7 and 5.8). 


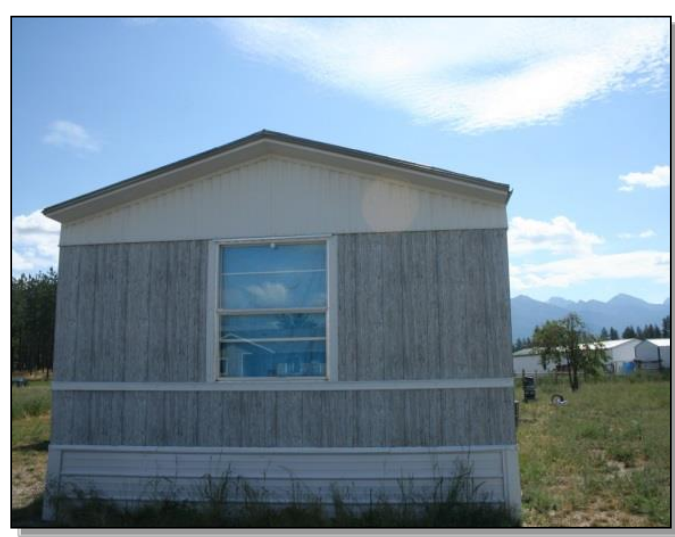

Fig. 5.7. Flashing around the perimeter of a mobile home

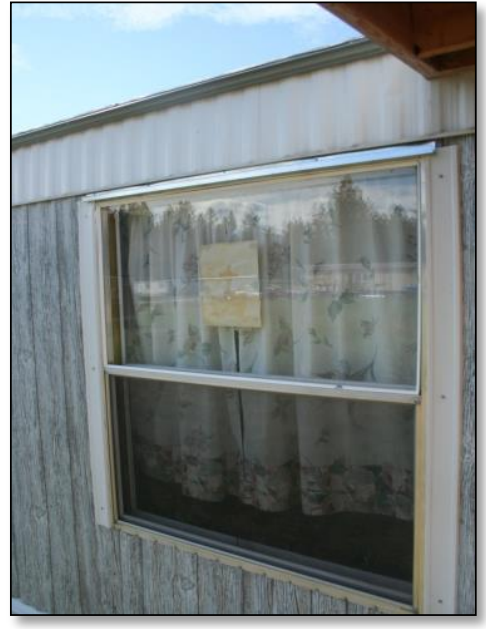

Fig. 5.8. Flashing above a window and around the perimeter of a mobile home

While she had earned the respect of her contractors, Dee would have liked to have her own crew that could take care of details immediately while on-site if not taken care of initially.

Auditor, inspector, contract manager, technical specialist, energy educator, health advocate, life-long learner; she was truly a One-Woman Army. 


\section{Exhibit 5.2 Weatherization Priority Point System}

\section{Salish \& Kootenai Housing Authority Weatherization Program Priority Points System}

Please review each item and write the number of points next to the item that applies to the applicant.

Handicap

(30 Points)

Elderly

Household Size

Children

Children 2 \& under

Children 3 to 5

Children 6 to 18

LIHEAP/Fuel Assistance Recipient

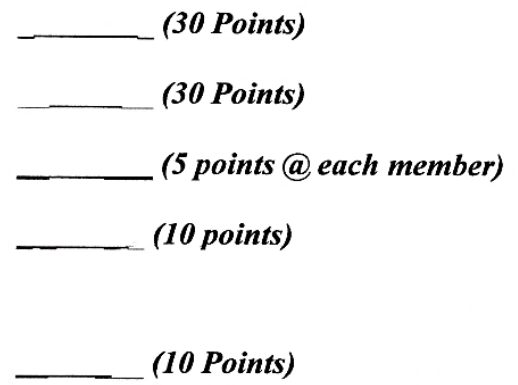

Time on waiting list

12+ Months

(10 Points)

10-12 Months

(8 Points)

7-9 Months

(6 Points)

4-6 Months

(4 Points)

1-3 Months

(1 Point)

Emergency

(20 Points)

Comments:

Date:

Total Points:

Evaluation done by:

Michelle Marigeau 



\section{HELP OF SOUTHERN NEVADA - LAS VEGAS}

\subsection{INTRODUCTION}

HELP (Housing, Emergency Services, Life Skills, and Prevention) of Southern Nevada is a nonprofit agency started by the Junior League of Las Vegas and incorporated in 1970 in Clark County, Nevada. HELP provides a broad range of social services to help with poverty, homelessness, addiction, and other societal problems. Since 1992, it has also provided weatherization services (See Figure 6.1).

HELP's area is home to approximately 2 million people - nearly three-quarters of Nevada's population. Burdened by foreclosures, a depressed construction industry and a decline in tourism, Nevada has had the nation's highest unemployment rate within the past several years; in September 2011, the rate was 13.4 percent. ${ }^{10}$ Within Clark County, 12 percent of families with children under 18 and 8 percent of people 65 and above have an income below poverty level. ${ }^{11}$

Between July 2005 and April 2011, HELP has provided weatherization services to close to 8,000 dwellings $^{12}$; of its roughly 17,000 clients, approximately 4,200 have been seniors, 3,400 disabled and 2,200 children. HELP estimates that the energy saved because of weatherization services has amounted to close to 29 million kilowatt hours or \$4 million in utility bill payments since 2005 .

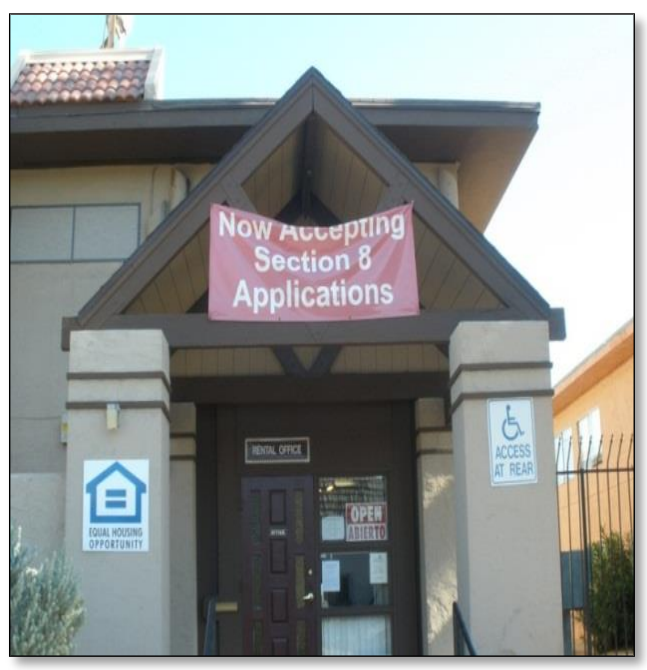

Fig. 6.1. Multifamily building complex weatherized by HELP

\footnotetext{
${ }^{10}$ Bureau of Labor Statistics, 2011

${ }^{11}$ U.S. Census Bureau, 2009

${ }^{12}$ 2,695 dwellings were completed in '09 -'10 ARRA period
} 


\subsection{OPERATIONS}

HELP successfully integrates its weatherization program with its 10 other types of services to fulfill its mission to help clients in any way possible. For example, the LIHEAP program provides clients with energy assistance once a year, but it also requires that the clients apply for weatherization services.

Not all weatherization programs are part of a mission as large as HELP's is. All 53 HELP employees are outreach-certified, so they are authorized, for example, to take weatherization and food-stamp applications, to refer children to services, to authorize rent assistance, and to refer clients to workertraining programs. Thus, weatherization staff and contractors-all trained to be observant and to ask questions if necessary - are in a unique position to be able to suggest and enroll clients for other services from which they could benefit. HELP's call center, for example, can link to the national 211 referral service.

HELP's weatherization team works four 10-hour days, allowing it to serve clients more conveniently with extended "after-work" hours and decreasing its administrative costs by 6 percent.

\section{Deferrals and Walk-aways}

HELP very rarely encounters a project where a walk-away or deferral is required. Of the deferrals that do happen, almost all of them are due to severe mold or moisture issues. HELP does not have a home-rehab program to help clients with major structural damage but they can refer their clients to another program called Building a Better Tomorrow. Upon completion of the repairs, HELP will return to begin the weatherization. The agency "walks away" from projects in the following circumstances: where structural damage causes safety issues, where duct work or a cooling system are nonexistent, where there are insect infestations, or where there are signs of illegal drug use in the home.

\section{Agency Expertise-Multifamily Units}

This agency serves a relatively high volume of MF units or apartment buildings. Weatherizing multifamily units costs less per unit, allowing the agency to invest more money in single-family homes when needed. From 2011-2012, 59 percent of its projects were MF units, up from 40 percent before the ARRA period. Because weatherizing multifamily units is so cost-effective, HELP of Southern Nevada has used its existing network of clients from other programs to locate eligible multifamily buildings. HELP has found that owners of MF buildings, whether private or nonprofit, often supplement WAP funds to get weatherization measures installed in the common areas of their apartment complexes.

Unfortunately, income qualification procedures can hamper efforts to weatherize MF dwellings, as 66 percent of a building's residents have to qualify under low-income guidelines for the MF unit to get weatherization services. Owners will sometimes try to weatherize a building cost-free under WAP only to raise the rent on its tenants or even evict them. For that reason, DOE requires that stipulations are incorporated into its agreements with MF unit owners that no WAP-weatherized dwellings may be subject to rent increases or evictions for a negotiated period of time after weatherization.

\section{Crews and Training}

Before 2005, HELP employed an in-house crew model, but during a boom in the local casino construction business around that time (and consequent challenges with employee turnover) the agency opted for a contractor-based model; concerns about liability issues and possible unionization of their crews also drove the move to contractors. At the time of the site visit, HELP employed four union and four nonunion contractors who worked together. HELP's contractors are paid their fees based on the measures installed. The state has established a recommended cost per measure and has also developed a general 
priority list that HELP is required to work with. For small jobs (less than $\$ 2,500$ ), bids can be bypassed and a project can be started immediately. HELP has been careful not to dilute the contractor base, so the number of contractors and the number of homes in the pipeline are balanced to keep the former well employed. In order to retain these employees post-ARRA, HELP is planning on establishing a fee-forservice program for homes that may not be eligible for WAP and to this end, the program has completed a business plan that has already been approved by its board.

All of HELP's contractors are certified in Lead Renovation, Repair and Painting (LRRP) and lead-safe weatherization training, as required by the state. Many homes in the coverage area were built before 1978, so lead testing is often performed (See Figure 6.2). Because of the high risk of lead exposure in older homes, HELP tries to avoid replacing windows as a weatherization measure.

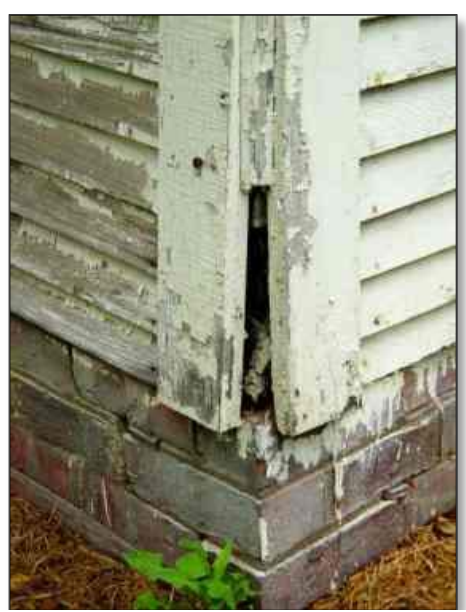

Fig. 6.2. Home testing positive for lead

To assure quality control, all HELP-weatherized buildings are inspected the day the project is completed; in addition, HELP's Building Performance Institute (BPI)-certified inspectors perform a Quality Assurance (QA) test-out on 15 percent of weatherized homes, including blower door measurements. If the installed measures do not pass inspection, the repairs and/or corrections are paid for by the contractor.

Contracting companies are required by the state to have at least 50 percent of their crew complete a training program. After completing training, they also must serve an apprenticeship with field staff at the Nevada Housing Authority until they are approved to work on their own.

\section{Typical Weatherization Installations}

Most weatherization measures designed for cold climates translate well into Nevada's oppressively hot and dry climate with the exception of envelope sealing. Many homes in Las Vegas have "up-ducts" placed in the ceiling; these "up-ducts" allow pressure created by evaporative cooling appliances to escape into the attic space rendering envelope sealing ineffective.

HELP has a flexible fund for emergency situations in which air conditioners, critical to vulnerable clients, are necessary. In addition, solar screens are installed on all projects if windows face the sun which can reduce solar heat gain in a house by 85 percent (See Figure 6.3). Although new air conditioners cannot be installed where none exists, $\mathrm{A} / \mathrm{C}$ units over 15 years old can be replaced with a more efficient unit. Duct sealing is performed on every central $\mathrm{A} / \mathrm{C}$ unit, old or new. 

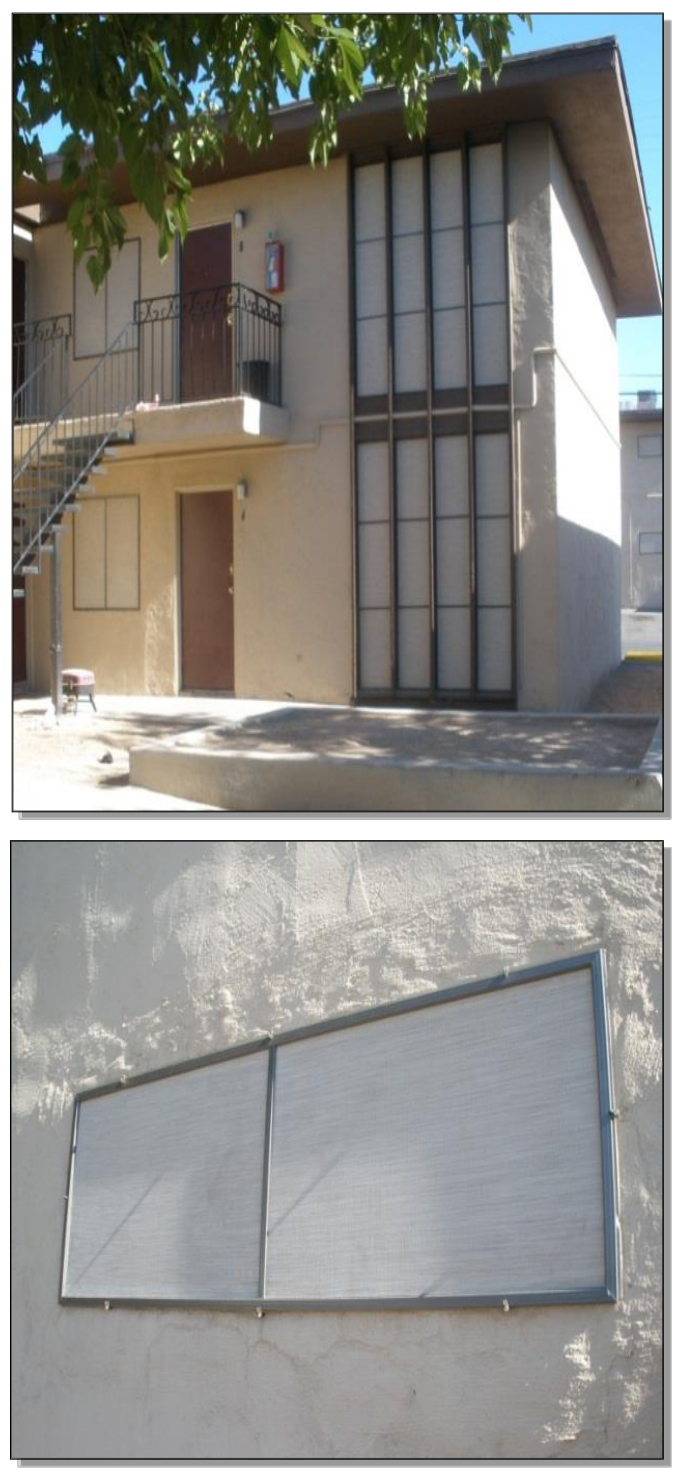

Fig. 6.3. Multifamily unit with solar screens installed (top); close-up of solar screens (bottom) 


\section{Client Education}

HELP requires all contractors to do in-field client education. Crews explain the why and how of completed weatherization measures and diagnostics performed, i.e. CO, blower-door, and duct leakage testing. They also discuss issues and topics that clients might not be aware of; such as, the concept of base-load, the need for changing furnace filters once a month, cleaning refrigerator coils, and thermostat set-backs (i.e., using programmable thermostats to automatically change settings by time-of-day). Contractors supply informative booklets provided by Nevada Energy and give out a series of coloring books for children.

\section{Leveraging}

At times, HELP is able to leverage minor repairs with its emergency repair programs. HELP gets an allocation from the Housing Trust Funds, which are state taxes on home sales (10 cents for every $\$ 500$ of house value). These funds are unrestricted; therefore, they can be used for some weatherization measures that are not allowed by DOE, such as returning to a house to repair a new A/C unit or helping with electric/plumbing services. They may fill in funding gaps with these Housing Trust Funds or refrigerator rebate money if warranties have expired or labor costs are too high. However, HELP does not have any utility monies to tap into.

\subsection{ARRA PERIOD}

Since it is the largest weatherization agency in the state, HELP received 67 percent of all of Nevada's ARRA funds; it received close to $\$ 11$ million in 2009, $\$ 7.3$ million in 2010, and $\$ 880,000$ in 2011. In addition, the agency was awarded a $\$ 7$ million DOE SERC (Sustainable Energy Resources for Consumers) grant in this time period (e.g., to install super-evaporative coolers).

The initial goal in FY 2009-2010 (the first year of ARRA funding) was to weatherize 1222 homes, but 2700 homes were completed in six months, including 1,800 multifamily units - a dramatic rise from preARRA years, when only 700 single-family homes and $200 \mathrm{MF}$ units per year were average numbers. After the ARRA period, the agency anticipates cutting back to around the same level as before, although the SERC grant that HELP was awarded during the ARRA period will extend some benefits into the future - as part of the grant contract, contractors return to SERC homes for three years to instruct and do maintenance if necessary (See Exhibit A). Some SERC measures installed include solar water heaters, heat pump water heaters, PV rooftop panels, in-home energy monitors, and high efficiency evaporative coolers (Coolerados $\left.{ }^{\mathrm{TM}}\right)$.

In order to handle the greater volume of work during the ARRA period, HELP increased its weatherization staff from 4 contractors, 2 inspectors, and 11 staff members up to 7 contractors, 8 inspectors, and 23 staff members, hiring only individuals who were unemployed at that time. It is estimated that the contractors, in turn, hired a total of about 165 people to complete their crews. In addition, HELP invested in newer, more fuel-efficient vehicles (See Figure 6.4), replacing several older vans; the newer vehicles have saved the agency money on gas and maintenance fees. 


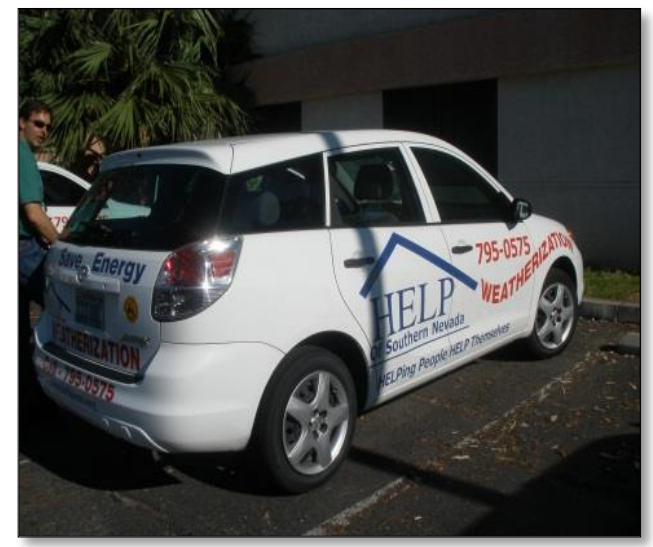

Fig. 6.4. Fuel-efficient van purchased with ARRA funding

\section{Davis-Bacon Act Compliance}

The Davis-Bacon Act has not been a great problem for HELP's weatherization department to incorporate because the prevailing wages for contractors called for in the Act were already lower than typical wages paid in Clark County. Because some of HELP's smaller contractors were not accustomed to the weekly reports, the agency hired a staff member who specialized in Davis-Bacon reports to walk the contractors through the weekly reports until they were familiar with the process, as well as distributing digital copies of information on all the relevant civil-rights regulations and all required forms. Under the constraints of Senate Bill $152^{13}$, HELP was to hire only contractors who had completed training; since there was only one training center up and running in the state at the time; this regulation was said to be burdensome.

\section{Concerns for the Future}

HELP staff expressed great concern about the implications of the new 62.2 ASHRAE standards: "It makes it challenging to provide the best service to our clients when we receive less funding while more regulations are being implemented." They do not feel that utilizing a mechanical apparatus to provide continuous ventilation is cost-effective or necessary in their hot-dry climate. The staff also expressed the following:

- Frustration with state-mandated priority lists from which they cannot deviate

- Frustration with state regulations regarding weather-stripping, which is only an allowable measure if a gap is inordinately large, in excess of a $12 \mathrm{in}^{2}$

- Would like to see an allowance for repairs or maintenance

- Would like to see a percentage of budget allocated for "re-weatherization"

- Would like to see more lenient regulations on trading out old refrigerators with ones that are more energy-efficient.

\footnotetext{
${ }^{13}$ SB 152 is a Nevada law that pertains to ARRA incentives to provide job training, the promotion of energy efficiency and the promotion of the use of renewable energy in Nevada. The bill requires the Department of Employment, Training and Rehabilitation, and the Housing Division of the Department of Business and Industry to establish contractual relationships with nonprofits to provide training in the areas of weatherization, energy retrofit applications and performing energy audits. These contracts are required to provide that the contractors employ a certain number of trained employees and pay them prevailing wages and that contractors provide employees on the project and their dependents with health-care insurance. (Source: http://www.leg.state.nv.us/75th2009/Bills/SB/SB152.pdf)
} 
However, on the whole, HELP believes that WAP is moving forward; the increased caps on average unit costs have allowed for a more comprehensive weatherization program.

\subsection{PROFILES}

\subsubsection{Active Homeowner Participation}

One requirement to get SERC-financed installations is the occupant's willingness and ability to perform maintenance and upkeep on the installation(s). The pictured residence received a closed-loop solar water heater in which an ethyl glycol/water mixture is heated by the rooftop-mounted solar panels (See Figure 6.5); the water then goes down to a storage tank with a heat exchanger, inside the home's laundry room (See Figures 6.6 and 6.7). During the visit, the homeowner was actively involved and said how impressed he was with the constant supply of hot water, which had only minor temperature fluctuations throughout the day. In addition, HELP installed a Coolerado ${ }^{\mathrm{TM}}$ unit, a super-evaporative cooler, also roof-mounted. This was a much bigger unit than the original cooling unit and does require regular maintenance, so the homeowner needed to be physically capable of climbing up on the roof to change the filter. In some instances, neighbors have complained about the aesthetics of these large units visible on the rooftops. Although, some homes received new super-cooling units that were mounted on the ground, which were less noticeable and provided better access for maintenance. Other neighbors have expressed only curiosity and interest in the Coolerado and solar panels.

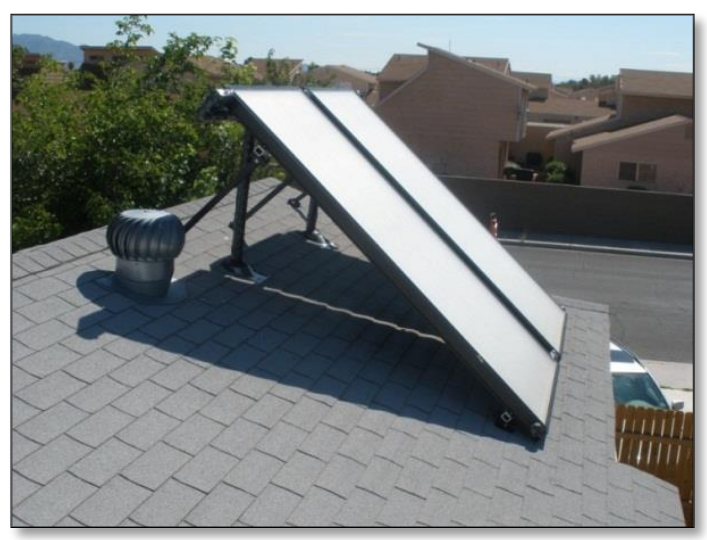

Fig. 6.5. Rooftop solar panels 


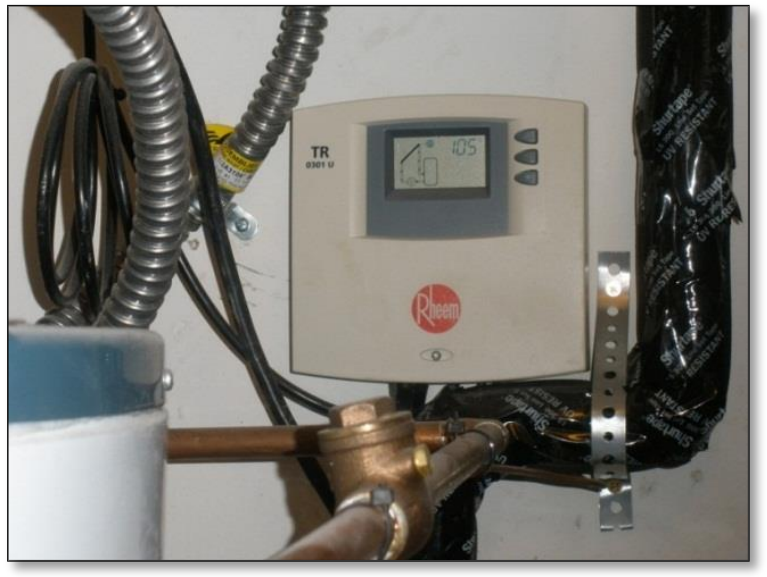

Fig. 6.6. Temperature of water tank with rooftop solar water heater

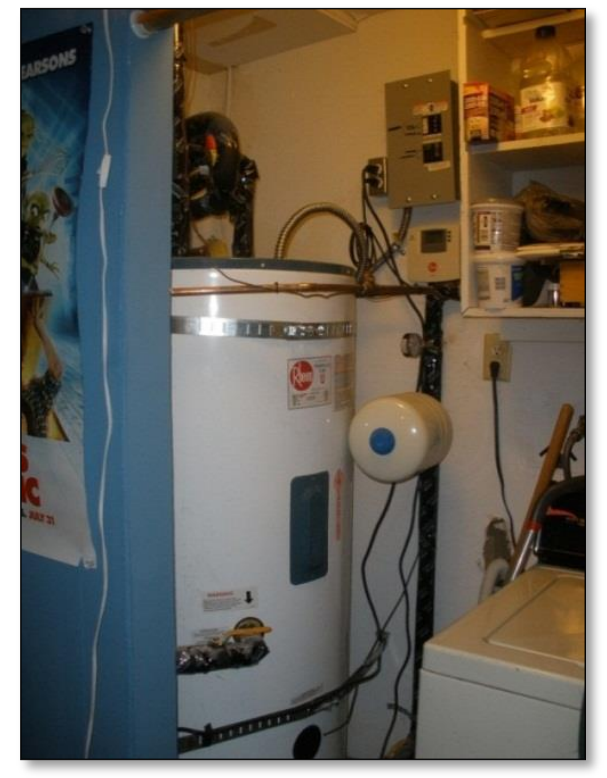

Fig. 6.7. Solar water-heater tank 


\section{COMMUNITY ACTION HUMAN RESOURCES AGENCY - ELOY, ARIZONA}

\subsection{INTRODUCTION}

Community Action Human Resources Agency (CAHRA) of Pinal County, Arizona provides specialized community action services, including weatherization, to a 5,369-square-mile area that is larger than the state of Rhode Island. CAHRA is the only CAP agency in Pinal County, which has a population close to 400,000. Because of its large territory, CAHRA is said to be the "best-hidden program in the entire county." CAHRA's office is located in tiny Eloy; from there, crews may travel up to two hours to perform a weatherization job. The City of Apache Junction, one of the original retirement communities in Arizona, where they often provide services, is 1.5 hours away.

The private, non-profit corporation highlights its "thirty years of innovative programming and collaboration focused on improving the lives of low-income people and their communities." Fourteen percent of the county's people are in poverty status, with 14 percent of those above 65 years of age and 27 percent less than 18 years old.

CAHRA was included in this group of case studies because it is a strong weatherization program in a region with a hot, dry climate (See Figure 7.1) and because of its efficiently organized administration.

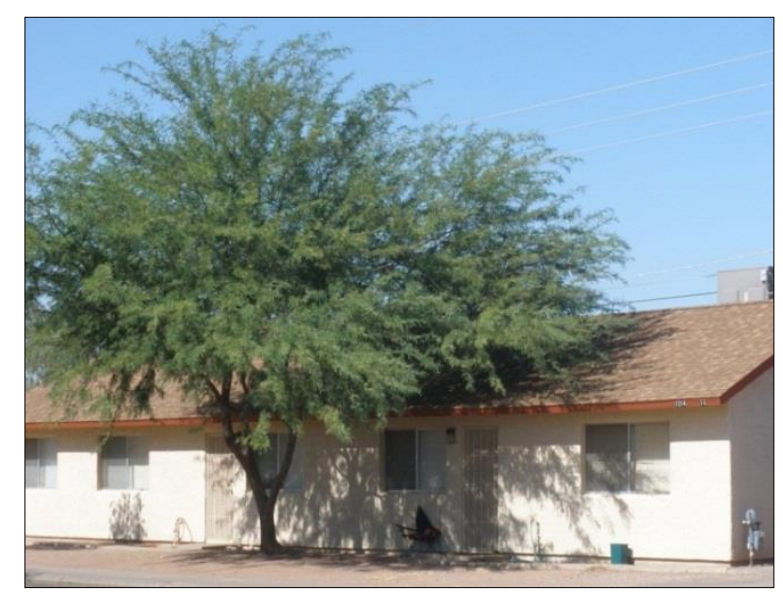

Fig. 7.1. Multifamily unit weatherized by CAHRA; only shade tree in the complex.

\subsection{PHILOSOPHY AND OPERATIONS}

CAHRA has a total of 32 employees, 8 of whom specialize in providing WAP services. "People helping people" is CAHRA's motto. One staff member stated that working for a CAP agency is the embodiment of being of service and is dedicated to making a difference in people's lives, to fighting the effects of poverty, and to making an extra effort to treat clients as they would treat their own families. Such importance is placed on sensitivity in all client interactions that CAHRA requires "sensitivity training" for newly hired contractors so that they can serve income eligible clients effectively and with compassion. 


\section{Process}

An indicator of the staff's dedication to customer service is present with the client's first phone call with the Intake Specialist, who clearly has a knack for building a rapport with the client. She helps the client navigate CAHRA's various social-services programs. Many clients are unaware of the variety of programs available through CAHRA. The intake specialist aims to walk the client through every program offered, and make referrals to programs the client could benefit from.

The intake process is completed by telephone, eliminating the need for the client's physical presence at the office, streamlining the application process, and increasing the client's comfort level. Many clients have never needed to apply for assistance before; for some it can be a humbling and daunting experience without a compassionate advocate.

The weatherization application is reviewed by the Housing Programs Manager and, if approved, is then ranked according to need. During the ARRA period, there has generally been no waiting list, and the maximum time required to complete a weatherization from intake was, as of the 2011 site visit, about 60 days. This is a significant improvement from the pre-ARRA period, when nearly 50 households were commonly on the waiting list.

The Coordinating Specialist arranges the funding sources and coordinates contractors for the duration of the job, keeps in contact with clients, and informs them of the time and date of each visit and who the contractor(s) will be. Every effort is made to minimize the number of visits for the client's convenience, but it typically takes four to five visits to complete a weatherization job from initial audit to inspection. Having one staff member who focuses exclusively on finding leveraging funds and coordinating the contractors helps expedite the process.

\section{Audit}

Before the initial audit, a "welcome packet" is mailed to tell clients what to do to prepare their house for the audit and the weatherization measures. For the audit itself, the crew utilizes both Residential Energy Modeling (REM) Design software and a general priority list (GPL). Walk-aways are rare and occur only if a house is ineligible for weatherization due to structural damage.

\section{Installations}

Weatherization in this climate focuses on protecting people from the extremely high temperatures of the area, which present serious health risks to those in a compromised physical condition or the elderly. Typical in-house measures include duct sealing, envelope sealing, shading of sun-exposed windows, installation of sun screens, and health and combustion appliance safety tests for CO and natural gas leaks. There are certain state level constraints on the replacement of appliances. Refrigerators are replaced about 50 percent of the time. However, CAHRA uses WAP funds only for measuring the existing refrigerator's energy use; they then can use Utility Repair Replacement Deposit (URRD) money for the replacements. Similarly, CAHRA can repair the HVAC systems as an allowable measure but they no longer can replace the unit. Because of this, they have kept a small supply of portable air conditioners for temporary use when cooling units are beyond repair. These air conditioners are truly lifesavers in the summer months when temperatures exceed 110 degrees.

\section{Client Education}

Client education is high on CAHRA's list of priorities; a Partnership Agreement which covers client expectations as well as how they can increase energy savings in their home, is discussed with all clients and signed (See Appendix A), and an informative booklet entitled "Your Home Energy Savers Book" is 
provided to them. In addition, when crews visit, the crewmembers explain warranties on installed appliances, discuss thermostat settings, and talk with clients about when and why to change HVAC and air filters. After the installations, follow-up calls are made to answer questions and evaluate customer satisfaction.

\section{Crews and Training}

CAHRA uses a combination of in-house crews and contractors. At the time of the site visit, CAHRA had 11 contractors under contract. Beginning with the ARRA period, contractors were informed of the prices set by the state of Arizona per weatherization measure and asked to commit to a one-year contract. During the site visit, 18 homes were waiting for weatherization, nine of which were to be outsourced as they were located far from Eloy and would require too much travel time for the Eloy-based crews. CAHRA often outsources the jobs that are farther away from Eloy, in Apache Junction for example. CAHRA "subs out" measures that require licensed contractors, such as repairing and replacing HVAC systems, electric work and plumbing.

The weatherization staff's documentation and tracking system is well organized and effective even though it is still paper-based. Each client's folder has a checklist and every required form is tabbed and labeled in order of usage. This folder accompanies the contractors on each site visit.

\section{Leveraging}

CAHRA's goal is to leverage money most effectively to meet the SIR requirement to do the most weatherization with available funds. The creative and tenacious efforts of CAHRA staff to leverage multiple funding sources allow them to install more measures and perform more repairs. However, in December of 2010, due to state budget cuts, CAHRA lost the Emergency Home Repair Program as well as the Housing Trust Fund. These sources had assisted with roof and plumbing repairs.

Despite that setback, CAHRA has retained several avenues to leveraging additional funds for its clients. Three local utility companies assist with the costs of providing weatherization measures: Arizona Public Service (APS), the Salt River Project, and Southwest Gas. Each utility company has its own income requirements for eligibility, with Southwest Gas and APS requiring clients to be at $150 \%$ of federal poverty level and Salt River at $200 \%$.

Additional sources that may be utilized are the Utility Repair Replacement Deposit; the Area Agency on Aging; and LIHEAP. For one weatherization job that required extreme rehabilitation at a cost totaling $\$ 47,430$, CAHRA was able to leverage a remarkable six different sources of funding.

\subsection{ARRA PERIOD}

The ARRA period saw a significant increase in employment from 20 to 32 staff members. The weatherization staff was increased from two full-time and one part-time up to eight full-time employees. Under ARRA, CAHRA was contractually obligated to weatherize 275 units with ARRA funding, as opposed to only 44 homes per year before ARRA. With the additional ARRA funds, at the time of the case study, 220 homes per year have been successfully weatherized.

With ARRA funding, CAHRA has been able to expand its efforts into weatherizing two shelter homes; a Domestic Violence Center and a Children's Crisis Center. The agency had to increase its staff, expand its training requirements, and learn how to comply with Davis-Bacon reporting requirements to make the transition to larger dwellings. This was done with the already increased production made possible through ARRA, (CAHRA hired an employee in 2010 to work exclusively on Davis-Bacon reporting). 


\section{Concerns/Suggestions Post-ARRA}

The agency is pleased that the average cost ceiling has been increased to $\$ 6,500$ as well as the household income threshold being increased from $150 \%$ to $200 \%$ of the Poverty Income Guidelines; these increases allow CAHRA to have a more significant positive impact. However, the agency has concerns that the state is restricting allowable measures and becoming more regimented and less flexible. The agency would like to include Pinal County's tribal reservations as a portion of its client base in order to broaden its efforts on behalf of its income-eligible citizens. In general, CAHRA believes it is effective at helping these citizens in significant ways, and if allowed flexibility, could be even more effective. Concern was expressed regarding Arizona establishing a new general priority list that will significantly reduce allowable measures.

CAHRA's Housing Programs Manager also expressed concern about what will happen to CAHRA's weatherization clients, especially the elderly, when ARRA funds are depleted. When asked about suggestions for improvements in the program, she said, "We just want to be able to keep the program in operation! Who will help these seniors that are dying from extreme heat exposure? These hot temperatures kill people just as easily as cold temperatures do. It seems impractical that the agencies located in hot, dry climates receive fewer funds than those in the colder climates."

\subsection{PROFILES}

7.1. National Church Residences (NCR) are multifamily homes for elderly, disabled, or low-income citizens. The 42-unit NCR in northeast Pinal County was working on weatherizing the apartments in the complex, but CAHRA was able to add funding and labor to much improve the weatherization project. Residents had been sweltering in apartments that had three or four window AC units each but were still uncomfortably hot. CAHRA installed ductless mini-split units that provide both heating and air conditioning. Mini-splits have an outdoor compressor/condenser and an indoor air-handling unit, so they can be used in multifamily housing or for a home retrofit where installing ductwork is not feasible or practical. In addition, CAHRA installed insulation and sealed the envelope of the apartment units. In the Arizona heat, keeping temperatures at comfortable levels can be a matter of life or death. With the CAHRA weatherization measures, NCR residents' homes are now at consistently comfortable temperatures.

7.2. A grandmother and granddaughter living in the town of Oracle were referred to CAHRA. The granddaughter had been suffering from lethargy and constant flu-like symptoms that had puzzled her doctor because the symptoms would dissipate when she went outside. CO poisoning had not been considered. During the initial audit, CAHRA performed a CO test, and the results showed levels at 200 ppm (nearly six times the level that OSHA deems to be able to cause symptoms of toxicity ${ }^{14}$ ). Four out of five of the gas appliances were leaking gas. The furnace and water heater were replaced, and a $\mathrm{CO}$ alarm installed. The granddaughter is now healthy and symptoms of CO poisoning have disappeared.

7.3. A single mother and two young children were living in a trailer whose central air conditioner and refrigerator were broken. The trailer was located in the middle of a sandy lot with no shade trees or structures to block the blazing sun (See Figure 7.2). The woman was employed as a caretaker but still could not afford the repairs required. She would buy a small supply of food every day and store it in a cooler. The family lived and slept in the living room, where there was a small window AC unit, to survive in the summer temperatures, which often soared over 100 degrees. Before the trailer was weatherized,

\footnotetext{
${ }^{14}$ According to OSHA standards, CO becomes toxic when it reaches a level higher than 35 ppm with continuous exposure over an eight hour period. When the level of $\mathrm{CO}$ becomes higher than that a person will suffer from symptoms of exposure. Mild exposure over 2-3 hours (a CO level between 35 ppm and 200 ppm) will produce flulike symptoms such as headaches, sore eyes and a runny nose.
} 
indoor temperatures were so extreme that the 5-year-old girl suffered chronic nosebleeds. An inefficient gas furnace caused fuel costs to average $\$ 500$ a month in the winter. CAHRA installed an HVAC unit and a refrigerator. With more moderate indoor summer temperatures at 82 degrees, the little girl's nosebleeds have stopped.

7.4. An elderly couple was living in a home whose roof was rotten in several places (See Figure 7.3). They were referred to CAHRA through the Emergency Home Repair program due to the condition of their roof. Previously, the wife had a car accident that led to the loss of her job and confinement to a wheelchair; subsequently the husband quit his job to take care of her. Living on a fixed income, and with the need to spend their disposable income on health care; they could not afford home repairs. In addition to the roof that needed to be replaced, CAHRA's assessment found a ceiling that had caved in, visible insulation, large gaps between windows and walls, and mold. On further investigation it was found that the doors had rotted out and the water heater was malfunctioning. The home was structurally weak, its trusses and supports also weakened by rot.

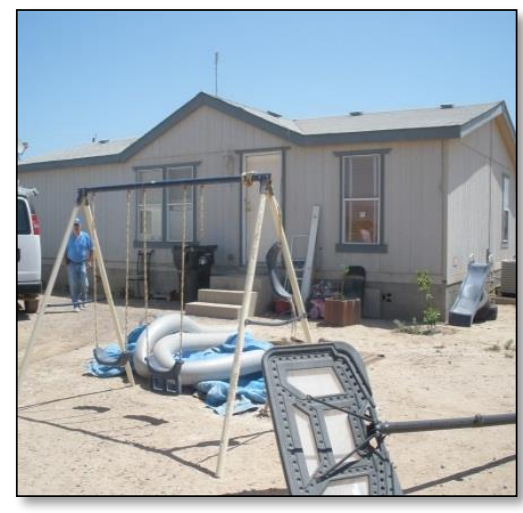

Fig. 7.2. Trailer without shade, in hot/dry climate
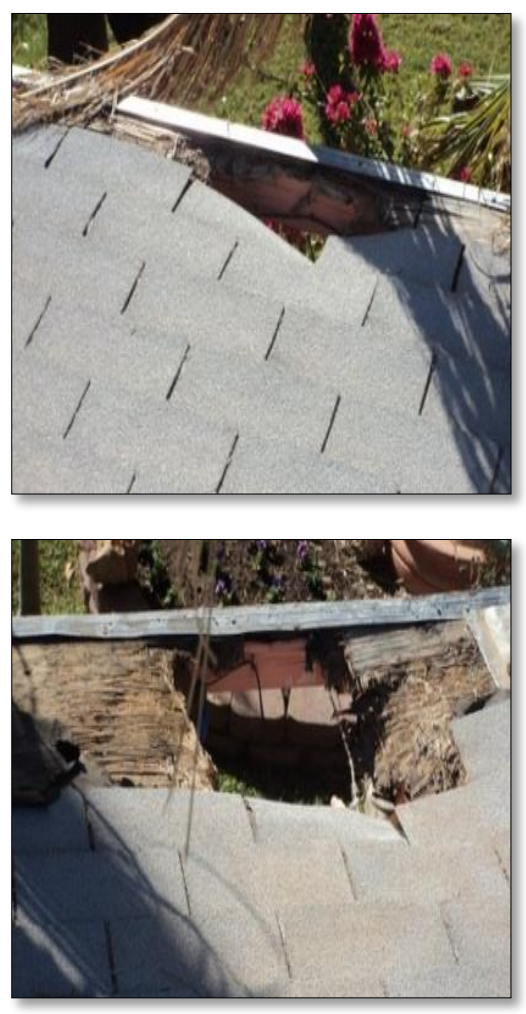

Fig. 7.3. Roof damage 
CAHRA staff pulled together six funding sources to widen the doors for wheelchair access; install handrails in the bathroom (See Figure 7.4 and 7.5); replace the roof, windows, and doors; repair the HVAC ductwork; insulate; and install a new water heater. This extreme rehabilitation project totaled $\$ 47,430$; the state of Arizona and DOE conducted a desk audit on this project because of the extent of the work.

Funds to make this couple's home habitable came from the following sources: 1) $\$ 22,555$ from DOE/ARRA which included HVAC replacement, ventilation in baths and kitchen, general housing rehabilitation, insulation, door replacement, and repair to ceilings to support insulation; 2) $\$ 14,780$ from Housing Emergency Home Repair, for roof and drywall repair; 3) \$2,000 from URRD for part of the HVAC replacement; 4) \$1,500 from the Area Agency on Aging for general repair; 5) $\$ 3,000$ from Southwest Gas for a hot-water heater and part of the ceiling repair; 6) $\$ 4,380$ from LIHEAP for duct replacement.

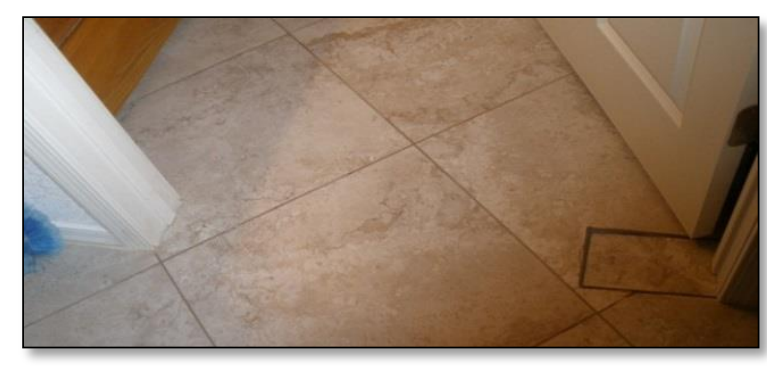

Fig. 7.4. Expansion of doorway for accessibility (after repair)

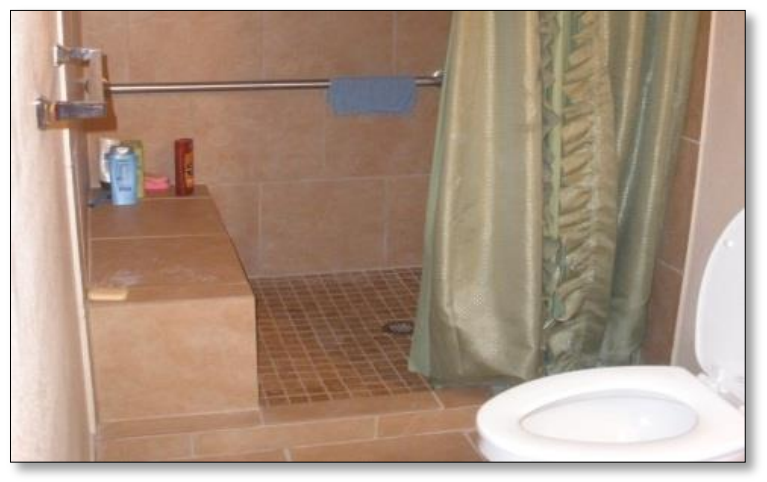

Fig. 7.5. Handicapped accessible shower stall

7.5. CAHRA's weatherization of the shelters owned by Against Abuse, Inc., a non-profit, constituted several "firsts" for the agency: first shelter project, first domestic violence center project (See Figure 7.6), first children's crisis center project, first solar project (See Figure 7.7), and first ARRA project. The nonprofit's funding had been reduced for the second year in a row and it had a hard time controlling its electric bills in its combined locations. After consultation with the Arizona Department of Commerce Energy Office, it was determined that solar water heaters would help with the electric bills. In addition to the replacement of the water heaters, the weatherization included the installation of room pressure relief vents, Energy Star freezers and refrigerators, solar screens on the windows, a locked programmable thermostat, duct sealing; and two central A/C units. The total cost for weatherization was $\$ 25,000$, with the solar systems installed by Integrated Solar, Inc. and priced at \$14,000. By October 2010, the women's shelter's electricity bill had decreased by almost $\$ 155$ per month. 


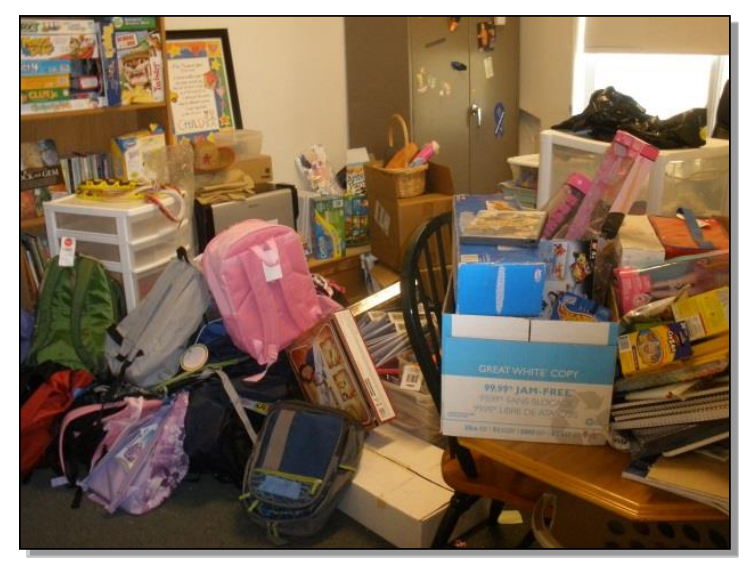

Fig. 7.6. Women's and Children's Shelter, room for donated supplies

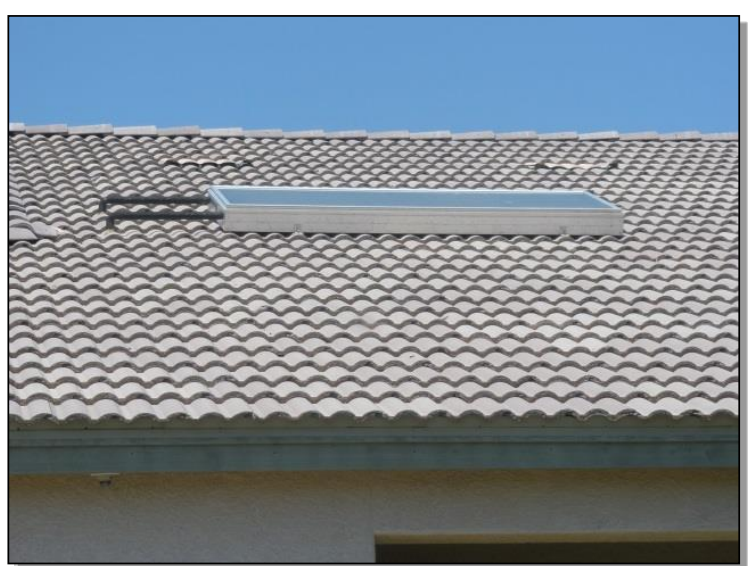

Fig. 7.7. Solar panel for Hot water heater on roof of Women's and children's Shelter 



\section{OPPORTUNITY COUNCIL - BELLINGHAM, WASHINGTON}

\subsection{INTRODUCTION}

Bellingham is a city of over 80,000 residents in Whatcom County, located south of the Canadian border on the west coast of Washington State (See Figure 8.1). The area has a mild, rainy climate; it is reputedly the U.S. city with the fewest days of sunshine per year.

The Opportunity Council (OC), a community action agency located in Bellingham, exists to "help families and the community become self-sufficient and stable." Founded in 1965 as a direct product of the Economic Opportunity Act during the Johnson Administration, the OC serves three counties in the western coastal region of Washington: Whatcom, Island, and San Juan. The OC has 175 full- and parttime employees and provides services to more than 18,000 people each year in seven major arenas: early childhood education, childcare, food and nutrition, community services, shelter programs, partnership programs, and energy and home repair. The latter program includes the following subprograms:

- Energy Assistance Program

- Conservation Education

- Weatherization Program

- Home Repair Program

- Building Performance Center

- Community Energy Challenge

- Lead Hazard Reduction Program

- Healthy Homes Program

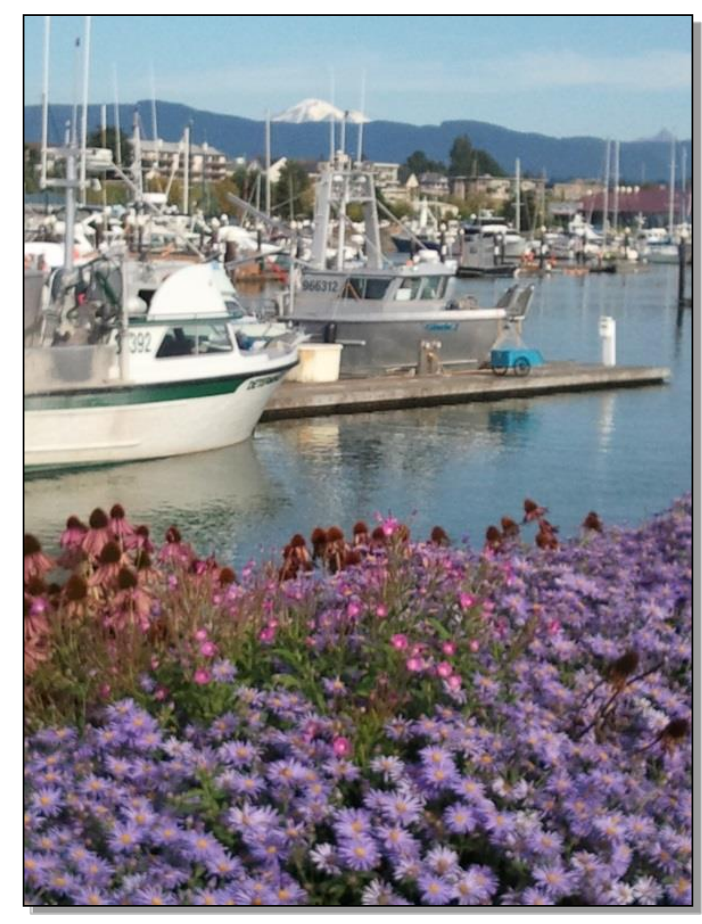

Fig. 8.1. View of Bellingham, WA

The weatherization program, in turn, focuses on four core elements: the health and safety of home occupants; the structural durability of homes, efficiency and affordability of energy use in homes, and comfort issues such as warmth. 


\subsection{PHILOSOPHY AND OPERATIONS}

According to the OC's Mission Statement, "The Opportunity Council is a private, non-profit human service organization that acts as a catalyst for positive change, both in the community and in the lives of the people it serves." See Figure 8.2.

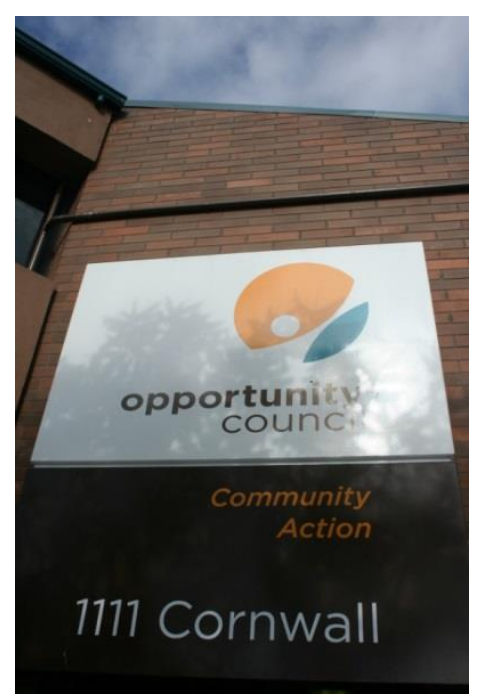

Fig. 8.2. Opportunity Council Office

The OC is dedicated to providing "wrap-around services" for each family that it serves. This requires networking within the agency and among various programs funded by different sources. Like other similar agencies, the OC integrates all of its services. For example, if a family applies for Head Start, then the OC will determine whether the family also needs Energy Assistance, weatherization, or other Healthy Homes measures. As a community action agency, OC provides its staff with training on poverty as well as ongoing professional development related to working with the clients who seek assistance through their programs.

\section{Weatherization Model}

Before the ARRA period, the OC employed an in-house crew-based model, only contracting out electrical and plumbing work. However, during the ARRA period, contractor crews were hired to ramp up production in response to higher levels of funding. It is unclear what crew model the OC will use post-ARRA.

\section{Operations}

The Energy Assistance Program is the hub of the OC's weatherization and home-repair programs. Approximately 5,000 households received help with home repairs, energy bills and weatherization from the Energy Assistance Program in 2010. There is no official waiting list for weatherization services; the OC just pulls names from the Energy Assistance lists as production rolls along. The OC project coordinator oversees all aspects of the weatherization process, from assessment to project closeout. 


\section{Intake}

Households are screened using a variety of filters: elderly or disabled clients; those who are disabled or who have young families; Native American families; clients with high energy bills or a high energy burden; clients who need conservation education; and clients who are eligible for the Weatherization Plus Health program receive different degrees of prioritization based on these factors.

When a household is accepted for weatherization, OC's "No Orphans" policy applies; this means that no client is left to wonder what comes next or what to expect throughout the weatherization process from intake to final inspection. Regular meetings occur with OC staff for scheduling, client education, project coordination and final inspection. The client is kept apprised at all steps in the process.

\section{Pre-Audit Client Visits}

The OC has recently implemented a new program to conduct pre-audit in-home visits. These visits are conducted by well-trained energy assistants (See Profile 1). Each energy assistant spends two to three hours in the home with the client(s), addressing energy use as they walk through the home (See Figure 8.3 and 8.4). The energy assistants provide energy education and energy savings tips to the clients and install some simple energy-efficiency measures, such as CFL light bulbs. The education specialist identifies the top three energy savings priorities and works with the client to set realistic goals for their family. Then the energy assistant may or may not refer the home to the weatherization program, depending on the condition of the home. About 20 percent of the homes audited do not need further weatherization assistance and are "weeded out" at this stage. Of the 80 percent remaining, another 20 percent normally are deferred until house repairs can be made.

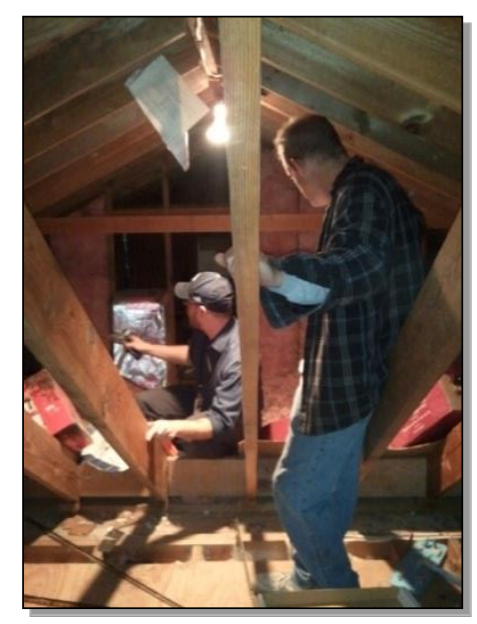

Fig. 8.3. Pre-Audit walk-through of attic with client

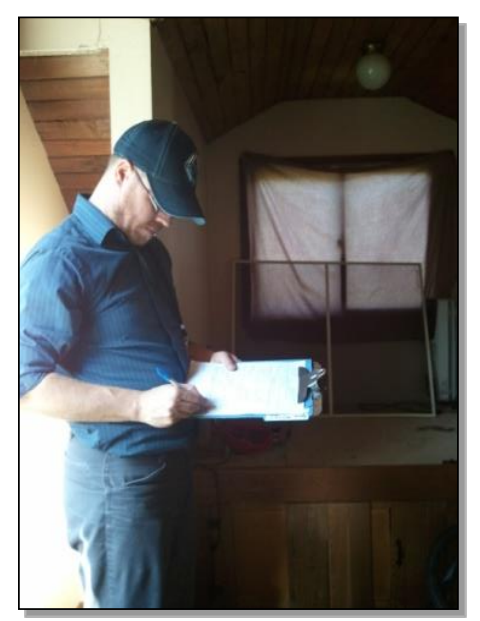

Fig. 8.4. Energy Assistant completing the pre-audit check-list

The energy assistant position was created because the agency realized that WAP in general and OC's weatherization program specifically lacked effective energy education. The OC's weatherization crews were trained in the technical application of weatherization and were skilled in this area, but did not have 
either the interpersonal skills or the interest to talk extensively with occupants about how to use energy more wisely. The energy assistant position is currently filled by staff members who are trained to make weatherization referrals to auditors, decisions regarding deferrals, and to start the dialogue with occupants about energy use that will then be reinforced throughout the rest of the weatherization process.

\section{Audit}

The estimated cost of weatherizing a home is developed at the time of the audit. Cost estimations are based on the recommended weatherization measures plus the number of projected crew hours. Crew hours are figured with office and overhead expenses, insurance costs, etc., built in. The OC typically uses a priority list for DOE-weatherized homes, but will use TREAT auditing software if the home presents a more complex challenge, or Earth Advantage, a privately developed spreadsheet tool by Michael Blasnik.

The majority of the homes weatherized by the OC are all electric (electricity is furnished by Puget Sound Energy, an investor-owned utility), although many homes also burn wood for heat. Approximately 70 to 90 percent of the weatherized homes receive new space heating appliances.

\section{Quality Control}

All jobs are inspected by an independent inspector (not a project coordinator) in order to comply with DOE guidelines, BPI specifications, and State of Washington Department of Commerce standards and specifications. Typical problems involve combustion safety, which drives the Building Performance Center (See below) to offer refresher courses on combustion appliances. The quality control inspectors report directly to the weatherization director to prevent conflicts between production needs and quality.

The OC also administers program feedback surveys for performance measurement, continuous quality improvement and as a tool for ongoing needs assessment. They also administer quality-of-life surveys to homeowners in order to measure owner perceptions of improvement in such areas as asthma triggers.

\section{Leveraging}

The Opportunity Council actively leverages its federal weatherization dollars. In fact, approximately 15 percent of its annual weatherization budget is provided by regional utilities. Success in acquiring utility funding is due, in part, to the state of Washington's Energy Project, housed at the Opportunity Council. Through this initiative, the OC participates in utility rate cases. When a utility company in its service territory moves to raise energy rates, the Opportunity Council steps in to advocate on behalf of the lowincome population and communicates the needs and strategies for saving energy and money for this population. Based on the OC's testimony, funds for low-income weatherization can be built into utility rate increase. Although this strategy has been effective, OC notes that rate increases are now more frequent, occurring three to four times per year instead of just once per year, as was the case a few years ago.

In addition to leveraging funds to assist its clients, OC leverages its expertise in low-income weatherization to provide home retrofit services to the non-low-income community. One program for doing this is called the Community Energy Challenge. At the heart of this program is a $\$ 1.2$ million revolving loan fund that provides low-interest loans, in the 1-2\% range, to incentivize homeowners to do home retrofits. The Building Performance Center (BPC) trains local contractors to do the audits (and energy performance scoring) and to prioritize weatherization measures for the homes. The OC also links private-sector contractors to local lending institutions. At the time of the site visit, over 500 energy assessments had been conducted, with an estimated 300 households going forward on their retrofits. 
Lastly, as noted above, the Opportunity Council is active in applying for grants from various state and federal agencies as well as private sector foundations and benefactors.

\subsection{WEATHERIZATION AND HOME REHAB}

"Sometimes you need to fix the home first in order to eventually get to the saving energy piece." -- David Finet, Executive Director

The Opportunity Council is committed to addressing housing repair and other issues interfering with energy efficiency; this involves identifying and attracting home repair funds that allow a comprehensive home repair and energy efficient retrofit. The average home repair project costs around $\$ 25,000$ per home. While some believe that it is more cost-effective to weatherize multifamily units, the OC will repair and then weatherize mobile homes, sometimes investing as much as $\$ 10,000$ in a mobile home. The OC argues that since it costs about $\$ 200,000$ to build a multifamily building, it is worth the money to fix mobile homes instead of abandoning them to build multifamily units.

The OC has repaired as many as 85 homes in one year but at present only has funds for 10 home repair projects per year. However, it has some home-repair funds that can be bundled with weatherization projects or used separately. For example, the Home Repair Program targets sub-standard housing and addresses concerns with electrical and sewage systems. Other sources for home-repair funding include a Community Development Block Grant, the Washington Trust, and the U.S. Department of Agriculture's Housing Preservation grant fund.

The OC also gives deferred loans to low-income households to fund repairs, with the loan due when the house is sold. The OC takes a second position on the mortgage. When the homeowner moves or dies, or if the house is sold or is refinanced, the loan is repaid, and this money is returned to the program. The OC currently holds approximately $\$ 1$ million in outstanding deferred loans.

\subsection{WEATHERIZATION PLUS HEALTH}

The Weatherization Plus Health program was started in the early 1990s after OC representatives at a meeting with Native American tribal leaders noticed that the elders of the tribe were using inhalers and discussing the asthma rates prevalent in their tribes. Many tribal homes had electric baseboard heat and wood stoves. Mold was often observed around the colder perimeter of the homes. In 2002, the Indoor Air Coalition of Whatcom Co. decided that WAP should add indoor air quality to its portfolio since the program was already in homes completing audits and addressing ventilation. OC received a U.S. Department of HUD Healthy Homes grant to work with a consultant in developing the Weatherization Plus Health protocol. Now, a private foundation finances the Weatherization Plus Health program for homes that have one or more asthmatic children under the age of six, and DOE has adopted the program name Weatherization Plus Health with permission of the OC.

The Weatherization Plus Health concept is integrated into each of the OC programs and is considered by the each of the program coordinators when assessing family needs. The energy assistant completing the initial assessment of the home is the ones who often identify the home (particularly when it must be deferred because of outstanding issues) as a potential Healthy Homes or Weatherization Plus Health project. Both energy advocates and lead technicians are trained to identify asthma triggers, such as the presence of rodents, insects and dust.

The Community Services department, which delivers the Energy Assistance program (a primary source for both weatherization and Healthy Homes referrals), schedules the weatherization pre-assessment and then the weatherization itself. While most opportunities to make homes healthier are identified through 
the Energy Assistance pre-assessments, the OC also receives direct referrals for Healthy Homes projects through its Head Start and early-learning programs.

In addition to DOE's interest in weaving Healthy Homes protocols in with energy efficiency, the Opportunity Council has worked with the state of California and EPA in designing their program and in continuing to connect the Healthy Homes, indoor air quality, and energy retrofit programs. Although the original HUD grant targeted homeowners and child-care providers, renters are now eligible for Weatherization Plus Health as well. The Opportunity Council is now considering what other populations should be targeted for Healthy Homes assessment and action, as well as where agency partnerships might prove effective. Individuals with emphysema or other respiratory illness are strong candidates; so are "hoarders," whose cluttered living spaces pose health problems but also are symptomatic of mental illness. The agency is considering whether to move to engage the mental health community in cases like the latter. It is also considering how the Healthy Homes community should help clients deal with environmental insults such as lead, which affect development across the lifespan starting before birth. What types of testing and measuring should be done to address the worst indoor environmental issues?

\subsection{WEATHERIZATION TRAINING}

The Opportunity Council has been offering weatherization training for several decades (See Figure 8.5). In the 1990s, the OC and the Washington State Department of Commerce developed a peer circuit-rider training program in which trainers from agencies with particular expertise traveled around to other agencies in the Pacific Northwest to offer various weatherization-related classes. The peer circuit-rider system is still utilized today. In addition, the OC operates the BPC and has two affiliate training sites located in Spokane and Olympia. The BPC in Bellingham is a state-of-the-art weatherization training facility (See Figure 8.6) financed largely through an ARRA-period grant; the BPC offers hands-on

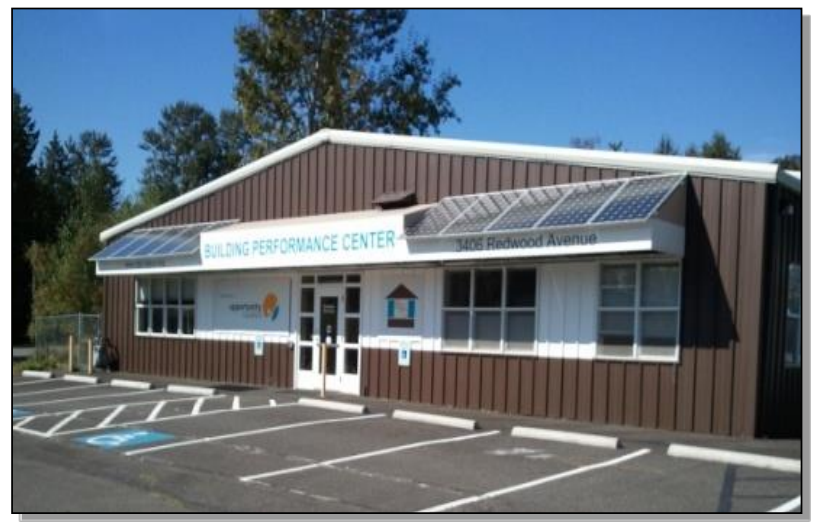

Fig. 8.5. Building Performance Center, the OC's weatherization training facility

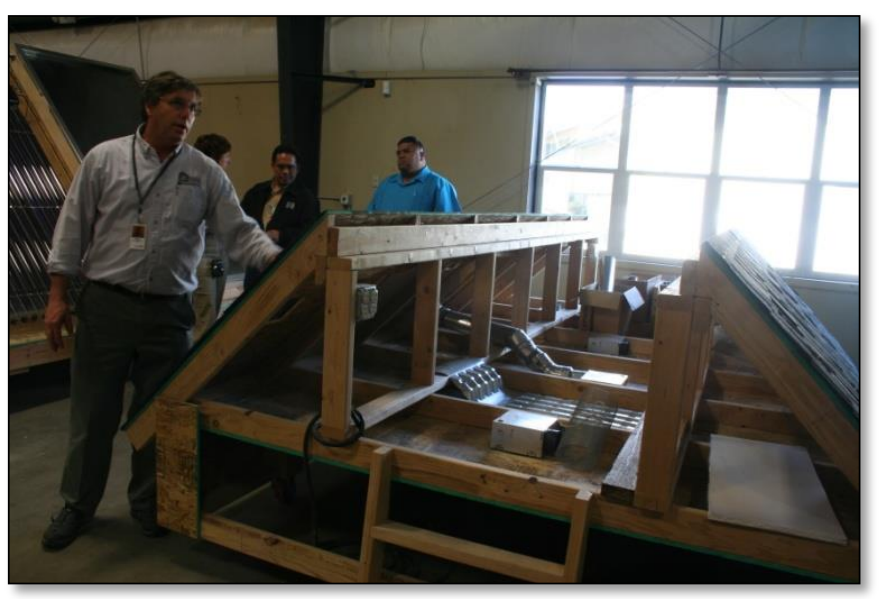

Fig. 8.6. Building Performance Center, the OC's weatherization training facility

learning opportunities as well as classroom instruction in insulation, air sealing, combustion safety, leadsafe weatherization, energy auditing, Healthy Homes measures, and blower door and pressure diagnostics, with certifications in lead-safe renovation and repair, OSHA-approved worker safety and BPI certifications (Building Analyst, Envelope Professional, and Heating System Specialist). There are three 
instructional tracks: Installer 1 and 2 and a third track that focuses on mobile homes. Classes run from one to four days.

Most of the contractors and assessors attending BPC training come from the state of Washington, although participants also come from Alaska and other Pacific Northwest states. The BPC receives 50 percent of its funding from the state of Washington. It also charges a fee for classes offered to privatesector participants and regularly rents out equipment and its facility. The BPC is working to develop and market training services to contractors in British Columbia, Native American tribes, and utility contractors in the region.

\subsection{ARRA PERIOD}

The ARRA period allowed the OC to weatherize more homes than in the past, and direct positive impacts on local employment were noticeable, the ARRA ramp-up period was stressful and the ramp-down period was painful (the OC's experience was particularly compressed, as it was required by the state to spend all its ARRA funds by June 2011). The agency believes that a more steady flow of funding over a longer period of time would have been preferable.

\section{Davis-Bacon Act}

Like many other agencies, the OC dealt with the Davis-Bacon provisions of the ARRA period by hiring a new person to keep track of everything. However, the OC's experience was somewhat more complicated because Washington State required a separate schedule for prevailing wages, so following both state and federal wage schedules was, according to OC, a "nightmare."

\subsection{LOOKING TO THE FUTURE}

\section{Funding Levels}

The Opportunity Council favors retaining the $\$ 6,500$ average cost-per-weatherized-home target, especially since they have limited leveraged funds to weave in with DOE funds. OC's weatherization jobs are averaging $\$ 9000$, which encompasses cost-effective weatherization measures as well as funds for health and safety measures and includes multifamily as well as single-family structures. The OC believes that if the average were to go back to $\$ 2,500$, the pre-ARRA level, cost effective work would be the only measures that could be completed.

\section{Regulatory Compliance}

The OC believes that ASHRAE 62.2 standards (Ventilation and Acceptable Indoor Air Quality in LowRise Residential Buildings) will be fairly easy to implement in Washington. OC has already been putting fans in homes when necessary as part of the Weatherization Plus Health program. In addition, the BPC is offering trainings on how to successfully implement ASHRAE 62.2 requirements.

Some weatherization measures offer energy savings and health-and safety-benefits, not one or the other (e.g. lead removal around old windows when installing new ones, or replacing a furnace with a cracked heat exchanger). The $\mathrm{OC}$ would like the DOE rules to recognize that fact and to establish a maximum expenditure for established SIR energy efficiency measures but then to allow additional funds to be used for health-and-safety repairs.

The OC believes it would be wise to allow more flexibility in federal funding for whole-house repair work. This would avoid the need for many deferrals that must be made because of poor building conditions. If HUD, HSS (LIHEAP), CDBG and others, for example, were to pool resources and create a 
fund for health, safety and repair work similar to the DOE fund for energy-efficiency improvementsfunding that was easily accessible to local weatherization organizations like the OC could do more in more homes, as conditions warrant, and significantly reduce the number of deferrals.

In addition, the network created would allow weatherization programs around the country to leverage each other's expertise, with the end result of helping low-income Americans live in healthy, safe, durable, energy-efficient, affordable, and comfortable homes.

Despite the funding hike from ARRA, thousands of homes still need weatherization and major repairs in OC's counties. Further issues will be presented by an expected rise in the number of elderly clients and by the severe effects of the economic crisis on employment levels in the area; unemployment has been very hard on the community fabric and families in the area, raising numbers of income-eligible residents in the area.

\subsection{PROFILES}

\subsection{Energy Education Proves Its Value Even In a Deferred Home}

The OC's education specialist was called in to visit a family identified for the weatherization program. The education specialist visited the home to conduct a pre-audit and to talk with the family about their household habits and concerns (See Figure 8.7).

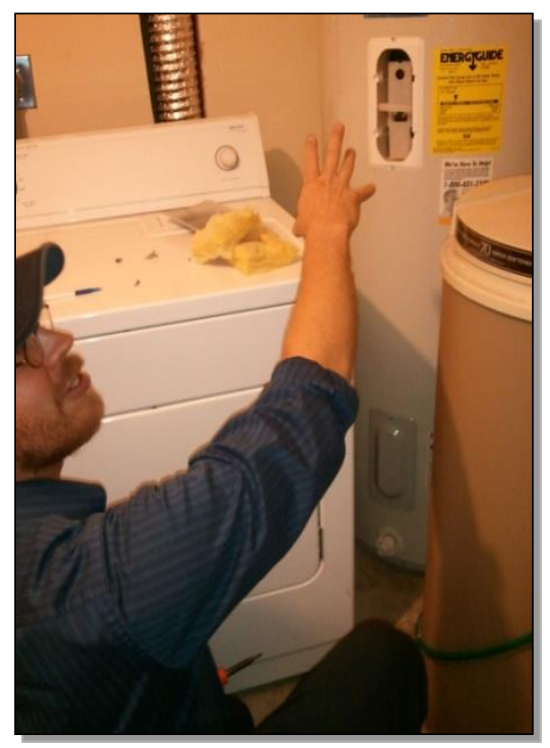

Fig. 8.7. Education Specialist discussing energy efficiency options

The education specialist tested appliances, checked the water heater temperature setting, checked the furnace filters, inspected the home for air sealing opportunities, and checked for smoke and CO detectors. Unfortunately, the extent of the problems, including roof leaks and hazardous electrical issues, made it necessary to defer the project from participation in the weatherization program until a number of significant repairs could be completed. At the time of the visit the OC did not have home repair funds available. 
Despite the deferral, the family did receive the benefit of conservation education and a number of energy saving suggestions from Eric, one of the education specialists. The top three measures the family promised to adopt were utilizing "zone heating" technique (sealing off a room to make the heated space smaller during the winter months), upgrading or removing an old freezer, and taking shorter showers.

The education specialist also reduced the water-heater temperature setting from $147^{\circ} \mathrm{F}$ to $120^{\circ} \mathrm{F}$ and cleaned the furnace filters. If the family chose not to upgrade and or remove the old freezer, he suggested emptying out the old freezer when stocks got low, using the fridge's freezer space, and turning the freestanding freezer off.

Although the family was disappointed not to be getting weatherization, they appreciated the information the energy specialist provided and the interest in helping them conserve energy even without a weatherization (See Figure 8.8).

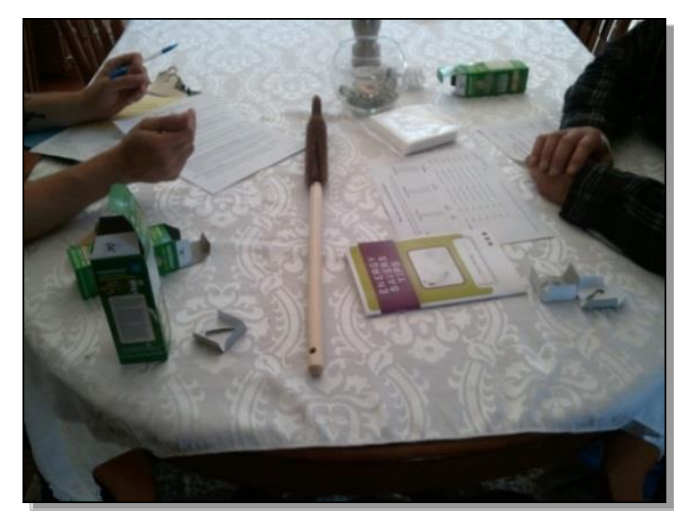

Fig. 8.8. Kitchen table wrap-up with three recommended energy saving actions

\subsection{Weatherization Plus Health Home}

The case study team also visited a home that received Weatherization Plus Health measures. The household consisted of a young mother with her own mother and a young daughter in a single-family home; the young daughter suffered from asthma. Among the various measures installed and work performed, the OC crew separated the venting for the furnace and the hot-water system, installed a Whisper fan (See Figure 8.9) in the main bathroom (the fan runs continuously at 30-70 cfm and can be boosted to $80 \mathrm{cfm}$ ) and replaced some of the carpeting with hard-surfaced flooring to reduce asthma triggers (See Figure 8.10). The OC also helped the family minimize exposure to dust mites (with pillow and mattress covers), mold, and fumes in the home from cleaning products (by providing a non-toxic cleaning kit and directions for making non-toxic cleaners). A HEPA vacuum cleaner was also provided. The grandmother reported to the case study team that all the family members were suffering fewer headaches and that their natural-gas bill had dropped from $\$ 300$ to $\$ 150$ per month. 

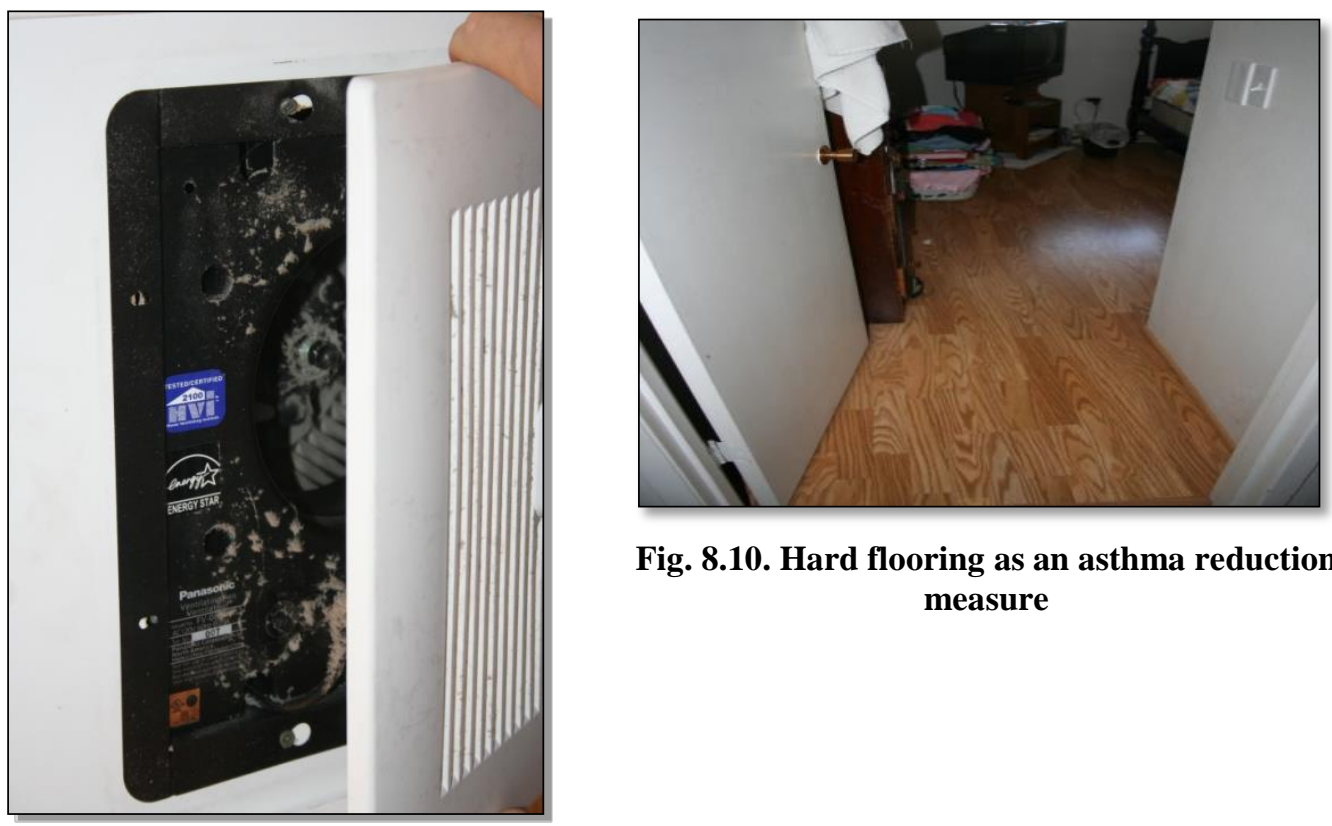

Fig. 8.10. Hard flooring as an asthma reduction measure

Fig. 8.9. Panasonic Whisper bathroom ventilation fan 


\section{CENTRAL VERMONT COMMUNITY ACTION COUNCIL}

\section{$9.1 \quad$ INTRODUCTION}

Incorporated in 1965, Central Vermont Community Action Council (CVCAC) operates as a 501(c) (3) non-profit organization serving central Vermont. The Weatherization Assistance Program (WAP) operated by CVCAC adheres to the shared mission of Community Action Councils and to the local mission of its agency (See Figure 9.1) by working to alleviate the suffering caused by energy insecurity. People are considered to be energy insecure if a large percentage of their household income goes toward energy for their home ${ }^{15}$.

Under the agency's home performance umbrella, WAP serves to provide increased energy efficient, affordable and healthy housing to households of low socio-economic status (SES) residing within an economically distressed community. CVCAC's WAP provides direct weatherization services through energy audits and measures targeting reductions in home energy loss and consumption. Furthermore, the Program is committed to offering households capacity building education, which serves to empower occupants with an increased ability to make energy smart decisions. These two components - weatherization measures and education - aim to alleviate the effects of fuel poverty and poor indoor environmental quality, while offering households the opportunity to redirect scarce resources previously funneled into electricity, heat, and comfort.

The success of this agency is attributed to the technical proficiency of its staff, respect and advocacy for the target population it serves, its efficient delivery of services, healthy amounts of risk-taking while piloting new ideas and innovations, and its commitment to seeking partnerships and leveraging resources.

\subsection{OVERVIEW OF CVCAC'S PROGRAMS AND SERVICES}

Community Action Councils (CACs) were first established during the Johnson administration's War on Poverty as part of a strategy to combat rising poverty rates. CACs agencies employ a comprehensive and multi-component approach to addressing the roots and tangles of complex issues associated with poverty. Like other CACs, the Central Vermont agency is committed to combating poverty-related risk factors and symptoms unique to their community. According to CVCAC's Weatherization Program Manager, Paul Zabriskie, CVCAC is responsible for weatherizing a two thousand square mile service territory in the Green Mountains. The 2010 US Census reports that 19.7 percent of the approximate 9,000 persons residing in the Barre (city) area live below the poverty line. This compares to its Washington County rate of 10.5 percent. Vermont as a whole has a

${ }^{15}$ CVCAC uses the term energy insecurity to guide its mission, but has no set definition on what percent of income used to heat a home qualifies as energy insecure. 
poverty rate of 11.1 percent. CVCAC remains critical for providing both direct services and capacitybuilding programs to the area, as evidenced by its operating the second busiest food shelf in the state. CVCAC operationalizes the CAC's general mission, as well as its local mission through a range of services and programs (Table 9.1).

Table 9.1. Overview of CVCAC Programs and Services

\begin{tabular}{|c|c|c|}
\hline PROGRAM & SERVICES & $\begin{array}{c}\text { ANNUAL IMPACT: OVER 18,000 PEOPLE } \\
\text { SERVED } \\
\end{array}$ \\
\hline Support Services & $\begin{array}{r}\text { Heating and Utility Assistance; Food } \\
\text { and Nutrition; Tax Assistance; } \\
\text { Children's Hour; Housing Counseling; } \\
\text { Service Coordination }\end{array}$ & $\begin{array}{l}\qquad 6,000 \text { people access emergency food } \\
\text { - Over 2,000 households receive home heating } \\
\text { fuel } \\
\text { - More than } 600 \text { families get help to find and } \\
\text { keep safe, secure housing }\end{array}$ \\
\hline Head Start & $\begin{array}{r}\text { Head Start and Early Head Start; Family } \\
\text { Literacy Center; Vermont Family } \\
\text { Matters; HomeStart }\end{array}$ & $\begin{array}{r}\text { - } 500 \text { children access early education and } \\
\text { developmental services through Head Start } \\
\text { and Early Head Start }\end{array}$ \\
\hline $\begin{array}{l}\text { Community } \\
\text { Economic } \\
\text { Development }\end{array}$ & $\begin{array}{r}\text { Microbusiness Development; VT } \\
\text { Women's Business Center; Credit and } \\
\text { Financing; Individual Development } \\
\text { Accounts; Child Care Food Program; } \\
\text { Community Capital of Vermont }\end{array}$ & $\begin{array}{l}\text { - } 45 \text { businesses start or grow and provide } 30 \text { jobs } \\
\text { for their owners and others } \\
\text { - 1,500 children are fed nutritious meals while in } \\
\text { child care }\end{array}$ \\
\hline Weatherization & $\begin{array}{r}\text { No-Cost Weatherization; EnergySmart } \\
\text { of Vermont; Button-Up Vermont; } \\
\text { Weatherization Skillshop }\end{array}$ & $\begin{array}{l}\bullet 350 \text { homes are weatherized, making them } \\
\text { warmer and more energy efficient } \\
\text { - } 581 \text { completed WAP units during the American } \\
\text { Recovery and Reinvestment Act (ARRA) } \\
\text { Period (Program Years 2009-2011) } \\
\text { - } 155 \text { installations of solar technology on WAP- } \\
\text { eligible households through SERC funds } \\
\text { - Managed energy coaching in } 4000 \text { units } \\
\text { providing consumer energy education to } \\
\text { households across the state with DOE SERC } \\
\text { funds }\end{array}$ \\
\hline $\begin{array}{l}\text { Workforce } \\
\text { Development }\end{array}$ & Vermont Green & $\begin{array}{r}\text { - Over 2,000 Vermonters trained in green jobs } \\
\text { across the state }\end{array}$ \\
\hline Transportation & Vermont Car Coach Project & $\begin{array}{l}\text { - } 200 \text { people secure reliable transportation to } \\
\text { secure and maintain employment }\end{array}$ \\
\hline
\end{tabular}




\subsection{CVCAC AND THE WEATHERIZATION ASSISTANCE PROGRAM}

\section{Weatherization Philosophy}

Weatherization Program Manager, Paul Zabriskie (See Figure 9.2) believes technical proficiency provides the foundation for the agency's home energy programs. Adequate training in the areas of building science and technical application of weatherization measures are an integral first step before seeking leveraging funds and partnerships for piloting new ideas and innovation. This intended philosophy is substantiated by independent sources. During the process for selecting WAP Subgrantee for this case study task, CVCAC was recommended for their technical application of weatherization, its efficiency in service delivery, its use of equipment and materials, the quality of its installations, the organization of its crews, and its communication and problem solving while on the job site. It is further substantiated by their long list of leveraged resources, partnerships, and sustainable planning initiatives.

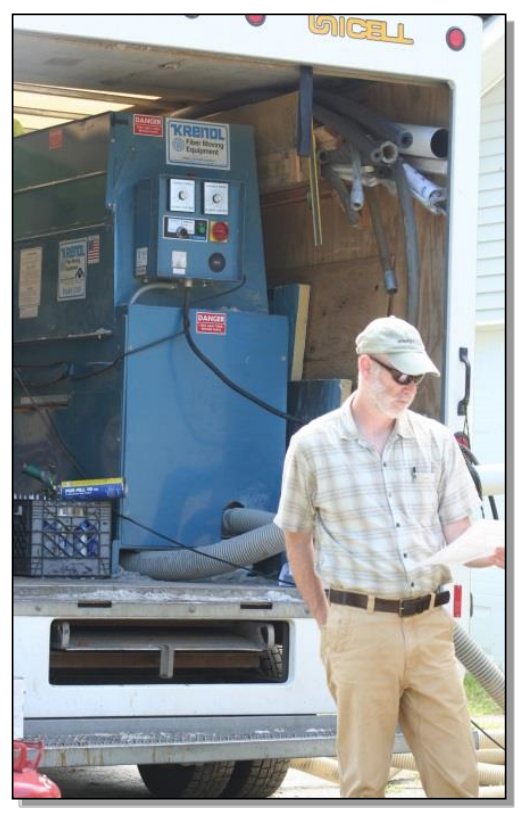

"Success in WAP is about retaining quality crew people, and that means keeping them happy, healthy, and well paid."

Paul Zabriskie CVCAC WAP Program Director

Fig. 9.2. Paul Zabriskie, CVCAC WAP Director

Zabriskie's approach to keeping a cohesive team involves "retaining quality crew people and that means keeping them happy, healthy, and well paid," he says. "If you torture your staff, they won't stay." Zabriskie has a multi-faceted approach to improving working conditions. Crews know that he wants them to try new materials or equipment if it will make their job easier while still achieving their goals. Examples are their use of two-part foam, which can be used to insulate basement band joist areas more quickly and effectively than other air sealing and insulation materials can. The product requires a fireresistant coating to be painted over it, and it requires more personal protective equipment, but it makes the job easier for the crews. 
Crews have also experimented with many different types of battery-powered hand tools, seeking those that perform the best, have long battery lives, and can withstand the daily punishment. Zabriskie considers his crews experts in which products work best for a given job.

The Executive Director (ED), Hal Cohen, recruited Paul for the job. Cohen allows programs to have their own identities within the agency and community. In return, Zabriskie elevates the ED in the eyes of the field staff. He feels it is important that they respect the Director and to let them know he appreciates their dedicated effort in the field.

\section{Weatherization Delivery}

CVCAC implements a crew-based weatherization model, subcontracting work out only for specialized measures. Zabriskie reports that all weatherization work under WAP had initially been subbed out to contracting agencies. However, CVCAC found that these agencies did not always treat families with the same dignity that they expect of their in-house crew members.

Two auditors and five crews work for the Program, putting in four 10-hour days per week. Zabriskie provides argument points for a 4/10 work week, which fall into two primary buckets; cost and best interest of the staff. The following multi-targeted points offer support for this management decision:

- 3 day weekends assist with the physical and mental rejuvenation of crew members

- Crew members are better able to work second jobs over the weekend if desired (as long as they are not in competition with CVCAC's fee-for-service energy auditing company, EnergySmart)

- Cuts down on costs associated with travel time. The crews meet at 7 a.m., load the trucks from the warehouse, and head out into the field. The warehouse is stocked with what they can store: solar hot air panels, high efficiency bathroom fans, 2-part foam, and specialized air sealing products and equipment. Zabriskie reports CVCAC partners with local lumber yards and hardware stores for materials in order to support local businesses.

Auditors conduct the initial home diagnostic energy audit and the model the building to analyze investment options. The scope of work is based on the savings-to-investment ratios provided by DOE's NEAT auditing tool.

Zabriskie pays staff just above what the other agencies in Vermont pay. Being in the county with the State Offices, the agency also tends to lose staff to open positions at the State Office. The State monitors tend to look for similar work quality from the other agencies based on their experience working for CVCAC.

\section{Service Territory}

CVCAC's central office is located in Barre, Vermont. The CVCAC service territory includes Lamoille, Orange, and Washington counties and nine communities adjacent to these counties, for a total of 56 towns (See Figure 9.3). As a result of the geographic distance covered by the CVCAC weatherization crews, and the various state seasons, services to some eligible households may be delayed until after the winter and the Green Mountain "mud” season are over. 


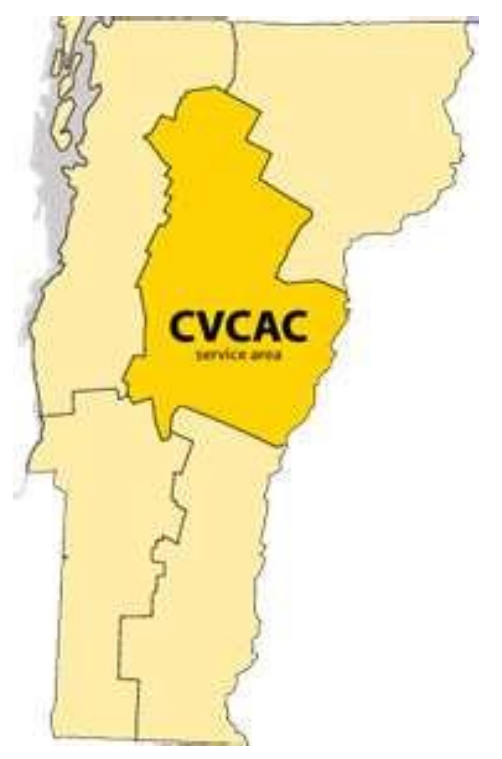

Fig. 9.3. CVCAC Service Territory

In addition to the designated service territory assigned to CVCAC by the state, the energy efficiency services department of the agency delivers both regional and state-wide building performance initiatives. CVCAC produces a series of energy conservation workshops called ButtonUp Vermont, and operates the state's leading Home Performance with Energy Star renovation company as a social enterprise branded EnergySmart of Vermont. CVCAC also administers the Vermont Fuel Efficiency Partnership (VFEP), a collaborative of the Vermont WAPs and regional housing partners that provides technical support and financial incentives - using Regional Greenhouse Gas Initiative (RGGI) carbon auction proceeds - for deep energy retrofits of multi-family buildings.

\section{Training}

CVCAC is committed to staff training, believing this is "best practice" for staff development and high performance. Both formal training and on-the-job coaching, or mentoring, are highly valued. After a sixmonth probation period, new staff members receive extensive training, both locally and at national and regional conferences, over the an 18 month period. In addition, other classes offer information on building science, current innovations, and recognized best practices. Training bolsters the confidence and pride of new staff members and it gives them "a reason to swagger." The path for advancement within the agency is clear, and both training and work experience are important factors for promotion. Staff is always crosstrained and moved around as needed for efficiency, and to ensure the right people are placed in the right positions.

In the field, crews and crew leaders are expected to problem-solve together. Crew leaders can phone the office for assistance with complex issues, but are empowered through Zabriskie's participative and delegative leadership techniques to develop solutions as a team in the field. Zabriskie believes this commitment to training and crew empowerment promotes technical proficiency and a quality program.

The CVCAC WAP team applies the same philosophy adopted for WAP when developing ideas for new programs. The observed need for and commitment to training led to a proposal for grant funding from the Department of Labor. As a result, CVCAC now operates a mobile training lab: WAP staff travel across the state training other weatherization professionals as well as Vermont citizens who are interested in doit-yourself weatherization. At these public demonstrations, CVCAC shows professionals and citizens 
both "what" should be done and "how" it should be done to best improve a home's energy efficiency. Their partnership with Vermont's efficiency utility company, Efficiency Vermont has provided this opportunity for outreach into the private sector. In addition to leveraging training initiatives, Efficiency Vermont funds other home energy projects and programs delivered through CVCAC (See Table 9.2).

\section{Adopting a Whole House Approach within Whole Communities}

Implementing a "whole-house" or "whole-building" approach to weatherization has been widely adopted by the weatherization community. Whole-house weatherization involves the use of building science to assess the home as an energy consuming system and to identify the best package of measures for the reduction of energy usage. The scope of work for each home includes these elements:

- whole-house energy assessment

- whole-house health-and-safety assessment

- household energy education

CVCAC has adopted this philosophy for the technical application of energy assessments and scopes of work. The Program has also integrated health and safety assessments, and energy education components into this model. Being a CAC, the agency understands the importance of inter-linking social and building science through multi-disciplinary programs. These multi-component programs target multiple problems or risk factors commonly faced by households of low socio-economic status. To pull these components together generally requires "braiding" or combinations of funds or resources from multiple sources and stakeholders. While the CVCAC WAP staff remains dedicated to the mission of WAP and to the promise of energy and non-energy benefits attributed to weatherization, working with the target population requires addressing issues beyond fuel poverty and indoor environmental quality. Zabriskie and Community Outreach Director Liz Schlegel were asked about other projects or programs they would like to initiate. Zabriskie answered that a smoking cessation program and an HIV/AIDS prevention program for the community would be recommended.

\section{Innovation and the Evolution of CVCAC's Weatherization Program}

Zabriskie describes the organizational culture of the state as having a high tolerance for healthy risk taking. CVCAC's commitment to piloting and evaluating the impact of new and innovative technology guides the agency in determining the value in seeking additional funding to install these technologies on a larger scale, and provides a foundation for securing additional funding. Zabriskie's approach to innovation is a frequent, "Let's pilot that." He is afforded the freedom by Executive Director Cohen, to "put a little funding in to see if it will work." That's how EnergySmart developed. EnergySmart is a program operated by CVCAC built upon weatherization concepts. However, it is a fee-for-service company available to households at all income levels.

Peter Drucker, whom the Wall Street Journal refers to as "the dean of this country's business and management philosophers," states the importance of program mission "review, revision and abandonment."16 Similarly, Paul Zabriskie states the need to be flexible within a project or program and says, "It's okay to change course. Don't be attached to the idea of what should be; allow for course correction." Zabriskie's view is it is healthy to risk a little, because risk allows change. Change, when

\footnotetext{
${ }^{16}$ Peter F. Drucker, Managing the Nonprofit Organization: Principles and Practices (New York: HarperCollins Publishers, Inc., 1990), 5.
} 
supported by management, is the path to learning new things and improving the working process while achieving better results for program recipients.

CVCAC's role in Vermont's Sustainable Energy Resources for Consumers (SERC) Grant

The 2007 Energy and Independence Security Act (EISA) (Title IV Section 411(b)) allows DOE to allocate up to 2 percent of WAP funds for the inclusion of renewable and innovative technologies if the funding for the fiscal year exceeds $\$ 275 \mathrm{M}$. When $\$ 5$ billion was appropriated to WAP during the ARRA era between 2009 and 2011, DOE was able to allocate up to $\$ 100 \mathrm{M}$ for SERC projects across the Program. They opted to award $\$ 90$ million in grant funds across 27 states. Vermont and its five WAP Subgrantees received $\$ 5$ million to conduct community-based social marketing and to install solar hot-air panels (See Figure 9.4) and solar water heating technologies in single-family and multi-family buildings.

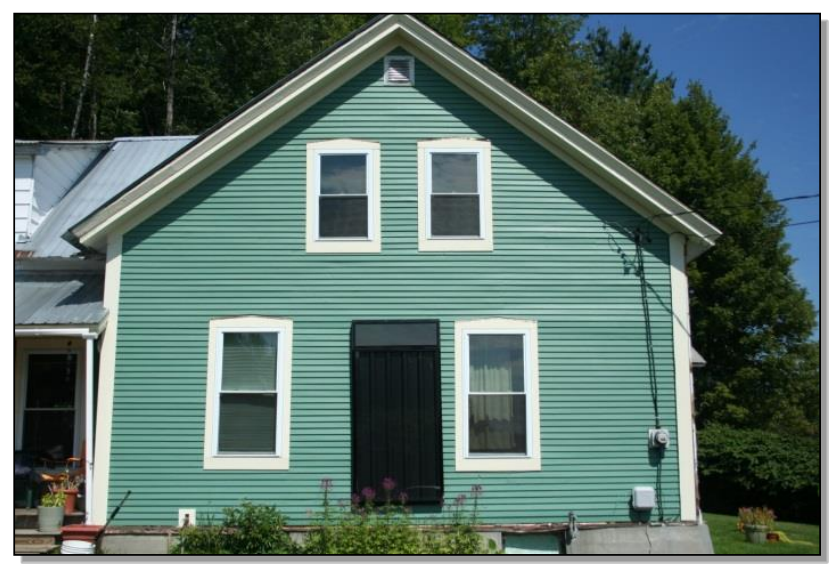

Fig. 9.4. Solar Hot Air Panel (between two first floor windows)

The organizational culture at both Grantee and Subgrantee levels encourages healthy amounts of risk taking and flexibility in trying new concepts and tools related to weatherization. Prior to the DOE SERC announcement and request for proposals, the CVCAC had already been investigating the effectiveness of solar hot-air panels for Vermont's climate and housing stock. They installed a solar hot air panel on the mobile home of a staff member. With encouraging energy savings results in hand and a desire to pilot more, the agency approached Jane's Trust, a Boston-based foundation, and was awarded enough funds to equip 10 more units. It was from this modest beginning that CVCAC's project proposal for the SERC grant was drafted.

In addition to funds for the solar technologies, the state proposed and was awarded SERC funds to implement Community Based Social Marketing (CBSM), in the form of energy-efficiency coaching for WAP-eligible households (Figure 9.5). To deliver CBSM, the agency created new positions for both leadership and service delivery staff, coaching members of over 3,000 households who were receiving WAP. Topics covered by the efficiency coaches included thermostat setback, moisture control, heating system maintenance, and electrical use. The goal of CBSM is to meet members of the household where they are to learn how they consume energy in their home; identify, select, and strategize around actions proven to reduce energy consumption; and address barriers preventing household members from successfully implementing change. For Zabriskie, the point of the CBSM initiative was to find a way to "help folks catch onto the benefits of energy efficiency in the home." Zabriskie envisions incorporating 
popular education tools into the energy education delivered by his staff. The goal is to raise the consciousness of households to achieve persistent change in their energy-consuming behaviors.

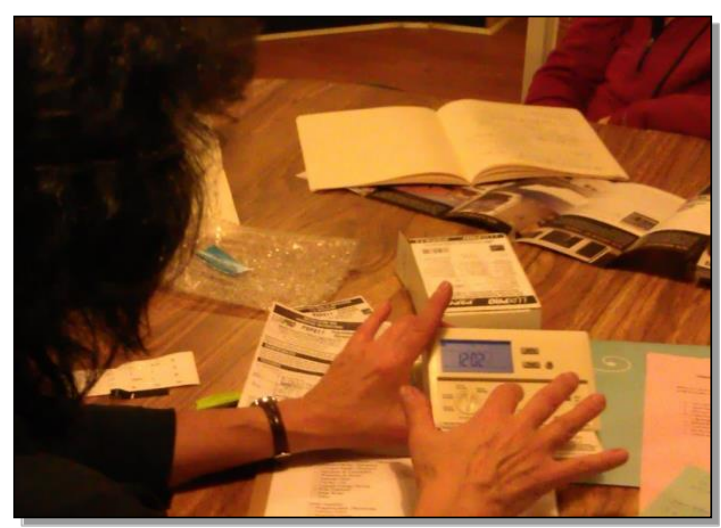

Fig. 9.5. Delivery of CBSM

\section{Site visits}

Brief visits to two work sites showed how the agency's weatherization approach is working in the field. The first site was a mobile home, occupied by a single mother and her 12-year-old son. The home is also utilized as a respite home for foster children and adults requiring care during the day. The head of household reported that she keeps the thermostat at $65^{\circ} \mathrm{F}$ during the winter to save on fuel costs, but the occupants are always cold. The audit revealed a cracked heat exchanger in the furnace and high levels of CO. The Scope of Work included a CO detector, a drier vent, air sealing, insulation, ductwork and a storm window for the bathroom. Concerned for her family's health and safety, yet also concerned about late mortgage payments, she inquired about predicted energy cost savings. Zabriskie replied that although projecting cost savings is not in the work scope, the agency average for energy reduction is between 3035 percent, with a cost savings average ranging from $\$ 400-\$ 500$ annually.

Upon arrival at the site, the crew was already hard at work accessing the ceiling cavity so they could insulate it with blown-in cellulose (Figure 9.6). The crew was cutting in access holes on the ridge that would later be covered with a multi-step patching process. Many crews and contractors would be wary of this method, but by using the proper techniques and materials, the crew could provide a much better insulation job and prevent future leaks. A crew member sealing around the furnace and water heater flue pipes understood the workings of the appliances and the materials needed to be used and was not just air sealing.

At a second job site, two crews had been dispatched to work on a home. The house had been added on to over the years creating challenges to properly insulating and air sealing the building. The crew leaders had worked out a plan of attack and the crews were air sealing some difficult to access building cavities and blowing the slopes in one of the attics by accessing them from the fascia (Figure 9.7). During this process the crew chief rescued some baby squirrels that had been nesting in the attic (Figure 9.8). A walk around with one of the crew leaders showed they had recognized the problem areas in the house and had come up with a work plan to solve the problems. In both cases, the crews appeared to be knowledgeable and efficient in getting their work done. The work will also involve the installation of a solar hot air panel in the main living area. 


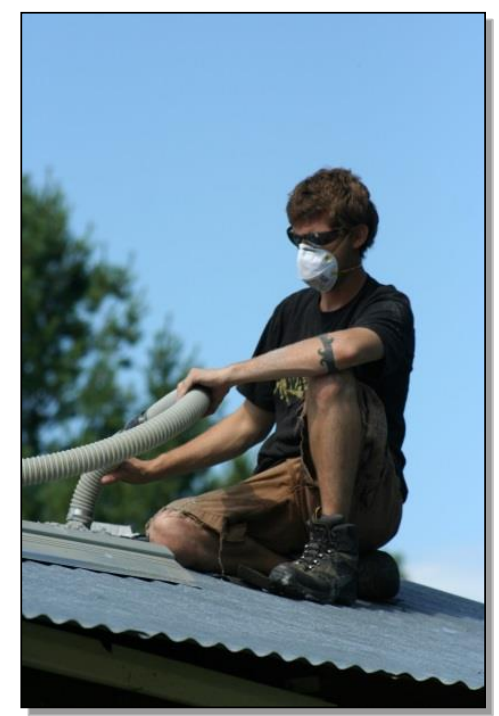

Fig. 9.6. Blown-in Cellulose Insulation

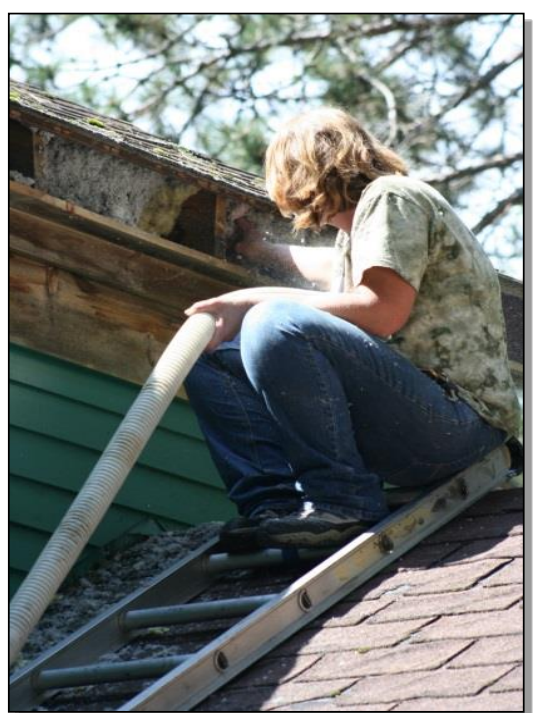

Fig. 9.7. Blowing insulation into access holes cut into ridge

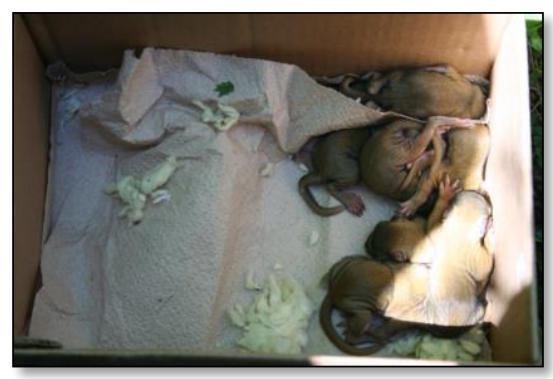

Fig. 9.8. Crew chief finds baby squirrels upon accessing the attic

The home was occupied by two adults and two small children. The family reported intentions to heat the home with wood during the coming winter and reported extended family support with the gift of a new wood stove. They reported having been in the home the previous winter and stated the home was so cold they could not sleep in the upstairs bedrooms. They had all slept on the floor of the living room huddled around the old wood stove. The female occupant was in her third trimester of pregnancy. They then heard about CVCAC's weatherization program through a friend who works in the home energy retrofit field. The family's three primary reasons for applying for WAP services were comfort, cost savings, and environmental conservation.

\section{Bulk Fuel, Weatherization, and Energy Savings Potential}

It is easy to have high expectations for CVCAC's weatherization program. Other research conducted as part of the retrospective evaluation of WAP has found that weatherized homes heated with bulk fuels (e.g., fuel oil, propane) located in cold or very cold climates save more money than homes heated with other fuels (e.g., natural gas) located in other climate zones because these bulk fuels costs more.. Investments in energy efficiency measures in these homes are also considerably more cost-effective. It happens that CVCAC is located in the very cold climate zone and the majority of households served by CVCAC heat their homes with bulk fuels $-50 \%$ use fuel oil, $26 \%$ use propane or kerosene. To exceed 
expectations, CVCAC combines the technical proficiency of its staff with effective management techniques, effective targeted marketing and community outreach, a commitment to occupant energy education and advocacy, and a state cultural norm for energy efficiency and environmental stewardship. CVCAC is an ideal vehicle for meeting WAP energy savings goals.

\section{Leveraging Portfolio}

CVCAC has been successful in leveraging additional resources to deal with problems typical in lowincome housing that are caused by deferred maintenance, such as roof repairs, knob and tube wiring, and other building repairs that allow them to weatherize a building that the agency would otherwise be unable to weatherize.

CVCAC seeks and braids leveraged funding for their energy projects and for the piloting of new projects and technologies (See Table 2.0). Like other CACs in the state, CVCAC leverages WAP dollars with funds from other federal and non-federal sources to support its weatherization efforts. The state's energy efficiency utility (Efficiency Vermont) as well as state departments interested in targeting consumer education have contributed. The agency has also secured funding from non-DOE federal departments, such as the Department of Labor, which funded CVCAC's mobile training lab for training staff from other weatherization programs in the state.

Vermont's REGGI funds Weatherization Skillshops, a program that educates the general public in do-ityourself weatherization and actions related to reduced energy consumption. Components of the workshops include weatherization measures and home energy conservation related to home energy usage.

\subsection{SUSTAINABILITY PLANNING}

CVCAC leadership recognizes the need to diversify to prevent the agency from becoming solely reliant on DOE's weatherization formula allocation to support their energy conservation programs. This diversification initiative involves a marketing position, emphasis on piloting new technologies, and strategic planning for the future. CVCAC made efforts to reduce this dependency on DOE WAP dollars by hiring two development professionals to "troll" for new funding opportunities, and by hiring one fulltime employee charged with managing the agency's marketing campaign and outreach within the community, Liz Schlegel. Schlegel spends the majority of her time marketing the energy programs for CVCAC, which means knowing the potential customers. A quarter of her time is also spent on education and advocacy, giving the agency additional insight into the customer base.

In addition to its WAP work, CVCAC does fee-for-service work through its EnergySmart program. EnergySmart is a Home Performance with Energy Star program working under sponsor, Efficiency Vermont. This program allows the agency to complete audits and weatherization work with households of moderate-high socio-economic status within the residential sector of Vermont. The CVCAC weatherization umbrella shelters four separate energy efficiency programs; each building upon the strengths of the others while capturing different funding opportunities targeting and serving diverse customer bases. CVCAC intends to continue to strategize how best to modify its successful and effective weatherization model for applicability across all socio-economic status households.

\section{Current CVCAC Events Focused on the Future}

At the time of this case-study report, Vermont was addressing WAP Program Year 2012 funding news for their state. With the Program having been ramped up during the ARRA period and zero dollars allocated by DOE, the state WAP network appealed to alternate sources for funding. Fortuitously for Vermont's WAP programs, a merger of the two largest utility companies in the state benefited ratepayers with \$21 
million which were then designated for energy efficiency and weatherization. The controversial decision to designate these funds for this purpose led to heated debate among lobbyists and in the legislature. Schlegel, who had been hired for a diverse skill set including successful advocacy experience, joined Zabriskie and others in the WAP community in a concerted effort to successfully secure weatherization funds resulting from the merger.

Table 9.2. CVCAC Home Energy Programs and Funding Sources

\begin{tabular}{|c|c|c|}
\hline $\begin{array}{l}\text { CVCAC Home Energy Projects } \\
\text { and Programs }\end{array}$ & CVCAC Program Description & Funding Source(s) \\
\hline $\begin{array}{c}\text { Weatherization Assistance } \\
\text { Program }\end{array}$ & $\begin{array}{r}\text { "CVCAC provides weatherization } \\
\text { services free of charge to central } \\
\text { Vermonters who meet income and } \\
\text { other qualifications. Trained } \\
\text { professionals will review the } \\
\text { problem areas in your home and } \\
\text { identify the most cost-effective steps } \\
\text { that can be taken to increase comfort, } \\
\text { reduce heat loss, and ensure } \\
\text { safety." }\end{array}$ & $\begin{array}{l}\text { US Department of Energy (DOE); } \\
\text { The Office of Energy } \\
\text { Efficiency and Renewable } \\
\text { Energy (EERE); } \\
\text { Weatherization and } \\
\text { Intergovernmental } \\
\text { Program (OWIP) }\end{array}$ \\
\hline $\begin{array}{l}\text { Sustainable Energy Resources for } \\
\text { Consumers (SERC) Grants }\end{array}$ & $\begin{array}{r}\text { "Vermont's five local } \\
\text { Weatherization agencies will } \\
\text { collaborate on a statewide effort to: } \\
\text { a) support long-term behavioral } \\
\text { change through the use of energy } \\
\text { efficiency coaches in the low-income } \\
\text { community; b) extend efficiency } \\
\text { savings to low-income families } \\
\text { through the use of solar thermal and } \\
\text { solar hot-water technologies; and c) } \\
\text { use bulk-buying strategies and } \\
\text { cooperative partnerships in buying } \\
\text { solar technologies to lower costs of } \\
\text { materials and extend the grant } \\
\text { reach." }\end{array}$ & $\begin{array}{l}\text { US Department of Energy (DOE); } \\
\text { The Office of Energy } \\
\text { Efficiency and Renewable } \\
\text { Energy (EERE); } \\
\text { Weatherization and } \\
\text { Intergovernmental } \\
\text { Program (OWIP) }\end{array}$ \\
\hline energysmart & $\begin{array}{l}\text { "EnergySmart of Vermont is an } \\
\text { energy renovation contracting } \\
\text { company. We help building owners } \\
\text { make their buildings more efficient } \\
\text { and comfortable, and less expensive }\end{array}$ & $\begin{array}{l}\text { Efficiency Vermont } \\
\text { As a Home Performance w Energy } \\
\text { Star sponsor. } \\
\text { Other Partners: the State of VT, } \\
\text { Washington Electric Cooperative, }\end{array}$ \\
\hline
\end{tabular}

${ }^{17} \mathrm{http}: / / \mathrm{www} . \mathrm{cvcac}$. org/index.php?option=com_content\&view=article \&id=128\&Itemid=86

${ }^{18}$ CVCAC SERC grant proposal (Statement of Project Objectives) 


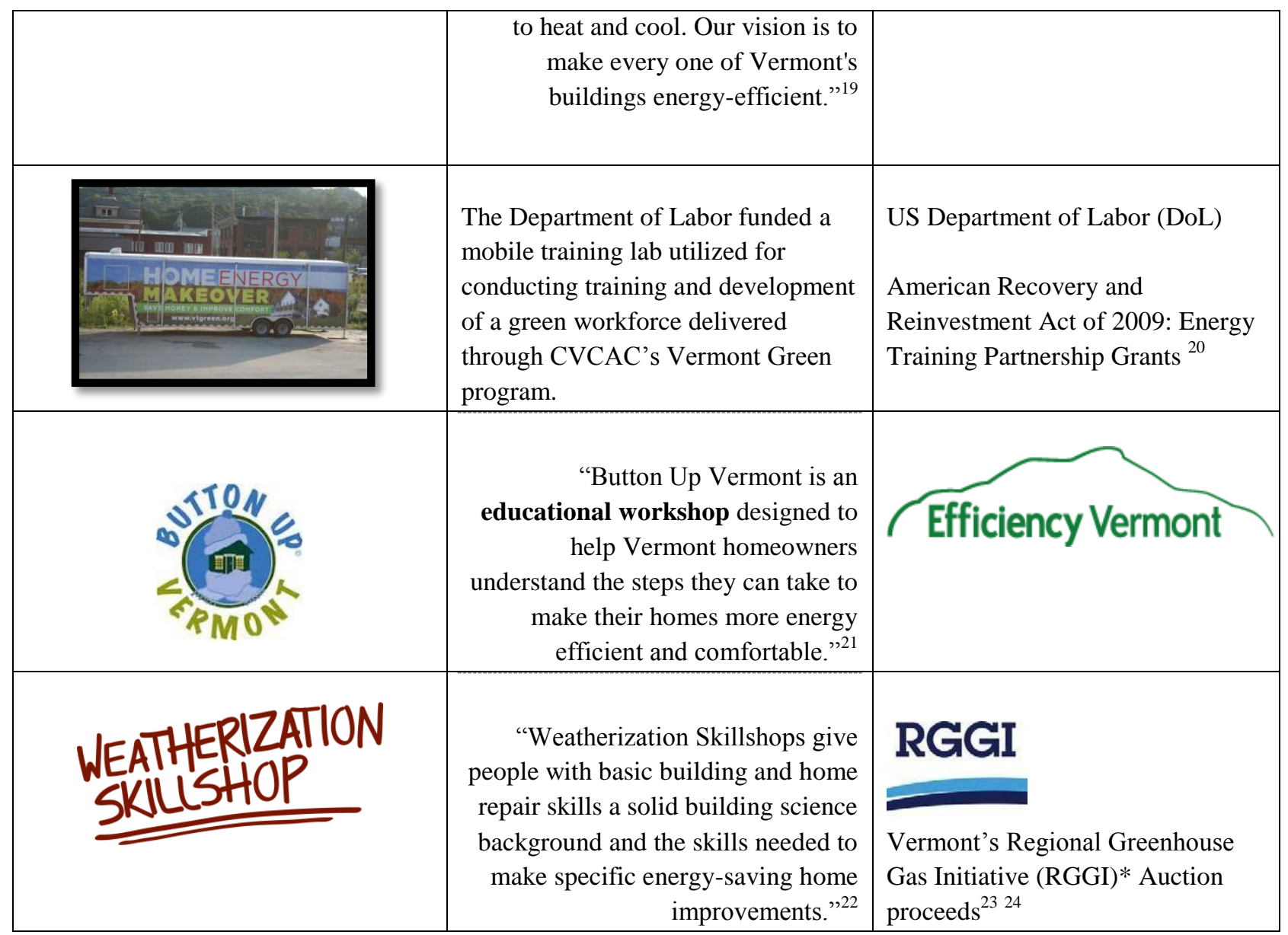

${ }^{19} \mathrm{http}: / /$ www.energysmartvt.com/about-us/mission-vision/

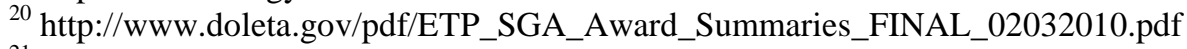

${ }^{21} \mathrm{http}: / /$ buttonupvermont.org/ http://buttonupvermont.org/

${ }^{22} \mathrm{http} / / /$ www.cvcac.org/index.php/weatherization/weatherization-skillshop

${ }^{23} \mathrm{http}: / /$ www.rggi.org/market/co2_auctions/results http://www.rggi.org/market/co2_auctions/results

${ }^{24} \mathrm{http}: / /$ www.rggi.org/rggi_benefits/program_investments/Vermont 


\section{CORPORATION FOR OHIO APPALACHIAN DEVELOPMENT - ATHENS}

\subsection{INTRODUCTION}

The Corporation for Ohio Appalachian Development (COAD) is a 40-year-old nonprofit umbrella organization headquartered in Athens, Ohio. COAD serves 17 community action agencies within 30 counties in the Appalachian region of southeastern Ohio (See Figure 10.1). These counties collectively cover an area that spans four hours of driving time, both north to south and east to west. A Subgrantee of Ohio's low-income weatherization program, COAD distributes weatherization funding to its 17 members by formula.

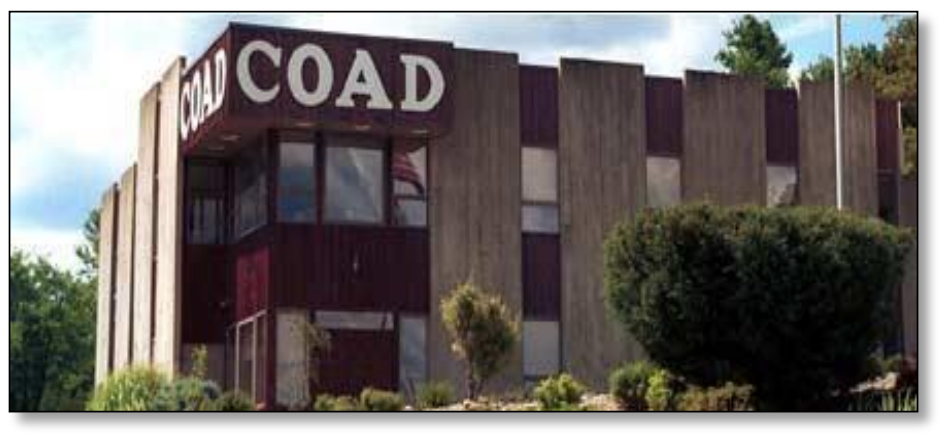

Fig. 10.1. COAD headquarters, Athens, Ohio

COAD provides a range of services in three main categories: early childhood care and education, senior programs, and community development. The community development programs focus on technical and training services in weatherization, energy-efficiency services, and affordable housing and home repair.

The case study team visited COAD early in January of 2012 and met with representatives from its member agencies. The team then conducted site visits with three agencies, Gallia-Meigs Community Action Agency, located in Cheshire, Ohio; Jackson-Vinton Community Action, Inc., located in Wellston, Ohio; and Hocking-Athens-Perry Community Action Agency in Glouster, Ohio, the site of a unique weatherization effort, the village of Murray City (See Profile 1).

\subsection{COAD'S COLLABORATIVE MODEL}

COAD is unique in the national weatherization community in that its 17 member agencies (or "delegates") are autonomous but also highly collaborative. Its philosophy, "One for all and all for one," captures the cooperative's belief that the group of agencies constitutes a large peer-to-peer network of dedicated employees working for a common cause.

COAD was formed in 1971 in recognition that its coverage area in southeast Ohio has more in common with Appalachian West Virginia than it does with the rest of the state. Because of this, the member organizations decided to band together as COAD to present a unified voice to the state of Ohio generally and its weatherization program specifically. Working together has allowed these agencies to compete for funds more effectively and to network creatively with each other, while their independence allows member agencies to innovate and implement different approaches to workforce management. For example, some members work with five 8-hour days; others follow a four 10-hour day schedule. Insights from the different programs are shared during annual meetings and staff board retreats. However, the 
members also compete with each other. For example, COAD has developed a production tracking system with monthly performance ratings; the system has engendered some friendly peer pressure to meet group production norms. COAD claims their agencies are the highest performing agencies in the state due to these aspects of their program delivery model.

\subsection{WEATHERIZATION TRAINING CENTER}

The nationally respected Ohio Weatherization Training Center (OWTC) offers a wide variety of training courses on "building diagnostics, weatherization, heating system services and procedures, industry safety" and other topics. Certification courses for OSHA, BPI and Healthy Homes are also given, with extensive hands-on training to bolster the classroom experience (See Figures 10.2-10.5). The 17 member agencies provide a base of trainees for this center, but over time, COAD has come to be the place where lowincome weatherization staff members throughout the state of Ohio go for training. Having a central training resource helps reduce training costs and increases the quality and consistency of training across the state. COAD boasts that its certification training exceeds BPI requirements.

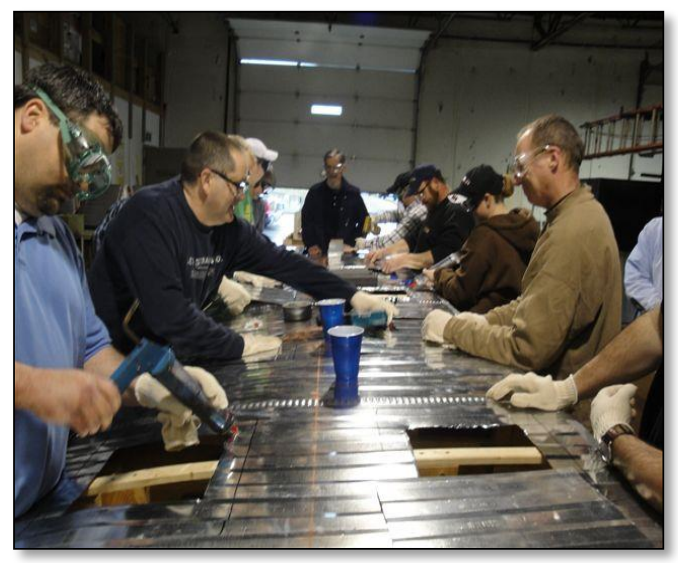

Fig. 10.2. Trainees at Ohio Weatherization Training Center

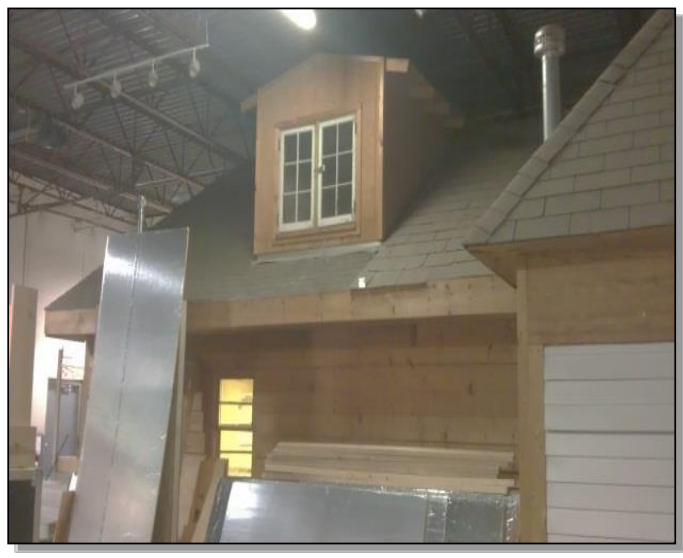

Fig. 10.4. Model home for hands-on training

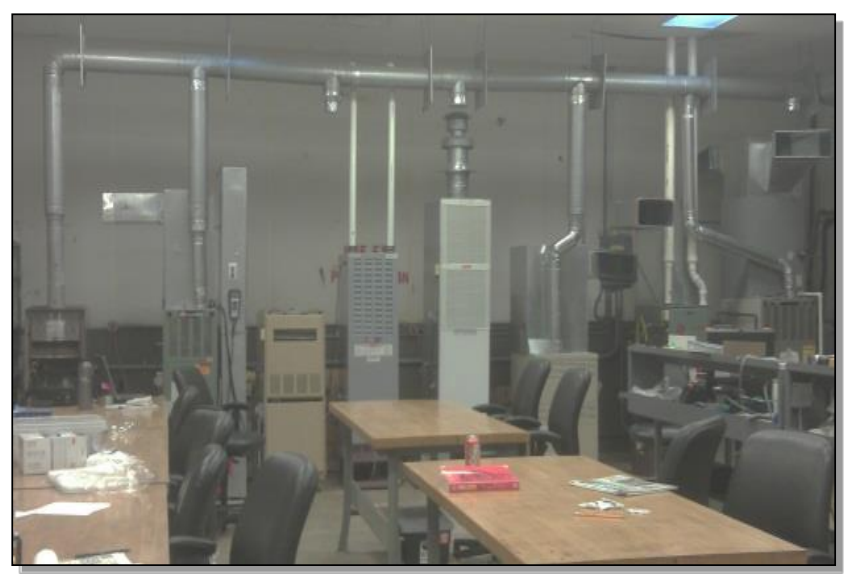

Fig. 10.3. HVAC training center- various heating systems

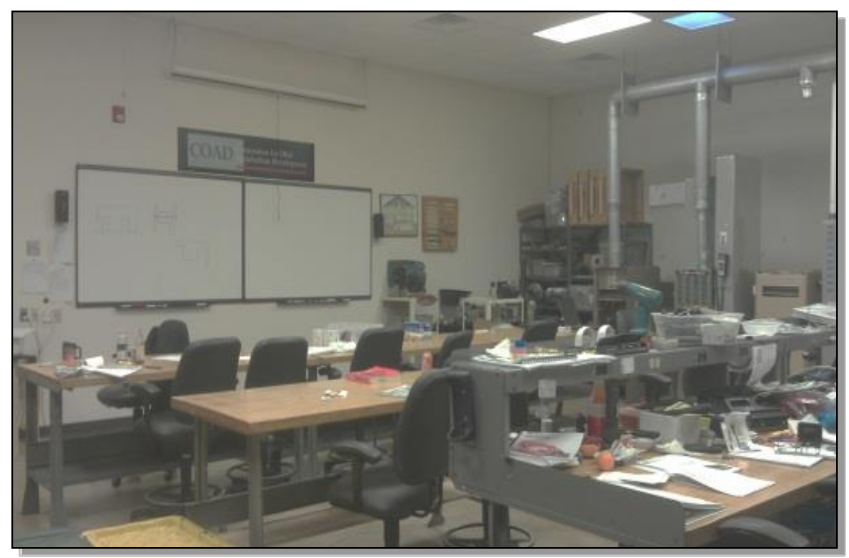

Fig. 10.5. Training center classroom 
In recognition of its program's quality, COAD was recently designated as one of $34 \mathrm{DOE}$ weatherization training centers. To meet increased demand during the ARRA period and to expand its training of contractors, COAD has opened a satellite training facility in Cleveland, Ohio. The 400 new employees hired across the state during the ARRA period were all educated in the COAD training centers.

Because COAD's 17 members serve such a large geographic area, it is not possible to consolidate administrative systems or even warehouses. However, COAD does centrally procure cellulose for insulation and has also utilized ARRA funds to buy new Krendl cellulose machines in bulk, as well as infrared cameras, for its members.

\section{Operations and Crews}

COAD has staff that provides QA for the member agencies. In many cases, it is one of these staff members that perform the initial audit and final inspection and the agency crew install the measures. This provides a third-party inspection of all jobs which is unique.

All of the COAD agencies favor using in-house crews over contractors when possible. Like many other local weatherization programs around the country, COAD members value employees who have both technical skills and a personal commitment to the mission of helping low-income clients with weatherization. It was remarked that people attracted to this type of work tend to stay in it; COAD members have enjoyed a very stable weatherization workforce over the past 30 years.

Because COAD members' weatherization programs generate strong word-of-mouth advertising, there is little need to advertise in order to get applicants for weatherization. All of the 17 member organizations are also traditional community-action agencies, so applications for weatherization come in from the Ohio Home Energy Assistance Program as well as from other sources.

Waiting lists for weatherization tend to be long; for example, the Gallia-Meigs agency has a waiting list of 435 (its average annual expected production is only about 80 homes). Like many agencies, COAD members use a points system to prioritize those on the waiting list; points are given to homes without heat; with elderly and disabled occupants; homes referred to the program by utilities; and homes with children under the age of 5. Cumulative time spent on the waiting list is also a consideration.

\subsection{ARRA PERIOD}

By the time of this case study visit, COAD and its members were ramping down from peak ARRA-period production. In general, COAD members increased their in-house crews during the ARRA period rather than relying on contractors. For example, Jackson-Vinton's weatherization staff grew from 8 to 21 and after the ARRA period, dropped to 14. Gallia-Meigs' staff increased to 39 and then dropped to 12 after the end of ARRA (See Figure 10.6). Overall, the majority of the staff that COAD members hired during the ARRA period has now been laid off.

The ARRA experience was a mixed blessing for many of the member agencies. While they were able to use funds to buy new vehicles and equipment (for example, Gallia-Meigs sold its older equipment and vehicles and purchased three new box trucks (See Figure 10.7) and two vans), laying workers off has been particularly painful, given that many of the workers needed the jobs and did not have other jobs in line. So is the realization that there are still approximately 250,000 income-eligible homes in the COAD region that could benefit from weatherization, which at pre-ARRA production levels would require many decades to complete. 


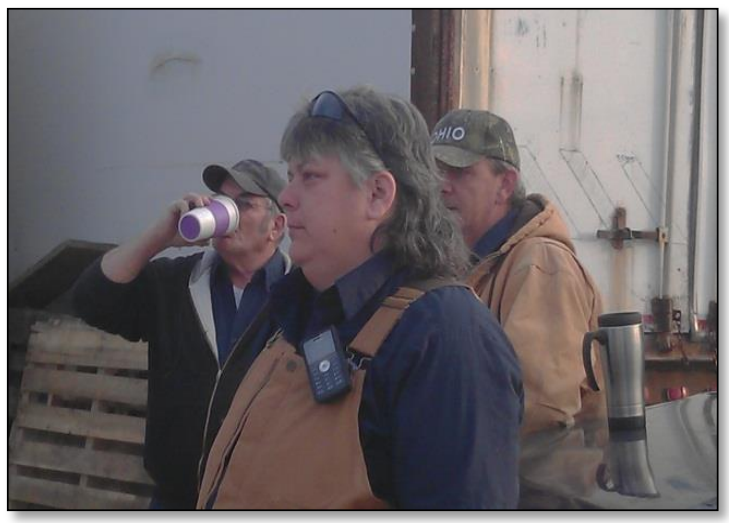

Fig. 10.6. Gallia-Meigs crew leader with crew

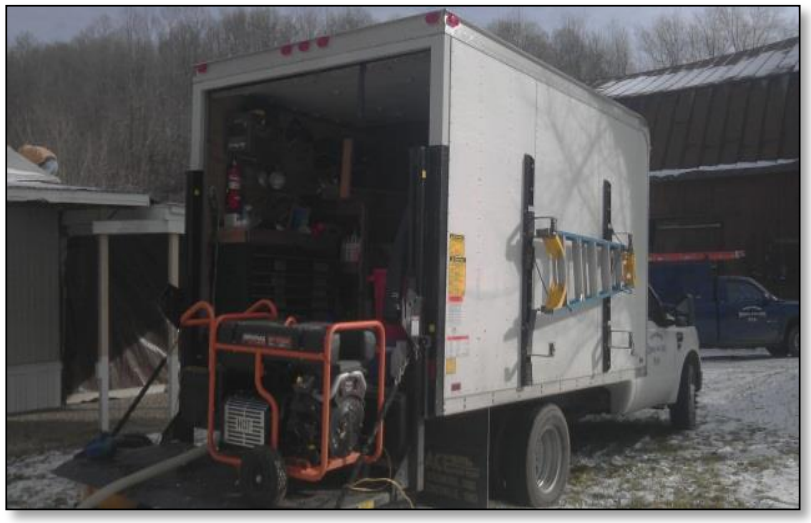

Fig. 10.7. Box truck purchased with ARRA funds

The greatly expanded production goals of the ARRA period stressed the COAD system. Ramping up was certainly a challenge, but having COAD's training facility and the benefits of the network to share lessons learned were very important in meeting the new goals. The priority on production led some agencies, like Gallia-Meigs, to reduce the time their staff could spend on energy education and general assessment of client needs. ARRA largess also had at least the short-term unintended consequence of interrupting COAD's aggressive leveraging activities.

\section{Davis-Bacon Act Issues}

COAD and its members did not suffer delays due to the imposition of the Davis-Bacon prevailing wage requirement because Ohio's state weatherization program provided crucial institutional support. For example, the state allowed Health and Human Services (HHS) funds ${ }^{25}$ to be used to ramp up equipment purchases and expand training opportunities. The members were also allowed by the state to estimate the prevailing wages and "true up" or even out wages later, after the prevailing wages were published. The wage rates themselves proved not to be an issue for agencies; for example, Gallia-Meigs was paying its crew above the rates in any case. Other agencies, such as Jackson-Vinton, have struggled to maintain the Davis-Bacon wage rates. Gallia-Meigs and all other COAD members were forced to hire a new person to keep track of Davis-Bacon requirements, like many local weatherization agencies around the country.

\section{Leveraging}

Leveraging funds for weatherization has been a way of life for COAD since its inception. It was stated that pre-ARRA, approximately 25 percent of COAD's weatherization funds came from DOE, with HHS accounting for more than 50\% and utilities accounting for the remainder. During ARRA, DOE funds covered the majority of weatherization expenses as Ohio backed off from providing HHS funds. PostARRA, COAD is planning to return to the previous arrangements and hoping that leveraging relationships suspended during ARRA will be renewed.

Pre-ARRA, almost all COAD weatherization jobs were "combos," meaning that two or more sources of funding were used to weatherize homes. All homes with even one dollar of DOE funding were weatherized under DOE rules, meaning that all measures need to meet SIR requirements among many other things. Because COAD has access to other funds and the rules about how the funds may be expended are somewhat less restrictive than DOE's, COAD does not find it necessary to defer many

\footnotetext{
${ }^{25}$ HHS funds or $15 \%$ of the Home Energy Assistance Program (HEAP) that the state receives from HHS.
} 
weatherization jobs — only around 5 percent. For these agencies, deferrals are mostly related to crew health and safety (e.g., when houses have mold or pest infestations).

Area utilities have proven to be valuable weatherization partners for COAD. For example, American Electric Power (AEP), funds an electric baseload program. Exxon Mobil has funded a green jobs pilot program. Other partners include Columbia Gas and the Electric Partnership Program, which is designed to improve the electric efficiency of low-income homes that participate in Ohio's Percentage of Income Payment Plan (PIPP) Program (in which low-income households pay a fixed percentage of their income for home energy regardless of how much energy they use). It is feared that PIPP may end up reducing the incentive for low-income home owners to save energy or to apply for weatherization because their bills will not go down even if they reduce their energy consumption due to this fixed percentage. PIPP-type programs also complicate the national WAP's allocation of benefits because in these instances energy savings benefits would accrue to rate payers and not the weatherization clients. The cost for providing the subsidy would be reduced but households would still pay the same amount for their monthly utility bill.

COAD is expanding its leveraging efforts as well. For example, the Lowe's home-improvement company is being courted as a partner, under the assumption that expansion of weatherization will increase demand for Lowe's products. Along these lines, COAD has plans to approach other retailers, appliance manufacturers, and even cellulose insulation producers. COAD is also exploring financial relationships with banks, credit unions, and utility companies.

As COAD's members ponder new directions, they are considering offering fee-for-service weatherization in order to expand into the non-low-income market. There would be a big learning curve and some are skeptical that the business would thrive in economically disadvantaged counties. On the other hand, they think they could compete with the private sector for skilled labor because they offer better health and retirement benefits than private-sector firms can.

\subsection{LOOKING TO THE FUTURE}

Moving forward, COAD and its members wish to expand into doing Weatherization Plus Health since lead contamination in older buildings is a particularly acute problem in this region, as are asthma and other health issues. The members would also like to focus more on helping the near-poor avoid actually falling into poverty. Like other agencies, COAD anticipates that its clientele will consist of more elderly and single-parent households in the future.

\section{Funding Levels}

With respect to the national WAP program, COAD would like to maintain the $\$ 6500$ average investment target because it provides more programmatic flexibility, especially in light of increasing requirements such as compliance with ASHRAE 62.2. COAD would like to waive the fuel switching prohibition (e.g., replacing a fuel oil furnace with a natural gas furnace) at least for homes that heat with wood and coal.

\section{Marketing}

COAD would like to see DOE focus on marketing weatherization to the American public; although weatherization is not a "sexy" topic, it saves lives and reduces energy costs. In addition, weatherization programs carry economic benefits because of the direct employment and multiplier effects that ripple through local economies. 


\section{DOE Support}

Additionally, COAD members would like to see DOE adopt some kind of standardized software tool that an auditor could take into a home and, on a laptop or touch-pad, help clients access all resources available to a given agency's clients (e.g., access to rebates, on-bill financing, etc.). DOE help in establishing alternative financing mechanisms would also be welcome, as would efforts to develop legislative incentives that support weatherization training.

\subsection{PROFILE}

\subsection{Weatherizing Murray City}

Murray City (Fig. 10.8 and 10.9) is a small town located in Hocking County, Ohio, deep within southeastern Ohio's coal country. At its peak, when coal was a booming business in the late $1800 \mathrm{~s}$, Murray City was home to approximately 30,000 people. By 2012, Murray City could count only 200 households, amounting to a population of approximately 450. Eighty percent of those homes qualify for low-income weatherization assistance.

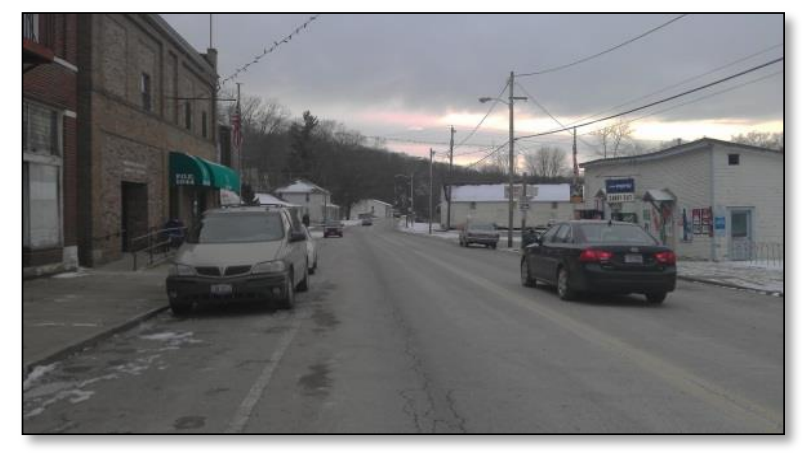

Fig. 10.8. Murray City, Ohio

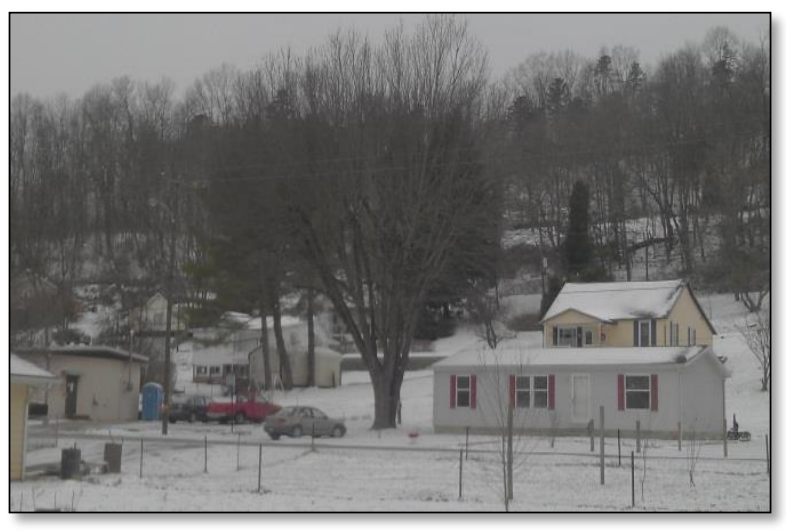

Fig. 10.9. Murray City, Ohio

One of COAD's longtime goals has been to weatherize an entire community. With ARRA funding and approval from the state weatherization office to waive priority list requirements, COAD embarked on a project to weatherize the entire town. WAP funding was used for income-eligible homes and private sector contractors were made available through the Home Performance with Energy Star Program (HPwES) for non-income-eligible homes. COAD's judgment was that weatherizing 200 homes located within a distinct community was an attainable goal. Rebates and other resources for the project were 
provided by AEP and Columbia Gas. Both income-eligible and non-income-eligible homes were identified. COAD conducted the audits for the income-eligible homes and Conservation Services Group (CSG) conducted the audits for the other homes. AEP Partnership with Ohio funds were used for healthand-safety repairs such as roofs and electrical upgrades.

Innovative programs need a champion, someone who can articulate the vision and follow through with persistence. The Housing Programs Manager for COAD, (Fig. 10.10) was the champion of this effort. Knocking on doors, he promoted the project, meeting in person with every household that participated in this project. At each home visit, he explained the project and provided 15-30 minutes of energy education as well. The political leadership of Murray City supported the project early on, and town hall meetings and weatherization open houses help to build momentum within the populace. The entire project was estimated to cost $\$ 1$ million, with approximately $\$ 8,000$ to $\$ 10,000$ invested per home.

One of the homes weatherized in Murray City is shown in Fig. 10.11. Built in the late 1800s as a theater, this building has been reincarnated several times, including as a business selling tombstones, until it became a single-family residence. The house received a full weatherization package, including ceiling and wall insulation, air sealing, and a new furnace (the old furnace had a crack and was producing $\mathrm{CO}$ ). The occupants, a young couple with a toddler and a baby on the way, reported a 30 to 40 percent reduction in their monthly natural gas bills.

This particular house was used as an "open house" to educate the community on the benefits of weatherization. The young homeowners were able to attest to the benefits of weatherization, thus helping to reduce skepticism about the program in the community.

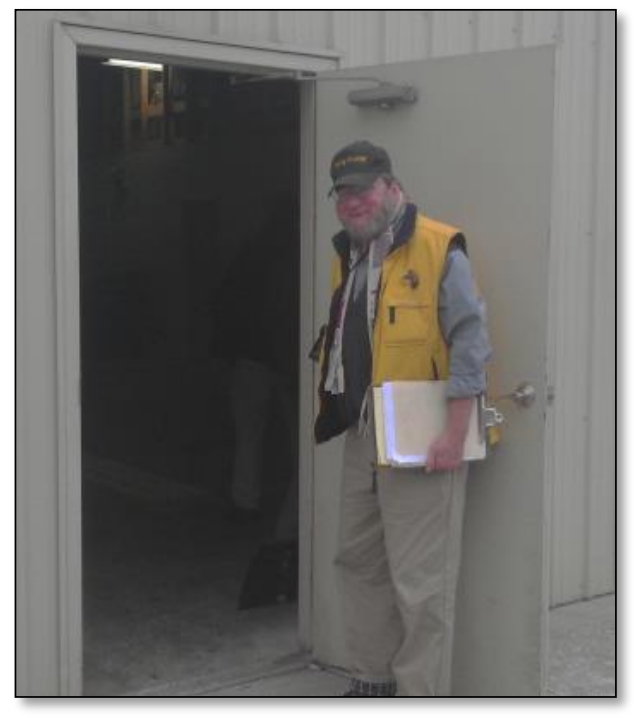

Fig. 10.10. COAD Housing Program Manager

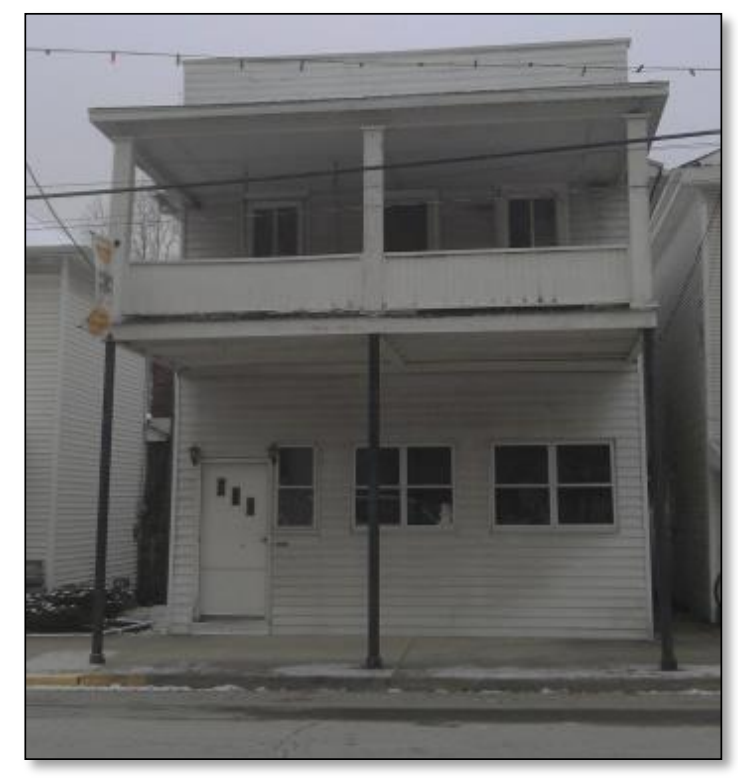

Fig. 10.11. Single-family residence in Murray City; renovated from 1800's theatre.

Initially, COAD's aim had been to focus on a town of about 20,000 residents, but the agency quickly found that major challenges faced them even in a community of only 200 homes. The paperwork required by the Hocking-Athens-Perry (HAP) Community Action weatherization program, much of which was also required by COAD, was a significant burden for both applicants and staff. Therefore, the paperwork process had to be streamlined in order to move the project forward expeditiously. 
In addition, the state of Ohio required that the names and Social Security numbers of all household members be included in the application. ${ }^{26}$ The COAD Director personally helped households with infants obtain Social Security numbers for babies that lacked them. Proof of ownership was also required before property could be weatherized ${ }^{27}$. As one could imagine, many of the properties in Murray City had been "in the family" for generations, with ownership and occupation rights understood but not legally identified. In many such cases, it was impossible to find ownership records, so COAD helped homeowners find alternative means to establish proof of ownership. Proof-of-income documents and SSI documentation were also sometimes difficult to obtain.

A third problem involved persuasion. Even though the majority of the village's households quickly signed up for weatherization, some landlords were hesitant to contribute their fair share to the weatherization of their units. Also, some stubborn householders were difficult to persuade for reasons of their own. For example, the owner of one of the last houses to be weatherized was a local government employee whose husband had passed away, significantly reducing her household income and dropping her own household into poverty. It was common for her and her daughter to huddle around the cook stove, their primary heat source, for warmth. She refused to have her home weatherized until all of the other eligible homes in Murray City were weatherized because as a government employee, she did not want others to believe that she was receiving preferential treatment. When only about 20 homes remained to be weatherized (and most of them not income-eligible) this woman at last agreed to have her home weatherized. The work included attic and wall insulation, plugging holes in walls and other air-sealing measures, and furnace replacement. The client expressed herself to the site team as very happy with the weatherization work and very comfortable in her "new" warm home. It was important to her that COAD was careful not to strip participants of their pride. Many residents in this area disliked the idea of a "handout" or any government assistance; they were accustomed to having to make a choice between buying groceries or paying their electric bills, but they did not want to be "beholden" to anyone.

Lastly, it took some effort to develop a working relationship with the HPwES, which provides weatherization services for non-low-income customers, in order to dovetail the types of services and provide roughly similar services to both income-eligible and non-low-income homes. The COAD audit tool and the CSG audit tool were quite different, and the weatherization measures allowable under WAP were not always the types of measures that non-low-income homeowners wanted most or would pay for, or that were eligible for rebates. There were also some tensions over the differences in the quality of the services being delivered by the in-house HAP weatherization staff and the HPwES contractor (in-house services were found to be higher in quality than the private contractor's). It was felt that lessons learned from this collaboration could benefit other communities seeking to combine low-income and non-lowincome programs.

\footnotetext{
${ }^{26}$ The requirement for the social security numbers stems from LIHEAP (Low Income Home Energy Assistance Program) requirements as Ohio uses HEAP (OH version of LIHEAP) to qualify the eligibility of WAP recipients.

${ }^{27}$ Proof of ownership was required for the homes weatherized through the regional Home Performance with Energy Star Program (HPwES).
} 


\section{ST. JOHNS HOUSING PARTNERSHIP - ST. AUGUSTINE, FLORIDA}

\subsection{INTRODUCTION}

St. Johns Housing Partnership (SJHP), of St. Augustine, Florida, originated in 1998 in response to the need for safe and affordable housing in St. Johns County (See Figure 11.1). Initially a basic emergency home repair program, the SJHP has grown to provide a weatherization program for homeowners, developed a green-certified community for first-time home buyers, created a program that provides foreclosure and credit counseling, and most recently expanded to include a multifamily weatherization program. These program expansions have contributed to SJHP's goal of rebuilding neglected homes and neighborhoods and encouraging local economic and social development. To assist with the implementation of this mission, SJHP has created links between the public and private sectors on projects that create low- and moderate-income housing. The agency combines funding from individuals, private foundations, corporate donors and government as well as blending a dedicated workforce of individuals and community volunteer support groups. As stated by a city representative, St. Augustine is a "city of restorers...restoration is at the heart of almost everything we do."

St. Augustine is the oldest continuously occupied city and port in the United States. St. Johns County contains some of the oldest housing stock in the country; there are homes documented to be close to 300 hundred years old in SJHP's coverage area, which includes, since 2011, neighboring Clay County as well as the original St. John's County. Occasionally, SJHP serves the great-grandchildren of original owners of homes. According to SJHP, many homes are in such a state of disrepair that they are condemned; however, for some families these homes have been passed down through generations and it is unthinkable to sell them (See Profile 8). These homeowners are, of course, dismayed that they may have to give up their family homes because they cannot afford necessary repairs; however, they cannot afford to relocate. Within the city of St. Augustine, 35 percent of all families with small children and 51 percent of single mothers with small children live below the poverty line.

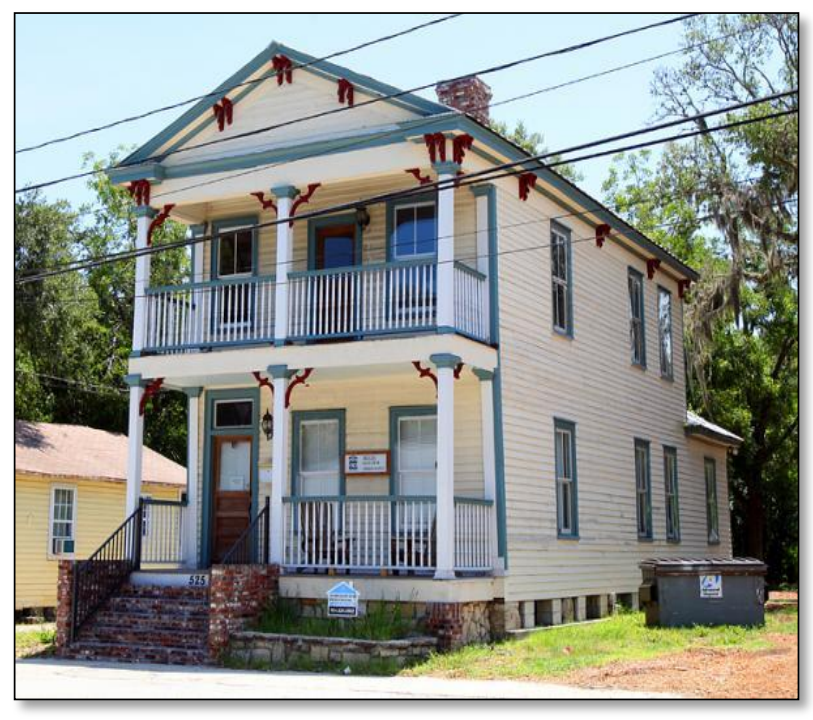

Fig. 11.1. St. Johns Housing Partnership 


\subsection{PHILOSOPHY AND APPROACH}

"Energy conservation is the mission of the program, but changes in lifestyle and quality of life is what we do." The agency focuses on helping its clients learn to save energy, thereby improving the quality of their lives through their own efforts.

\section{Organizational Structure}

During the ARRA period, SJHP utilizes four 2-person in-house crews for weatherizing single-family homes, 18 crew-members for MF operations, and additional Energy Audit contractors for rapid data collection with the multifamily program inspections (post-weatherization inspections are performed on 100 percent of jobs). For the high volume of work that SJHP produces, and to support overseeing the 20 counties for MF weatherization, SJHP also employs three regional managers, six administrative staff, and two support staff members.

\section{Outreach/Intake}

Most of SJHP's clients, approximately 75 percent, are referred by word of mouth; however, it was stated during interviews that staff have recently implemented an "old-school" marketing tool with a small-town feel. SJHP's informative material is tucked into a plastic bag, along with a small rock; staff members canvass neighborhoods that look as if they could benefit from the agency's services and toss the "packages" into front yards. In response to this low-tech approach, SJHP has had quite a few calls inquiring about their services. Brochures left in doctor's offices, cleaners, and Wal-Mart also bring in some clients. There are so many homes in disrepair and so many families in need within SJHP's service area that it is a challenge to keep up with the demand. However, the agency is still committed to increasing awareness of its services. At the time of the case study visit (Feb. 1 and 2,2012) there were 400 homes on the waiting list.

To increase efficiency and decrease inconvenience for clients, income eligibility is verbally confirmed during a pre-screening over the phone, and documentation is later provided by the client at the time of the home audit.

\section{Deferrals}

SJHP defers almost no weatherization jobs because, since it also runs a housing rehab program, SJHP crews are cross-trained to rehabilitate homes that cannot be immediately weatherized. SJHP uses its telephone screening to assess whether a home is likely to be a candidate for weatherization; this avoids spending resources on a site visit to a home that may need rehab first. In addition, SJHP's ability to creatively and effectively use multiple sources of funding demonstrates its dedication to serving weatherization clients and results in the almost non-existent deferral rate.

\section{Crews and Training}

All SJHP job candidates undergo a pre-screening that includes a personality and skill-set evaluation called the Core Values Index (CVI). This evaluation is seen as a way to make a connection between the essential nature of a person and the contributions inherent in their work. If a worker is hired, the CVI results allow for him or her to be appropriately placed and heighten the chances of a successful work experience. SJHP has established partnerships with local high schools for volunteer community-service projects, and some of these volunteers later apply for internship positions. 
SJHP's crews undergo initial training in building science and lead-safe weatherization, as well as continuing education in new technologies. According to Bill Lazar, SJHP's Executive Director (See Figure 11.2), "It is critical for our crews to be able to see the house as a system; to be able to see beyond individual weatherization measures. Crews need to know the why, not just the what."

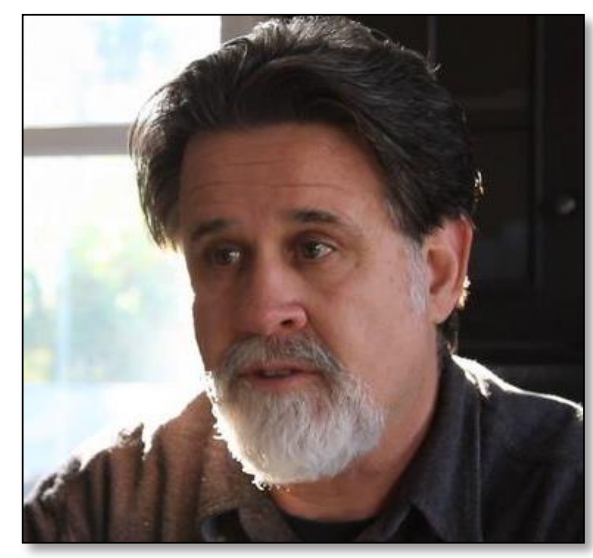

Fig. 11.2. Bill Lazar, SJHP Executive Director

Lazar believes this training encourages a stimulated, committed, informed workforce, which is the foundation for providing quality services. In addition to technical skill building, SJHP reinforces the philosophy that low-income clients should be treated with the same respect as anyone else. As Susan Giddens (See Figure 11.3 and Profile 11.1), SJHP housing rehab manager, tells her crews, "Don't treat the client any different just because the services are free. Treat them like they are paying you big bucks for your services."

\section{Innovativeness and Time Efficiency Techniques}

At the time SJHP's multifamily program was approved, the NEAT was the only software approved by Florida Department of Economic Opportunity (DEO). ${ }^{28}$ However, NEAT would not often calculate an allowable SIR value for an air conditioner replacement even if replacement appeared to be necessary due to inefficiency. Since NEAT based its calculations on the nameplate or rated efficiency of the installed air conditioner and did not account for system degradation, an alternative approach ${ }^{29}$ was established to derate the efficiency of HVAC equipment for use with NEAT software. The de-rated efficiency accounted for diminished efficiency due to the age of the equipment and how well it has been maintained. The intent of this approach was to justify using a SEER low enough to achieve an allowable SIR for HVAC replacements.

\footnotetext{
${ }^{28}$ The MulTEA (Multifamily Tool for Energy Auditing) was not created at that time; this is the multifamily audit tool currently being used by SJHP.

${ }^{29}$ This approach utilized a formula that was presented to SJHP by the Facilities Strategies Group (FSG) located in Fort Mill, SC. FSG based their approach on research conducted by National Renewable Energy Laboratory (NREL) and Proctor Engineering Group, Energy Investment Inc. This research presented several methods or correlations to quantify de-rated HVAC efficiencies. FSG then conducted an evaluation on a sample of multifamily units to confirm its efficacy.
} 
It was stated that it is still an ongoing frustration to SJHP that DOE does not recognize the importance of cooling systems, both to eliminate humidity in the house and to protect from excessive hot weather. In this region, it can be critical to provide a cooling system; "heat kills too."

Crew leaders, auditors, and inspectors are required to be certified on the blower door. Crews perform the blower door tests throughout the air-sealing portion of the weatherization process and continue air-sealing measures until an established Air Changes per Hour (ACH) level has been reached ${ }^{30}$.

Another issue expressed with regard to NEAT dealt with the unique way the state wanted agencies to use NEAT to analyze the cost effectiveness of just air conditioner and other system replacements. On a webbased training site (http://www.weatherizationassistanttraining.org/), "help videos provide information on how to generate and set up the library, but do not offer instruction on how to use the audit tool" in this unique way. To bypass these challenges, a measures assessment tool was developed ${ }^{31}$ in an Excel spreadsheet and NEAT data was transferred into it. This Excel spreadsheet also includes job status, budget, labor time, and labor cost; data are linked to a central server for on-site data migration. Staff then verifies the completed spreadsheet. The inspectors also have a complete digital system onto which their pre- and post- weatherization photos can be uploaded to the server.

Florida's weatherization agencies created a statewide network called the FWN (Florida Weatherization Network) to share best practices and support each other's plans for the future. Agencies share information through a website ${ }^{32}$ in addition to periodic statewide meetings.

\section{Leveraging}

SJHP has found it to be a challenge to manage uncertainties about budgets and programs; planning ahead is a precarious prospect due to uncertainties about cash flow. It was mentioned that it would be beneficial to be able to respond to federal or state notification for RFP's, etc., as well as tap into other potential opportunities for financial support if they could afford a grant writer on staff. SJHP has developed several leveraging resources, of which some are used for housing rehab in order to address issues that would normally result in deferrals. Leveraged funds come from a variety of organizations and sources:

- Health and Human Services, with general revenue from County sources.

- The State Housing Initiative Partnership (SHIP). The Sadowski Act increased the documentary stamp tax paid on the transfer of all real estate in Florida, creating revenue for the local SHIP program in all 67 counties and 50 entitlement cities in Florida. These funds are dedicated to promoting home ownership, building quality rental housing, preserving existing housing through rehabilitation, and preventing foreclosures.

- The National Stabilization Program (NSP) is a component of the Community Development Block Grant (CDBG) that was established for the purpose of stabilizing communities. NSP Grantees

\footnotetext{
${ }^{30}$ SJHP used the Minimum Ventilation Rate/Building Tightness Limit (MVR/BTL) in their calculations as recommended during the 2006 Florida whole-house weatherization training as part of DOE's Hot Climate Initiative (training materials can be found at: http://www.waptac.org/data/files/Website_docs/Training/Standardized_Curricula/Curricula_Resources/USDOE_Air _Sealing.pdf). For MF weatherization SJHP used the bedroom portion of the MVR/BTL as the number of residents changes from time to time.

${ }^{31}$ This assessment tool was developed by Indiantown Non-Profit Housing in Florida

${ }^{32}$ http://flwap.org/
} 
must use at least 25 percent of the funds appropriated for the purchase and redevelopment of abandoned or foreclosed homes or residential properties for very low income eligible families.

- United Way of St. Johns County.

- Private foundation funds (Buckingham Smith Benevolent Association). This foundation contributes up to $\$ 80,000$ per year; the foundation's mission is to provide assistance for AfricanAmerican clients.

- Volunteer labor (non-DOE projects). Volunteers create leveraging and community awareness opportunities and help with everything from building wheelchair ramps to exterior painting and landscaping projects.

- Florida Power \& Light and Progress Energy.

\subsection{TAILORING WAP TO FLORIDA'S CLIMATE}

Since WAP standards are not focused on the needs of homes in hot, humid climates, SJHP uses a climate-specific approach. Weatherization in this region needs to focus on controlling humidity levels within a house in conjunction with energy savings. For instance, careful attention needs to be paid to the proper design and sizing of the cooling system. Choosing units of the correct size and cooling output is critical. The most common sizing mistake is in over-sizing-installing an AC system that is too powerful for the square footage of the house. This not only makes the new system more expensive to install, but also forces it to operate inefficiently, break down more often, and cost more to operate. Oversized air conditioners do not run long enough to dehumidify the air, resulting in decreased comfort and encouraging mold and mildew, both of which can pose serious health problems for people with breathing difficulties or compromised immune systems. In addition, it was mentioned that when $\mathrm{AC}$ systems are replaced in multifamily buildings, if the compressor is swapped out but not the air handler, the system is mismatched. The new 2012 Florida Energy code specifically addresses this concern. It was indicated that 15 to 20 percent of expected energy savings could be lost with mismatched components and incorrectly sized cooling system replacements.

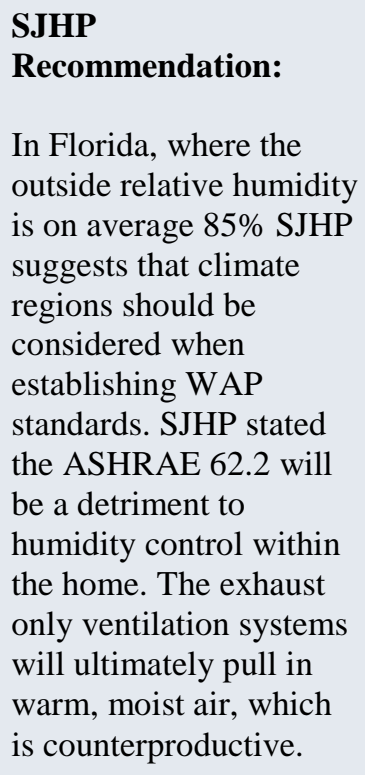

SJHP crew members stated that HVAC technicians often do not understand the necessity, or do not take the time, to use modeling software to analyze a house as a system. During interviews with SJHP, it was noted that the Florida building department has become stricter in enforcing new energy codes, increasing the frequency of cooling load testing. These new energy codes require that in order to justify the replacement of a AC unit, diagnostics must be performed by the HVAC contractor or a Residential Energy Services Network (RESNET) Home Energy Rating Score (HERS) certified rater. To comply with these revised codes, SJHP drew up its own version of a "commissioning letter" for contractors, which has increased contractors' accountability for testing/installation of AC units. With the multifamily program, SJHP used NEAT (as required by WAP guidelines) for determining priority guidelines based on individual SIR and HERS ratings to confirm the proper sizing of AC systems; the agency also produced 
Manual J and D specifications for bid procedures ${ }^{33}$. However, SJHP stated that HERS software helped with defining what was necessary for the Manual $\mathrm{J}$ and $\mathrm{D}$ specifications. If the HERS software is utilized correctly to calculate cooling loads for every room, then a properly sized system can be obtained.

\subsection{ARRA PERIOD}

At the beginning of the ARRA period, work was delayed due to issues with contractor training regulations; ARRA funds were not released until October 2009. OSJHP prepared itself, hiring an additional staff person to cope with Davis-Bacon Act requirements, and rapidly ramped up from weatherizing 8-12 homes per month to 50-60 homes per month in St. Johns County and up to 45 homes per month in Clay County. As of March 2012 SJHP had already exceeded its ARRA goal of weatherizing 1311 single-family homes.

\section{Multifamily Weatherization Program}

In June of 2011, SJHP inaugurated a MF weatherization program in addition to its existing single-family operations. The MF initiative, a one-time ARRA effort, offers services to MF properties and their residents across 20 counties in north Florida. The multifamily initiative was given an ARRA capacity grant to rapidly create and deploy a team and the processes necessary to identify properties, gather data, submit evaluations, and apply for individual project approval. The entire process from application to final Building Weatherization Report (BWR) was designed in an electronic format to expedite the process and save on after- contract storage requirements. However, SJHP said that they wished they had known about a 400-page guidance manual available at the WAP Technical Assistance Center's website and they recommended that it be better advertised. SJHP's Director of Construction, Thomas Stauffacher, oversaw the endeavor along with several new employees. It became a necessity to establish another headquarters specifically for MF operations. As of July 2012, SJHP had weatherized and stabilized 1243 units (35 properties) of MF rental housing. SJHP's role is to provide the oversight and construction management services for every project. SJHP's weatherization crews were expanded, trained and moved from property to property as the work schedule required.

\subsection{PROFILES}

Susan

During interviews it became apparent that staff and crews of SJHP shared common qualities; a sincere compassion and drive to do good for others. The single-family program manager, Susan (Figure 11.3), said she came to SJHP from the "for-profit" world in construction as a finisher and superintendent. She found that she receives so much positive feedback from clients that she was initially taken aback, but the hugs after a job, a baked cake, and lots of thank-you notes have been very rewarding: "Their [clients'] gratitude is something money can't buy." Summing up a widespread sentiment, she said, "We all know that we are involved with often dramatically increasing a client's quality of life, from living in some of the worst conditions to being able to pay their bills and live in a healthier, safer home. As a result, they change our lives, and that is the wealth we are creating together."

\footnotetext{
${ }^{33}$ HERS raters used Energy Gauge software to determine what the approximate savings would be after the work was completed. SJHP chose to have this done on different floor plans and orientations, which gave the building owner and SJHP a baseline for data if future information was to be gathered. In addition, the owner would need the HERS baseline if they would like to do more improvements and work towards getting a carbon credit.
} 


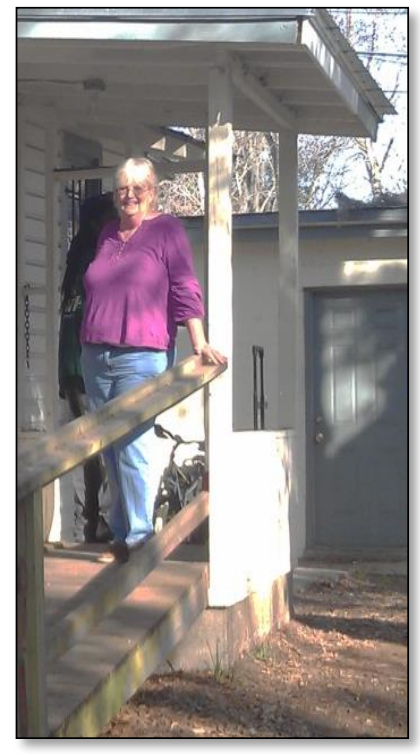

Fig. 11.3. Susan Giddens,

\section{Julie} single-family program manager

Julie was a stay-at-home mom while she ran a pre-school in her home for 20 years. When her children grew older, she wanted to return to the workforce, but did not have the marketable skills to move out of childcare. She was hired at SJHP at an entry-level administrative position. At the time of the site visit, she had advanced her computer and organizational skills to the level where she was tasked with the entire MF inventory and managing all pre- and post-weatherization images. She said that this position has been very inspiring and enlightening, she was "so surprised [at] how tough people have it."

\section{Mike}

Prior to working at SJHP, Mike worked at a CPA firm. Once hired at SJHP he saw the need to turn the MF office into a paperless operation; by working with field staff and learning the computer software on his own time, he succeeded in developing a user-friendly one-page spreadsheet which was then easily transferred over to the state's PLAT form. Tablet computers for MF inspectors were then purchased to support this upgraded digitized system.

\section{Kwanda}

A single mother of three sons with a permanent smile, Kwanda (Figure 11.4) was an unemployed electrical worker three years ago; at the time of the site visit, she was working for SJHP as crew leader of a two-person crew. "Thanks to SJHP, I have a good job, my boys and I have a nice home [which Kwanda helped repair], and I get to help people who have a whole lot less than I do. I am so grateful to be part of this team." She stated that the most challenging aspect of her job is not being able to do more for her clients. Some clients are in such great need but the repairs or services may not be allowable under WAP requirements. However, she notes, SJHP has a "pink slip" for documentation of needed repairs they will attempt to tackle when and if other potential funding sources become available. She has attended all the training courses she could, so far attending courses in lead renovation, building science, green building, and weatherization inspection. 


\section{Julius}

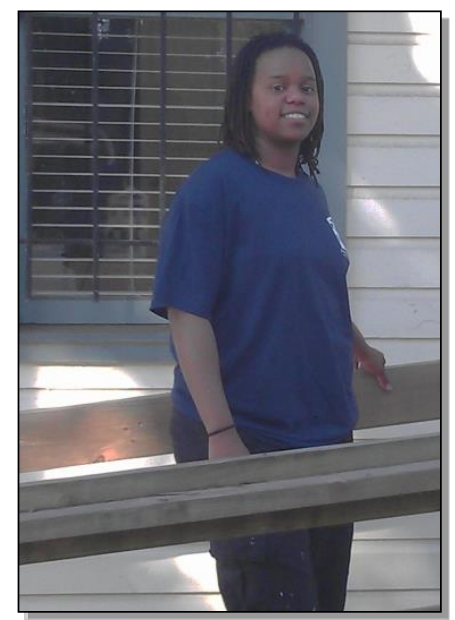

Fig. 11.4. Kwanda, Crew Leader

A shy young man with a bright smile, Julius (Figure 11.5) had in the past experienced precarious living situations; however he did not let go of his determination to graduate from high school. During this challenging time for him, he held an internship at SJHP. He felt that SJHP was a good way to utilize the skills he had developed while working for his father's home-improvement business since he was 13. After graduation, in addition to his internship with SJHP, he also attended culinary classes at a local community college. After six months as an intern, SJHP sent Julius to weatherization training courses, and he was hired as a full-time crew-member. When asked if he was going to stay in weatherization, he said he had not yet decided, as he has additional interests to explore. He followed that statement by adamantly, though shyly, stating that this job has had great benefits for him. "Every day I am going out to help somebody... which is very gratifying."

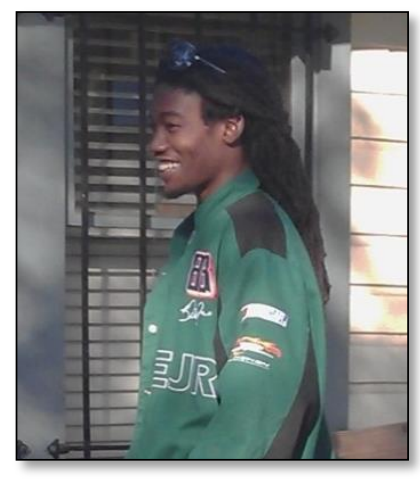

Fig. 11.5. Julius, Crew member

\section{Harold}

A perennial volunteer, Harold (Figure 11.6) volunteered for 10 years with Ramp Squad (a church group of retirees that has since 1999 built about 20 house ramps per year for mobility-impaired individuals, whose homes were also being weatherized by SJHP) and the "Pie in the Sky" food assistance program, personally delivering food to approximately 35 families every two weeks. Previously, Harold had owned a construction business, but when work slowed down he had to find other means of employment. SJHP 
hired him as a full-time crew leader. Harold is known for his quality craftsmanship and is very well respected among the crew members.

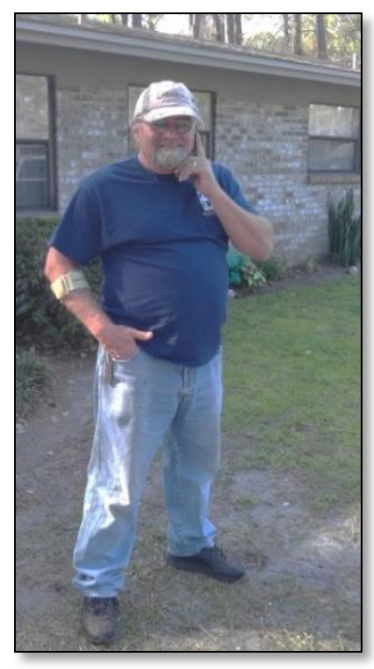

Fig. 11.6. Harold, Crew Leader

He said that he tries to do just one extra special thing for each client if he can. Humbly listing his volunteer activities, he stated, "If you give and it hurts, then you're not giving enough."

Harold's "extra mile" approach helped an elderly couple with serious health issues. The woman of the house shared her story about how she had been injured on the job as a nurse and forced to retire. Her husband had been unable to work for the past 30 years for health reasons, so both were dependent on Social Security alone. Harold exercised his customary extra care, making a point of reducing and containing dust, because he knew the client had respiratory problems, while building a new closet to house a larger heat exchanger (Figure 11.7). He also took care to install the same style door that was seen throughout the rest of the house and added an additional design touch. He minimized costs in other areas such as simply lubricating the exhaust fan rather than replacing it. He also left three air filters and educated the clients about how often and why to change the filter every month.

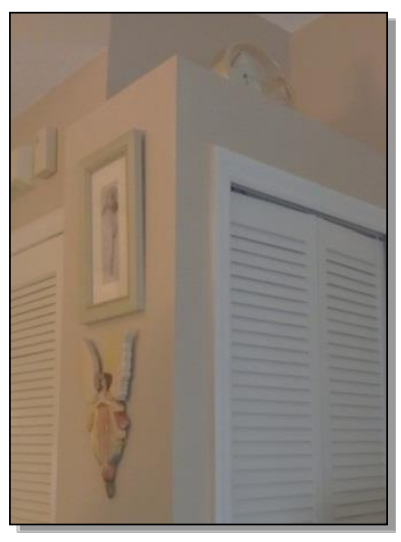

Fig. 11.7. Newly constructed closet for heat exchanger 


\section{Miss Johnsons' Family Home}

A retired school-bus driver and great-grandmother, Miss Johnson was attempting to win custody of her grandson from her daughter that struggled with drug abuse. However, her house was in such bad condition that the court considered it to be condemned and would not grant custody until it was repaired. Kids and grandkids would visit for family dinners, sit on the front porch in the evenings, and have a place to stay when in need, which she referred to as a "family home". For decades, it was many family members' home base. Over time, her home became uninhabitable, and she had to move into a camper in the back yard. Neither she nor other family members could afford to do the needed repairs, and Miss Johnson sank into a deep depression (See Figures 11.8 and 11.9).

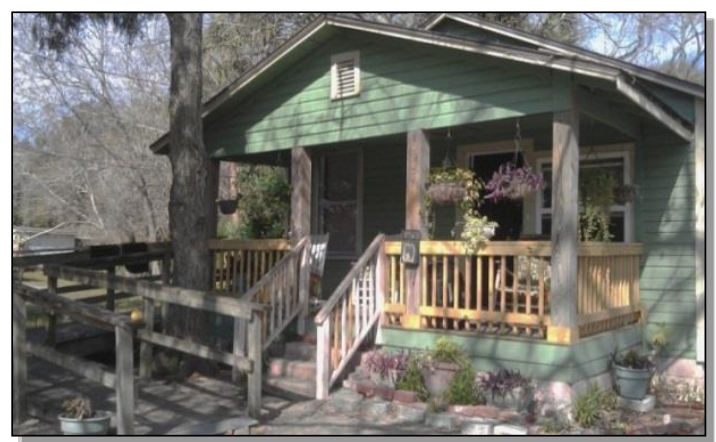

Fig. 11.8. Miss Johnson's home after finishing touches completed by family members.

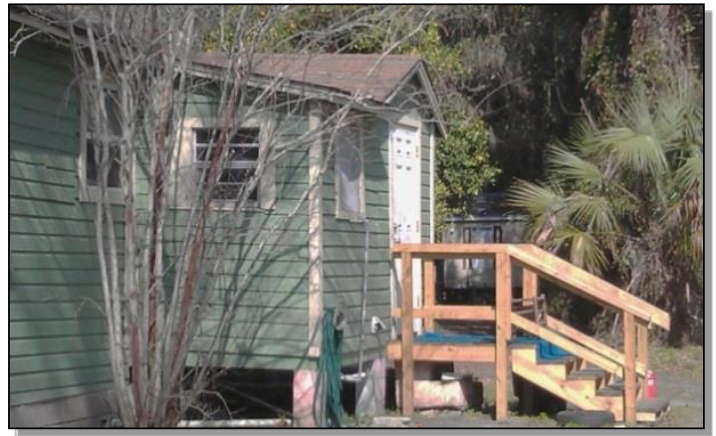

Fig. 11.9. Miss Johnson's home after complete rehab and weatherization.

SJHP pulled together as many resources and volunteer labor as possible. The SJHP uses the National "Make-A-Difference Day" campaign, to make improvements to weatherized homes. With $\$ 30,000$ of SHIP funds and private foundation funds, SJHP was able to replace the roof, windows, interior walls, porches, railings, and steps (See Figure 11.10 and 11.11). A crew of mobilized volunteers painted the exterior of her house. With WAP funds, her walls and attic were insulated, the aging HVAC system was replaced and solar screens were installed. Excited and motivated by the makeover, her family organized to complete the "finishing touches." They painted the interior of the home, cleaned up the yard, and filled her porch with thriving plants (Figure 11.10). On the site visit, Miss Johnson said she had been pulled out of her depressed state and was happy to have her life and her family back.

Mrs. Bing

The home Mrs. Bing had inherited from her mother (Figure 11.11) did not have running water, a kitchen sink, a toilet, or stairs; Mrs. Bing and her disabled son had to navigate bare wooden joists to get to the front door because the front porch was so damaged. For a complete housing rehab, volunteers and the construction community donated their labor and $\$ 45,000$ was pooled from leveraged funds. The home received a new roof, porch and stairs; running water, a sink, a toilet, and a water heater. SJHP fitted the house with insulation, air infiltration, two new doors, and an HVAC system from WAP funds. 


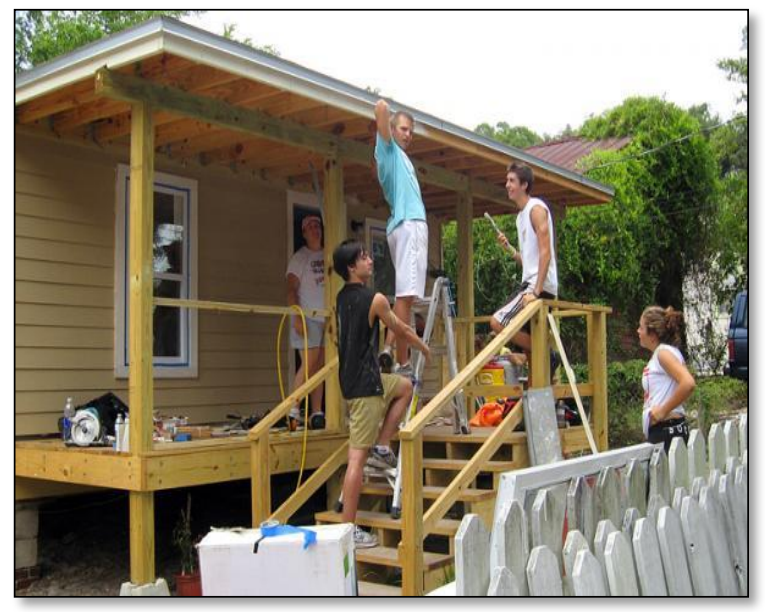

Fig. 11.10. Volunteers rebuilding porch on Mrs. Bing's home

\section{Southern Villas}

Southern Villas, an affordable rental community owned by SJHP, is a 60-unit MF home for retired seniors (See Figure 11.11). Many residents complained that the rooms did not heat and cool evenly. Most of the old heat pumps and AC systems were the original equipment from 1981. SJHP took this opportunity to experiment with an innovative MF HVAC technology, an inverted mini-split AC, which offers energy efficiency and flexibility in cooling various areas of a building. However, since this was the first time SJHP had performed this type of installation several "learning opportunities" were encountered, i.e. locating the temperature sensor in the living area rather than the attic. After relocating the sensor these residents are now saving close to 30 to 50 percent on their electric bills. Other weatherization measures installed included attic insulation, air sealing, low flow showerheads, faucet aerators, and insulation wrapping for pipes and water heaters. Residents are now able to keep affordably cool in the summer heat.

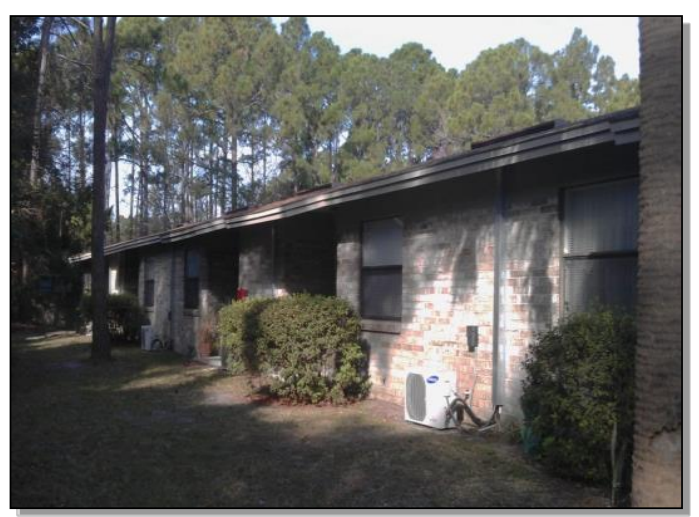

Fig. 11.11. Multifamily apartment house with inverted mini-split unit outside. 



\section{SOCIAL DEVELOPMENT COMMISSION - MILWAUKEE, WISCONSIN}

\subsection{INTRODUCTION}

The Social Development Commission (SDC) was founded in 1963 as the Community Action Agency for Milwaukee County, Wisconsin. Milwaukee County is located in the southeast of the state, on the southwestern shore of Lake Michigan. The county's population, as of 2010, was just under 950,000, of whom approximately 20 percent live in poverty. Over 11 percent are 65 years or older. Like many Rust Belt urban counties, Milwaukee County's population is diverse: 61 percent white, 27 percent African American, and 13 percent Hispanic.

Fifty-five percent of Milwaukee County residents own their homes, most of which were built before 1950, so the housing stock is relatively old. There are no mobile homes in SDC's weatherization service territory.

In terms of climate, the area gets less rain and more snow than the average American county (the average low temperature in January is around 12 degrees F). Thus, weatherization needs for this climate focus on energy efficiency and heat retention.

Currently, SDC serves Milwaukee County with a total of 30 integrated programs in five broad areas:

- Employment

- Asset Development

- Family Strengthening

- Education and Training

- $\quad$ Support Services

SDC uses a balanced scorecard program to ensure that all SDC programs are aligned and working in the same direction.

Weatherization services have been offered for about 10 years as part of the Asset Development division of SDC's programs, along with other programs such as Rehabilitation, the Neighborhood Improvement Program, and the Asset Preservation Partnership Program. SDC and a near-by agency, La Casa, took over the service territory of a failed weatherization agency, so in its present form, it is a relatively new program, quite open to new business management models and collaborations.

\subsection{PHILOSOPHY AND OPERATIONS}

The agency's mission statement, prominently displayed on its website, is, "Empowering Milwaukee County Residents with the Resources to Move beyond Poverty. Making a Difference Today, While Investing in Tomorrow." The weatherization arm of SDC takes its message into the community as frequently as possible, by participating in energy conservation demonstrations at neighborhood fairs and volunteering for Rebuilding Together of Greater Milwaukee to bring additional services to clients (See Exhibit 2). In rough neighborhoods, people perceive SDC staff as the "good guys." Wisconsin Works (W2) and Energy Assistance are the two SDC programs that interact most frequently with the weatherization program. 


\section{Marketing and Client Referral Process}

SDC does not do a lot of formal marketing. Most prospective clients are referred to weatherization from the SDC Energy Assistance Program, which serves about 40,000 clients. Prospective clients also directly contact the program when they hear about it by word of mouth. Marketing and client contact are complicated by the fact that SDC gets odd-numbered census tracts, and La Casa gets even-numbered ones. Sometimes, residents call the wrong agency because the job they saw being completed across the street was done by the other agency, not "theirs." There is a long waiting list for services (up to 200 households are commonly on the list) and there are frequently ethical problems in managing the waiting list (See Exhibit 1 for a detailed discussion).

SDC auditors do Healthy Homes assessments and photo documentation of problem situations, and they pass cases to the city health department as appropriate. Clients are also encouraged to call 211 if they need assistance beyond SDC resources.

Because Milwaukee's housing stock is old, SDC's auditors end up deferring about 50 percent of the homes they audit, mainly because houses in the area often are in poor condition and many have antiquated wiring that would make them dangerous to work in. Absentee landlords are also a contributing factor in failing to keep properties in sound physical condition. SDC finds that deferral rates are highest early in a given program year because this is when the clients whose homes are in the worst condition are referred by Energy Assistance to the weatherization program. Because Milwaukee has a high foreclosure rate, there is a risk that houses in the process of weatherization may be foreclosed. SDC is working toward better coordination with the city regarding foreclosures in order to prevent weatherization assets from being stolen when houses are foreclosed. SDC also must frequently deal with historic preservation issues and needs to determine on a house-by-house basis whether very old homes are on the Historic Register.

\section{Crews and Training}

Unlike most other Wisconsin weatherization agencies, SDC relies heavily upon contractors. It only has one in-house crew (down from two at the height of the ARRA period), but had 27 contractors at the time of the site visit. The in-house crew specializes in weatherizing the "shells" of homes, while the contractors cover all areas of weatherization. Auditors and inspectors, however, are permanent staff, not contractors, to ensure consistency and quality control.

To cut costs and improve efficiency, the SDC weatherization program has focused on improving its auditors' project-management skills. Rather than simply recommending weatherization measures, auditors are asked to address this question: "What is the most cost-effective way to do this job?" To help auditors answer it, SDC has developed a spreadsheet-based cost-estimator tool to get a better understanding of the costs of each component of a typical weatherization job. Estimated component costs are then compared to expected costs for doing the work either with an in-house crew, a single contractor, or with several contractors. Different clusters of weatherization measures are also reviewed to help match the job to the best mix of in-house/contractor crews.

To assure that the contractors selected for a job will do the best job possible, SDC carefully manages its relationship with them, from the bidding process to management and training. Approximately every other year, SDC solicits bids from contractors in the greater Milwaukee region. Weatherization measures are broken down into categories and further divided into items within categories. Any prospective bidder must bid on a mandatory list of categories and may add items from an optional list of categories.

Contractors bid on the work using dollar cost per unit of the weatherization measure (e.g., cost per square foot of attic insulation installation). The bidding process and structure render it easy to do category comparisons and line-item cost comparisons. 
SDC requires each contractor to have the following certifications:

- City of Milwaukee license

- State license for HVAC

- Lead-safe renovation (all contractors)

- Certificates of insurance

- Asbestos operations and management $(\mathrm{O} \& \mathrm{M})$ training.

SDC takes a proactive, collaborative approach to its relationship with its contractors. For example, the agency hosts monthly contractor meetings in its large conference room, and each contractor is expected to send at least one representative. At times, state program representatives may also attend the meetings. At the meetings, new initiatives from the state, feedback and accolades for contractors, problems/challenges, and better ways to do things are all topics for discussion. For example, one contractor shared an idea to use different sidewall insulation materials that would require less dense packing, saving money without sacrificing R-value.

SDC views its work with its contractor base not only as a labor-management issue, but as economic development for the area: all SDC auditors come from their community, and approximately 50 percent of SDC contractor businesses are minority-owned. In addition, SDC actively trains its contractors, thus giving them knowledge and skills that will help them compete in the larger marketplace. For example, one recent activity was a refresher course on lead-safe weatherization. SDC also works to encourage networking of its contractors to the larger community, for example through a Hispanic multi-cultural entrepreneurial network that provides business management assistance to small firms.

\section{Local Initiatives}

Because SDC asserts that weatherizing multifamily units is very cost-effective, SDC has been attempting to increase its number of weatherized large MF buildings. However, working with building owners has been difficult because many do not understand the concept of weatherization in general or the DOE requirement that WAP benefits must accrue to residents and not building owners. Wisconsin's WAP plan requires owners of multifamily residences to contribute approximately 15 percent to the cost of weatherization, and many building owners are reluctant to do this. Another factor complicating negotiations with building owners is uncertainty about total job costs. This was one motivation for improving the bidding process. SDC has found it better to overestimate job costs and refund the owner some money once the job is complete than to underestimate, hitting the owner with additional costs after the fact.

\section{Client Education}

Client education is an important component of SDC's weatherization program. Auditors spend extra time with clients to ensure they understand the benefits of weatherization and the weatherization process. Auditors give each head of household a Wisconsin Weatherization Customer Guidebook for information on the maintenance and upkeep of their new equipment. Likewise, contractors are instructed to explain their work and demonstrate the new equipment they are installing. Because elderly clients may be confused by equipment such as programmable thermostats, an SDC case manager follows up with each client after job is complete. 


\subsection{LEVERAGING AND COLLABORATIONS}

SDC's weatherization program actively seeks to leverage its WAP funding and enter into mutually beneficial collaborations. For example, SDC has collaborated with the State of Wisconsin on an on-thejob training program. The state put 40 candidates through a job readiness program administered by two local economic development agencies, Northwest Side CDC and Milwaukee Area Workforce Investment Board. SDC ran a 1-week Weatherization Boot Camp for participants who were interested in weatherization training. ${ }^{34}$ For a limited period of time, the states reimbursed candidates' new employers with one half of their new employees' salaries. From the pool of 40 candidates, SCD hired three, and its contractors hired four more. At the time of the case study visit, three of these individuals were still employed in the weatherization field, which SDC views as a successful outcome of this collaboration.

Another major collaboration is with the Neighborhood Improvement Project (NIP), which is funded by a Community Development Block Grant. The NIP focuses on housing code compliance issues. Recently, SDC and NIP coordinated work on 18 homes, deploying up to $\$ 30,000$ per home on repairs, plumbing, lead remediation, siding, and roof repairs.

SDC also works with the Milwaukee Housing Trust Fund to fund roof replacements prior to weatherization. In addition, leveraged funding is directly provided to SDC from the State of Wisconsin public benefits fund. Lastly, as mentioned above, SDC is increasing its focus on healthy homes. The City of Milwaukee Health Department has provided a pilot grant to help SDC incorporate health issues into its auditing process. Important health-related information gained during the audits will be shared with the Health Department.

\subsection{ARRA PERIOD}

As it was for most local weatherization agencies, the ARRA period was one of intense productivity for SDC, and 2,800 homes were weatherized. Because of the large increase in funding, SDC had to increase its contractor pool during the ARRA period but found that many contractors inexperienced with weatherization blindly bid for the new work. However, through diligent training and monitoring, most new contractors quickly learned the weatherization business.

\section{Davis-Bacon Act}

The Davis-Bacon Act prevailing-wages requirements did not delay SDC's production of weatherized homes during the ARRA period. SDC's contractors were hungry for work, so SDC moved ahead with work before the final Davis-Bacon prevailing wages were set. To address questions about compliance with the Act, SDC and La Casa hosted a day-long Davis-Bacon training session, and SDC hired an accountant to review timesheets, and to monitor contractors' compliance with Davis-Bacon requirements. Most contractors eventually adapted.

\section{Looking to the Future}

SDC supports keeping the cost target of an average of $\$ 6,500$ per unit, which allows the agency to accept more homes and defer fewer because of home condition. However, the new client eligibility threshold of 200 percent of poverty level is more problematic since there are already more than enough households that qualify at the old 150 percent threshold who need their homes to be weatherized.

\footnotetext{
${ }^{34}$ Weatherization Boot Camp article:

http://www.communityjournal.net/?p=3795http://www.communityjournal.net/?p=3795
} 
Going forward, SDC's weatherization program sees an uncertain future given the current economic and political climate. SDC plans on redoubling its efforts to communicate its program's accomplishments. It will also increase its efforts to build its base of leveraged funding and collaborations, especially in the health area. For the ARRA-era contractors, SDC is concerned that the sharp decrease in funding postARRA (SDC's target numbers will be reduced from 2800 to 700 homes per year) will push some good contractors out of low-income weatherization and maybe even out of business entirely.

\subsection{SUGGESTIONS FOR WAP IMPROVEMENT}

The weatherization team at SDC is caught between too much bureaucracy and too little support from the state weatherization office. They would like for program notices to be issued in a more timely fashion and for the state weatherization office to answer their questions more promptly, and they have found that staff and contractor management are made more difficult when budget allocations are not provided on time. Guidance from state and federal levels seems to focus more on what agencies ought not to do (e.g., with respect to OSHA, LSW, asbestos, radon) instead of how better to manage and expand their programs. SDC is especially interested in some positive guidance with respect to workforce and local economic development activities. Regarding the allocation of budgets, SDC would be interested in having WAP explore more competitive funding models to take the place of the current formula model. They would like funding to be based more on accountability and outcomes than on an a priori formula.

\section{Waiting List Issues}

With the reduction from ARRA-level funding, the SDC weatherization program has a very long waiting list. Applicants for the weatherization program typically are chosen from among the highest energy users of the Energy Assistance clients, and, as noted, the Energy Assistance program at SDC serves approximately 40,000 clients. Currently, about 200 homes are on the waiting list, and some have been on it for several years. Thus, the Energy Assistance program is limiting new applications for weatherization to keep the waiting list at this approximate size.

However, the problem remains that homes needing assistance with energy costs are often the very homes that need weatherization and repair: holes in the roof, broken windows, and other major structural problems create "leaky," energy-inefficient structures. WAP must defer about 50 percent of homes that it initially visits because WAP guidelines only allow a small investment in home repairs that are not a necessary component of a cost-effective energy measure.

One ethical issue arises when it is unclear where on the waiting list a home should be placed when it overcomes its deferral status. For example, in one case, it took a homeowner two years to repair the home to the point where it could be considered for weatherization. Obviously, this was a tremendous effort on the part of the homeowner. But, technically, the home was not on the waiting list because it had been deferred. Would it be fair to bump it up on the list to avoid another three or more years since the initial application? Or should the home have been added at the end of the waiting list? Another issue arises when a home is identified for joint services, but the partner agency needs to deliver its services before SDC can resolve, for example, a health-and-safety problem. To make the collaboration work in these cases, these homes might need to be pushed up to the top of the waiting list. SDC is working assiduously to build strong relationships with other service providers in Milwaukee County to develop a consistent approach. 
A third ethical issue involves placement of households on waiting lists. Designated priority households fall into five categories:

- Elderly persons

- Persons with disabilities

- Families with children

- High residential energy users

- Households with a high energy burden.

The specific ethical question is whether high priority homes should be added to waiting lists above lowpriority homes even in cases where the latter have been on the waiting list for an extended period of time. At the time of the case study visit, SDC had not yet directly addressed this issue. One solution implemented by another case study agency is to assign weights to all homes on the waiting list and to increase the weights for moving to the top of this list based on time on the list.

\subsection{PROFILES}

\subsection{Exemplary Service Delivery}

SDC and the non-profit organization Rebuilding Together of Greater Milwauke ${ }^{35}$ combined their resources to improve a home in SDC's service area. Rebuilding Together provided materials to fix up the home and SDC provided volunteer labor to install the materials and measures in the home.

The home in question is owned by a couple who has been married for 61 years and has lived in the house since the 1980s. Monthly electric bills averaged \$245, and the couple was referred to SDC's weatherization program through the Energy Assistance program. The initial audit revealed major structural issues with the home that should have led to its deferral. The collaboration between the two organizations made it possible to do the structural work and then to proceed with the weatherization. One Saturday, Rebuilding Together and eight SDC staff members volunteered their time; using materials provided by Rebuilding Together. The volunteer crew repaired drywall in the living room ceiling to support attic insulation, fixed the plumbing, repaired the foundation, installed siding on the garage, fixed the gutters and downspouts, improved site drainage, fixed minor electrical problems, installed grab bars in a bathroom, and removed debris from the crawl space to facilitate furnace and water heater replacement.

The weatherization measures installed by SDC included the following:

- New furnace, water heater with tank wrap, ground vapor barrier, air sealing, and crawl-space insulation

- Blown cellulose and air sealing in the attic (See Figure 12.1)

- New bathroom fan

- New refrigerator

\footnotetext{
${ }^{35}$ Rebuilding Together of Greater Milwaukee: http://www.rtmilwaukee.org/http://www.rtmilwaukee.org/
} 


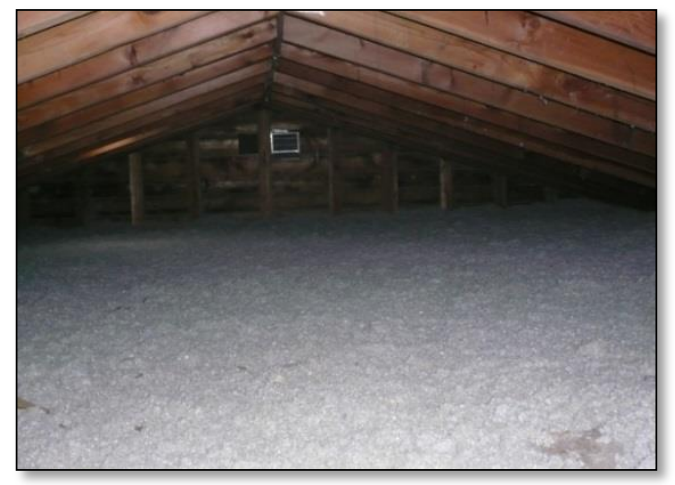

Fig. 12.1. Insulation in the attic protects the living space from cold.

The couple was very much involved with the entire home-improvement effort and is very pleased with the experience (See Figure 12.2). The husband assisted the crew by providing bolts, screws, and other hardware from his workshop when they needed it. Rebuilding Together commissioned a billboard and newspaper advertisements to celebrate the project.

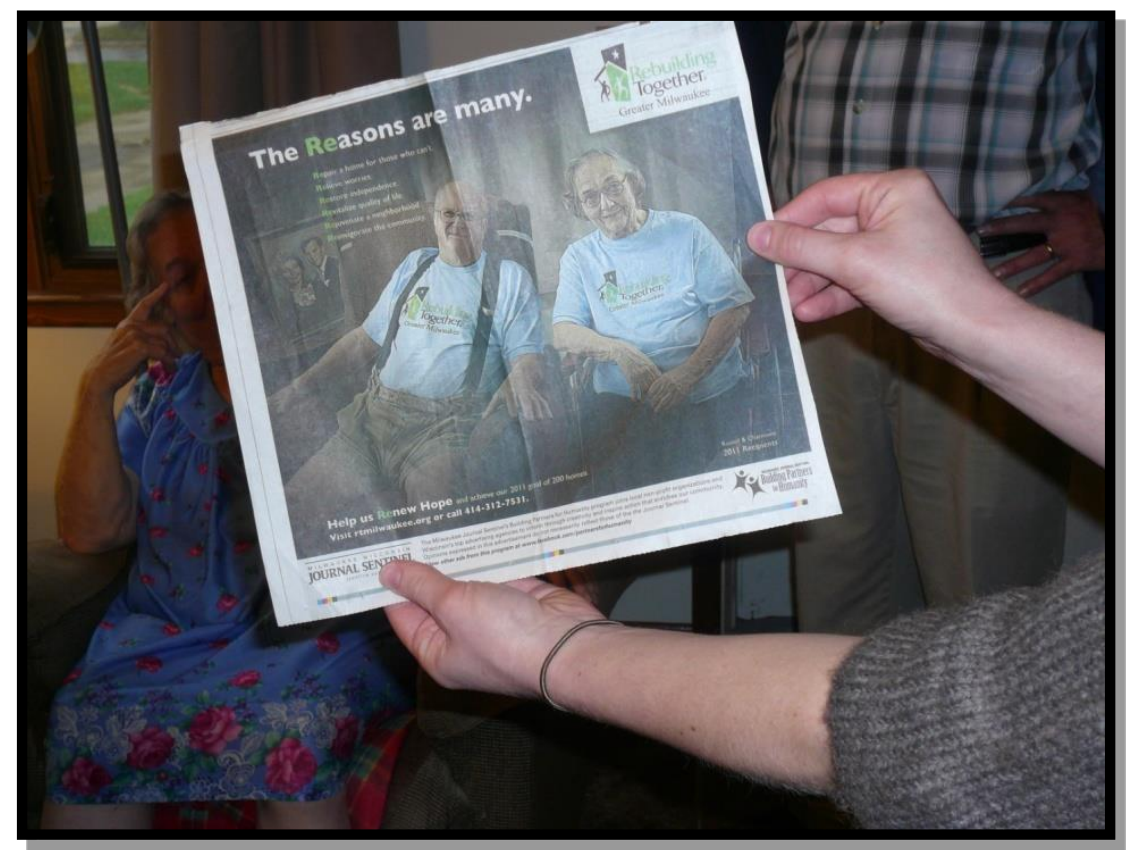

Fig. 12.2. The lady of the house laughs while displaying newspaper ad featuring the repair and weatherization of their home. 



\section{ASSOCIATION FOR ENERGY AFFORDABILITY - BRONX, NEW YORK}

\subsection{INTRODUCTION}

The Association for Energy Affordability (AEA), located in the Bronx in New York City, is one of the nation's leading weatherization agencies targeting the multifamily housing sector (See Figure 13.1). ${ }^{36}$ The organization was founded in 1992 as the Weatherization Coalition. It changed its name to AEA in 1994.

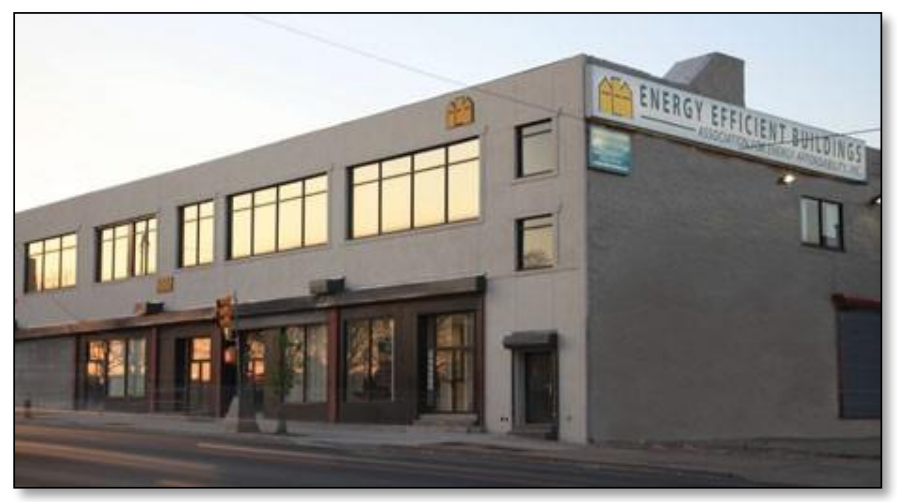

Fig. 13.1. Association for Energy Affordability, Bronx office

Due to the expertise it has developed, AEA has a presence on national boards and committees addressing and producing guidance, certifications, regulation, training curricula, and other resources for improving the energy efficiency of buildings. AEA also maintains office space in midtown Manhattan and has a satellite office in Emoryville, California.

Beginning by offering technical assistance and weatherization training, AEA's portfolio of services has grown and diversified over the years. In the mid-1990s, AEA assumed responsibility for conducting weatherization audits for almost all large and small multifamily buildings in New York City.

At the request of the State of New York, AEA also performs quality assurance on large multifamily audits conducted by others outside of New York City.

In recent years, AEA has added a state-of-the-art hands-on training facility, initiated a distance-learning program, and taken responsibility for operating a full-service low-income weatherization program in the Bronx. It also offers a fee-for-service program in the residential and commercial building sectors. These programs are discussed in more depth below. In addition, the following programs fall under AEA's weatherization programs:

- New York State Energy Research and Development Authority (NYSERDA) Home Performance with Energy Star

- Con Edison Multifamily Energy Efficiency Program

- NYSERDA EmPower New York ${ }^{\mathrm{SM}}$

\footnotetext{
${ }^{36}$ See http://aea.us.org/
} 
- NYSERDA Multifamily Performance Program

- Energy Upgrade California

- Clean Boilers Program for Weatherization

\subsection{PHILOSOPHY}

The large multifamily (LMF) buildings typically served by AEA are privately owned, although many are owned by non-profit organizations and house senior citizens or serve as supportive housing for vulnerable populations. AEA's guiding philosophy is that energy-efficient buildings are vital to community development and economic health, and that weatherization is key to energy efficiency. Thus, weatherization is at the core of AEA's efforts to serve low-income neighborhoods, keep housing affordable, and help make communities better places to live.

\subsection{MULTIFAMILY WEATHERIZATION APPROACH}

The barriers to comprehensive, whole-building weatherization of large multifamily buildings may seem insurmountable, but AEA works hard to dispel that perception. For example, DOE regulations governing weatherization of LMF buildings state that successful weatherization programs must meet two criteria: they must benefit building occupants, and owners must financially contribute to the weatherization project. AEA strives to overcome this barrier by establishing strong working relationships with LMF building owners, negotiating with them to meet the two basic requirements. With respect to the first requirement, owners are usually asked not to raise rents for several years post-weatherization. With respect to the second requirement, AEA has found that owners are more open to contributing toward weatherization when it is pointed out to them that they are actually investing in energy savings measures that will benefit them in the long run. In addition, AEA often informs owners that DOE WAP funds can supplement their investments in their buildings, thus facilitating the purchase and installation of new heating and cooling systems, new hot-water systems, more effective energy-management systems, more energy-efficient lights, and new windows. Owners are allowed to invest in measures that they really desire but that do not meet the SIR threshold, such as windows. In general, AEA tries to get owners to contribute 50 percent of the cost of the weatherization project, although the State of New York has provided AEA a waiver to reduce that amount to approximately 25 to 35 percent. Before an audit is conducted, owners are required to place into escrow a good-faith deposit of approximately $\$ 200$ for every unit in the building(s) to be weatherized.

Another myth that AEA works hard to dispel is that LMF weatherization is too complex to be practicable. The agency has found that the three keys to tackling the technical challenges of LMF weatherization are good data, good audit models, and a highly trained staff. To collect good data, AEA acquires two years of pre-weatherization energy bill records before they do the audit. Because almost all LMF buildings in NYC are centrally heated, this entails contacting local fuel oil and/or natural gas suppliers. AEA also collects electricity bills for master meter and individual unit accounts. These data provide the foundation for understanding how a particular LMF building is operating. 


\subsection{WEATHERIZATION DELIVERY}

\section{Determining Eligibility for WAP}

To identify buildings needing weatherization, AEA works with local weatherization agencies, passing along audit results and construction-oriented recommendations for associated agencies to implement.

Before weatherizing LMF buildings, AEA must first determine whether the building meets income thresholds for WAP funding. To be eligible for WAP funding, per New York's state plan, and a DOE rule defined in the Federal regulations, 66 percent or more of the households in a multifamily building must be identified as low-income; however, it is time-consuming to contact every household and obtain the requisite documentation (See Figure 13.2). The determination of income eligibility for a building is always done before the building is audited.

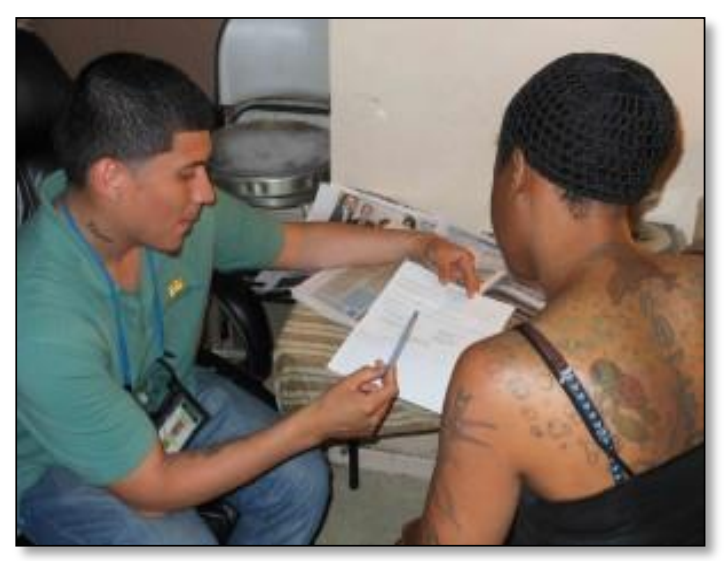

Fig. 13.2. AEA staff reviewing eligibility documentation with potential program client.

In addition, AEA must determine whether a building's condition may force a weatherization job to be deferred. WAP regulations ${ }^{37}$ allow 15 percent of WAP funds that are spent on a home or building to target health-and-safety issues. However, this amount is often not enough to deal with many issues, such as roof problems or asbestos remediation, or to remove health-and-safety risks for weatherization auditors and staff, such as rats in boiler rooms. AEA has to ensure that owners will deal with such building code violations before it will conduct an audit. AEA reports that more single-family homes than LMF buildings are deferred because NYC conducts regular and rigorous inspections on the latter, so they are generally in better condition.

\footnotetext{
${ }^{37}$ If a Grantee's plan calls for 15 percent or more of their budget to be spend on health and safety, that budget will be reviewed by a DOE committee. The 15 percent is a benchmark that most WAP agencies refer to. "As a part of the Health and Safety Plan, Grantees must set health and safety expenditure limits for their Subgrantees, providing justification by explaining the basis for setting these limits and providing related historical experience. It is possible that these limits may vary depending upon conditions found in different geographical areas. These limits must be expressed as a percentage of the average cost per dwelling unit. For example, if the average cost per dwelling is $\$ 5000,10$ percent would equal an average of $\$ 500$ per dwelling unit for health and safety. These funds are to be expended by Subgrantees in direct weatherization activities." (Source: WPN 11-6)
} 


\section{Audits}

AEA conducts numerous LMF audits per year and has a normal waiting list period of about one year, though the waiting list for LMF buildings during the ARRA period was two years. AEA's thorough energy audits document building characteristics as well as noting the normal energy-use information. AEA also asks the building superintendent and building manager about the building's energy system operation and maintenance as well as any complaints received from occupants about the warmth or coolness of their units. The auditors also query tenants directly about their experiences with the building's energy systems. Lastly, AEA's staff engineers perform technical analysis of the boilers and other highcost, central systems.

After all of this information is appropriately structured for input into a computerized MF audit tool called EA-QUIP, AEA selects measures to install in the building and generates a formal Apartment Building Work Scope (ABWS) document that details the recommended measures and estimated costs. This is then submitted to the building owner for approval of the measures and confirmation of the amount of owner contribution.

\section{Implementation}

After the owner approves the ABWS, the local weatherization agency implements the plan. For very complex jobs, AEA provides construction management services to the local weatherization agencies (e.g., for help with removal of old boilers and the installation of new ones). Every weatherized LMF building is inspected after weatherization.

The last step in the process is handing over the care of the weatherized building to its owners, manager, superintendent, and tenants. AEA has begun a program to provide formal energy system management training - a 5-day required class - to building managers and superintendents. In addition, boiler installers may be asked to provide training in the new systems they install. This program is funded by the NYSERDA.

To follow up, AEA tracks energy use in newly weatherized buildings and intervenes if anticipated reductions in energy use do not occur. AEA also educates tenants about energy use, showing tenants how they can better regulate heat in their units, for example, without opening windows in the winter.

\section{Organizational Structure}

Before the ARRA period, AEA employed 56 staff members (See Figure 13.3). This number grew to 138 at the peak of the ARRA period. At the time of the site visit (February 21, 2012), this number had decreased to 129 . 


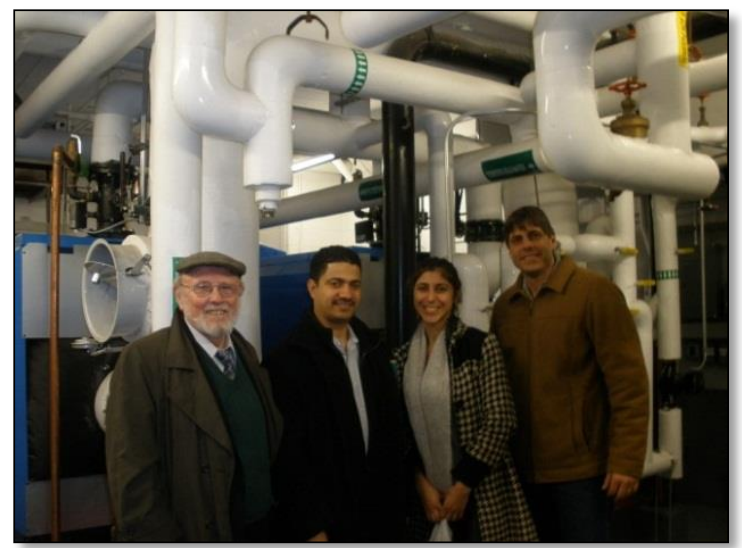

Fig. 13.3. AEA management and staff in a boiler room during site visit

Because AEA works in an extraordinarily rich multi-cultural environment, it takes care to hire culturally sensitive staff members with a range of foreign-language skills. To support its community-development goals, AEA also frequently hires career shifters and even former prison inmates, as long as the latter have earned their GEDs. To make this hiring strategy work effectively, AEA has a very strong mentoring program.

\section{Leveraging and Partnerships}

AEA works hard to leverage outside funding and to build partnerships that can help further its activities. Its main sources of leveraged funding are NYSERDA, the State of New York, and Consolidated Edison. Partners include the state's Department of Homeless Services, Office of Mental Health, Department of Aging, and Department of Labor, as well as the Consortium for Worker Education, the Osborne Association Green Careers Center, the Northern Manhattan Improvement Corporation, and various local community colleges.

\subsection{TRAINING CENTER}

AEA has a state-of-the-art training facility and is committed to sharing its knowledge about best practices. The facility contains simulated buildings and hands-on training stations related to air sealing, insulation, heating system repair and replacement, and AC system replacement (See Figures 13.4 - 13.6). For example, a mock-up can be configured to present students with air sealing and insulation challenges frequently found in attics of single-family homes. The mock-up is extensive enough (i.e., containing enough rooms) to allow students to do real-life blower-door pressure diagnostics and even combustion appliance zone (CAZ) testing and duct blasting. Instructors can change and/or set dampers to create different air-leakage and air-sealing challenges for students. The facility also supports CO testing on gas appliances and refrigerator metering (See Figure 13.6) and has a simulated crawlspace and a fully working bathroom. Overall, the facility allows instructors to replicate just about any situation that their students may face in the field. 


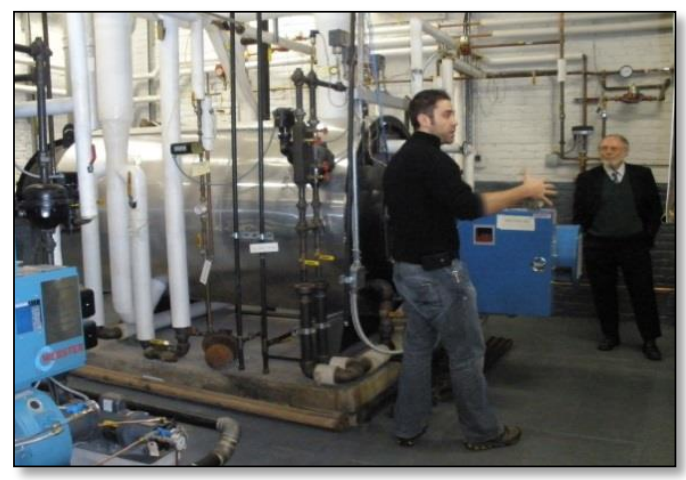

Fig. 13.4. Training station at AEA's training facility

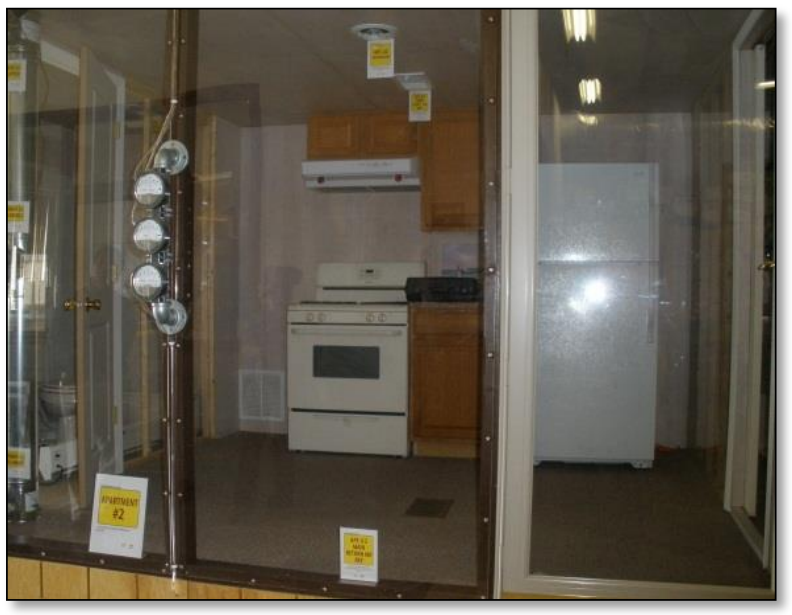

Fig. 13.5. At AEA's training facility, kitchen mock-up for $\mathrm{CO}$ testing on gas range and fridge metering

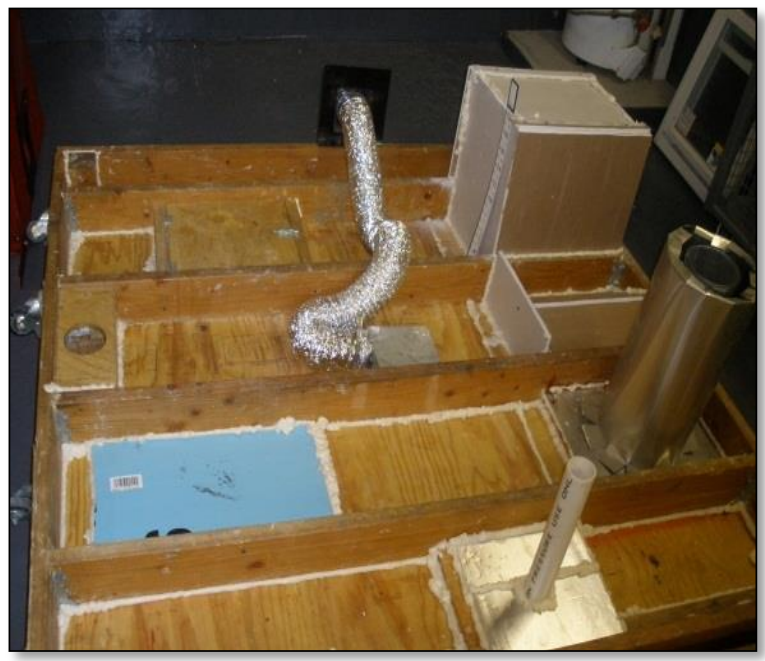

Fig. 13.6. At AEA's training facility, a training station for hands-on work 
Approximately half of AEA's students are involved with multifamily weatherization; the rest focus on single-family homes. AEA offers multiple certifications:

- BPI certification for crew chiefs and crew members

- Air Barrier Association of America certification training

- Continuing Education Units

- Passive House Consultant and Tradespersons certifications, and

- USGBC certification for Green Professionals.

AEA has also offered various custom-designed courses for interested businesses and organizations. In addition, the agency trains state weatherization office staff, NYSERDA home-retrofit contractors, and some Home Performance with Energy Star contractors. Finally, AEA collaborates with local community colleges, such as Hudson Valley Community College, to offer weatherization training, some of which can lead to BPI certification. Many AEA students are actually hired by AEA after they complete their training.

A good deal of effort is needed for AEA to maintain its training program. Collaborations with a wide range of organizations have to be established and nurtured; cash flow is often an issue, since students may have trouble paying for classes; the organization must leverage federal, state, local, utility, and foundation grants to subsidize training and support; and the funding seems to come and go. For example, NYSERDA's Multifamily Performance Program reimbursed 50 percent of AEA costs for several training offerings for many years, until this past year.

\subsection{ARRA PERIOD}

The ARRA period brought, along with heightened funding and expectations, additional administrative burdens. As with many weatherization organizations, the Davis-Bacon provisions of the American Recovery and Reinvestment Act of 2009 initially adversely affected AEA. For example, at the beginning of the ARRA period, AEA had already completed audits for approximately 100 LMF buildings but had to postpone weatherization for many months until the labor category wage rate was settled. Once the labor rates were determined, AEA costs for electricians went up significantly during the ARRA period.

\subsection{POST-ARRA PERIOD}

As AEA contemplates the post-ARRA period, it would strongly prefer to retain the $\$ 6500$ average costper-unit allowance instead of returning to the pre-ARRA $\$ 2500$ per-unit amount; the higher average has allowed for a more comprehensive approach in LMF buildings.

Going forward, AEA hopes that DOE will continue to expand its awareness of and support for LMF weatherization. AEA and other agencies have demonstrated that barriers to LMF weatherization can be overcome and that New York City's experiences can be applied around the country. AEA suggests that the following actions would make weatherization more effective in LMF environments:

- Make training for building superintendents an allowable cost under WAP

- Allow agencies to offer refresher training to building superintendents 
- Allow agencies to return to LMF buildings to fine-tune newly installed boiler systems (See Figure 13.7 and 13.8)

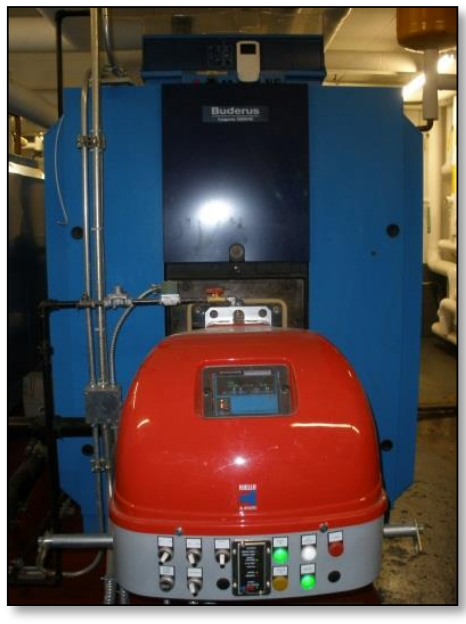

Fig. 13.7. Boiler installed by AEA

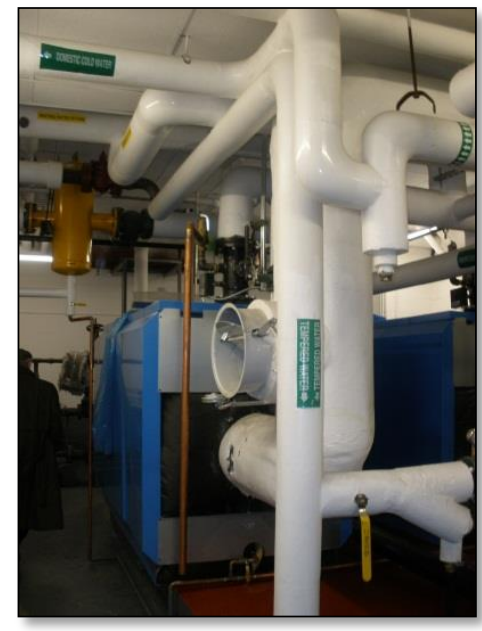

Fig. 13.8. Boiler system installed by AEA

- Institute more formal tenant protection regulations (e.g., prohibiting rent increases postweatherization), and

- Allow environmental benefits to be added to the numerator of the Savings-to-Investment Ratio equation.

\section{Challenges for the Future}

AEA hopes that more LMF building owners, both low-income and non-low-income, will consider weatherizing their properties. The biggest obstacle is a lack of confidence on the part of building owners and finance organizations that LMF weatherization will result in enough energy savings to provide a sound payback to the investment. To answer those doubts, AEA cooperated with a study supported by Deutsche Bank to estimate the energy cost savings attributable to the weatherization of LMF buildings. ${ }^{38}$ Overall, the study found that weatherization, on average, is a cost-effective investment but that energy cost savings varied considerably between buildings. To deal with this variation, financial institutions need to treat weatherization loans, like every other type of loan, from a portfolio perspective.

Whatever the future holds, AEA will continue to innovate. Currently, it is experimenting with rooftop photovoltaic cells, a green roof, and even a green wall on its rooftop (See Figure 13.9). It is also testing out two different solar thermal panels for their applicability to the LMF environment. In its facility, it has begun testing new equipment for manufacturers, starting with condensing boilers. Recently, it has entered into a partnership to promote passive housing. Lastly, AEA will continue to evolve and innovate to develop markets, such as new construction; the municipal/state, university, school, and hospital markets; and training for market-rate commercial building retrofits.

\footnotetext{
${ }^{38}$ See https://www.db.com/usa/img/DBLC_Recognizing_the_Benefits_of_Energy_Efficiency_01_12.pdf
} 


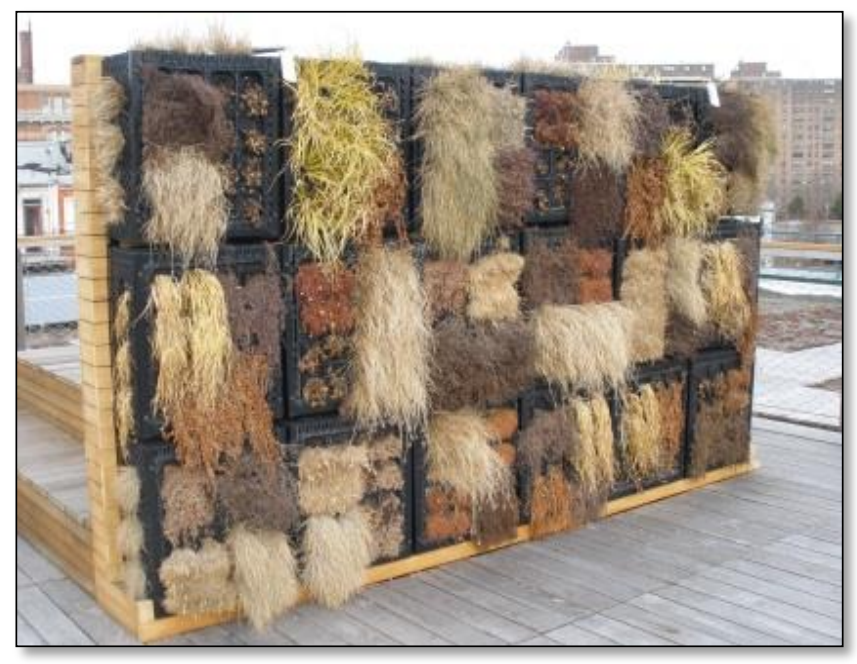

Fig. 13.9. Green wall (in February) - AEA rooftop

\subsection{PROFILES}

\subsection{Distance Learning}

AEA has developed a sophisticated distance-learning capability, the first of its kind in the weatherization community. The hub of this operation is a studio-classroom in its Bronx office. The room is equipped with three cameras and is manned by a communication systems professional with experience in daytime television and the production of independent films. The system has a T1 connection, which allows high band-width communications with its partner sites:

- New River Center for Energy Research and Training,

- Corporation for Ohio Appalachian Development (COAD),

- Community and Economic Development Association of Cook County,

- Building Performance Center/Opportunity Council,

- Indiana Community Action Association,

- Southwest Building Science Training Center,

- FSL Home Energy Solutions, and

- Southface.

Using its high-tech classroom, AEA can offer conventional distance learning courses in which experts can lecture and share their PowerPoint slides and whiteboard images, and in which students from other sites can interact with the teacher and other students in real time.

Additionally, AEA is developing powerful educational software. For example, AEA has developed detailed animations of the combustion systems typically found in LMF buildings. The animation graphically illustrates important combustion-related concepts that are otherwise quite difficult to teach in 
a lecture-only format (See Figure 13.10). AEA's future vision for this facility and program is to offer the best weatherization training, available anywhere in the United States over its distance-learning network.

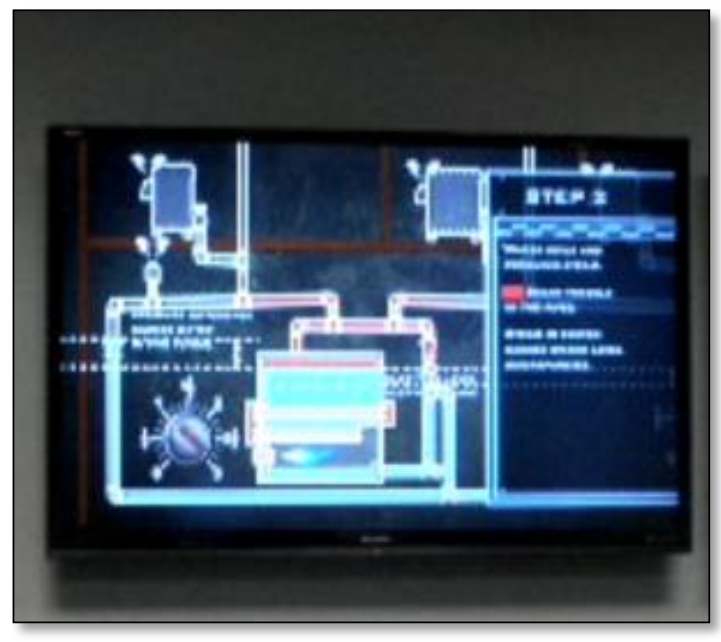

Fig. 13.10. Animated demonstration for distance and in-class instruction

\subsection{Senior Housing}

The case-study team visited several LMF buildings in New York City that had received weatherization services. Shown in Figure 13.11 is a 145-unit building that houses senior citizens. Just under $\$ 400,000$ was invested in this building (including a 25 percent owner contribution). The AEA staff audit of the existing heating system found an over-sized non-condensing boiler system that was ineffective and inefficient and did not allow the temperatures inside to reach a comfortable level for the elderly residents. The boiler was replaced with a 90+ efficient condensing boiler system. Upon installation, the levels of modulation, or appropriate minimum and maximum water temperatures, were set.

The 90+ efficiency referenced above is not automatically achievable; however, AEA's training and follow-up protocols ensure that the boiler efficiency target can be met. A superintendent is now trained to be able to fine-tune the system through a complete heating and cooling season. Occupants' feedback on comfort levels, and actual energy-savings impacts are being tracked.

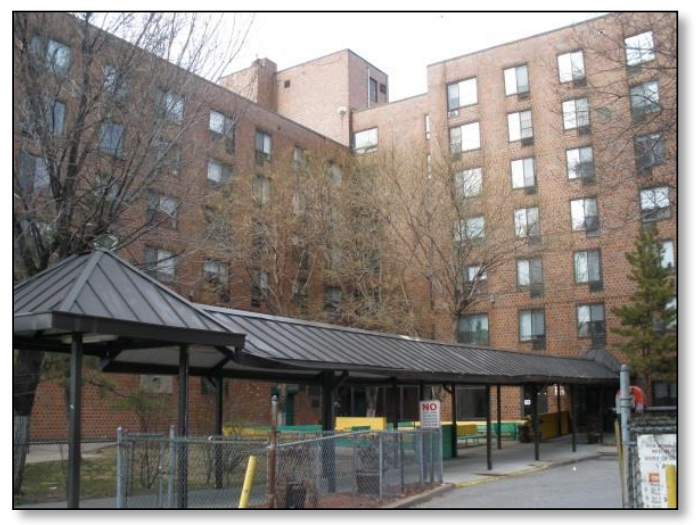

Fig. 13.11. Senior Citizen home weatherized by AEA.

(Note: Upper-floor windows are closed, which is indicative of uncomfortable heat distribution. Uneven heat distribution is a common issue with MF buildings). 


\section{NORTHERN MANHATTAN IMPROVEMENT CORPORATION, NEW YORK}

\subsection{INTRODUCTION}

In 1981, the Northern Manhattan Improvement Corporation (NMIC) enlisted the federal Weatherization Assistance Program in its quest to preserve affordable housing for financially strapped households. For more than 30 years, NMIC has dedicated itself to establishing and implementing social service programs and projects that target the needs of vulnerable populations in Manhattan's Washington Heights and Inwood communities. The Weatherization Assistance Program contributes to the preservation of affordable housing by educating, negotiating and partnering with owners, managers, supers and tenants of affordable housing buildings to achieve reductions in energy and water usage at both the building and the unit levels. Testimonials from these stakeholders attest to the change occurring as a result of NMIC's WAP projects. But the complexities of MF weatherization are such that even members within the National WAP network hesitate to take them on.

NMIC and its Weatherization Program are closely identified with the people who brought it into being and have since dedicated themselves to its cause. In 1979, Barbara Lowry incorporated this nonprofit to address the crisis in affordable housing in the Washington Heights and Inwood communities. She continues to serve as the agency's Executive Director. Twenty years ago, Dan Rieber (See Figure 14.1) joined NMIC's weatherization team and is currently the Director of Weatherization. Both Barbara and Dan have been instrumental in establishing partnerships, promoting tenant advocacy, and negotiating with building owners. A third key member of the NMIC team is Robert Mercado, a crew chief who brings both technical skill and a tremendous capacity for empathy for the people his program serves. Their imprints are defined and preserved in the work they do, and in the very buildings they weatherize (See Figure 14.2). A representative from New York State's WAP monitoring office emphasized that it is the people of NMIC who have made the organization what it is. It is the people that effect change.

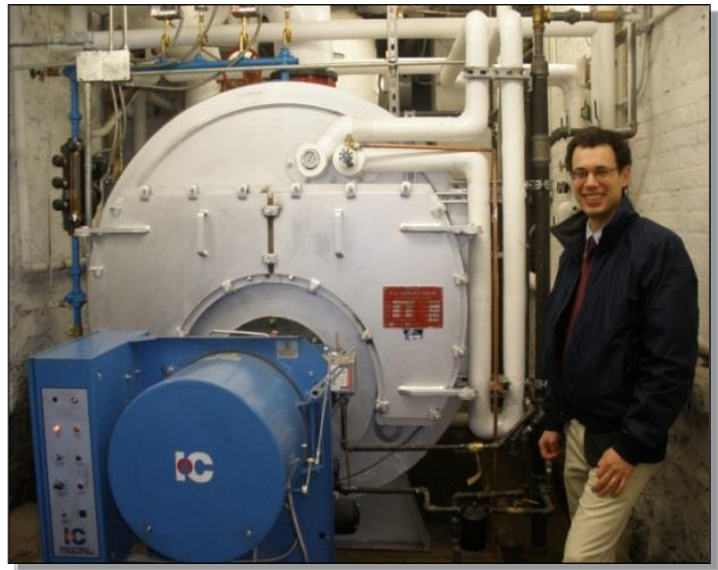

Fig. 14.1. Dan Rieber, NMIC Weatherization Director

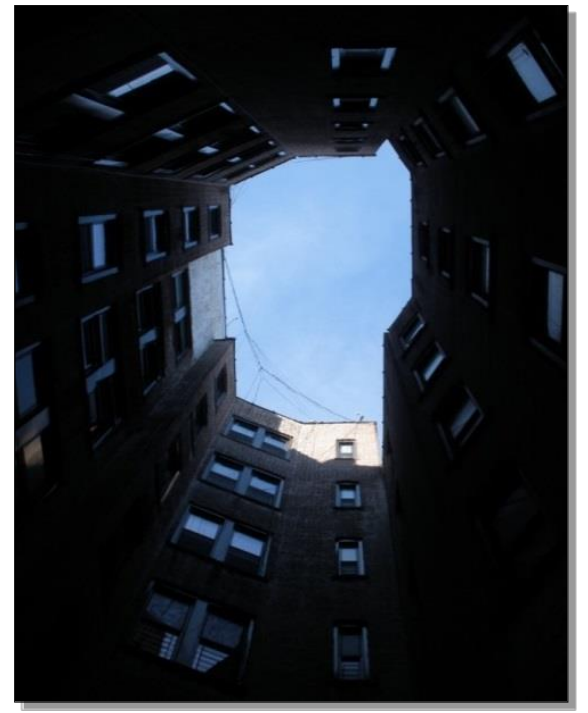

Fig. 14.2. View of sky from courtyard of multifamily residence recently weatherized by NMIC 


\subsection{OVERVIEW OF NORTHERN MANHATTAN IMPROVEMENT CORPORATION}

NMIC and its 100 staff members oversee a number of social-service programs, of which WAP is only one. The programs operate separately from one another but communicate with each other to comprehensively address poverty-related issues through both direct services and capacity-building opportunities. The following programs are included under NMIC's umbrella:

- Adult and Community Education

- Capitalize Benefits Screening and Enrollment

- Community Health

- Domestic Violence Services

- Employment and Training

- Immigration

- Organizing and Housing Development

- Legal Services

- Weatherization

Service Territory

NMIC provides WAP services in northern sections of Manhattan (See Figure 14.3); it also partners with other WAP Subgrantee in other service territories in Manhattan. In addition to working in the Washington Heights and Inwood communities, NMIC partners with the Cooper Square Committee, a community development committee/businessmen's association, "working to preserve and develop affordable and environmentally healthy housing and community/cultural spaces on the Lower East Side." ${ }^{39}$ NMIC also weatherizes about four small multifamily buildings per year for the neighboring Harlem CDC WAP Subgrantee, as that agency does not weatherize small residential buildings within its service territory.

\section{Weatherization Philosophy}

NMIC's general mission, which also guides its weatherization philosophy, is to "[s]erve as a catalyst for positive change in the lives of people in our community on their paths to secure, violence-free, and prosperous futures." Dan Rieber and his agency's vision for WAP provide a means for achieving this mission through the energy and non-energy benefits directly observed and generally attributed to weatherization. The non-energy benefits accruing to tenants through NMIC's WAP services include but are not limited to:

- Preservation of affordable housing by driving down utility costs and entering into agreements with building owners that limit or prevent rent increases.

- Health and safety benefits related to ventilation, pest management, and the installation $\mathrm{CO}$ and smoke detectors.

\footnotetext{
${ }^{39} \mathrm{http}: / /$ westbeth.org/
} 
- Improving comfort in the home.

According to Rieber, Washington Heights contains the largest number of affordable housing units in New York City. NMIC also promotes weatherization as a key ingredient in the "green" movement. In its view, conserving energy is a means to reduce the consumption of fossil fuels and their greenhouse gas emissions, as well as a way to decrease the United States' dependence on foreign oil.

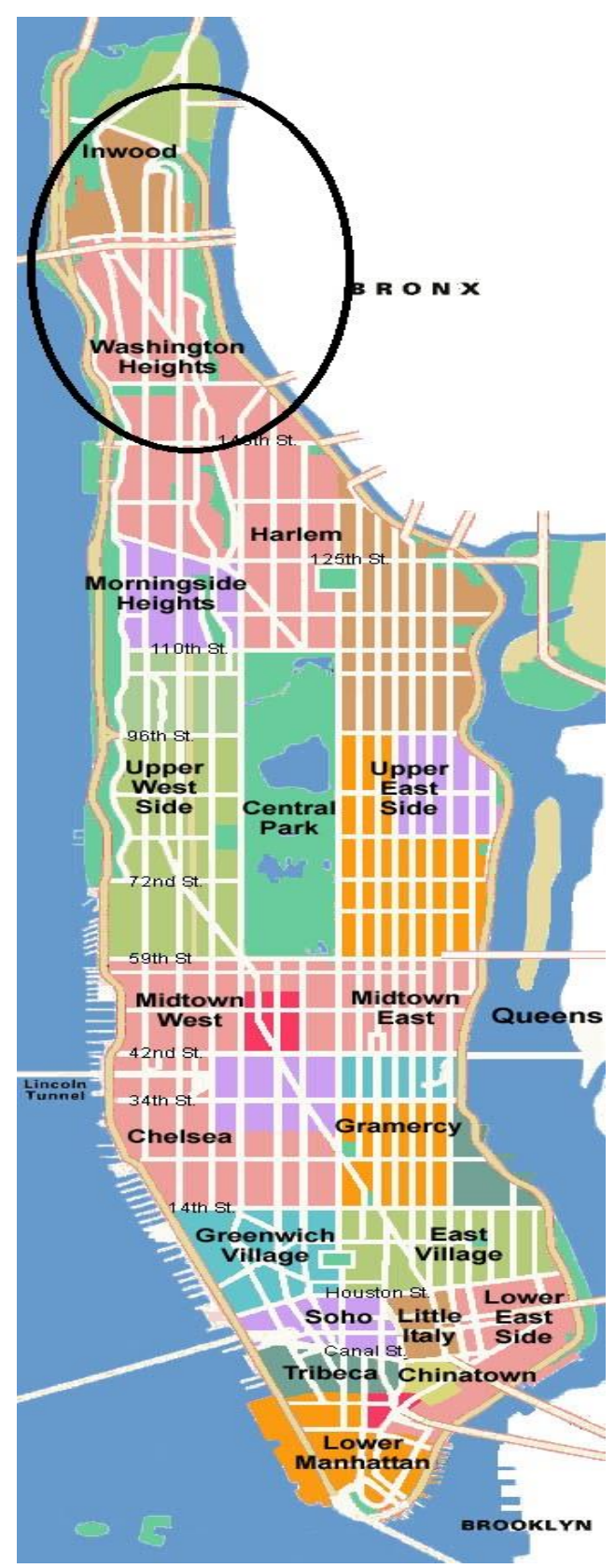

Fig. 14.3. NMIC Service Area 


\subsection{WEATHERIZATION AND THE MULTIFAMILY HOUSING SECTOR}

\section{Eligibility}

NMIC works with many varying building characteristics across Manhattan's residential building sector, including types of buildings, fuel type, metering type, and types of mechanical systems. However, they must adhere to DOE WAP guidance on inclusion criteria for a multifamily property to be eligible for Program weatherization services. If a building is deemed eligible, all units in the building receive costeffective measures, not just the units with income-eligible households. The following conditions must be met per DOE rules:

- A minimum of 66 percent of the dwelling units in the building must be occupied by families that meet the income requirement (as required under 10 CFR 440.22(b)(2)); or 50 percent if there are four or fewer units.

- Households must be income-eligible--below 60 percent of New York's state median income or 200 percent of poverty level (by household size).

- For a reasonable period of time after weatherization work has been completed, the eligible dwelling unit will not be subject to rent increases as a result of the weatherization (as required under 10 CFR 440.22(b)(3)(i)).

- No undue or excessive enhancement has occurred to the value of the dwelling unit (as required under 10 CFR 440.22(b)(3)(i)).

Tenant meetings are conducted as part of the NMIC weatherization process. NMIC will hold as many as three meetings at one building. NMIC income-certification staff members facilitate the tenant meetings. These staff members go door to door requesting eligibility information from the tenants and to educate them on the weatherization process. This is where tenant advocacy "bubbles up" into the weatherization program. This is not always done at other agencies. Unfortunately, this is where some buildings fall out of the process due to lack of building owner cooperation in setting up the meetings with tenants, and their buildings thus lose weatherization services. For NMIC, however, this has been a rare occurrence.

To streamline the process for certifying WAP income eligibility for multifamily buildings and properties, DOE and HUD have agreed to a Memorandum of Understanding (MOU) (See Exhibit 14.2). NMIC utilizes the HUD eligibility list, improving the efficiency of verifying income eligibility for buildings.

\section{Recruitment}

Prior to ARRA, NMIC had little need to engage in outreach or marketing efforts to recruit building owners for weatherization. According to Rieber, "They just came in." NMIC reports that information regarding weatherization and its benefits was shared by building owners through word of mouth communication, and through NMIC's involvement with active tenant associations. Prior to ARRA, NMIC was able to weatherize 9-15 multi-family buildings per year and was able to secure the work through this informal marketing. This social networking mechanism among building owners continued into the ARRA period. General agency marketing and the assistance of a city helpline that directs weatherization inquiries to NMIC helped NMIC secure partnerships with building owners. During the ARRA period, 2,044 units were weatherized and all ARRA grant money was spent. 


\section{The Pre-Audit}

NMIC requires a good-faith deposit of \$2000 as part of the building owner contribution prior to any work being completed. When the initial meeting with a building owner has taken place, and a good-faith deposit has been received, a pre-audit of the building is performed. Pre-audits include roof sketches, window counts, and basic heating-system information concerning pipes and boiler type. The superintendents or "supers" of the buildings are interviewed by the NMIC team to learn more about heatdistribution problems and other needs of the building. NMIC measures each unit to determine the optimal size of the boiler for heating the space and also interviews the tenants about heat distribution. NMIC reports that 90 percent of building owners follow through with weatherization after the pre-audit is conducted and that only 1 percent are "walk-aways" situations where NMIC walks away from a job for reasons of either cost-effectiveness or safety. The remaining 9 percent involve building owners walking away from the negotiations.

NMIC does not exclude buildings cited for Code $\mathrm{C}$ health and safety violations. Instead, the agency informs the building owner that the violations must be remediated before weatherization work can begin. For example, only after a pest infestation is mitigated can work commence. However, NMIC does assess the level of infestation to determine whether deferral is necessary, as the weatherization work itself (e.g., caulking around baseboards or installing door sweeps) will generally address minor infestations.

\section{The Audit}

The majority of building energy audits are conducted by the agency in house. For more complicated buildings, such as those with massive HVAC systems on the roof, or properties like West Beth (described in Exhibit 1), NMIC will subcontract out the energy audit work to the Association for Energy Affordability (AEA), a WAP technical service provider and Subgrantee that serves the Bronx (See Case Study on AEA).

The projected scope of work is based on a formula that measures the amount of energy saved vs. the cost of a given weatherization measure; this formula yields the cost-effectiveness of that measure. This is called the SIR. The SIR of the measure must be greater than 1.0; that is, the savings over the life of the measure must be greater than the investment.

\section{Building Owner Negotiations and Contribution}

Although WAP does not require building owners to contribute to major capital improvements completed for the building, NMIC typically requires owners to contribute at least 25 percent and may require up to 40 percent, depending on the audit, the scope of work, and negotiations with the building owners related to measures not supported by the audit without owner contribution. NMIC makes exceptions to the owner contribution requirements for non-profits with 501(c) 3 tax credit status, or low income co-ops that have no money to contribute. For example, the Department of Homeless Services owned a shelter in need of weatherization but could not afford to have the work done. NMIC did not require any contribution because the department had no funds. In that instance and in similar situations where there are no owner funds that can contribute to the "buy-down" of the major measures' cost in order for them to meet SIR, WAP dollars are restricted to the cost-effective measures identified in the energy audit only, usually resulting in a reduced scope of work. For this particular homeless shelter, NMIC installed some windows, but it could only install what the audit showed as cost-effective measures. NMIC reports not dealing with these situations very often. 


\section{Leveraging}

NMIC leverages its weatherization program dollars with utility money mostly secured through NYSERDA programs aimed at improving energy efficiency in multifamily buildings. NMIC started supplementing WAP dollars with utility ratepayer funds through a program called ULEEP (Utility Lowincome Electric Efficiency Program), funded by Con Edison. In 1997, NYSERDA took over the ratepayer fund. NMIC continues to leverage utility money through NYSERDA's Multifamily Performance Program (MPP) and uses Con Edison funds to install electric measures in both apartments and the common areas of multifamily buildings. NMIC plans to utilize MPP and Con Edison programs more extensively after the ARRA grant funding expires.

\section{Unit and Common Area Measures}

NMIC has two in-house crews and three workforce development interns. The crews perform most in-unit and common area (See Figure 14.4) work installing CFLs, low-flow shower heads, door sweeps, smoke alarms, covers for window air conditioners. In addition, NMIC can seal air leaks with using weatherstripping, caulking and spray-foam insulation.

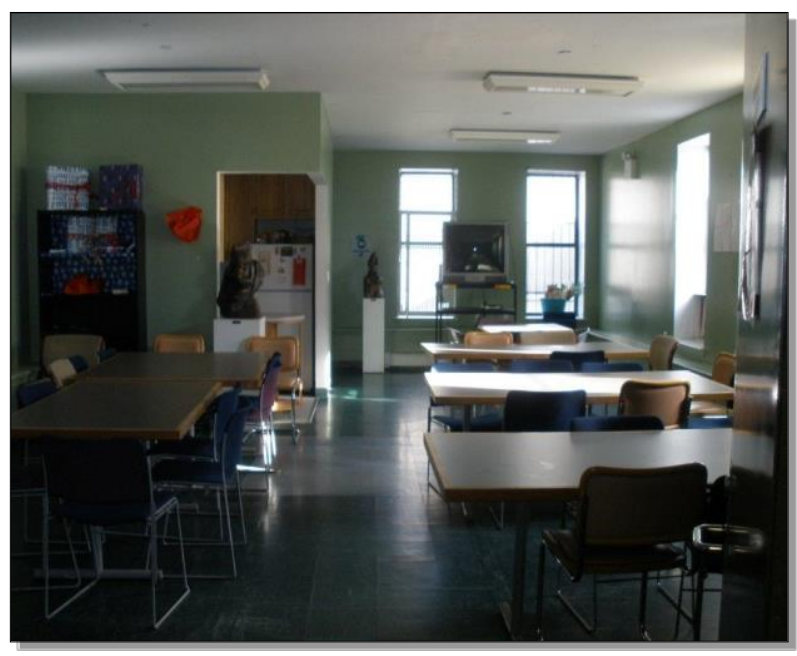

Fig. 14.4. Common Area in NMIC's Lead Safe House

Over the years, the crews have learned to identify and can often anticipate tenant needs and behaviors. For example, in HUD buildings with through-the-wall air-conditioning units, sleeves for the units are distributed to the tenants to reduce drafts. Crews have noticed that often, tenants do not have space to store the sleeves during the seasons when they are not in use. The crews now consider storage capacity for the sleeves while they are working in the unit and will identify alternative storage elsewhere in the building if necessary. Crew members appreciate the importance of tenant comfort and the lengths tenants will go to achieve control over the temperature within their units, and the impact this has on the efficiency of the building. 


\section{Major Measures}

In addition to the unit and general usage area measures installed by the in-house crew, NMIC subcontracts out for the cleaning, testing, and maintenance of equipment and for major measures including the:

- replacement of heating system equipment

- replacement of domestic water heating equipment

- replacement of windows

- insulation in walls and roof cavities

Weatherization services may also include other energy-related improvements, such as water heater repair/replacement, roof repair/replacement, chimney repairs, lighting fixture replacement, ventilation systems, heating distribution system replacement, refrigerator replacement, installation of GFCI outlets, and electrical service upgrades.

\section{Training and Education}

NMIC believes that education is key to maximizing the energy efficiency of a building. The crew chiefs and heating contractors train superintendents, ("supers"), on operating the newly installed heating systems (See Figure 14.5). Building owners are required to pay for supers to attend a five-day training offered by the Association for Energy Affordability. NMIC staff members believe DOE should consider superintendent education as an allowable expense. In fact, in NMIC's opinion, there should be a combination of super-plus-tenant education where supers are schooled in basic building science and tenants are educated on how their behaviors impact the building's efficiency and comfort. There is an observed "perceived comfort issue," which can lead to tenants overheating, or "cooking" the building. Tenants may receive education in steam heated buildings on the operation of their radiators and the impacts of opening windows in overheated buildings. Addressing heating system issues, engaging in dialogue with tenants, supers, managers and building owners, and education are all components of NMIC's approach to achieving both energy savings potential and improved tenant comfort.

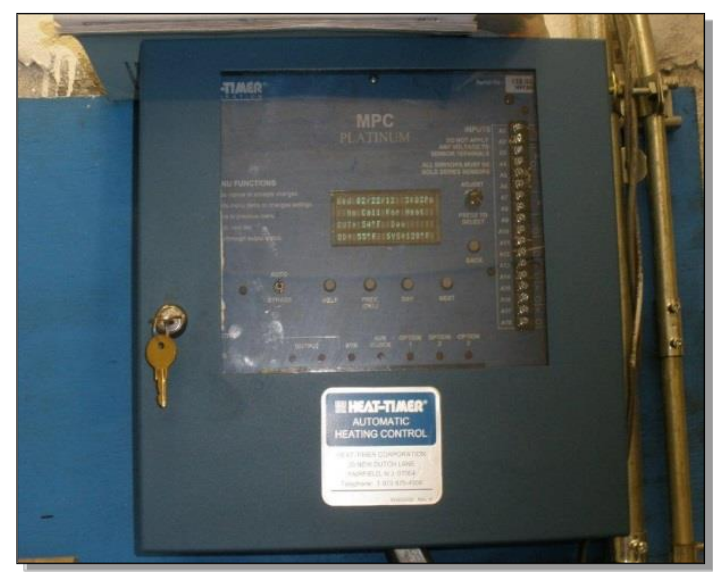

Fig. 14.5. Heating System Controls 
NMIC makes it a point to engage both tenants and staff in a discussion on the selection of measures for a given apartment. For example, they explain to tenants why they are replacing showerheads as a measure to conserve water and to reduce energy consumption related to heating it. There are "layers to this." NMIC believes that in order to achieve maximum savings in a building, the human factors related to superintendents' knowledge and skill, as well as tenant behavior, must not only be considered but taken seriously.

\section{Accrual of Benefits to the Tenant}

By law, tenants are required to be the primary beneficiaries of the Weatherization Assistance Program. In recognizing that there are instances in which tenants do not pay directly for the energy they consume, DOE has issued guidance on ways that WAP Subgrantee can ensure accrual of benefits to the tenant. General assertions of potential benefits are not adequate. The following is a list of acceptable examples of tenant benefits under DOE WAP guidance:

- Longer-term preservation of the property as affordable housing;

- Continuation of protection against rent increases beyond that required under the WAP regulations (10 CFR 440.22(b)(3)(ii));

- Investment of the energy savings in facilities or services that offer measurable direct benefits to tenants;

- Investment of the energy savings from the weatherization work in specific health and safety improvements with measurable benefits to tenants;

- Improvements to heat and hot water distribution, as well as ventilation, to improve the comfort of residents; and

- Establishment of a shared savings program.

In the spirit consistent with NMIC's commitment to the preservation of affordable housing, the agency adheres to the policy encouraging protection against rent increases after weatherization has taken place. The tradeoff for the building owner is a more energy-efficient building, resulting in energy cost savings and NYC tax credits. The rent-protection policy limits the number of tenants, who could otherwise face rent increases as a result of major capital improvements completed by the building owner without WAP involvement. The only reported instance of rent increases appear to occur in the case of lease renewals, when rent is allowed to be raised by a rent guidance board. This issue appears to be beyond the control of WAP or NMIC.

Health and safety measures allowed include the installation of $\mathrm{CO}$ and smoke detectors, testing ovens and heating appliances for $\mathrm{CO}$ and gas leaks, pest management as a result of air-sealing measures, cleaning ducts and repair ventilators in the ventilation systems and improved lighting in common areas. These measures are intended to improve health and quality of living standards for tenants.

The Program also supports the mission of the agency to promote secure and violence-free environments for the inhabitants. In a recent AEA documentary capturing the impact of the Program on tenants, one of the building occupants described the stress and pressure of residing in an unsafe and unhealthy apartment building before weatherization. She stated she felt as though she was "pressed on," and that 
weatherization created a safe living space relieving that pressing sensation. Ameliorating the physiological and psychological symptoms of oppression and poverty through work like weatherization is a benefit that is often overlooked but is important to the residents.

\subsection{BARRIERS TO WEATHERIZING THE MULTIFAMILY HOUSING SECTOR IN NYC}

NMIC's weatherization program staff identified on-going barriers to weatherizing eligible buildings in their service territory, as well as barriers to the weatherization of multifamily buildings in general. Some, such as internal bureaucratic problems endemic to nonprofits and supportive housing administrations, are beyond NMIC's control. However, there are also some WAP rules and guidance that can impede a Subgrantee's ability to achieve the goals of the program within this housing sector. For example, NMIC staff are not supposed to revisit buildings after work has been completed, but often need to go back to a building to "tweak" settings on heating equipment; sometimes they even drive by a building in the winter, checking for open windows on the upper floors that would indicate problems with heat distribution. Although they do this with the blessing of their state monitors, they believe WAP should allow them to observe seasonal variation so they can check on their work. It makes no sense, in their opinion, to install a sophisticated heating system in the middle of the summer and then walk away without returning to assess performance in the following seasons.

A WAP rule preventing fuel switching ${ }^{40}$ (for example from oil to natural gas) limits both NMIC and the building owners in the area of cost performance. Building owners have expressed a desire to convert to natural gas because it is cheaper than fuel oil, but the WAP rules do not allow this.

Deutsche Bank Americas Foundation Study; "Recognizing the Benefits of Energy Efficiency in Multifamily Underwriting"

In 2011, NMIC participated in a research study initiated by Deutsche Bank Americas Foundation. ${ }^{41}$ The study sought to determine the feasibility and potential success for the financial industry to invest in energy-efficiency retrofits in multifamily buildings in New York City. To encourage private capital lending in an industry dominated, but limited by, public subsidies, stakeholders in the energy efficiency industry furnished data to support the claim that energy savings pay for investments, and identified ideal strategies and conditions for achieving projected savings. It is unclear whether the results from this study will have an impact on NMIC, which deals mostly with publicly subsidized buildings as opposed to privately owned buildings. Market transformation has yet to occur, and as NMIC had only recently starting exploring the fee-for-service market. NMIC staff did report that the study validated the worth of their work.

\subsection{THE AMERICAN RECOVERY AND REINVESTMENT ACT (ARRA) AND WAP}

During the ARRA grant period, NMIC's Weatherization Program was allocated \$14.4 million to weatherize 2,044 units between PY 2009 and 2012. The agency exceeded its charge, completing 2,853 units. New York State's total for the period was 62,143 units with 86 percent of those units completed in multifamily buildings with five or more units. Before the ARRA grant, 3,000 units were on the waiting list for NMIC's weatherization program. During ARRA, the waiting list shrank to 1,200 units.

\footnotetext{
40 "5.11 FUEL SWITCHING: WAP does not permit the general practice of non-renewable fuel switching when replacing furnaces/appliances. However, DOE does allow the changing or converting of a furnace/appliance using one fuel source to another on a limited, case-by-case basis only." (2010, WPN 11-1, pg. 22)

${ }^{41}$ https://www.db.com/usa/content/en/ee_in_multifamily_underwriting.html
} 
Prior to ARRA, NMIC had employed six full-time equivalent staff to support its weatherization program, but during ARRA, the program was able to support 12 full-time staff. Four persons were added to the inhouse crew, one was added to assist with tenant income verification, and one person was added to support compliance with Davis-Bacon regulations. The plan for post-ARRA funding and a 40 percent cut in their base contract for regular program funding was to only let go of the workforce development interns. This anticipated reduction in staff was observed across the WAP network nationwide.

\section{Davis-Bacon}

According to NMIC representatives, Davis-Bacon reporting requirements had a crippling effect on their weatherization program; they believe only the field staff benefitted. A new position was needed to ensure Davis-Bacon compliance, and the entire accounting and payroll system required change. In addition, waiting for Davis-Bacon rules to flow down from the federal office delayed weatherization work for approximately seven months.

\subsection{BUILDING OWNER DEBRIEFING}

ORNL WAP evaluation researchers met with three multifamily building owners-Lee Mosier, David Freeman and Paul Salib. Together, these business partners have weatherized three of their multifamily buildings. They were initially referred to NMIC through NYSERDA in 2010. Salib viewed WAP as an opportunity to save money by weatherizing his buildings and thus being free to invest the saved capital in other areas, thereby creating a better environment for tenants while improving the building. For him, the 25-30 percent owner contribution was worth the investment; he reported that the investments pay off in two to five years, depending on which major measures are installed. The owners reported that after a building is purchased, they complete the building's to-do list with the following items:

1) Installing security cameras as a signal to tenants that the new owner(s) wants to create a safer living space for those residing in the building (See Figure 14.6).

2) Dealing with violations; buildings can have hundreds of city health and safety violations. A violation team goes through a building unit-by-unit to address the violations.

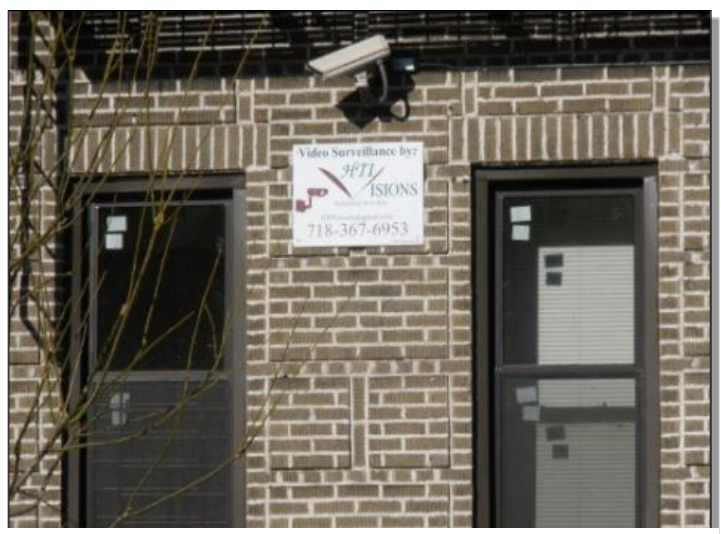

Fig. 14.6. Camera and Surveillance System 
3) Signing up all buildings with the local District Attorney's office which has a program, in which a building owner can give an empty apartment to the police department to work out of, increasing safety for building residents.

4) Fire-escape repairs.

5) Changing boilers to run on natural gas if necessary; Salib reported a 35 percent energy savings and reports if there was no fuel switching the projected savings were at 25 percent.

The three building owners described their experience with one of the properties they had purchased and eventually weatherized. The Sherman Avenue property (93 units; 56,000 square feet) was bought in fairly poor condition. They reported that there was a time when investors would buy buildings looking to make money. What resulted was a property with numerous city violations and buildings infested with pests and drug dealers due to the investors having little interest in managing the property. After dealing with the building's city violations and crime issues, the new owners looked to NMIC to help. Weatherization involved a comprehensive scope of work, which included air sealing in the apartments, a new boiler, new refrigerators, and installation of pipe insulation, roof insulation, and common-area lighting. Salib reported the test-in and test-out numbers are proving "tremendous" energy saving results, noting that he is now able to put that capital into other places, such as the revamping of common areas and the installation of an elaborate camera and security system. On the wish list: solar water heating technology.

In addition to seeking energy savings, the building owners reported interest in the quality of life of their tenants. They reported viewing the footage from AEA's weatherization film with tenant testimonials, and reported that it was "eye-opening" to hear the tenant story. Prior to weatherization, tenants reported not being able to breathe in their units, and now they can. The owners also opted to install temperature sensors in the top floor to prevent over-heating.

The owners on this day reported being very satisfied with the work completed. They reported achieved energy savings and the ability to re-invest in the building for the benefit of the property, and for its tenants. They reported NMIC staff went "above and beyond" to ensure quality work was completed.

\subsection{SITE VISITS}

\section{Independence House}

ORNL conducted a site visit to Independence House, a weatherized building in the Washington Heights community (See Figure 14.7). The building is owned by an organization called Assistance for Case Management and Housing (ACMH). The building consists of three floors with a total of 24 residential units. There is one common kitchen and six shared bathrooms. NMIC installed CO and smoke detectors in all units, CFLs in common areas, and provided insulation blankets for the window AC units, which hadpoor "wings." Before weatherization, the building had a cast-iron atmospheric boiler, which was replaced with a high-efficiency condensing boiler. While the unit was being switched out, a temporary boiler was brought in with hoses run from a truck outside the building. Weatherization also involved duct sealing and installation of a circulating domestic water heating system. 


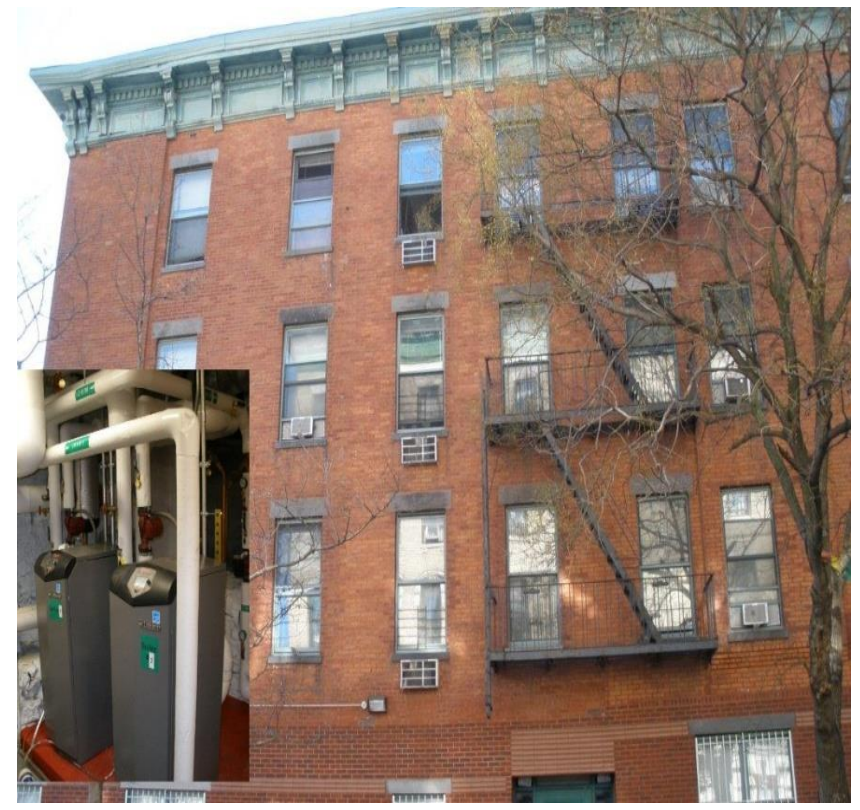

Fig. 14.7. Independence House

\section{NMIC's Lead Safe House and Renewable Energy}

NMIC asserts that the children most at risk for exposure to lead [in its territory] reside in the Washington Heights and Inwood communities. For this reason, NMIC operates a Lead Safe House program for families with children with high lead levels. One component of this program is providing temporary shelter to families while lead remediation work is conducted in their apartments. There are a total of 15 housing units in the building that NMIC operates for this purpose (See Figure 14.8). Some of these are rented out at market rates to offset the costs of operating the building.

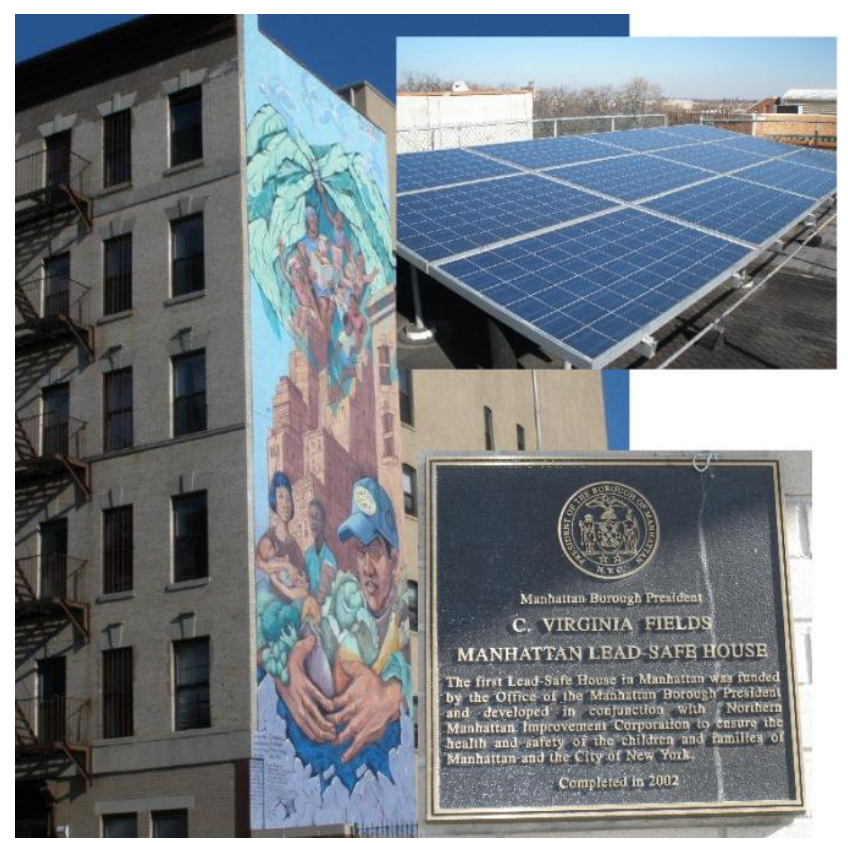

Fig. 14.8. C. Virginia Fields Manhattan Lead Safe House 
To further offset energy related costs of the lead-safe shelter building, NMIC has partnered with Morgan Stanley, a financial advising corporation, seeking tax credits.

Morgan Stanley donated money for the installation of a photo-voltaic system that supplies 4.7 Kilowatts of energy. The system provides for the electrical needs of the common spaces, including the meeting room, elevators, hall lighting, and electrical heating. Developing these partnerships and projects targeting the reduction of energy consumption in multifamily buildings is further testament to this agency's commitment to the preservation of affordable housing and the families that they house.

\subsection{EXHIBITS}

\subsection{Westbeth}

During ARRA, NMIC completed weatherization work at Westbeth, an artist community managed by a nonprofit with an old HUD mortgage. NMIC titled this weatherization job the "Most Complicated Weatherization Case in New York." The property contained nine structures all connected by underground heating pipes. The structures had old steam-heating units that were replaced by NMIC with a highefficiency boiler. To complicate this already complex job, Westbeth is a multi-use property supporting a synagogue, and numerous art studios (See Figure 14.9). Because WAP dollars can only be spent on residential areas of a building, the property owners contributed $\$ 250,000$ and MPP funding was also secured from NYSERDA. This project is a demonstration of how a multi-use property can be weatherized using both WAP and leveraged funding.

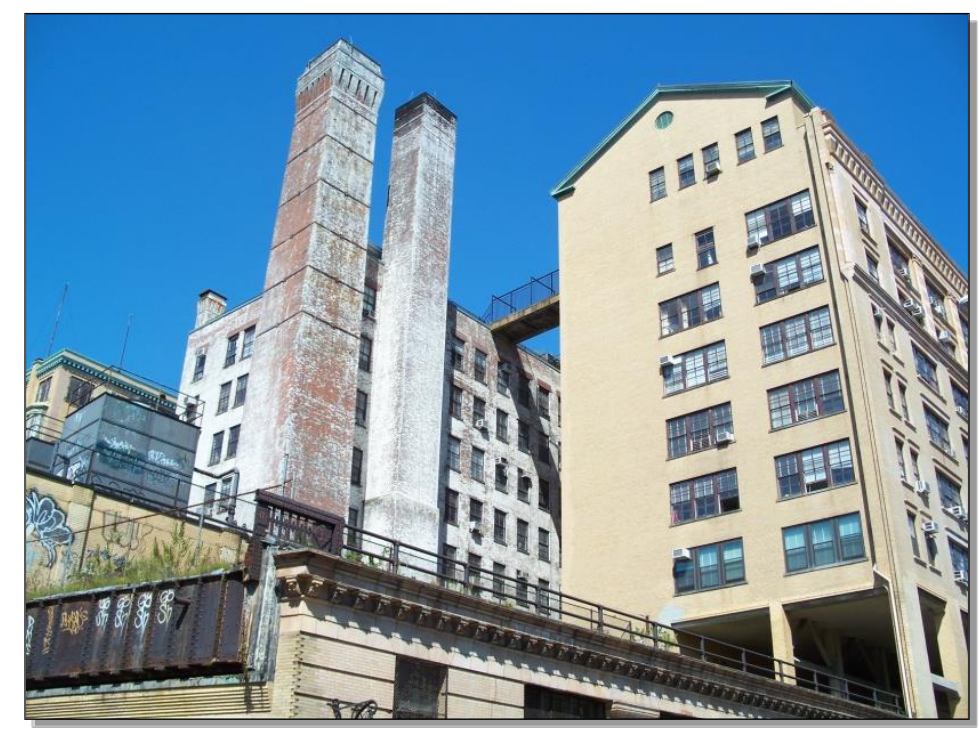

Fig. 14.9. Westbeth

\subsection{The DOE and HUD Memorandum of Understanding (MOU)}

The partnership between DOE and HUD was announced on February 27, 2009, outlining a plan to streamline and stimulate home energy conservation through weatherization services in public and assisted housing. The goal was to create a more affordable housing stock for low-income populations, and to spur job growth within the sectors of home energy efficiency. A MOU was created in May of the same year with a list of commitments consistent with the mission of both federal agencies. Highlighted tasks of the MOU included the following actions, which have since been accomplished: 
- HUD provided DOE with a list of HUD Qualified Housing projects and Low-Income Housing Tax Credit (LIHTC) projects meeting WAP eligibility criteria for multifamily housing to reduce the burden of income verification and eligibility on local weatherization agencies.

- HUD and DOE provided guidance to all entities impacted by the partnership, educating stakeholders on the theoretical and logistical implications of aligning resources.

- HUD and DOE developed a system for training and technical assistance to assure successful implementation and execution of the program

- HUD and DOE will evaluate the process and outcomes of the partnership to inform future policy, explore other innovative ways to partner within common missions, and identify approaches for future leveraging initiatives.

A Final Rule, effective February 24, 2010, was published on January 25, 2010 in Vol. 75, No. 15, page 3847 of the Federal Register, stating that under Title 10 CFR, Part 440:

"The U.S. Department of Energy (DOE) is amending the eligibility provisions applicable to multi-unit buildings under the Weatherization Assistance Program for Low-Income Persons. As a result of today's final rule, if a multi-unit building is under an assisted or public housing program and is identified by the U.S. Department of Housing and Urban Development (HUD), and included on a list published by DOE, that building will meet certain income eligibility requirements, and will also satisfy one or both of the procedural requirements to protect against rent increases and undue or excessive enhancement of the weatherized building, as indicated by the list, under the Weatherization Assistance Program without the need for further evaluation or verification."

The Final Rule provides details about these and additional requirements relating to the benefits that must accrue primarily to the occupants of the rental unit.

Neither states nor local weatherization agencies are required or expected to set aside weatherization funds for public or assisted housing. This determination is left to the discretion of the state, which may or may not then leave to the discretion of the Subgrantee. States that have not set aside funds specific for this project allow local weatherization agencies to determine approval for public or assisted multifamily housing retrofits based on timing and available funds or resources. States may also set aside funds for state assisted public housing, but not for HUD-assisted public housing.

HUD bears the burden of the financing and furnishing of three lists supplying data on public or assisted multifamily properties, buildings, and projects meeting WAP income eligibility requirements. HUD is responsible for verifying eligibility and DOE is then responsible for publishing the list. It is understood that if a building, property or project is on the list, it is eligible for WAP and no further verification of eligibility is required on the part of DOE, Grantees or Subgrantees. DOE stated intentions to support the HUD and DOE partnership aimed at streamlining the weatherization process for this housing stock by adhering to the Final Rule published in the Federal Register.

HUD excluded the following public or assisted multifamily buildings from the lists:

- Buildings where income could not be verified as a result of non-reporting.

- Buildings that did not meet income eligibility. 
- Indian Housing, as HUD does not collect data on housing type or occupant income. These tasks are delegated to the Indian Housing authorities.

Excluded buildings or properties may still be eligible for weatherization services but require income verification by the local weatherization agency. 



\section{COMMUNITY ACTION - MINOT, NORTH DAKOTA}

\subsection{BACKGROUND}

CAP-Minot Region administers the Weatherization Assistance Program (WAP) to seven counties and one tribal reservation in north central North Dakota (See Figure 15.1). This high-performing WAP agency was recommended for inclusion in ORNL's National Evaluation of WAP Case Study task for their highquality work and their attention to mobile homes in a climate with temperatures ranging from below $0^{0} \mathrm{~F}$ in the winter to up to $100^{\circ} \mathrm{F}$ in the summer.

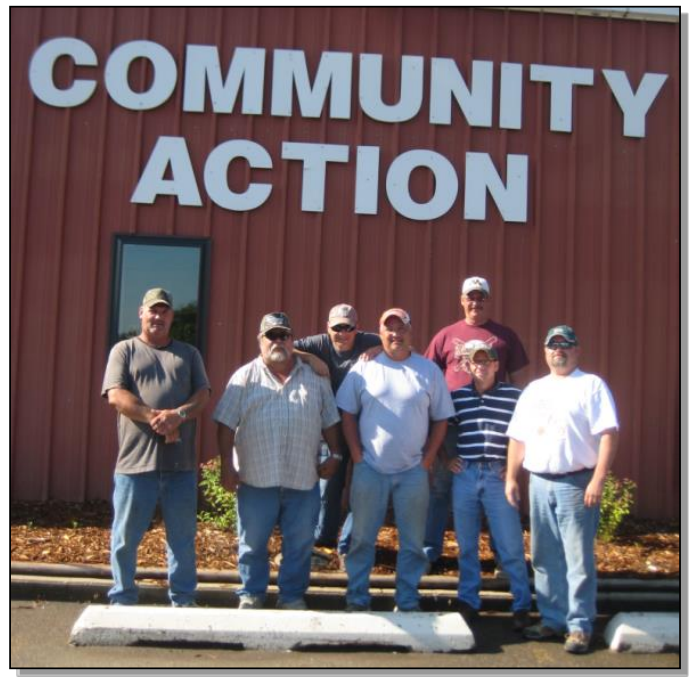

Fig. 15.1. CAP-Minot Region

CAP-Minot Region was contacted by ORNL during the summer of 2011 in efforts to coordinate the case study visit. However, the request came at a time when this CAP's service territory had suffered massive flooding of the Souris River Valley, displacing nearly 12,000 people and creating \$1 billion in local damage.

Over the course of the next year, this small CAP and its staff would personally and professionally deal with the temporary homelessness of their agency, as well as personal and community disaster relief efforts. In addition, much of the WAP eligible housing stock was lost, as numerous mobile home parks were devastated, their residences deemed structurally unsound or unusable because of water damage. Many income eligible persons were displaced in the flood. Also observed was a reduction in affordable housing due to competition for adequate living space after the flood and competition with the influx of employees migrating to the area to support the oil-fracking boom in a neighboring town.

The case study visit to this agency was eventually conducted one year after the flood and at the peak of the oil-fracking boom in July of 2012. Profile 3 in this case study highlights the flood's impact on the agency's operation of weatherization services and the WAP-eligible population. It is the story of how the people staffing the Minot program responded to the crisis. It is the story they chose to tell and underlines their commitment to the Program and the dedicated work performed to fulfill a mission focused on the vulnerable in their community in times of crisis and beyond. 


\subsection{PHILOSOPHY AND APPROACH}

The CAP-Minot Region staff strives to provide energy conservation services to low-income homeowners and renters in order to make their homes more energy-efficient (See Figure 15.2). The program helps to increase energy-efficiency and reduce heating bills by concentrating on the problems of heat loss and air infiltration that are most endemic in this climate. ${ }^{42}$

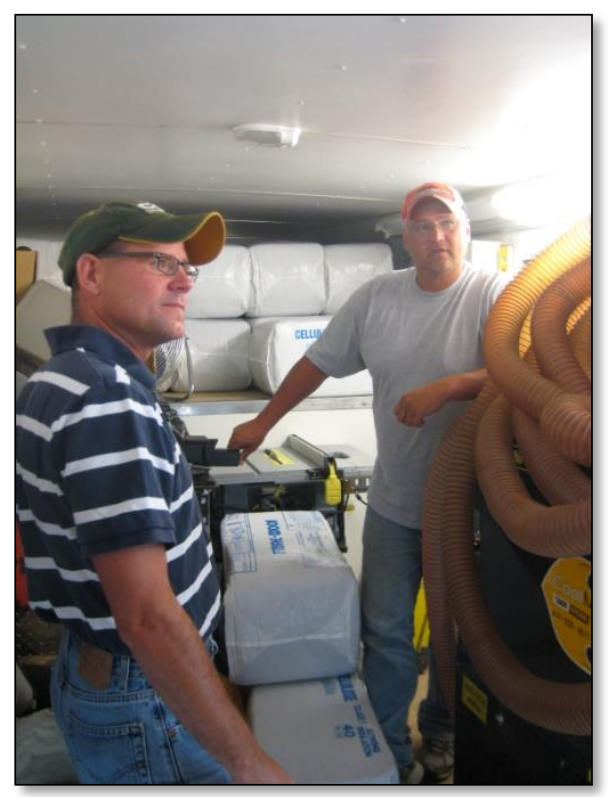

Fig. 15.2. Weatherization Staff and Supplies

Weatherization Delivery

CAP -Minot Region operates three home services programs;

- Weatherization Assistance Program

- Emergency furnace and water heater repair and replacement funded through LIHEAP

- Infrared Camera

The weatherization staff includes the director of weatherization and six crew members with a range of 1030 years experience. At the peak of ARRA and pre-flood, the weatherization program supported two fiveperson crews. They went down to one four-person crew with two foremen shortly before the end of ARRA. A total of 423 units were weatherized during ARRA. This is a testament to the dedication of a crew and its leaders at both Program and agency levels dealing with the impacts of $b$ a devastating flood and a shift in demographics. This dramatic shift in demographics was a result of both the flood, and from the influx of workers that moved to Minot and the surrounding area during the oil boom. A shift in socioeconomic status was also observed due to additional income from the sale of oil rights on private land. Agency staff reported that they hardly weatherize west of Minot anymore. There is "too much oil money out there now. That combined with a great wheat crop means less households are eligible for

\footnotetext{
${ }^{42}$ http://www.capminotregion.org/programs/home-services
} 
weatherization." Weatherization services are provided to income-eligible households in Burke, Bottineau, McHenry, Mountrail, Pierce, Renville, and Ward counties. One month out of the year, CAP-Minot Region designated tribal money for weatherization of homes on Berthold Indian Reservation.

\section{Weatherization Approach}

The CAP-Minot Region weatherization program operates a 4-days-per-week/10-hours-per-day work schedule with crew members returning to the warehouse at the end of each day (See Figure 15.3). Most of the crew goes out on every install. The team includes two "estimators" or auditors. North Dakota devised an audit tool, WEXOR, which is DOE-approved and which prioritizes measures according to the highest payback in terms of SIR. The estimator conducts the audit and passes the work scope on for the install. Both the estimator and the crew recognize the importance of effective communication between the parties to ensure the job is completed as the estimator intended. However, there are occasions where the estimator might have missed something, such as the time when an estimator did not notice a pig being fattened in the basement for a holiday feast. In this case, the estimator was asked to explain how he had missed noting the pig. And, as once happened, on the chance that an estimator finds a hole in the bathroom wall large enough for a horse outside to lean inside to drink out of the bathtub, the crew and crew foreman are trained and empowered to identify and fix the problem. If there is a question about the best course of action, Bruce Hagan and Cal Steiner are available to consult at the state level.

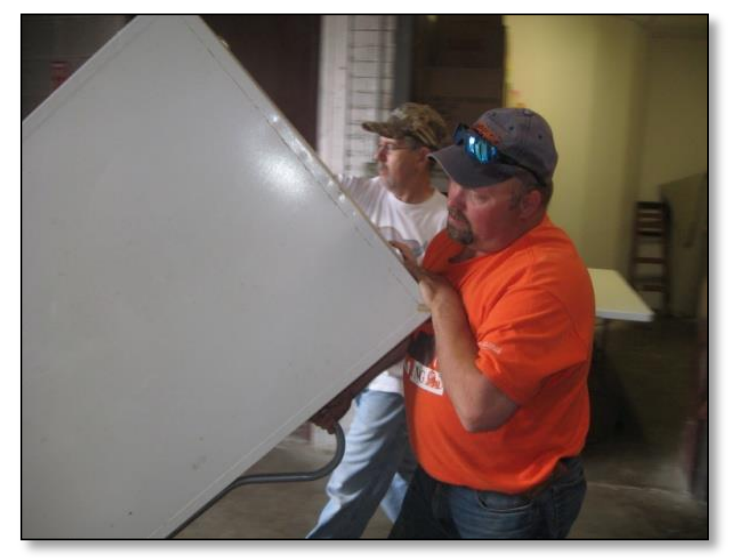

Fig. 15.3. Weatherization Staff Prepare for Work

The first task when a crew arrives on site at a mobile home, prior to the installation of insulation, is to seal the heating registers inside. The crew sends a flashlight/mirror down the heat supply duct runs to make sure there are no holes, as fiberglass from insulating the belly will go into ducts if holes are present. Then the crew foreman sends crewmen (at this time there were no female crew members) out - six men, two on the "belly" or base of the house, two on the walls, and two in the attic - to apply the measures prescribed for each area. Major measures might include insulation, air sealing, and furnace replacement (increasing the furnace efficiency from 65 percent to 95 percent). The program will switch the fuel type of the furnace from oil to propane only if they can prove the payback will be adequate.

During the case study visit, all crew and foremen were observed to be of great physical stature. When they were asked what they did without a small man or woman on their crew, they said they have no problem getting into tight spaces and that they win the tug of war at the state get-together every year. 


\section{Health and Safety}

The weatherization team adheres to lead-safe practice both by testing for lead based paint and assuming there is lead; normally if it is an old farmhouse built prior to 1978, it is assumed there is lead paint and they proceed accordingly. They distribute information on the risks of lead and radon in homes, although it was reported that not very many people seem to read the materials.

\section{Energy Education}

In the past the agency had additional funds to facilitate energy education with the occupants. The person who had delivered the education provided information on cleaning filters, thermostat settings, and water heater temperature. Now they attempt to educate the occupant during the audit and installation phases on ways they can conserve energy. They also attempt to talk to clients about what is or is not included in the scope of the work. For example, they might explain that they don't typically replace windows because window replacements do not usually meet DOE cost-effectiveness standards.

\section{Leveraging}

CAP-Minot Region received \$0 from DOE for WAP for FY 2012. They had a small amount of funding banked from previous years, as well as LIHEAP funding that they planned to use to support the Program. At the time of this case study visit this agency was attempting to secure additional leveraged dollars. Minimal funding from utilities is available in this region and the agency began to seek out other sources. They were in the process of drafting a proposal requesting funding from the state, which saw a \$2-3 billion surplus as a result of the shale oil industry.

\section{Training}

Members of the weatherization staff report the trainings offered at the state level to be the most beneficial. They believe they learn more from those working within the North Dakota climate and housing stock. North Dakota has a core group of people, including weatherization expert, Cal Steiner, who have been with the Program for decades and have experience in the field, in management and at the agency level in training. Weatherization Director Meyer reports the use of training funds for On the Job Training (OJT) and finds value in mentoring in the field.

\section{Innovativeness}

This WAP agency continues the mission set by Cal Steiner to improve the energy efficiency and techniques for weatherizing the mobile home housing stock in North Dakota. Cal Steiner has over 33 years of experience working in the weatherization field in a wide range of roles from crew worker to trainer. A pioneer in the early movement in improving the weatherization of mobile homes, he continues to conduct trainings nationally on mobile home weatherization, crew motivation, lead-safe weatherization and crew development. ${ }^{43}$

When referring to Cal Steiner, Weatherization Director John Meyer stated that he had "never met anyone so dedicated to what they do. He researched and developed methods of blowing in insulation from the top of a mobile home. He [Cal] did a lot of research and took a lot of chances." However, Meyer did state that although Cal knows what to do, his guys in the field know quite a bit as well, and that it can be "fun to argue with Cal." It was reported that Cal is not afraid to try anything and trusts the WAP agencies and their crews to find the right solution and refrains from imposing mandates from the state.

\footnotetext{
${ }^{43}$ http://www.betterbuildingsil.org/bio.php?personid=390
} 


\section{Site Visit: "Nice and Warm"}

ORNL visited a mobile home in a rural county outside of Minot (See Figure 15.4). Weatherization Director Meyer informed us he had set out to convince the occupant, an acquaintance of his who suffers from Parkinson's disease, to apply for WAP knowing the impact weatherization would have on the mobile home and its occupant's comfort. The work scope consisted of insulating the walls (by taking a strip of siding off the house); blowing insulation into the attic from the gable ends; blowing insulation into the belly; and replacing an exterior door with a new steel door. The weatherization took two days. The occupant was not present at the time of the site visit, but left the following letter to be read by the ORNL evaluation team visiting his home in his absence:

"Minot Community Action,

Thanks for all you have done for me. John and his men worked long and hard days. My house was nice and warm all winter. The men that did my house were nice and neat. They cleaned up after themselves when they were done. Tell everyone thanks."

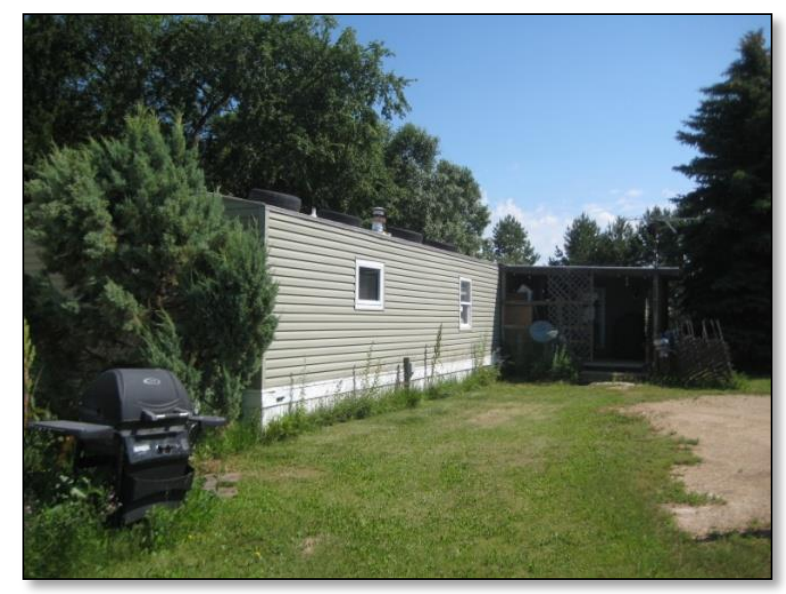

Fig. 15.4. CAP-Minot Region Weatherized

Mobile Home

\subsection{THE FLOODING OF THE SOURIS (MOUSE) RIVER}

The story this agency wanted to tell was evident from the moment they were first engaged.

Weatherization Director John Meyer was eager to share the agency's impact and response to the flood, and to the importance of having a skilled and dedicated crew already at the ready. An interview with these crew and crew foremen was conducted on site at the agency warehouse and has greatly contributed to the body of this report. Members of the CAP-Minot Region weatherization team provided discussion on their delivery of WAP, suggestions for improvements, and their personal dedication to the mission of the Program.

\section{The Flooding of the Souris River Flood Plain}

The Souris River has three dams. Two are located in the US and are managed by the US Army Corps of Engineers. The other is in Canada, 55 miles north of Minot. Before June 2011, all three dams were operating at record high (but stable) water levels until the lake in Canada, where the first dam is located, received nine inches of rain. The Canadians had no choice but to let the water go from the dam, knowing the impact that the high waters would undoubtedly have on the lower two dams and the surrounding flood plain (See Figure 15.5). Lake Darling, where the third dam is located, eventually was receiving water flowing at 27,000 cubic feet/second. 


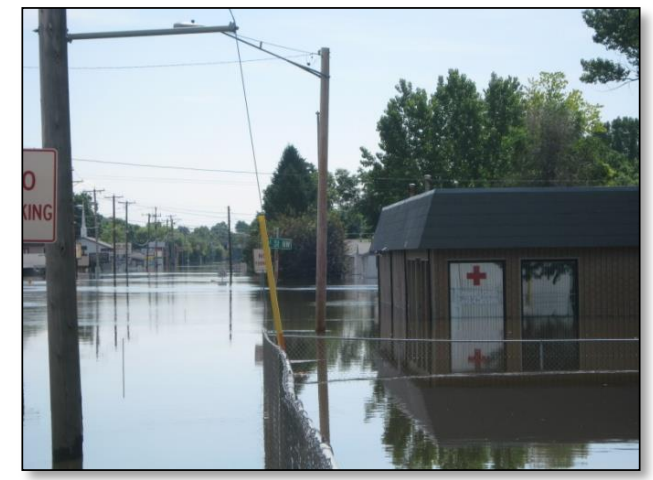

Fig. 15.5. The Flooding of the Souris River in Minot

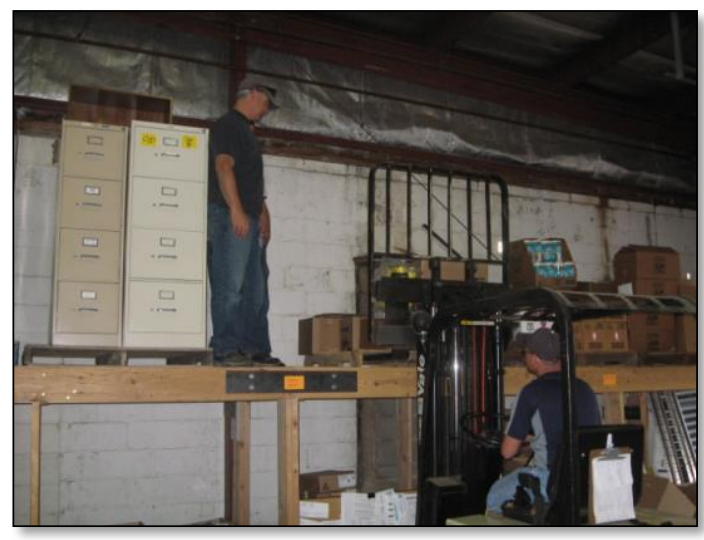

Fig. 15.6. Weatherization Staff Preparing for the Flood

When it was realized that the rushing waters of Lake Darling would be let go into the Souris River, the Mayor of Minot employed an evacuation plan. To ensure that everyone evacuated, he went on TV to warn, "The valley is going to be a lake." It was not a debatable point.

CAP-Minot Region agency personnel rushed to move everything of absolute importance either to a different location above the valley or to the upper shelves of the warehouse in hopes that it would be out of the water's reach (See Figure 15.6). Weatherization equipment, materials and files were moved. The agency staff prepared for a destruction that would impact both their professional and personal lives. The water was let out of Lake Darling over the course of three weeks. Four thousand homes were damaged, 12,000 people were displaced, and several schools, parks, and a zoo were destroyed. The community sustained $\$ 1$ billion in damages. However, there were no human casualties.

\section{Disaster Response}

The CAP-Minot Region immediately assessed the immediate community's need for emergency food assistance. For two months they worked out of a local middle school and then for four months out of a bank (See Figure 15.7). They communicated with clients via cell phones as their agency office had also been within the flood plain. They worked with local food pantries to collect and distribute food.

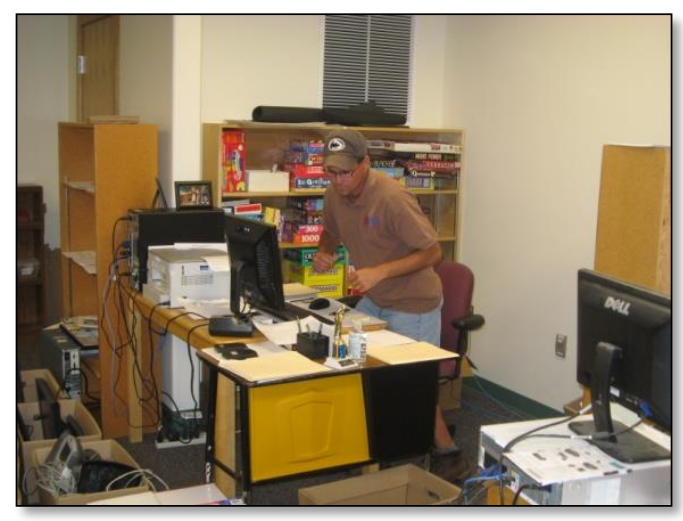

Fig. 15.7. Operating the Program from off site 
The flood dumped 40 inches of water into the weatherization workshop and 7 feet of water into the lower floor of the building housing all other CAP program offices, but the weatherization staff missed only 3-4 days of work after the flood and spent the next 3-4 months operating off site. One of the crew members had lost his home, and many others had close family members and friends who had lost theirs. John Meyer reported, "These guys were showing up to work and then going home to work again on their own homes or their family's homes."

Because there was only one bypass road to avoid the floodwaters, it took crew members an average of 2.5 hours per day to get to work. For nearly five weeks, most of the crew had to leave at 4:30 am to get to work by 7:30 am. They referred to themselves as "gypsies" roving around the outskirts of Minot weatherizing homes in a housing queue unaffected by the flood. They saw only a slight drop in production. Subcontractors continued to do work for them, but they were busy with other jobs as well. In addition, Weatherization Director Meyer stated that Davis Bacon really slowed down the agency's weatherization production. "It was hard enough to find contractors due to the flood in Minot and resulting need, most of them wanted nothing to do with Davis Bacon."

When the water finally receded enough for staff to get into the warehouse for clean-up (See Figures 15.815.10), the staff surveyed the damage, and immediately set to work. As a result of their dedicated efforts in preparing for the flood, they lost only $\$ 5000$ worth of inventory. All client files were saved.

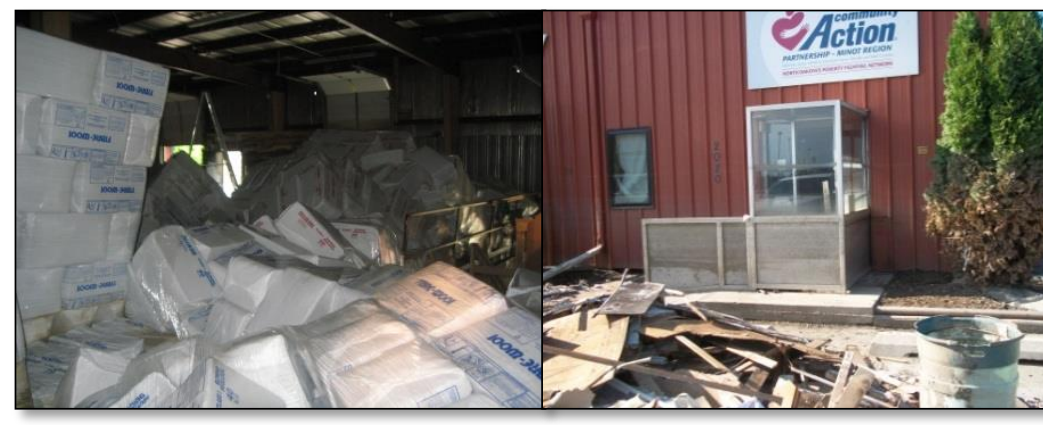

Fig. 15.8. CAP-Minot Region Office Post Flood
Fig. 15.9. Weatherization Warehouse Flooded

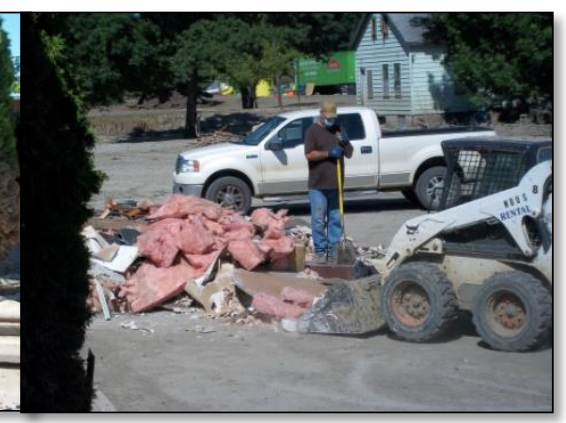

Fig. 15.10. Weatherization Staff Clean Up

By August, the flood waters had receded, and the community was busy repairing damage and preparing for the winter ahead. In Minot, snow can come in October. The community had to work fast to repair and rebuild. But, Minot and its surrounding area had changed. Many people who evacuated never returned. Only 10 percent of affected homes had flood insurance. Five mobile home parks which housed past, current and potential future work for this Program were completely lost. For an agency that generally works with the mobile home housing stock, this impact was severe.

Additionally, the oldest part of town is located in the valley, where the majority of the affordable housing stock and the Program-eligible population were housed and where the flood settled (See Figure 15.11). Because of the DOE's policy regarding "Acts of God" and the allowability of re-weatherizing damaged homes, the Minot WAP was able to go back and re-weatherize flood-affected housing. However, many units could not be re-weatherized because tests indicated that remaining moisture levels were too high for successful re-weatherization. This precautionary measure resulted in the agency's having to "walk away" from many units. Three-quarters of the houses in the valley also had basements into which sewage had backed up, so the agency had to walk away from those as well. 


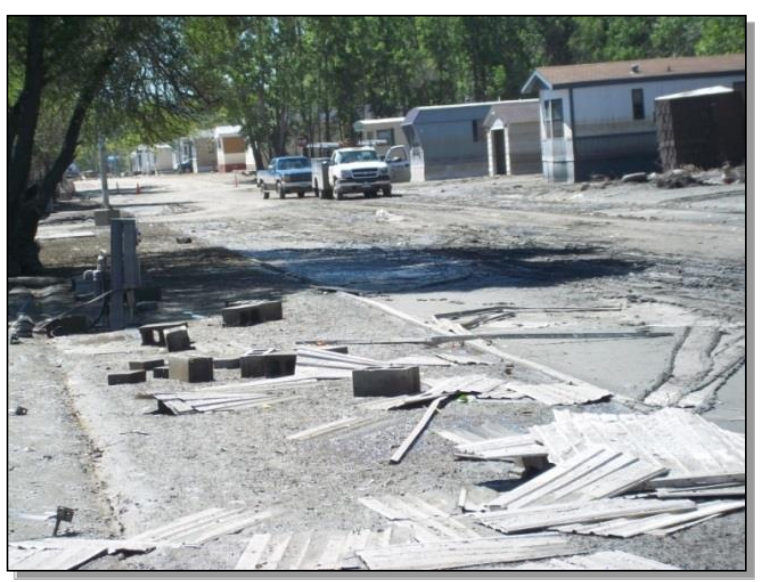

Fig. 15.11. Minot housing stock after the flood

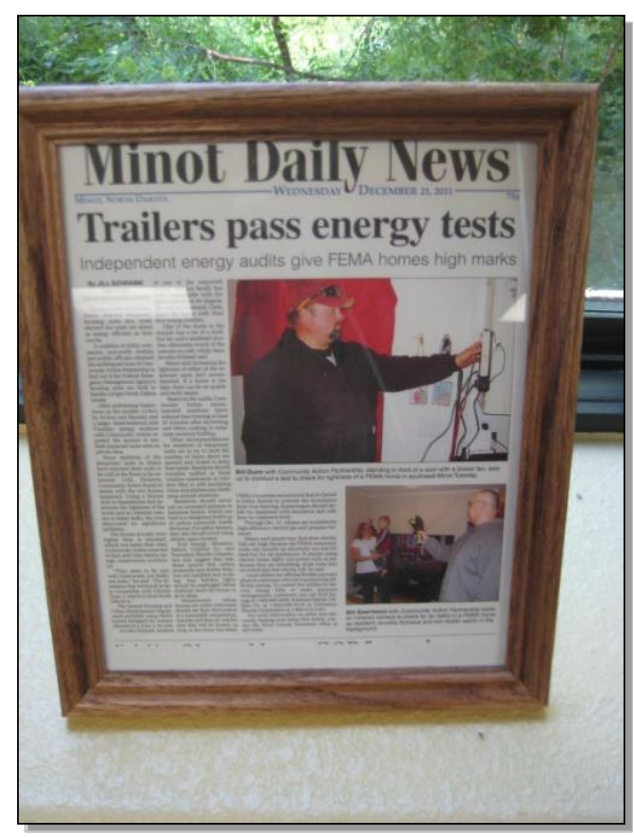

Fig. 15.12. Auditing FEMA Trailers

Ultimately, many of the units that had been previously weatherized were destroyed or damaged by the flood. Many homes had to be torn down. One crewmember stated, "It is disheartening to see hard (weatherization) work destroyed like that." Another commented that the homes being knocked down and or cleaned up resulted in hazardous materials such as "lead, asbestos, and vermiculite flying through the air."

In addition to the usual weatherization production, the CAP-Minot Region was asked by the city to investigate complaints of high electricity bills from flood victims living in FEMA trailers. The Minot crew was asked to conduct energy audits on the trailers. The infrared cameras revealed that the homes were adequately weatherized, but the trailers (See Figure 15.12) were fueled entirely by electricity, which was new to these Minot residents used to homes heated with natural gas. ${ }^{44}$

Driving through Minot one year post flood, its impact is still observable to the site visit team as families continue to rebuild and rehab their homes. The implications for CAP-Minot Region's program are felt as they continue to seek out eligible homes and households in need of their weatherization services.

\subsection{FRACKING AT THE BAKKEN SHALE OIL FIELD}

Since June of 2011, Minot has changed both from the flooding and from oil fracking. To the west of Minot is Williston, ND, host to a hub of oil wells and second in oil production in the US (after Texas). The Bakken Shale Oil field is producing over 800,000 barrels of oil a day in North Dakota alone. ${ }^{45}$ Over 41,000 workers were hired in North Dakota between 2008 and 2012, resulting in the lowest unemployment rate in the country. ${ }^{46}$ This employment opportunity has resulted in workers being flown in from all over the country and seeking temporary housing. Hotels are booked up, and rental properties have increased rates in response to the demand. It is the position of many of the WAP agency staff that

\footnotetext{
${ }^{44} \mathrm{http}: / /$ www.minotdailynews.com/page/content.detail/id/561470.html

$45 \mathrm{http}: / /$ oilshalegas.com/bakkenshale.html http://oilshalegas.com/bakkenshale.html

${ }^{46} \mathrm{http}: / / \mathrm{www} . c a r e 2 . c o m / c a u s e s /$ shale-oil-boom-in-north-dakota-is-impacting-native-americans-hard.html
} 
this has created an affordable housing crisis for permanent residents of Minot who may have been displaced by the flood but cannot afford the increase in rent in their local community.

Despite plenty of high-paying work associated with fracking, CAP-Minot Region weatherization crewmembers have remained. When the weatherization staff was asked why they continue to stay with CAP-Minot Region, one crew member stated, "Seems like you're doing good saving people money and saving tax payer money."

\subsection{SUGGESTIONS FOR WAP IMPROVEMENT FROM CREW AND CREW FOREMEN}

Although there was consensus amongst the group that the ARRA funding should have been spread out over many more years, it was also agreed that the increase of the average unit cost from $\$ 3250$ to $\$ 6500$ has been effective in creating a more energy-efficient housing stock. Because of this, they also propose getting rid of the Rule of ' $94^{47}$ as "You couldn't do certain things to a certain housing stock back then and now you can, so that house is not complete." It was also stated that if they could choose an innovative technology for their climate or housing stock to test they would install geothermal heat pumps. Expertise in this technology might assist with marketing efforts if the agency does venture into the fee-for-service work as many other WAP agencies have done across the country. This group anticipated that with more people entering the moderate-high income bracket in their service territory the agency may see an increase in demand in the private sector home energy retrofit field.

\section{Suggestions for the adoption of ASHRAE 62.2 from Crew and Crew Foremen}

At the time of this Case Study, the ND State Plan had not yet been approved. In it they proposed "using the old standard for ventilation and will use ASHRAE 62.2 only when needed." The crew thinks ASHRAE 62.2 is a good standard for new houses built too tight. The weatherization staff reported installing ventilation if there is evidence of a problem, but...

"If the problem is just not there, what's the point? If you run ASHRAE calculations you will put ventilation systems in 85 percent of homes and you will see impact on households with the high electricity rates in Minot. And funding wise it's a nightmare without a lot a benefit. It's simple. If you have 2 continuous fans running, the electric bill will go up."

They have done their own indoor air quality testing on VOCs and humidity and are willing to do more. Their primary point is: "If DOE is going to mandate something, we want to know why. Where is the data? What is it telling us?" They want justification for what they are being directed to do.

\footnotetext{
${ }^{47}$ Households may only receive weatherization services one time unless a change in technology proves cost effective enough to justify reweatherization or the house was weatherized before 1994; http://www.communityservices.nd.gov/energy/weatherizationassistance/http://www.communityservices.nd.gov/energy/weatherization-assistance/
} 


\subsection{INTERVIEW WITH CAP-MINOT REGION EXECUTIVE DIRECTOR WILLY SODERHOLM}

To Willy Soderholm, the Executive Director of CAP-Minot Region, WAP makes sense based on the money savings you get in return for the money invested. The families can then use that money for other things. He insisted that not all programs will see that return; "But with this one you do." He believes it's one of those programs that can help get people out of poverty, so he does not understand why the Program does not generate more support. He says that the job of the Community Action Agency is to take somebody in poverty to the point of self-sufficiency (See Figure 15.13). Whether or not they are in poverty as a fault of their own, new poverty as a result of the current economy, or from generational poverty, the CAP sees itself as providing more of a hand up than a hand out. The money saved (from weatherization) can assist with structural needs required for work and education. Simply put, it is a good investment.

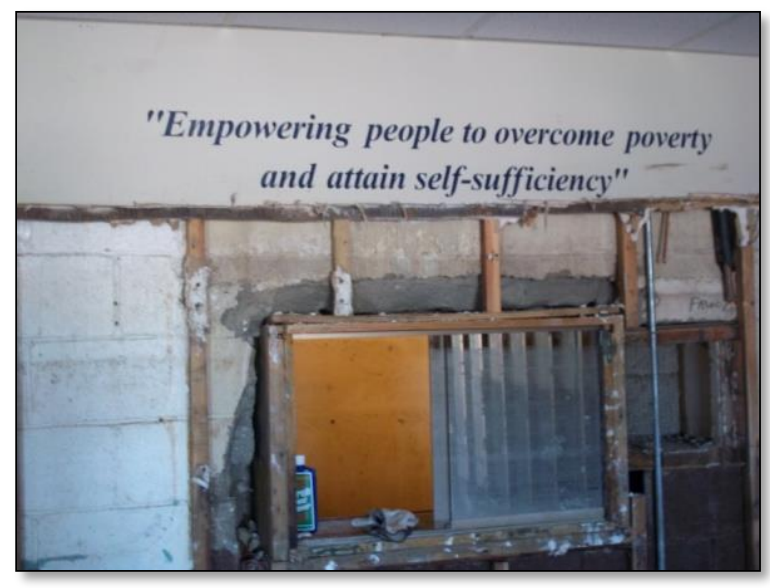

Fig. 15.13 The mission of the agency survives the flood

Ed Soderholm believes the future of the Program relies on securing leveraged funding and, more specifically, state funding. With the shift in demographics from the oil fracking boom and the flood, he proposes a new structure for eligibility and payment with a graduated scale dependent on income:

- free program to low and moderate income households to meet needs of community population;

- a graduated scale for payment for higher income households while taking into account cost of living increases and rent increases in Minot; and

- before clients receive fuel assistance, it should be required that they have their homes audited and weatherized. 


\section{LINDSAY PARK - LONG ISLAND CITY, NEW YORK}

Lindsay Park in Brooklyn, NY is a massive recently weatherized housing cooperative that includes seven large multifamily buildings and 2,702 apartments (See Figure 16.1).

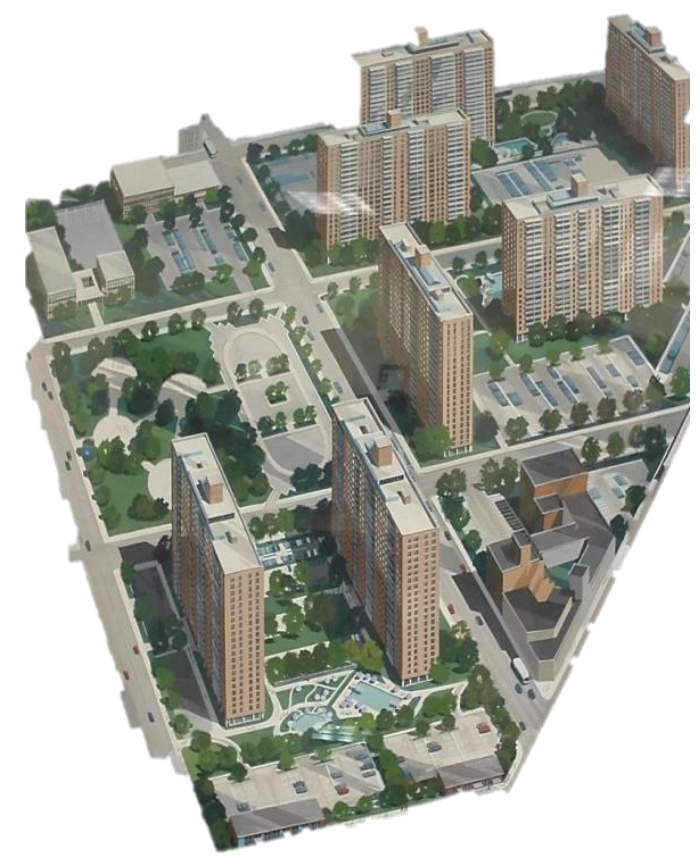

Fig. 16.1. Rendering of Lindsay Park Housing Corporation

Weatherization had been on the board's agenda for many years; new windows were particularly needed. However, multifamily weatherization for a project the size of Lindsay Park is extremely complicated due to the number of stakeholders in the complex. To successfully pull off a project of this magnitude, tremendous amounts of planning, coordination, leadership, trust-building, and cooperation are required.

ORNL conducted a residing shareholder debriefing at Lindsay Park in February 2012, hosted by the Community Environmental Center (CEC) as they were the turn-key agency for this weatherization project $^{48}$. It was immediately apparent that the leadership for this project came from a single indefatigable individual, Cora Nix-Austin, along with the support of several other hardworking stakeholders (all pictured in Figure 16.2). To get the 100 percent buy-in that was necessary from all involved, Nix-Austin, a familiar face in the community, personally knocked on all 2,702 doors to enlist the cooperation and support of every household in the complex.

Innumerable strategic planning sessions were held in order to establish how to organize, coordinate, lead, and evaluate the process; the time involved spanned about three years. Weatherization on the first building began in May 2011 (See Figure 16.3); however, asbestos was found in the existing window caulking, resulting in a temporary halt in production and fears mounted that the cost would skyrocket. It

\footnotetext{
${ }^{48}$ The Lindsay Park property was large enough that it required three agencies to handle the project. Community Environmental Center (CEC) in Long Island City was the turn-key agency with the assistance of Sunset Park and Opportunity Development Association (known as the ODA Community Development Corporation).
} 
was eventually established that a partial abatement could be an option if a waiver was approved and assurances were made that all units would be air-tested for asbestos before residents would return to their units. An on-site lab for air sample testing with decontamination chambers and showers was set up.

The actual weatherization work, in the end, was said to have "resembled a smooth running military operation" and was completed in only five months. Two floors (36 apartments) were completed per day without fail. An amazing feat and a story worthy of its own chapter

The scope of work for the Lindsay Park project apartments included the following:

- windows were replaced

- $\quad$ pipe were insulated

- ventilation duct screens were installed

- hallway and outer area lighting systems

- smoke alarms were installed and

- refrigerators were replaced for those who met income-eligibility requirements.

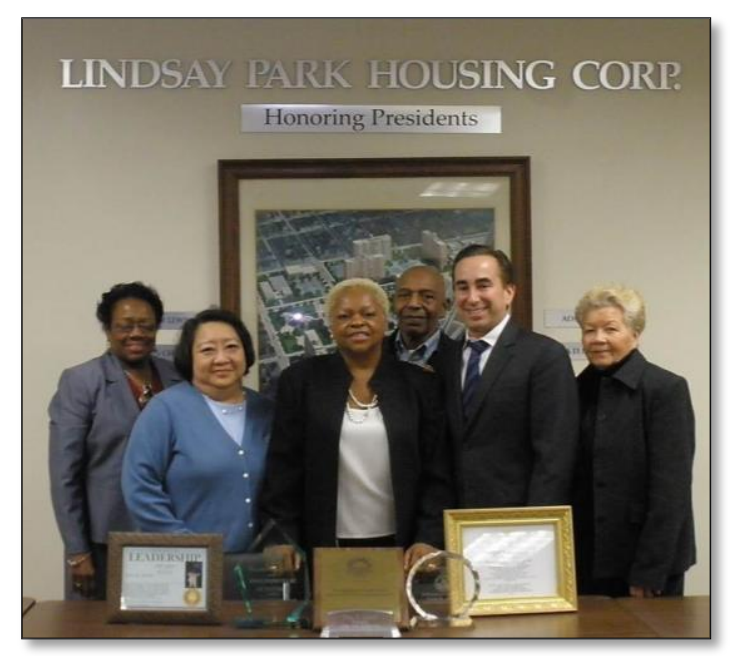

Fig. 16.2. Board of Directors with Cora Dix-Austin in the center and Thelma Arceo of the Community Environmental Center on her right.

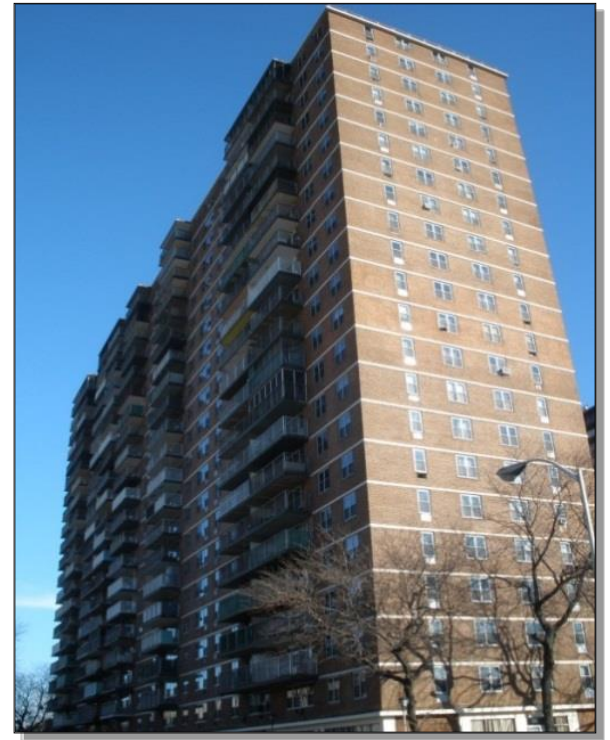

Fig. 16.3. One of seven buildings within Lindsay Park. 


\section{OBSERVATIONS}

\subsection{LOCAL WEATHERIZATION OPERATIONAL PHILOSOPHIES}

The material presented above and found in the case studies themselves depicts a program that is implemented in many manners at the local level by a very diverse set of local agencies. There is no one best staffing model (e.g., all in-house crews vs. all contractor crews) for a weatherization agency; it was found that every agency works hard to shape itself to best operate within its local context. In addition, it was found that various other aspects of agencies' operational models are quite diverse, for example with respect to the auditing tools used by an agency (computer vs. priority lists), the housing stock that it services (single-family, mobile home, or large multifamily), and the typical weatherization measures it installs (wall and ceiling insulation in cold climates like Colorado vs. rooftop solar water heaters in hot and sunny climates like Puerto Rico) (Section 2.0).

Instead of continuing to describe differences among programs, the purpose of this section of the report is to discuss the commonalities among the programs. These commonalities provide the foundation upon which successful programs flourish regardless of their distinct characteristics. The observations presented below are motivated and organized around important themes put forth by Peter Drucker in his seminal book, Managing the Nonprofit Organization: Principles and Practices. Drucker outlines several general categories in which successful nonprofit organizations excel: mission, commitment, respect, quality, innovation, and resilience.

Mission - All of the agencies visited as part of the retrospective evaluation have a strong sense of mission. However, the philosophies underlying those missions vary. For example, the Lewiston agency's mission is stenciled on its trucks: "We envision a community where: All people have sufficient money, relationships and meaning in their lives to thrive," emphasizing a sense of community (Section 4.0). CVCAC (Section 9.0) bills itself as the champion of weatherization. Regardless of the mission statements, or even each agency's understanding of what the larger view of its work is, the work of weatherization infuses every day's shared effort.

Commitment - In agency after agency, weatherization staff were found to be deeply committed to their jobs, and the agencies were, in turn, strongly committed to and supportive of their staff members. Clear evidence of this commitment was seen in the fact that a substantial majority of the core weatherization staff at all of the agencies has been at their jobs for decades. In all agencies, many thank-you letters were posted on bulletin boards expressing the appreciation of the clients toward the weatherization agencies and staff. Despite being able to provide only relatively low wages to their staffs, agencies work hard to provide such benefits as they can, and a collegial and comfortable working environment was characteristic of the agencies we observed.

The agencies were found to be very committed to their local communities as well. In discussions with the agencies, their concerns about community economic development, job training, and community stability were repeatedly expressed. Weatherization agencies often provide individuals with new career paths, give troubled youth second chances, and give local contractors the training needed to perform home retrofitting work beyond the immediate low-income weatherization.

In another example, the historic flood faced by the Minot agency (Section 15.0) challenged it to respond to the community's needs while staff was also trying to take care of their own flooded homes and maintain program services. Showing a similar spirit of helping neighbors, the SDC staff regularly volunteer their time to causes and activities that range far beyond day-to-day weatherization. It is not uncommon for these weatherization staff members to continue helping clients in their off hours, to 
prepare their homes for winter, for example. Personal commitment was found to be a defining characteristic of the weatherization network.

Respect - The organizational cultures witnessed were infused with respect for the clients served by the weatherization agencies. Weatherization personnel are acutely cognizant that there are many paths into poverty and that there are many barriers to rising out of poverty. Many of the homes they work with are in poor physical condition, and many households struggle to survive from day-to-day. The case study team, as well as social scientists employed through our Field Process Study, observed weatherization staff interactions with clients in hundreds of households. Clients and household members were uniformly treated with respect. For example, auditors are the first personnel to visit a home. We saw none who were judgmental or condescending; in fact, we were told repeatedly that those auditors who express disrespect toward the clients quickly leave the field or are encouraged to leave. The crews were respectful of household property, as well, cleaning up after the completion of the work. The hundreds of grateful letters sent to agencies by clients attest to the respectful treatment given them.

It was also clear that agencies respect their staff; this can be seen in how staff is empowered in various ways; auditors are empowered to develop weatherization job plans that will best meet the needs of households. They also deal with challenging home construction, and work both within budget constraints and with the opportunities afforded by leveraged funding. In most cases, the crew chiefs are empowered to revise job plans in the field when complicating conditions in the homes are revealed. The crew members, too, are trusted to do their work and empowered to make appropriate decisions. New crewmembers receive active management and mentoring, but veteran crews and crewmembers, upon entering a home on the first day of the job, quickly fan out through the house to work on their assignments without having to be micro-managed.

Quality - The weatherization agencies' sense of their mission, their commitment to their work and staffs, and the mutual respect given their employers combine to facilitate a culture of high-quality work. We witnessed a great deal of pride in the quality of agency employees' work among the long-term weatherization auditors, crew chiefs, and crew members.

WAP policy requires agencies to inspect all homes post-weatherization and for states to inspect a sampling of weatherized homes. We found that agencies are careful to assign auditing (preweatherization) and inspection (post-weatherization) tasks to different individuals in order to avoid any perception of conflict of interest.

A plethora of training opportunities, mentoring, and on-the-job training are available to support high quality work. We visited three organizations with their own state-of-the-art weatherization training facilities: Opportunity Council (Section 8.0), COAD (Section 10.0) and AEA (Section 13.0).

Innovation - Because they are constantly dealing with unforeseen situations as they enter a wide variety of homes in a wide variety of conditions, agencies need to be both innovative and creative, technically and organizationally, to deal with these situations. Over the longer term, several agencies have developed innovative approaches to and techniques for weatherizing homes (such as the mobile home "burrito" developed by Housing Resources of Western Colorado) (Section 3.0). Great pride is taken in innovations related to outfitting and packing-up the trucks the agencies take to job sites. St. Johns Housing Partnership (Section 11.0) is experimenting with new air-conditioning technology, and the Association for Energy Affordability has launched a distance-learning program. These programs highlight the energy and creativity that many agencies are bringing to the field at large and to their jobs in particular.

Organizational innovation and creativity are also brought to bear in "braiding" or combining leveraged funds to meet client needs. Creativity and innovation underpinned the ambitious plans made by COAD 
(Section 10.0) to weatherize the entire town of Murray City, Ohio, an approach both bold and successful. ${ }^{49}$ Agencies are also exploring innovative approaches to synthesizing program services and cross-program referrals. Some are experimenting with fee-for-service programs. The diversity of program operational models is a strong indicator of the innovation and creativity found within the national weatherization network.

Resilience - The agencies we visited exhibit the characteristic described by Drucker as resilience. That is, they find ways to survive year after year despite constrained and uncertain budgets, uncertainty about when funds will be available for expenditure, and often frustrating, confusing, and duplicative regulatory requirements. Many agencies were founded during the Johnson Administration and have been operating weatherization programs since the late 1970s. They have survived because they have built strong relationships with their key supporters - state weatherization offices, other state offices, utility companies, other community organizations, and multifamily building owners and because their management practices have adapted to fit changing circumstances.

The ARRA period's relatively rapid ramping-up and ramping-down periods tested the weatherization agencies. The case study team visited several agencies during the ARRA period's ramp-up and rampdown stages. During the ramp-up, agency managers were under an enormous amount of stress to grow their staffs and meet production numbers. An element of the ARRA legislation, the Davis-Bacon payscale requirements, at first delayed production and then produced numerous reporting difficulties. However, the agencies we visited persevered, largely without complaints, despite difficulties and the increased oversight implemented under ARRA.

As ARRA approached its end, the agencies needed to shrink, not just to pre-ARRA levels, but to even lower levels of federal weatherization funding. In response, agencies have been forced to lay off staff and crew members; in fact, many of the individuals interviewed during our case-study visits no longer work at their agencies. Unfortunately, the number of homes that the agencies can serve has been drastically reduced, hitting hardest the people who had been hired during the ramp-up and who, in fact, represent those whom the agencies strive to serve through weatherization itself-low-income working people. It is unfortunate that that population has been doubly hit by the reductions in ARRA funding.

Qualifications - We believe our observations confirm that weatherization agencies are on-mission, committed, respectful, innovative, resilient, and that their work is of high quality. Further, we believe these conclusions can be generalized to the broader national network of low-income weatherization service providers. While our set of cases represents agencies with very different operational models, which operate in a range of states, settings, and climates, and which deal with a range of housing types, it should be pointed out that other reports prepared as part of the retrospective evaluation suggest that opportunities still exist to improve the quality of weatherization work nationwide, increase leveraging resources, and increase the achievable energy savings and cost-effectiveness of the Program.

\subsection{OTHER OBSERVATIONS AND CONCLUSIONS}

This sub-section contains additional observations about what was witnessed in the field and with respect to WAP moving forward.

\footnotetext{
49 The 2013 March/April issue of Home Energy Magazine has an article (the cover story) on the weatherization of Murray City entitled, Revitalizing the Rural Community. Hocking-Athens-Perry Community Action Program (HAPCAP) is featured as a community action agency that had the capacity and tenacity to make the project a success. http://www.homeenergy.org/show/article/nav/issues/magazine/129/id/1853http://www.homeenergy.org/show/article /nav/issues/magazine/129/id/1853
} 
There are too many local conditions that mediate against a one-size fits all approach. For example, programs that weatherize relatively few units per year cannot afford full-time, year round in-house crews. Some local economic situations are more conducive to contracting than others (See the HELP case). The typical suite of measures installed may also lead a program to choose an in-house model versus a contracting model (e.g., Housing Resources focuses on using in-house staff to blow insulation whereas the Puerto Rico model relied on contractors to deliver and install major measures like solar water heaters).

The national weatherization network does not get the credit it deserves for dealing with the diversity of conditions it faces in the field. It was mentioned above that the local programs need to adjust to different climates, housing stock, fuel types, and demographics. They also need to adapt to their particular leveraging opportunities, be they related to healthy homes (Opportunity Council) or weatherizing entire communities (COAD).

Energy education was seen to be quite effective as it relates to its impact on energy consumption at a household level. The best models witnessed included a separate energy educator who either accompanied the auditor (Lewiston) or visited the home pre-audit (Opportunity Council). The client agreements that the CAHRA program uses also seem to work well. Auditors and crew members can provide energy education if given the time. This time was in short supply during the ARRA period. The intense focus on production limited the amount of time any agency staff could spend with households.

After witnessing how programs ramped up and then down again during the ARRA period and listening to their travails during this period of time, one can conclude that more appreciation is due the national weatherization network for how it dealt with the ARRA funding and Davis-Bacon regulations.

Even with the added ARRA funding, the number of homes eligible for weatherization is far greater than available resources can serve. Many agencies have long waiting lists; many others do not advertise their programs in an attempt to keep waiting lists short. When asked, most estimated that it would take many decades to serve the number of eligible homes given current funding.

It was observed that increased funding during the ARRA period allowed DOE to pass more money down to the states and agencies for training and technical assistance T\&TA. This additional money afforded by a larger program actually led to better training and better quality assurance in the field.

The larger program allowed DOE to experiment with the installation of renewable energy and energy efficient measures not currently allowed by standard program rules. The several agencies visited that received SERC grants (e.g., HELP, Opportunity Council) had no problems incorporating these new measures into their programs.

A larger and more integrated program could help more households in number and households not currently served by the program. Falling into the latter category are households that agencies walk-way from because they are in such bad shape. It is an ironic observation that many of the truly worse-off households cannot be served by WAP for this reason. A program integrated with home repair and renovation resources from other federal agencies could accommodate more of these households. 
APPENDIX A. PARTNERSHIP AGREEMENT SIGNED BY ALL CAHRA WEATHERIZATION CLIENTS 



\title{
APPENDIX A. PARTNERSHIP AGREEMENT SIGNED BY ALL CAHRA WEATHERIZATION CLIENTS
}

\author{
Weatherization and Final inspection and Partnership Agreement
}

I certify that the weatherization work explained to me has, to the best of my knowledge, been completed and that I am satisfied with the workmanship. I also acknowledge the receipt of client education materials. Upon signing this agreement, I acknowledge that I may no longer be eligible to weatherization services at this residence. I release Community Action Human Resources Agency and its employees from all further responsibilities for the completed improvements providing problems with poor quality or material defect are not discovered within one year from today's date. If a smoke or carbon monoxide detector has been installed, I assume all responsibility regarding battery replacement and testing as recommended by the manufacturer.

\section{In return for receiving weatherization services I aqree to do the following:}

a Read the client education materials left by the agency staff.

a Have the furnace filters cleaned or replaced once a month.

a Where possible keep the thermostat at 68 degrees in the winter and at 78 degrees in the summer.

a Where possible, turn down the thermostat 10 or more degrees at night or when away from the home for more than 2 hours.

a During the winter, open all south facing window coverings on sunny days and close all windows coverings at night to hold in the heat.

u Make sure heating/cooling vents and registers are not blocked.

a Have the coils on refrigerators and freezers cleaned at least once a year.

․ Use kitchen and bathroom fans to reduce excessive moisture buildup

a In the summer use natural ventilation and window shading to help cool the home.

a Effectively use kitchen and other household appliances to save money

a Be efficient in using hot water.

Weatherization Recipient

$$
\text { Date }
$$

I certify that all work ordered on the energy audit inspection sheets and to be reported on the Building Weatherization Report has been properly completed. A proper and accurate energy audit has been performed which identified all applicable weatherization measures and the final inspection was completed by someone who did not do any weatherization work on the home. Reasonable efforts have been made to identify possible or obvious hazards to the health and safety of the occupants and alternatives to minimize those potential hazards have been explained to the applicant. Any variations from the Weatherization Guidelines are to be documented in the client file or noted on the back of this form 